Historic, Archive Document

Do not assume content reflects current scientific knowledge, policies, or practices. 



\section{Vicksburg Seed Company 1925 Catalogue}

\section{ESTEEMED FRIENDS AND CUSTOMERS:}

In offering this, our 1925 annual catalog, we have endeavored to list only such vegetable, flower and farm seeds of proven standard varieties.

Our prices are consistant with the quality of seeds we offer as we have secured them from the best known growers in this country and Europe.

The Vicksburg Seed Company is managed by men who have had many' years of experience in all branches of the seed business and know the needs of our Southern farmers.

It is our policy to sell only quality seeds and to give a service as good as the best; all orders, both large and small, will be given our careful and prompt attention; all we ask is that you give us a trial and we feel sure that you will become one of our friends and patrons.

Sincerely yours,

\section{VICKSBURG SEED COMPANY,}

\section{J. F. Haid, President.}

\section{GENERAL INSTRUCTIONS TO CUSTOMERS}

PRICES AND TERMS-The prices we quote on Vege. table Seeds will hold good as long as stock last. The prices on Grass Seeds, Grains and all Farm Seeds are prices on Grass Seeds, Grains and all Farm seeds are As far as possible we will fill in full all orders for Seed. that are cucted subject to variation in price, but if market vilue wiil not permit this, we will send all that money remitted will pay for.

Notice carefully the prices. Be sure to know whether we or you are to pay the carrying charges, and bear in mind that we do not pay the express or freight charges on pecks or bushels, nor on any Tools, Bulbs, Grass Seeds, Field Seeds or Fertilizers, except where we so state on the pages where the goods are priced.

Please Send Money With the Order sufficient to cover the whole bill, and remit by express money order or registered letter. Checks covering payment of goods must include 10 cents for collecting them. You will avoid delay by remitting by express or postoffice noney, or'der. We decline sending goods "Collect On Delivery" anless remit

DEIIVFRY GUARANTEED-We will guarantee the safe arrival of all goods by Parcel Post. All packages lost will be replaced promptly and without cost to you.
NON-WARRANTY-The Vicksburg Seed Co. does not give, and their agents and employees are forbidden to give any warranty, express or implied, as to description, quality, productiveness, or any other matter of any seeds, bulbs, plants, etc., they send out and they will not be in any way responsible for the crop. If the purchaser does not accept the goods on these terms, they are to be returned at once, and if the money has been paid for them, it will be refunded. NO RESPONSIBLE SEEDSMAN GIVES ANY WARRANTY.

POSTAGE-We pay postage on all Seeds quoted by the package, ounce, quarter-pound and pound, and upon all goods quoted in our catalog where it says parcel post paid.

MARKRT GARDENFRS and Those Using Large Quantities of Seed should send us a list of their requirements. Prices will be furnished promptly, and we can frequently make a substantial reduction on large orders.

ERRORS IN FIIIING ORDERS-While we exercise the greatest care in filling orders, mistakes sometimes occur, in which event they will be cheerfully and prompt. iy rectified by us. Keep a duplicate copy of all orders sent us until you have received the seeds.

\section{N E X}

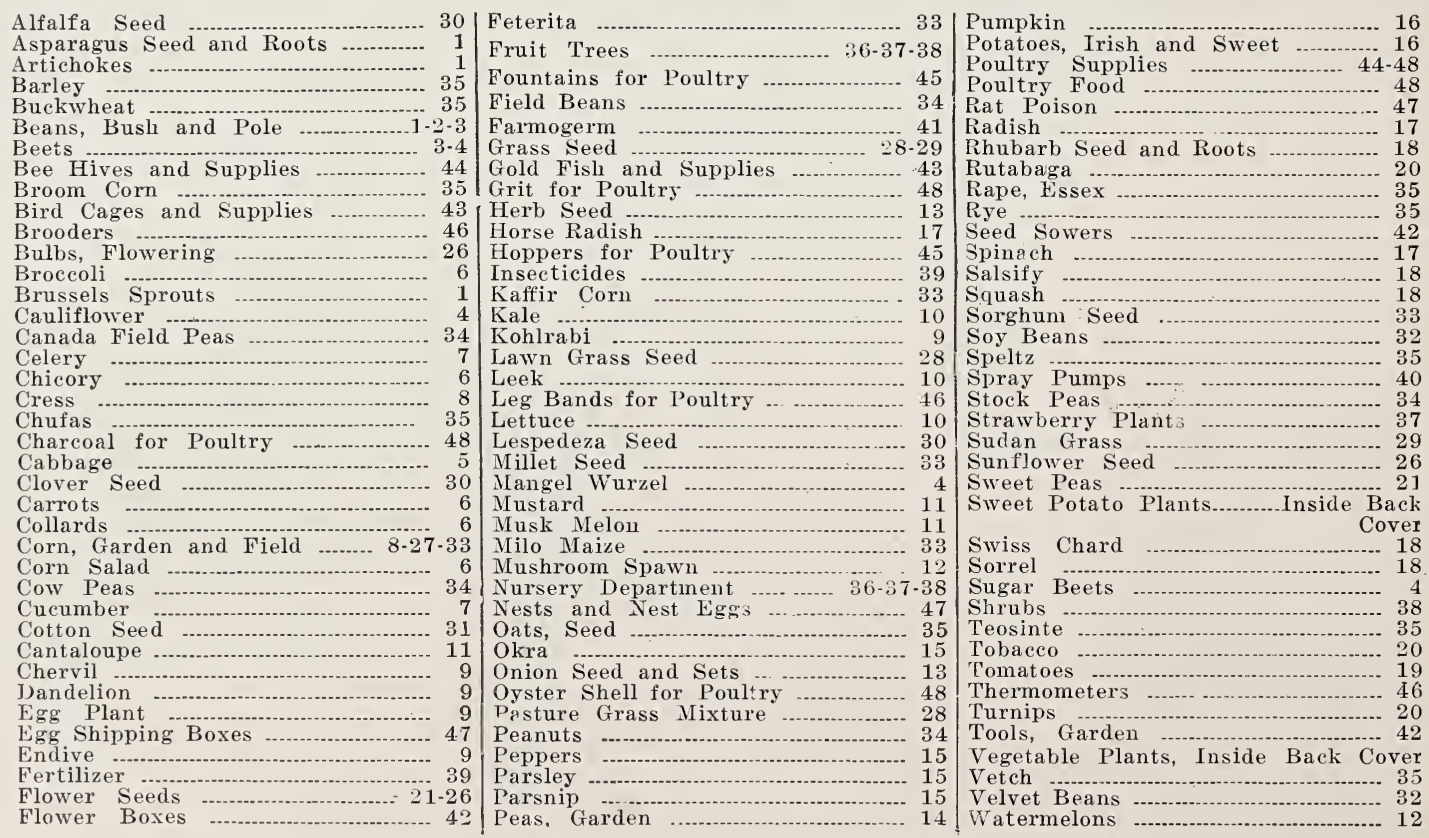




\section{VICKSBURG SEED CO.'S PRICE LIST}

\section{JANUARY ist, 1925}

VICKSBURG, MISS.

Prices quoted on this list are present valuıs, subject to change without notice, net cash, and are F. O. B. Vicksburg, Miss., sacks included, purchaser paying all freight or express charges, and if to be sent by parcel post sufficient postage must be added to the following prices. If prices are lower, refund will be madz; if higher we will advise.

BEANS, BUSH-Green Pod. (bu. 60 lbs.)

Black Valentine ..-

$\$ 1.85 \$ 3.25$ Q $\$ 11.75$

Burpee's Stringless Green Pod....... $1.85 \quad 3.25 \quad 11.75$

Giant Stringless Green Pod ........... $1.85 \quad 3.25 \quad 12.25$

Extra Early Red Valentine................... $1.75 \quad 3.00 \quad 11.50$

Round Yellow Six Weeks.................. $1.75 \quad 3.00 \quad 11.50$

Tennesee Green Pod............................ $1.85 \quad 3.25 \quad 12.25$

BEANS, BUSH-Wax Pod.

$$
\text { (bu. } 60 \text { lbs.) }
$$

Currie Rust Proof Wax

$\begin{array}{lll}1.75 & 3.00 & 11.75\end{array}$

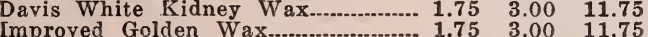

Wardwell's Kidney Wax-...-...-...-...... $1.75 \quad 3.00 \quad 11.75$

BEANS, POLE OR RUNNING-

(bu. 60 lbs.)

White Creaseback

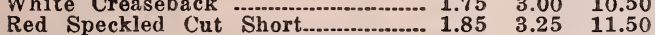

Scotia or Striped Creaseback.......... 1.85 $3.25 \quad 12.50$

McCaslan Pole ................................ $2.25 \quad 3.75$

BEANS, POLE LIMA-(bu. 60 lbs.) 4 Qts. Pk. Bu.

Carolina Sieve or Small Lima.........\$2.25 $\$ 4.25 \$ 15.50$

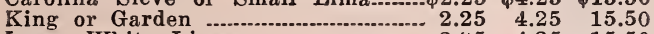

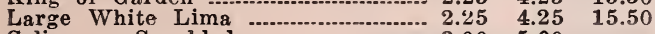

Calico or Speckled................................ $3.00 \quad 5.00$

BEANS, BUSH LIMA-(bu. 60 lbs.) 4 Qts. Pk. Bu.

Henderson's Bush ............................ \$2.25 $\$ 4.25 \$ 15.50$

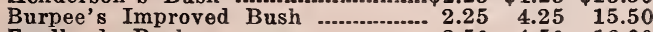

Fordhook Bush ............................. 2.50 $\quad \mathbf{4 . 5 0} \quad \mathbf{1 6 . 0 0}$

GORN, GARDEN 4 Qts. Pk. Bu.

Extra Early Adams (bu. 56 lbs.) ....\$ $.85 \$ 11.25 \$ 4.25$

Golden Bantam (bu. 45 lbs.)......... $90 \quad 1.50 \quad 5.00$

Improved Large Adams

Adams' Large Early (bu. 56 lbs.).. $\quad .85 \quad 1.25 \quad 4.25$

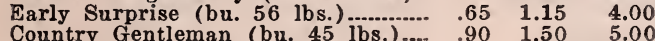

Mammoth or Large Sugar (bu.

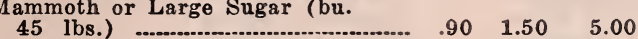

Stowell's Evergreen (bu. 45 lbs.).... $9.90 \quad \mathbf{1 . 5 0} \quad \mathbf{5 . 0 0}$

ONION SETS-(bu. 32 lbs.) 4 Qts. Pk. Bu.

Yellow Danvers ............................. \$ .65 $\$ 1.25 \$ 4.50$

Dark Red Wethersfield .......................65

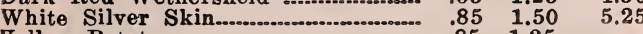

Yellow Potato

SEED POTATOES-(bu. 60 lbs.) Pk. Bu. 21/2 Bu.

Red Triumphs, Northern Grown...... $\$ .75 \$ 2.00 \$ 4.50$ Irish Cobbler ................................... $75 \quad 2.00 \$ 4.50$

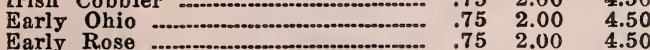
Lookout Mountain ................................. Write for Prices

SEED SWEET POTATOES-(bu, 45 lbs.)

Nancy Hall

Porto Rica Yam

Write for prices

Write for prices

\section{PEAS, GARDEN}

4 Qts. Pk. Bu.

American Wonder .... (bu. 56 lbs.) $\$ 1.75 \$ 3.00 \$ 11.00$ Alaska .......................(bu. 60 lbs.) $1.75 \quad 3.00 \quad 11.00$ Ameor, Large Alaska (bu. 60 lbs.) $1.75 \quad 3.00 \quad 11.00$ First and Best .........-(bu. $60 \mathrm{lbs}$ ) $1.75 \quad 3.00 \quad 11.00$ Gradus, or Prosperity (bu. 56 lbs.) $2.00 \quad 3.25 \quad 11.50$ $\begin{array}{lllll}\text { Champion of England ..(bu. } 56 \text { ib.) } & 1.75 & 3.00 & 10.75\end{array}$ White Marrowfat _.. (bu. 60 lbs.) $\quad 1.25 \quad 2.50 \quad 8.00$

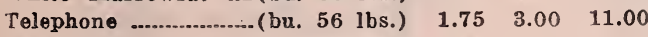
Laxatonia ….............(bu. 56 lbs.) $2.25 \quad 3.75 \quad 13.00$ Thomss Laxton ........ (bu. 56 lbs.) $2.00 \quad 3.50 \quad 12.00$
SEED CORN-White-(bu. 56 lbs.) Pk. Bu. $2 \frac{1}{2} \mathrm{Bu}$ Paymaster ….................................... $\$ 1.00 \quad \$ 3.50 \$ 8.50$

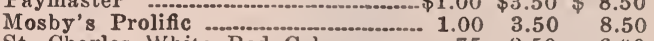

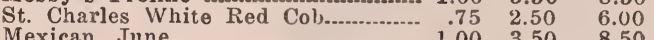

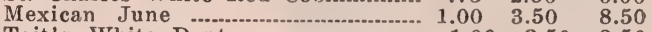

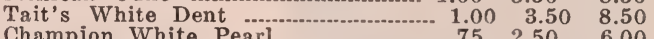

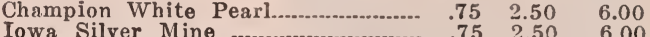

Tennessee Red Cob, White.................. $1.00 \quad 3.50 \quad 8.50$

Hickory King ........................................ $1.00 \quad 3.50 \quad 8.50$

SEED CORN-Yellow-(bu. $56 \mathrm{lbs}$ ) Pk. Bu. $2 \frac{1}{2} \mathrm{Bu}$.

Iowa Gold Mine $\quad \$ \quad 75 \$ 2.50 \$ 6.00$

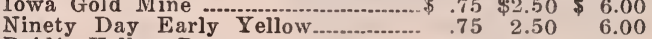

Reid's Yellow Dent .................................. $75 \quad 2.50 \quad 6.00$

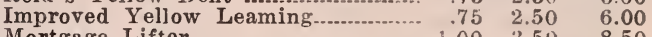

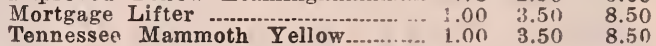

ENSILAGE, FODDER CORN-

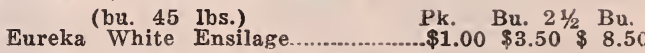

CLOVER SEED

Alfalfa, Dakota No. 12 ,

Fancy a................... (bu. 60 lbs.) $\$ 4.2516 .50 \$ 26.50$

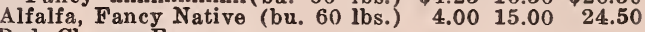

Red Clover, Fancy

Ohio ….............. (bu. 60 lbs.) $5.5021 .00 \quad 35.00$

Iammoth or Sapling

Clover ........................ (bu. 60 lbs.) $\quad 5.50 \quad 21.00 \quad 35.00$

Alsike Clover -...-...-....(bu. 60 lbs.) $\quad 4.00 \quad 16.00 \quad 27.00$

White Clover ................(bu. $60 \mathrm{lb}$.) $9.00 \quad \mathbf{3 6 . 0 0} 60.00$

$\begin{array}{lllll}\text { Crimson Clover ...........(bu. } 60 \text { lbs.) } & 2.25 & 7.20 & 12.00\end{array}$

Japan Clover

(Lespedeza Striata) …(25 lbs.) Write for pricen Melilotus (Hulled) ....(bu. 60 lbs.) $3.00 \quad 11.00 \quad 18.00$

Burr Clover (Burr) ....(bu. $10 \mathrm{lbs}$ ) $\quad r .75 \quad 15.00$

GRASS SEEDS

10-1b. 50-1b. 100-1b.

Sunny South Lawn Grass $\quad \$ 4.50 \quad 20.00 \$ 40.00$

Shady Spot Lawn Grass...................... $4.50 \quad 20.00 \quad 40.00$

Permanent Pasture Grass Mix.

ture ........................... (bu. 14 lbs.) $3.5017 .00 \quad 32.50$

Permanent Meadow Grass Mix-

ture -... (bu. 14 lbs.) $3.50 \quad 17.00 \quad 32.50$

Permanent Hog Pasture Mix.

$\begin{array}{lllll}\text { ture …....................... } 14 \text { lbs.) } 3.50 & 17.00 & 32.50\end{array}$

$\begin{array}{lllll}\text { Timothy and Alsike Mixture......... } & 2.50 & 8.50 & \mathbf{1 6 . 0 0}\end{array}$

Kentucky Blue Grass.. (bu. 14 ibs.) $4.50 \quad 20.00 \quad 39.00$

English Blue or Meadow Fescue

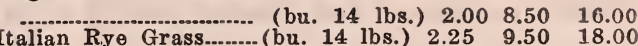
$\begin{array}{lllll} & \end{array}$ (bu. 14 lbs.) $2.25 \quad 9.50$ Orchard Grass .............(bu. 14 lbs.) $3.50 \quad 11.00 \quad 22.00$

Bermuda Grass ...... $6.00 \quad 30.00 \quad 55.00$

Red Top or Herds Grass, Fancy seed

$\begin{array}{lll}2.50 & 10.50 & 20.00\end{array}$

Tall Meadow Oat Grass (bu. 14 lbs.) $3.75 \quad 16.00 \quad 30.00$

Timothy ........................ (bu. 45 lbs.) $1.75 \quad 6.00 \quad 11.00$

Sudan Grass .................................... $1.50 \quad 5.00 \quad 9.50$

FIELD BEANS-(bu. 60 lbs.) Qts. Pk. Bu.

Velvet Beans, Early Bird Speckled_\$ $.75 \$ 1.25 \$ 4.50$

Velvet Beans, Bush______._. .90 i.50 5.50

Velvet Beans, Osceola__._........ $\quad .75 \quad 1.35 \quad 4.75$

Soy Beans, Mammoth Yellow......... $\quad .60 \quad 1.00 \quad 3.50$

Soy Beans, Biloxi.............................. .85 $\quad 1.25 \quad 4.75$

Soy Beans, Otootan ..................... 2.25 $3.50 \quad 12.00$

Soy Beans, Laredo...........................2. $2.25 \quad 3.50 \quad 12.50$

Page 48 


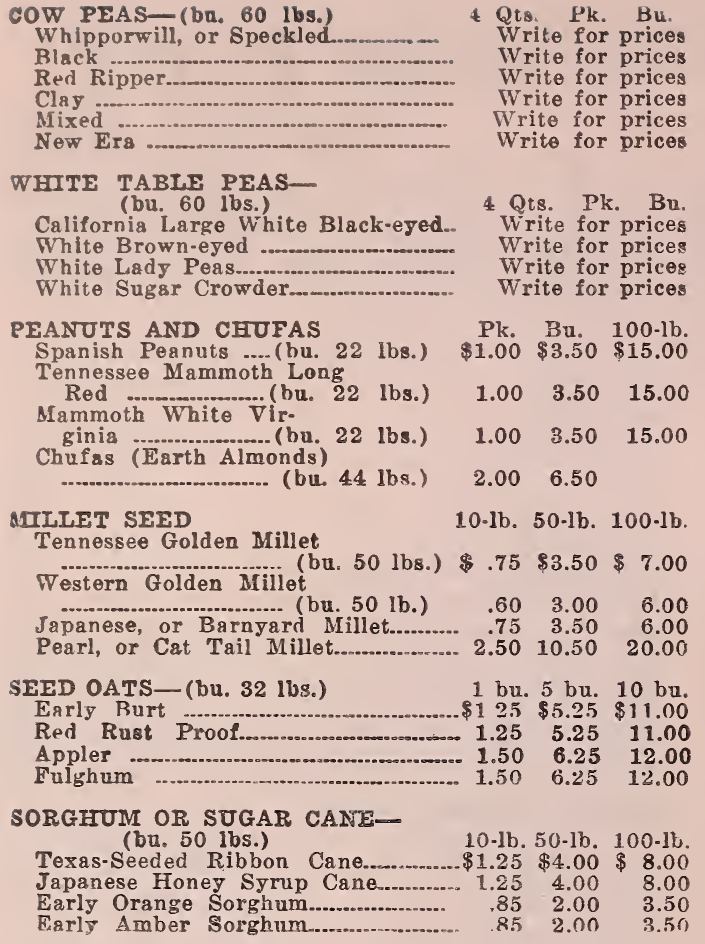

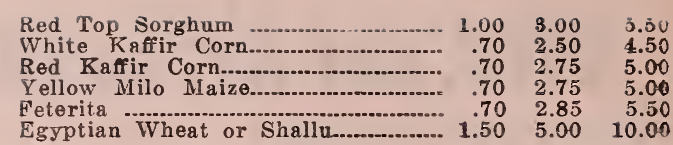

MISCELIANEOUS FARM SEEDS $1 \mathrm{lb}$ Pk. Bu Speltz or Emmer....... (bu. 40 lbs.) $\$ .10 \$ .85 \$ 3.00$ Beardless Barley............(bu. 48 lbs) $.15 \quad .90 \$ 2.00$ $\begin{array}{llrr}\text { Beardless Barley........... (bu. } 48 \text { lbs) } & .15 & .90 & 2.00 \\ \text { Japanese Buckwheat (bu. } 50 \text { lbs.) } & .15 & 1.00 & 3.50\end{array}$ $\begin{array}{llll}\text { Japanese Buckwheat (bu. } 50 \text { lbs.) } & .15 & 1.00 & 3.50 \\ \text { Silver Hull Buckwheat (bu. } 50 \text { lbs.) } & .15 & 1.00 & 3.75\end{array}$ Broom Corn Evergreen (bu. $46 \mathrm{lbs}$ ) $\quad .15 \quad 1.00 \quad 3.50$ Broom Corn, Dwarf (bu. 46 lbs.) $.15 \quad 1.00 \quad 3.75$ Teosinte ........................................... $\$$ 10-1b. $50-1 \mathrm{~b}$ $\begin{array}{llll}30 & 1.50 & 6.00\end{array}$ $\begin{array}{llll} & 35 & 2.75 & 11.00\end{array}$ Sunflower, Russian ...................... $\quad .20 \quad 1.75 \quad 7.50$ Rape, Dwari Essex............................ $.25 \quad 1.50 \quad 7.00$ COTTON SEED-(bu. 30 lbs.) 1 ba. 5 bu. 10 bu. Simpkins …....................................50 $7.00 \$ 13.50$ Half and Half................................. $1.50 \quad 7.00 \quad 13.50$ Wa nnamaker-Cleveland ..................... $1.50 \quad 7.00 \quad 13.50$

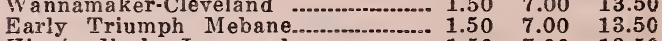
King's Early Improved ................... 1.50 $7.00 \quad 13.50$ Acala No. 5...................................... 2.00 $9.50 \quad 18.00$

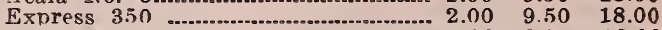
Delphos $6102 \ldots 2.00 \quad 9.50 \quad 18.00$

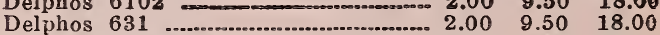

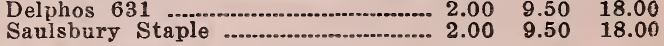

POULTRY FEEDS, ETC. 25-1b. 50-1b 100-1b. Red Comb Poultry Feed.............10 \$2.00 \$ 3.85 Red Comb Mash with Buttermilk.... 1.25 $2.25 \quad 4.25$ Red Comb Coarse Chick ............... 1.25 2.25 4.00 Red Comb Fine Chick ...................... 1.25 $2.25 \quad 4.25$ Red Comb Baby Chick Milk Mash.... 1.50 2.75 5.00 Red Comb Growing Mash ........... 1.40 2.65 4.75 Chamberlain's Perfect Chick Feed Write for prices ronkey's Buttermilk Starting Feed Write for pricea

\section{BIG DOLLAR COLLECTION}

Thirty packages of Assorted Seeds for only $\$ 1.00$. At regular prices they would cost you $\$ 1.75$ A complete Garden for only $\$ 1.00$, parcel post paid. One packet each of the following seeds:

Bush Beans, Greenpod.

Pole Beans, Kentucky: Wonder

English Peas, Alaska

Beet, Crosby's Egyptian

Cabbage, Early Flat Dutch

Collard, Georgia

Carrot, Improved Long Orange

Corn, Early Surprise

Cucumber, Long Green

Cabbage, Wakefield
Cantaloupe, Rocky Ford
Egg Plant, New York
Lettuce, Big Boston
Mustard, Giant Curled
Okra, White Velvet
Onion, Red Weathersfield
Pepper, Bell or Bull Nose
Parsnip, Hollow Crown
Parsley. Double Curled
Peas, Telephone

Pepper, Long Cay'enne

Radish, Scarlet White Tip

Radish, Long Scarlet

Spinach, Curled Savoy

Squash White Bush

Swiss Chard, Silver Beet

Tomato, Stone

Tomato, Acme

Turnip, Purple Top Globe

Watermelon, Halbert Honey

\section{TRIAL COLLECTION}

Twelve packets of best Garden Seed for only $25 \mathrm{c}$, postage paid. One packet each of the follow. ing va rieties:

Beets, Blood Turnip

Cabbage, Early Drumhead

Lettuce, Hubbard Market

Collard, True Southern
Cucumber, Long Green

Watermelon, Rattlesnake

Carrot, Danvers

Onion, Wethersfield
Mustard, Giant Curled

Radish, Scarlet Turnip

Squash, Early White Bush

Tomato, Early Detroit

\section{FLOWER SEED COLLECTION}

Twelve papers Assorted Flower Seeds for only 2ic, postage paid. One packet each of the follow ing va rieties:

Aster, China Mixed

Sweet Alyssum

Pink, China Mixed

Mignonette, Sweet
Verbena, Mixed

Pansy, Choice Mixed

Morning Glory

Zinnia, Mixed
Poppy, Mixed

Phlox, Mixed

Petunia, Single Mixed

Cosmos 


\section{ASPARAGUS SEEDS AND ROOTS}

One ounce will produce about 200 plants; or plant 40 feet of drill; ; pounds will plant an acre.

Sow early in spring 2 inches deep in rows of 18 inches apart When one or two years old transplant into permanent bed, in furrows 4 to 5 feet apart and 2 feet between the plants. Deep loamy soil, thoroughly cultivated and heavily manured, is required for permanent bed. Complete directions on request.

COLUMBIAN MAMMOTH WHITEA new and entirely distinct kind whose shoots are white and stay white as long as fit for use. Pkt., $5 \mathrm{c} ; 1$ oz., $10 \mathrm{c}$; oz., $15 \mathrm{c} ; 1 / 4$ lb., $25 \mathrm{c} ; 1$ lb., $75 \mathrm{c}$; parcel post paid.

PAIMETTO-A fine variety, very large, early and adapted to all climates. Pkt. $5 \mathrm{c} ; 1$ oz., $10 \mathrm{c} ; 2$ oz., $15 \mathrm{c}$; $1 / 4$ lb., $20 \mathrm{c}$; 1 ib., $60 \mathrm{c}$, postpaid.

PAIMETTO ASPARAGUS ROOTSA saving of 1 to 2 years is effected by planting roots. For private use or for marketing on a small scale, beds should be formed 5 feet wide, with 3 rows planted in each one in the middle and one on each side a foot from the edge; distance between the plants in the rows 9 inches. Price, parcel post paid, 2-year roots, doz., 40c; 50 for $\$ 1.25 ; 100$ for $\$ 2.40$.

Price by express, purchaser's expense, 2 -year roots, doz., 30c; 50 for $\$ 1.00$; 100 for $\$ 2.00$

\section{BRUSSELS SPROUTS}

One ounce will sow 200 feet of drill, or produce 2,000 plants.

Sow seed for plants in frames or open ground. Set plants in early spring, and for succession up to July, making rows 3 feet apart and having the plants stand $11 / 2$ to 2 feet apart in the row.

Brussels Sprouts are a very delicate vegetable, and deserves a more general cultivation than they receive. The plant belongs to the cabbage family, and should be grown and cultivated like cabbage. Very hardy; improved by frost.

DWARF IMPROVED - Bearing

large crop of small, solid, tender heads. Pkt., 10c; 1 oz., 30c; 2 oz., $60 \mathrm{c} ; 1 / 4 \mathrm{lb}$. $\$ 1.00$, postpaid.

\section{ARTICHOKE}

One ource will produce 500 plants; $1 / 4 \mathrm{lb}$. to the acre.

Seed should be sown in hotbeds early in February to get plants that will bear first year. Transplant to open ground in April, in deep, rich, sandy loam with plenty of well rotted manure.

IARGE GREEN GLOBE-PROduces heads like flowers, which are
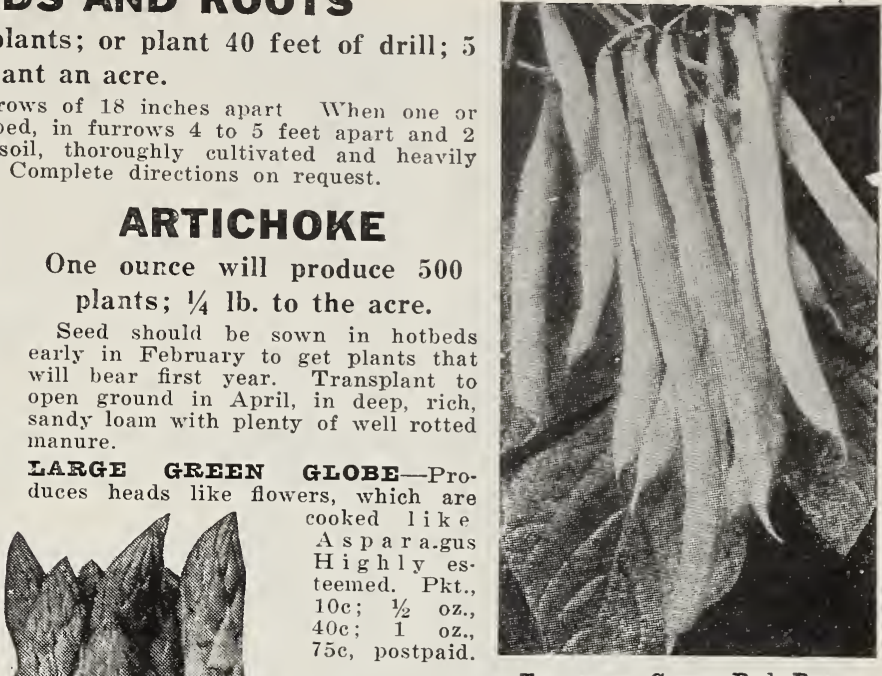

Tennessee Green Pod Beans

\section{BUSH BEANS} GREEN PODDED

One pound will plant 100 feet of drill.

Beans are somewhat tender, but it often pays to take some risks. Plant in warm. loamy soil at the beginning of settled, warm weather in spring, and at intervals for succession until September. Rows may be made 2 feet apart, and the Beans planted a few inches apart in the drills, or 3 or 4 beans in hills 6 to 8 inches apart. Cultivate and hoe frequently, al. ways, however, when the plants are perfectly dry. In hoeing draw the soil up towards the rows or plants. For string beans, gather the pods clean as soon as fit for use. The plants will remain all the longer in bearing.

BURPEE'S STRINGIESS (GREEN POD) - This new bean produces a vine similar to Palmetto Asparagus the Valentine. It is several days earlier than the best strain of Valentine. The pods are green and not so round as the Valentine and less curved. The pods are stringless-absolutely so. An excellent table bean. Pkt., 10c; $1 / 2$ lb., 20c; 1 lb., $40 \mathrm{c}$; 2 lbs., $75 \mathrm{c}$; 5 lbs., \$1.75, postpaid.

GIANT STRINGLESS GREEN POD BEANS-A very hardy, stocky vine; pods round, green in color and of exceptionally fine quality. Stringless throughout the entire length. About a week earlier than the Red Valentine and more prolific. Pkt., 10c; $1 / 2$ lb., 20c; 1 lb., 40c; 2 lbs., $75 \mathrm{c}$; 5 lbs., $\$ 1.75$, postpaid.

BLACK VAIENTINE-This excellent variety is a great improvement over the old standard Red Valentine, being one-third longer than that variety. with vods verfectly round and stringless and of excellent quality. It is also suitable for early planting, and is extremey hardy. It will withstand early and late frost. It is an excellent shipper, a large yielder and very handsome appearance. Pkt., 10c; 1/2 lb., 20c; 1 lb., 40c: 2 lbs., $75 \mathrm{c}: 5$ lbs..

$\$ 1.75$, postpaid.

ROUND YEILOW SIX WEEKS-The pods are 4 to 5 inches long, oval-round, light green in color, almost stringless, fleshy and of good quality. Pkt., 10c; $1 / 2$ lb., 20c; 1 lb., 35c; 2 lbs., $65 \mathrm{c}$; 5 lbs., $\$ 1.50$, postpaid.

IMPROVED EXTRA EARIY RED VAIENTINE-Pods are round, long, slightly curved, excellent quality. The seed we supply is produced from stock seed that was selected for both earliness and quality. Pkt., 10c; $1 / 2$ lb., 20c; 1 lb., 35c; 2 lbs., $65 \mathrm{c} ; 5$ lbs., $\$ 1.50$, postpaid.

TENNESSPE GREEN POD-Prolific, foliage dark green; pods long, flat, irregular, bright green and excellent quality. Pkt, 10c; 1/2 lb., 20c; 1 lb., $35 \mathrm{c} ; 2$ lbs., $65 \mathrm{c} ; 5$ l..s., $\$ 1.50$, postpaid. 


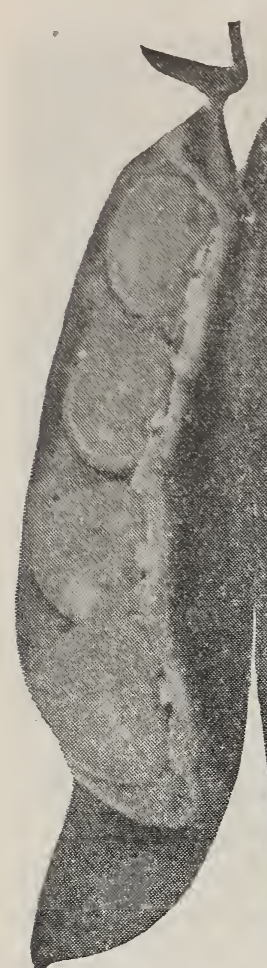

King of the Garden Lima Beans

\section{BUSH BEANS-WAX PODDED}

WARDWEIL'S KIDNEY WAX-A very popular, early gardeners' va. riety. Pods large, 5 to 6 inches long, moderately stout, straight and flat, fleshy, brittle, fine-grained and nearly stringless, and of good quality. Pkt. $10 \mathrm{c} ; 1 / 2$ lb., $20 \mathrm{c}$; 1 lb., 35c; 2 lbs., 60c; 5 lbs., $\$ 1.40$, postpaid.

IMPROVID GOIDEN WAX-Rust proof. Pods are about 4 inches long. very stout, and more straight than the old Golden Wax. Pkt., 10c; 1/2 lb., $20 \mathrm{c} ; 1$ lb., 35c; 2 lbs., $60 \mathrm{c}$; 5 lbs., $\$ 1.40$, postpaid.

CURRIP'S RUST PROOF WAX-Pods 5 to 6 inches ling, flat and straight, of bright yellow color. Pkt., 10c: 1/2 lb.. 20c: 1 lb., 35c; 2 lus. $60 \mathrm{c} ; 5$ lbs., $\$ 1.40$, postpaid.

DAVIS WHITE IIINEY WAX-6 to 7 inches long, large and flat, very uniform and straight, stringy and fibrous, of fair quality. Pkt., 10c; $1 / 2$ lb., 20c; 1 lb., 35c; 2 lbs., 60c; 5 lbs., $\$ 1.40$, postpaid.

\section{FIELD OR SHELLING VARIETIES}

WIITP NAVY-Vines are very prolific, producing a large quantity of shelled beans per acre. Cultivate same as Marrow Beans. Pkt., 10c; 1/2 lb., 20c; 1 lb., 35c; 2 lbs., 60c; 5 lbs., $\$ 1.40$, postpaid.

WEITT MARZOW-Plant in rows 3 feet apart, dropping 2 to 3 together, a foot apart in rows. Cultivate early, as they grow rapidly, but do not work them while the dew is on the foliage. Do not cultivate after they begin to bloom. Pkt., 10c; 1/2 lb., 20c; 1 lb., 35c; 2 lbs., 60c; 5 lbs., $\$ 1.40$ postpaid.

WIITE KIDNFY-Much used for shelling when pods turn yellow so the beans are well developed. Pkt., 10c; $1 / 2$ lb., $20 \mathrm{c} ; 1 \mathrm{lb} ., 35 \mathrm{c} ; 2 \mathrm{lbs} ., 60 \mathrm{c}$ 5 lbs., $\$ 1.40$, postpaid.

\section{LIMA BEANS \\ POLE VARIETIES}

One pound will plant about 150 hills.

Pole Limas require warm, rich, loamy soil. Plant when the soil has become well warmed through in the spring, as the seed will rot in cold, soggy soil. When poles are used for support they should be set not less than 4 feet apart each way. Plant 4 to 6 beans around each pole 2 inches deep and thin out to three plants to the pole. Cultivate frequently but shallow, and use a top dressing of good commercial fertilizer or poultry manure.

CAROIINA SIRVA OR SMAII IIMA-This is the true Butter Bean. The seed beans are very sinall and the plants are of large growth, very early, vigorous and pro-

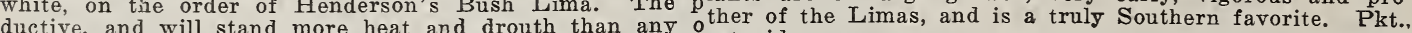
the $75 \mathrm{c} ; 5$ lbs $\$ 1.75$, ostpaid.

10 $1 / 2$ larger varieties for planting in the IARGE Wrized smooth, medium green leaves. The pods are borne in clusters and are over 5 inches long, broad, very thin. Pkt. $10 \mathrm{c} ; 1 / 2$ lb., 20c; 1 lb., $40 \mathrm{c} ; 2$ lbs., $75 \mathrm{c} ; 5$ lbs., $\$ 1.75$, postpaid.

KING OF THE GARDEN-An improved strain of the Large White Lima. The pods are about an inch longer, proportionately wider, and uniformly 4-seeded. The vines are hardy and bear abundantly. This is a standard sort and one of the best for main crop. The seeds are very large, ovoid, flat, white, with slight greenish tinge. Pkt., 10c; $1 / 2 \mathrm{lb}$. $20 \mathrm{c}$; 1 lb., $40 \mathrm{c} ; 2$ lbs., $75 \mathrm{c} ; 5$ lbs., $\$ 1.75$, postpaid.

SPECKIED OR CAIICO BUTTER BEANS-The most wonderful producer in the world. The beans are all colors, blotched, blue and red mottled; medium in size and superb in quality. This is an old garden variety. Pkt., $15 \mathrm{c} ; 1 / 2$ lb., $25 \mathrm{c} ; 1$ lb., $45 \mathrm{c} ; 2$ lbs., $85 \mathrm{c} ; 5$ lbs., $\$ 2.00$ postpaid.

\section{DWARF OR BUSH VARIETIES}

One pound will plant 100 feet of row, or 3 pecks to the acre.

Bush Limas require the same cultivation as stated above for Pole Limas, excent that the rows should be 2 feet apart and 6 inches of space between each plant in the row.

FINDERSON'S BUSH-One of the most valuable of the bush varieties owing to its extreme earliness and productiveness. The plants are with out runner but continue to grow and set until stopped by frost. The leaves are small and very dark green. Pkt., 10c; $1 / 2 \mathrm{lb} ., 20 \mathrm{c} ; 1 \mathrm{lb}$. $40 \mathrm{c}$; 2 lbs., $75 \mathrm{c}$; 5 lbs., $\$ 1.75$, postpaid

FORDIOOK BUSF-This is the only variety with a stiffy, erect bush form habit, branching freely but branches of upright growth. The pods are produced in large clusters, medium green, about 5 inches long and each containing 4 to 5 large beans of finest quality. Pkt., $10 \mathrm{c}$; $1 / 2$ lb., 25c; 1 lb., $45 \mathrm{c} ; 2$ lbs., $85 \mathrm{c}$; 5 lbs., $\$ 2.00$, postpaid.

BURPEE'S IMFROVED BUSF-This is one of the earliest of the large seeded Limas. The plants are vigorous and productive. The pods are niedium green, very large, about 5 inches long, containing 4 unusually thick and very large beans of excellent quality. Pkt., 10c; $1 / 2 \mathrm{lb} ., 25 \mathrm{c}$ 1 lb., 45c; 2 lbs., 80c; 5 lbs., $\$ 1.75$, postpaid.

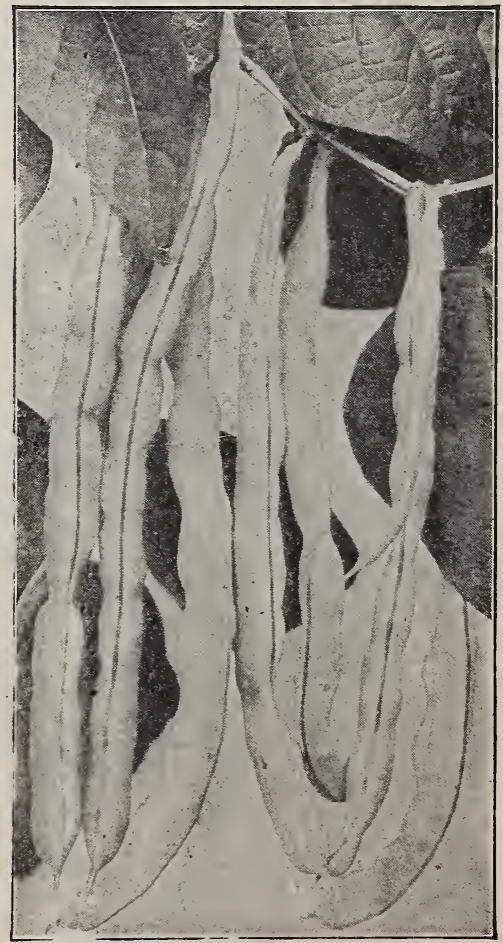

Improved Golden Wax Beans 


\section{POLE BEANS}

KFNTUCKY WONDER or OTD HOMESTEAD-Should be kept picked so that it will continue bearing until frost. The beans are 6 to 12 inches long, tender and rich. Pkt., $10 \mathrm{c} ; 1 / 2$ lb., $25 \mathrm{c} ; 1$ lb., $45 \mathrm{c} ; 2$ lbs., $80 \mathrm{c} ; 5$ lbs., $\$ 1.75$, postpaid.

WHITE CREASFBACK-This variety is valuable for quality and dark green color. Plkt.. 10c: 1/2 1b., 25c; $11 \mathrm{~b}$. , $45 \mathrm{c} ; 2$ lbs., $80 \mathrm{c} ; 5$ lbs., $\$ 1.75$, postpaid.

SCOTIA or STRIPID CREASEBACK-This is the real Cornfield Bean that you have read so much about. If you want a bean to plant in your corn, this is your one choice It will produce the kind of results that you'll expect. Pkt. 10c; 1/2 lb., 25c; 1 lb., 45c; 2 lbs., 80c; 5 lbs., $\$ 1.75$, postpaid.

RED SPECKIFD CUT SHORT-Pods nearly 4 inches long, stout, straight and flat, stringy, fine grained and ligh green color, of fair quality. Price: Pkt., 10c; $1 / 2$ 1b., 25c 1 lb., 45c; 2 lbs., 80c; 5 lbs., $\$ 1.75$, postpaid.

MCCASIAN POTF-When allowed to ripen shell beans are most excellent for winter use, being pure white. Pkt. $10 \mathrm{c} ; 1 / 2$ lb., 25c; 1 lb., 45c; 2 lbs., 80c; 5 lbs., $\$ 1.75$, postpaid.

IAZY WIFY POIY BEANS-A late variety of excellent quality. Fruits borne in clusters, pods averaging six inches in length; very fine flavor, round and stringless. Seer large, round and clear white. A fine variety to use dry. Price: Per plkt., 10c; 1/2 lb., 25c; 1 lb., 45c; 2 lbs., $80 \mathrm{c}$ 5 lbs., \$1.75, postpaid.

GOIDFN CIUSTFR WAX-An excellent early wax pod ded pole bean. The vines are large, vigorous and hardy with large, light green leaves. The pods are 6 to 8 inches long, extremely straight and flat; very fleshy, fine grained, good quality; color light waxy-yellow. Pkt., 15c; 1/2 lb., $30 \mathrm{c} ; 1$ lb. 50c; 2 lbs., 90c; 5 lbs., $\$ 2.00$, postpaid.

KEITUCKY WONDER WAX-This is one of the earliest of the wax podded sorts, and similar to the green poded Kentucky Wonder, but the pods are broader. The pods are very long, handsome light yellow, often over 8 inches long, very fleshy, brittle but stringy. Pkt., 15c;

$1 / 2$ lb., 30c; 1 lb., 50c; 2 lbs., 90c; 5 lbs., $\$ 2.00$, postpaid.

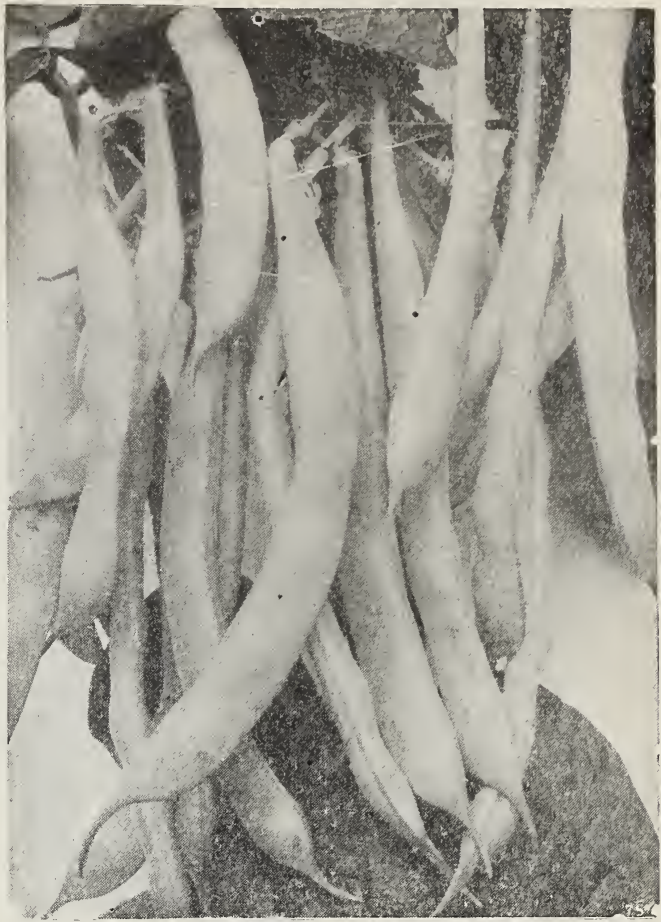

White Creaseback Pole Beans

\section{CHOICE TABLE BEETS}

One ounce will sow 50 feet of drill; 5 to 6 pounds to an acre.

Fibrous loam, well drained and well enriched, will raise good beet crops. For early table beets, have drills 16 to 20 inches apart, and sow the seed about 1 inches deep, as early as the ground can be put in good shape. Or, seed may be sown under glass four weeks sooner, and the young seedlings transplanted to open ground to give an extra early crop. Give thorough and clean cultivation, and thin the plants to 3 to 4 inches apart in the rows.

CROSBY'S EGYPTIAN-This is the earliest in the market. It does not closely resemble the original Egyptian except in its extreme earliness. Roots a flattened globe shape; skin very dark red, flesh a trifle lighter in

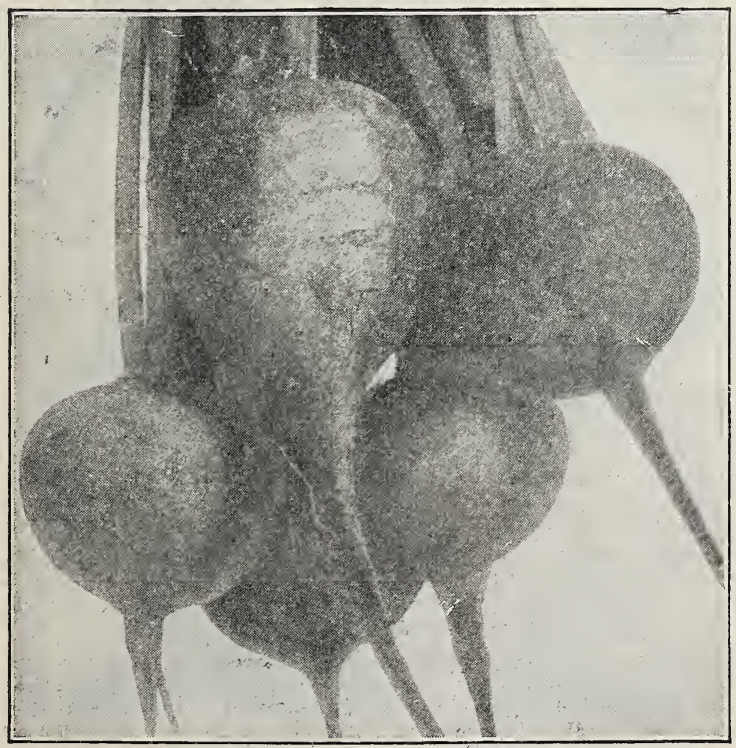

Detroit Dark Ked Beets color and lightly zoned; tops small. Pkt., 5c; 1 oz.,
$10 \mathrm{c} ; 2$ oz., $15 \mathrm{c} ; 1 / 4$ lb., 25c; $1,1 \mathrm{~b} ., 85 \mathrm{c} ; 5$ lbs., $\$ 3.50$, postpaid.

DETROIT DARK RED-One of the very best for home or market garden and for canning purposes. Roots uniformly smooth, of medium size, and globeshaped; skin dark red, flesh solid vermilion red. Tops are small, upright, dark green, shaded red; qual. ity the best. Pkt., 5c; 1 oz., 10c; 2 oz., $15 \mathrm{c} ; 1 / 4$ lb., $25 \mathrm{c} ; 1$ lb., $90 \mathrm{c} ; 5$ lbs., $\$ 4.00$, postpaid.

FARIY ECIIPSE-An early variety, especially desirable for the home garden, and used for bunching. The roots are medium size, round, bright deep red with small tops. The flesh is bright red, zoned with pinkish white, very sweet, crisp and tender. Pkt., 5c; 1 oz., 10c; 2 oz., 15c; $1 / 1$ lb., $25 \mathrm{c} ; 1$ lb., $80 \mathrm{c} ; 5$ lbs., $\$ 3.50$, postpaid.

BARIY BIOOD TURIIP, IMPROVED-An extra select stock of the old standard table beet; roots nearly round or slightly flattened, bright red, zoned, and of good qualiy. Not as early as Detroit, with a larger, coarser top. Pkt., 5c; 1 oz., 10c; 2 oz., $15 \mathrm{c}$; $1 / 4$ lb., $25 \mathrm{c} ; 1$ lb., 80c; 5 ibs., \$3.50, postpaid.

MARKFT WONDER-Tops are small and upright in growth; leaves dark green, shaded red; roots merium size, globular, very smooth and dark blood red: flesh deep vermilion red, zoned lighter. Pkt., 5c; 1 oz., 15c; 2 oz., 25c; $1 / 4$ lb., $40 \mathrm{c} ; 1$ lb., $\$ 1.25 ; 5$ lbs., $\$ 5.00$, postpaid.

IONG SMOOTI BIDOD-Late variety, roots are smooth, rather slender; flesh deep purplish red. Pkt., $5 \mathrm{c} ; 1$ oz., 10c; 2 oz., 15c; $1 / 4$ lb., 25c; 1 lb., 85c: 5 lbs., $\$ 3.50$, postpaid. 


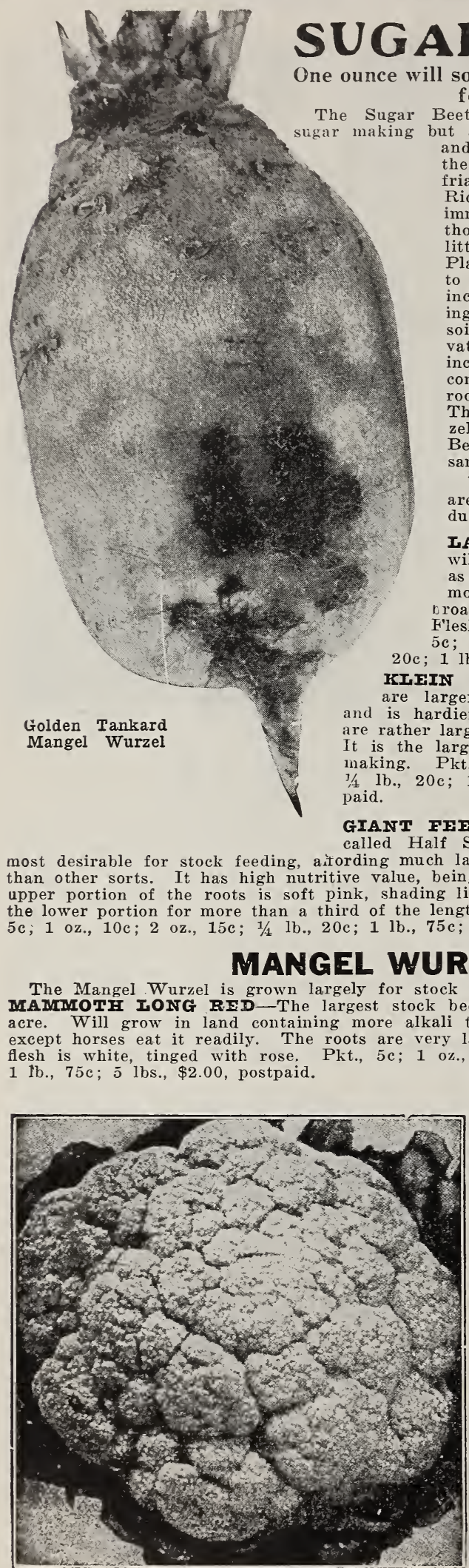

Early Snowball Cauliflower

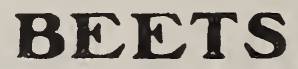

for an acre.

ets are desirable not only for ut are valuabie for stock feedins,
and when small may be used for the table. The best soil is a rich, friable sandy, or clayey loani. Rich, mucky soil will often give mmense yield of roots which though excellent for feed, are of Plant early in spring in drills 2 to $21 / 2$ feet apart, and about 1 inch apart in the row. cove . ing with about $1 \frac{1 / 2}{2}$ inches of fine soil firmly pressed down. Culti. ate frequently. When about 3 inches high begin thinning and continue at intervals until the roots stand about 10 inches apart. The sulture of the Mangel Wurzel, also called Mangel, Cattle Beet and Field Beet, is much the same as for Sugar Beets.

We list only those varieties that are known to be the best producers of beet sugar.

IANE'S IMPERIAI-This beet will yield almost as much in bulb as the best mangels and contains more sugar. The roots are smooth, road at the top and gradually taper. Flesh snow white and crisp. Pkt.,
$5 \mathrm{c} ; 1$ oz., $10 \mathrm{c} ; 2$ oz., $15 \mathrm{c} ; 1 / 1 \mathrm{lb}$., 1b., $75 \mathrm{c} ; 5$ lbs., $\$ 3.00$, postpaid. KIFIN WANZIFBEN-The roots and is larger than Vilmorin's Improved are rather large and the leaves slightly waved. It is the largest yielding and best for sugar making. Pkt., 5c; 1 oz., 10c; 2 oz., $15 \mathrm{c}$; paid. $20 \mathrm{c} ; 1$ lb., $75 \mathrm{c} ; 5$ lbs., $\$ 3.00$, post-

GIANT FFEDING SUGAR-Sometimes is

called Half Sugar Mangel, and one of the most desirable for stock feeding, aitording much larger crops and easier harvested upper portion of the mots is soft pink, shading lighter toward the bottom. where the lower portion for more than a third of the length is white. Flesh white. Pkt., $5 \mathrm{c} ; 1 \mathrm{oz} ., 10 \mathrm{c} ; 2$ oz., $15 \mathrm{c} ; \mathrm{1} / \mathrm{l} \mathrm{lb} ., 20 \mathrm{c} ; 1 \mathrm{lb} ., 75 \mathrm{c} ; 5 \mathrm{lbs}$., $\$ 3.00$, postpaid.

\section{MANGEL WURZEL}

MAMMOTH IONG RID-The largest stock beet, yields 40 to 50 tons to the acre. Will grow in land containing more alkali than any other beet. All stock except horses eat it readily. The roots are very large, uniformly straight and the flesh is white, tinged with rose Pkt., 5c; 1 oz., 10c; 2 ozs., 15s; $1 / 1$ lb., $20 \mathrm{c}$;

GOIDEN TANKARD-The tops are comparatively small, with the 1-leaf stalk and veins distinctly tinged with yellow. The neck is small. The roots are large, ovoid, but with bottom usually of larger diameter than top, light gray above the ground, deep orange below. The flesh is yellow, zoned with white. Pkt., 5c; 1 oz., 10c; 2 ozs., $15 \mathrm{c} ; 1 / 4$ lb., 20c; 1 lb., $75 \mathrm{c}$; 5 lbs., $\$ 3.00$, postpaid.

\section{CAULIFLOWER}

Cultivate like cabbage. Sow in January or February for early crop: May or June for late. Transnlant to rich. moist soil ; manure heavily and water freely. When heading begins, fasten leaves over top of head to whiten. One ounce of seed makes 2,000 palnts. We handle only the best quality seed.

EARIY SNOWBAII-Good forcing variety, and can also be used as a late crop for winter. Heads of medium size, solid, round, very white. Pkt., $25 \mathrm{c} ; 1 / 4$ oz., $75 \mathrm{c} ; 1 / 2$ oz., $\$ 1.25 ; 1$ oz., $\$ 2.00$, postpaid.

DANISH DRYWEATHER-This variety is especially valuable in sections subject to long, dry seasons, as it will do well and produce fine heads in lack of moisture. The heads grow to a large size, and are very solid but in quality perhaps not as tender as Early Snowball. Pkt., 25c; $1 / 4$ oz., $75 \mathrm{c}$; $1 / 2$ oz., $\$ 1.25 ; 1$ oz., $\$ 2.00$, postpaid. 


\section{CABBAGE}

One ounce will produce 3,000 plants.

For early use the seed should be started in the house or hotbed in January or February. When the young plants are well started, trans plant so as to stand 3 inches apart each way. About the end of March they may be transplanted into the garden in rows 3 feet apart, setting the plants 18 inches apart each way. For late use, sow the seed about the middle of May, or sowings can be made up to July 10 , in a finely prepared seed bed, later transplanting to rows 3 feet apart, setting the plants $2 \frac{1}{2}$ feet apart.

EARIY JERSEY WAKEFIELD A leading variety and one of the best for private or mar-
ket gardeners' use; conical shape. Pkt. $5 \mathrm{c}$; ket gardeners' use; conical shape. Pkt., 5c postpaid.

CHARIESTON IARGE WAKFFIELD This is a few days later, than the Early Jersey Wakefield, but makes a larger and firmer head. We strongly recommend it as the best main crop early cabbage grown, for the home garden and market. Our seed of this is grown from a specially selected stock. Pkt., 5c; $10 z, 25 c ; 2$ ozs, 40c; 1/ lb. $75 \mathrm{c}: 1$ lb., $\$ 2.75$, postpaid.

COPENHAGEN IMARIET-The earliest large round or flat-head sort. The ripening is early and uniform, maturing at one time and almost with Early Jerser Wakefield. Considering its early season, the heads are remarkably large, averaging ten pounds in weight. It has few outer leaves, which permits close planting, and it grows close to the ground on a short stem. Pkt., 5c; oz. $35 \mathrm{c} ; 2$ ozs., 60c; $1 / 4$ lb., $\$ 1.00 ; 1$ lb., $\$ 3.50$ postpaid.

EARIY FIAT DUTCF-Sure solid header; weighs 10 to 12 pounds each head, even size, mature about same time as

" Early Summer," a standard early: it stands long without bursting; as second early it is one of the best. Pkt., 5c; oz., 25c; 2 ozs., $40 \mathrm{c} ; 1 / 4$ lb., $65 \mathrm{c}$; 1 lb., $\$ 2.25$, postpaid.

SUCCESSION-This is one of the earliest of the very large heading sorts. The large, handsome, oval shaped heads make them profitable for both home and market gardens. Pkt., 5c; oz., 25c; 1/1 lb., 75c;1 lb. $\$ 2.50$, postpaid

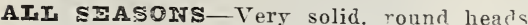
flattened on top. This cabbage has the abil. ity to withstand the hot sun and dry weath er and is good for autumn as well as sum mer use. Pkt., 5c: 1 oz., 30c; 2 ozs., $50 \mathrm{c}$. $1 / 1$ lb., $75 \mathrm{c} ; 1 \mathrm{~b} ., \$ 2.50$, postpaid.
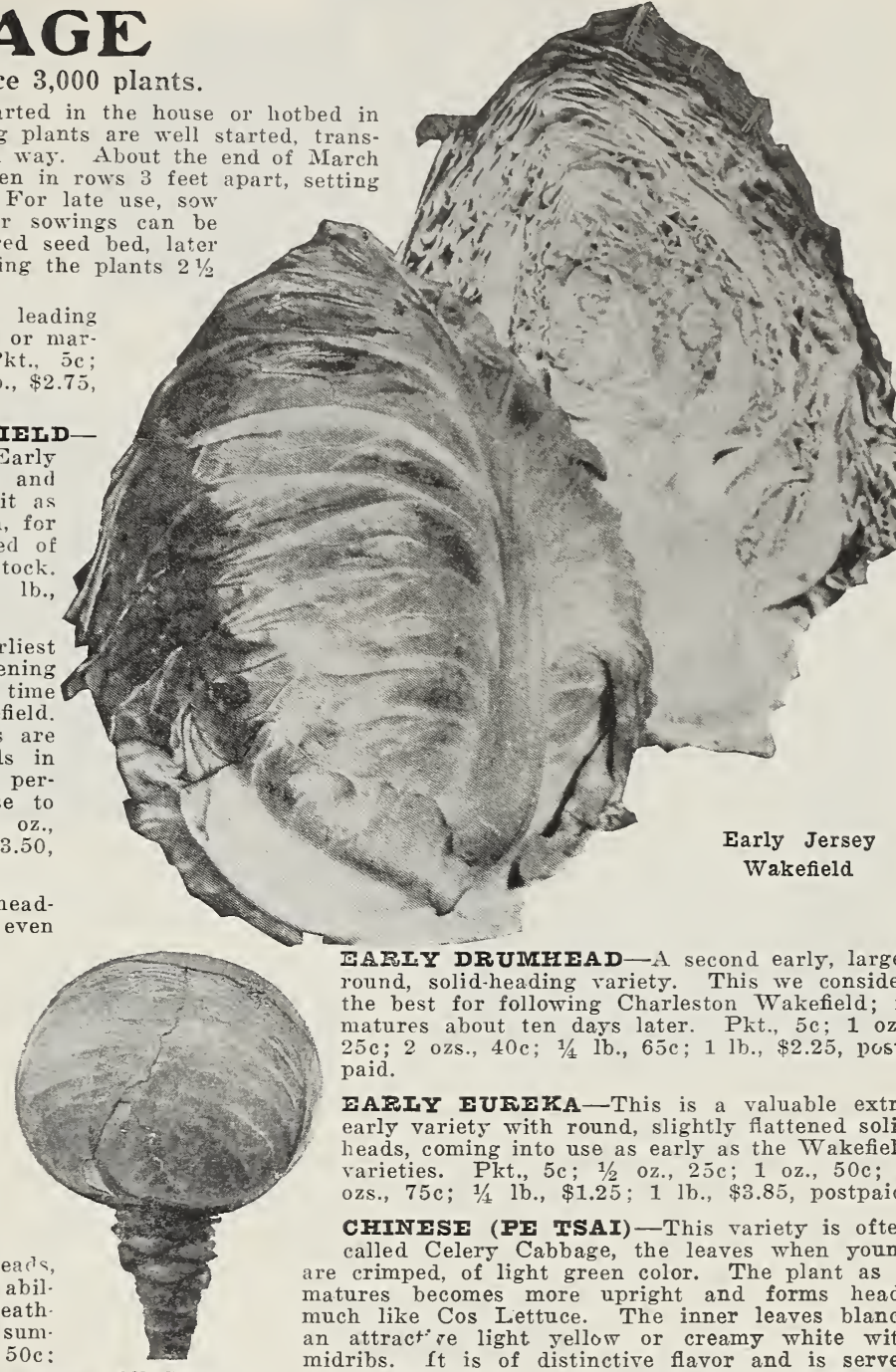

IARIY DRUMFEAD-A second early, large, round, solid-heading variety. This we consider the best for following Charleston Wakefield; it matures about ten days later. Pkt., 5c; 1 oz., $25 \mathrm{c} ; 2$ ozs., $40 \mathrm{c} ; 1 / 4$ lb., 65c; 1 lb., $\$ 2.25$, post paid.

EARIY EURERA-This is a valuable extra early variety with round, slightly flattened solid heads, coming into use as early as the Wakefield arieties. Pkt., 5c; $1 / 2$ oz., $25 \mathrm{c} ; 1$ oz., $50 \mathrm{c} ; 2$ ozs., $75 \mathrm{c} ; 1 / 1 \mathrm{l}$ lb., $\$ 1.25 ; 1$ lb., $\$ 3.85$, postpaid.

CFINISE (PE TSAI) - This variety is often called Celerr Cabbage, the leaves when young re crimped, of light green color. The plant as it matures becomes more upright and forms heads much like Cos Lettuce. The inner leaves blanch an attract: ve light yellow or creamy white with midribs. It is of distinctive flavor and is served as a salad like lettuce or cooked like asparagus. Pkt., 10c; oz., 35c: 2 ozs., 60c; $1 / 4$ 1b., $\$ 1.00 ; 1$ 1b., $\$ 3.50$, postpaid.

IARGE DRUMHEAD SAVOY-The best and largest heading of the Savoy Cabbage. Few people seem to know the delicious flavor of Savoy Cabbage. It is far superior to the flat-leaved sorts, and as tender as Cauliflower after frost. Pkt., 5c; oz., 35c; 2 ozs., $60 \mathrm{c} ; 1 / 4$ lb., $90 \mathrm{c} ; 1$ lb., $\$ 2.75$, postpaid.

IARGE IATE DRUMHEAD-Will stani the changeable conditions of weather of the South better than most sorts. Pkt., 5c; 0 z. $25 \mathrm{c} ; 2$ ozs., $40 \mathrm{c} ; 1 / 1 \mathrm{lb}$., $75 \mathrm{c} ; 1$ lb., $\$ 2.25$. postnaid.

MATMMOTH ROCK TED-Largest variet Red Cabbage; heads solid, round, spreading outer leaves; late. Pkt., 10c; 1 oz., 35c 2 ozs., 60c, postpaid.

AII FEAD EARIY-Deep fiat heads, solid and uniform of a very compact growth. Pkt., 5c: 1 oz., 25c; 2 ozs., $40 \mathrm{c} ; 1 / 1 \mathrm{lb}$. $75 \mathrm{c}: 1$ ib., $\$ 2.50$, postpaid.

TAGP TATE ETAT DUTCH-The best of the later varieties. Large heads of excollent quality which keeps well through the inter. It is the great favorite among marrardeners on account of its excellent ipping qualities. Pkt., 5c: 1 oz, 25c ; s.. 40c: $1 / 4$ lb. b5c: 1 lb. $\$ 2.25$, postpaid. 


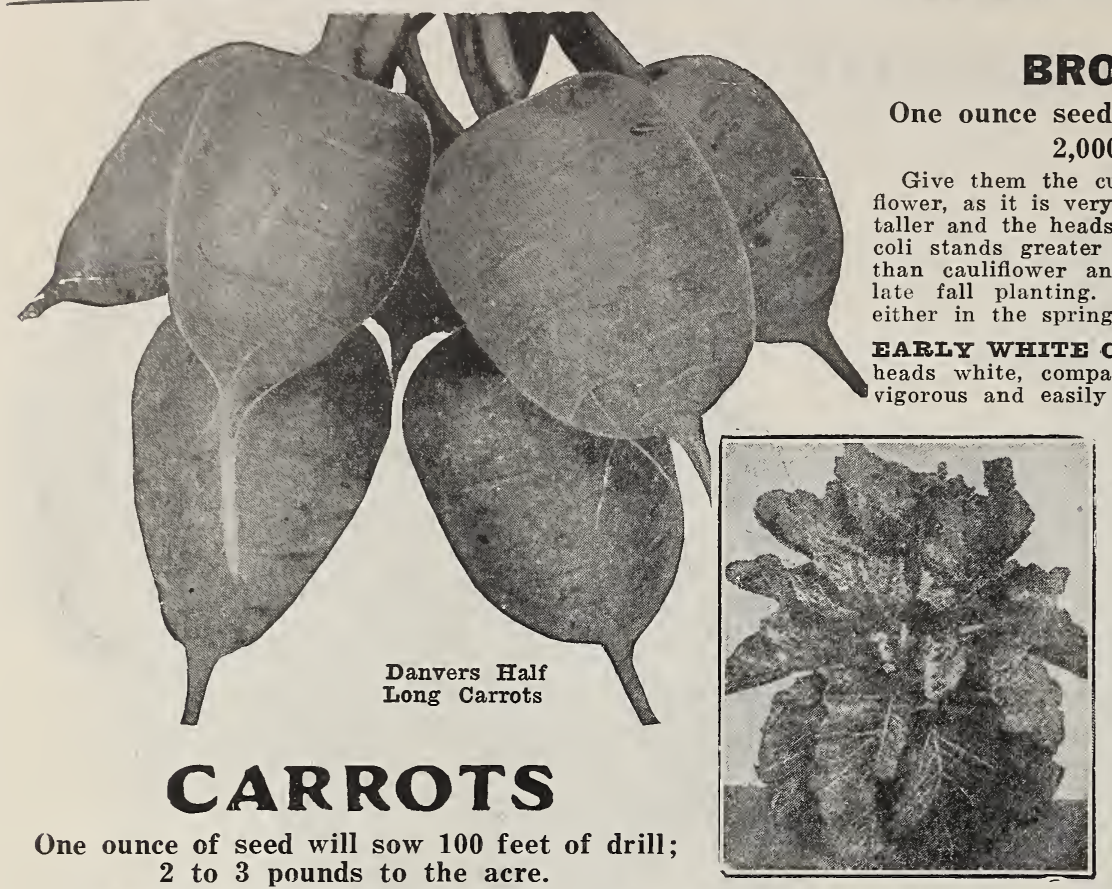

\title{
BROCCOLI
}

\author{
2,000 plants.
}

the culture required for cauli. it is very similar. It is generally taller and the heads are more divided. Broccoli stands greater extremes of temperature than cauliflower and is better adapted for croccoli can be sown pring or fall.

CAPF-The best variety; eads white, compact and hardy; a hardy. grown sort. Pkt., $10 \mathrm{c}$;
$1 / 2$ oz., $35 \mathrm{c} ; 1$ oz., $60 \mathrm{c}$, postpaid.

CORN SALAD OR FETTICUS

One ounce will sow about 18 sq. feet.

Reserve a place in the garden for some of this popular vegetable.

Sow in September or October. Large, round. leaved. Pkt., 5c; oz., $15 \mathrm{c} ; 2$ ozs., $25 \mathrm{c} ; 1 / 4$ lb., $35 \mathrm{c} ; \quad$ lb., $\$ 1.25$, parcel post paid.

The Carrot, like other root crops, delights in a sandy $y_{\text {Georgia }}$ White Cabbage Collard loam, deeply tilled. For early crops, sow in spring, as soon as the ground is in good working order; for late crops they may be
sown any time until the middle of July. Sow in rows about 15 inches apart, thinning out to 3 inches between plants.

DANVER FAIT IONG-Flesh dark orange, smonth, handsome ronts of medium length, tapering uniformly to a blunt point; very productive and a great favorite with market gardeners. Pkt., 5c; 1 oz., $15 \mathrm{c} ; 2$ ozs., $25 \mathrm{c} ; 1 / 4$ lb., 30c; 1 lb., $\$ 1.00 ; 5 \mathrm{lbs} ., \$ 4.50$, postpaid.

IMPROVED IONG ORANGE-An old standard and very popular variety, growing to large size; fine for market; one of the best varieties for stock feeding. Pkt., 5c; 1 oz., $10 \mathrm{c} ; 2$ ozs., 15c; $1 / 4$ lb., 30c; 1 lb., $\$ 1.00$; 5 lbs., \$4.50, postpaid.

EARIY SCARIFT HORN-Not large, but a favorite for early crop. Small tops, stump rooted, orange flesh and fine grain. Pkt., 5c; 1 oz., $10 \mathrm{c} ; 2$ ozs., $15 \mathrm{c}$; $1 / 4$ lb., $30 \mathrm{c} ; 1$ lb., $\$ 1.00 ; 5$ lbs., $\$ 4.50$, postpaid.

OX HrarT-Stump rooted, 3 to 4 inches in diameter, flesh bright orange, fine grained and sweet; very productive. Where other varieties require digging, $\mathrm{Ox}$ Heart is easily pulled. Pkt., 5c; 1 oz., 10c; 2 ozs., 15c; $1 / 4$ lb., 30c; 1 lb., $\$ 1.00 ; 5$ lbs., $\$ 4.50$, postpaid.

\section{COLLARDS}

One ounce will produce about 1,500 plants, or 150 feet of row.

It produces a plant bearing a mass of leaves on the top of a stout stalk, and is a species of cabbage, and the flavor is the same. It is extensively used for the table, for winter greens, throughout the South. Sow the seed thickly in drills, in rich ground, transplanting when about four inches high. In the South, seed may be sown from January to May and from August to October.

GFORGIA WHITE CABBAGE-Whiter and more tender than the Blue Stem. Introduced 15 years ago. Three-fourths of them bunch or head up in winter, weighing 10 pounds or more. Plants grow 30 to 40 inches high and as niuch across. Pkt., 5c; 1 oz., 10c; 2 ozs., 20c; $1 / 4$ lb., 35c; $1 \mathrm{lb}$., $\$ 1.00$, postpaid.

SOUTHERI or GFORGIA-This variety is the old-time favorite. It stands all sorts of adverse conditions without injury and will make a good crop where the soil is too poor to grow cabbage, and it makes an excellent substitute for that vegetable. Is very hardy. Pkt., $5 \mathrm{c} ; 1$ oz., $10 \mathrm{c} ; 2$ ozs., $15 \mathrm{c} ; 1 / 1$ lb., $35 \mathrm{c} ; 1$ lb., $\$ 1.00$, postpaid NORTH CAROIINA-A decided improvement, and has proved very popular wherever grown. Has short stem, large spreading leaves, very hardy, withstanding drouth in summer and cold in winter. Its cooking qualities are the best. Pkt., $5 \mathrm{c} ; 1$ oz., $10 \mathrm{c} ; 2$ ozs., $15 \mathrm{c} ; 1 / 4$ lb., $35 \mathrm{c} ; 1$ lb., $\$ 1.00$, postpaid.

\section{CHICORY}

One ounce will sow 100 feet of row.

Chicory is grown for the large, thick roots, which are dried, roasted and ground, as a substitute or adulterant for coffee. The leaves are also used as a salad during the early spring months. To secure large, smooth roots, the soil should be light, rich, and deeply worked, and the plants should be thinned out to stand 4 to 6 inches apart.

IARGE-ROOTED or COFFE卫-Pkt., 10c; 1 oz., 30c, postpaid.

WITIOOF-CHICORY or FRENCF FNDIVE-Pkt., 10c; 1 oz., $50 \mathrm{c} ; 2$ ozs., 90c, 


\section{CELERY}

One ounce of seed will produce 3,000 plants

Celery does well in muck land but can be grown in any good-preferably moist-garden soil. Sow in rich soil, in boxes inside or in frames under glass. When plants are 2 inches high, transplant again in boxes or cold frames 2 inches each way. Seeds germinate slowly in about 20 days. Dig trenches 4 feet apart and 6 inches deep, set the plants 6 to 8 inches apart in the trench.

WHITE PIUME-An attractive quick growing early variety, well known for the short time necessary in blanching. Suitable for the home garden and market on account of earliness. Iniported stock. Pkt., 5c $1 \mathrm{oz} ., 25 \mathrm{c} ; 1 / 4 \mathrm{lb}$., $75 \mathrm{c}$, postpaid.

GOIDFN SEIF-BIANCFING-This grand Celery is of French origin. It has the same self-blanching habits as White Plume, but is heavier and more compact, though not so early. Grows to good size, is very tender and free from strings, the heart large and solid, crisp, brittle. of excellent quality, and beauiful golden color. Pkt., 5c; 1 oz... 50c; $1 / 1 / 4$ lb., $\$ 1.25$, postpaid.

GIANT PASCAI-The stalks are large, thick, solid and crisp. Fine keeper. Has an agreeable almond flavor and is absolutely free from bitterness. It requires but little earthing up to blanch and keeps its freshness a long time after being marketed. Pkt., 5c; 1 oz., 25c; 1/ lb., $75 \mathrm{c}$, postpaid.

\section{CELERIAC OR ROOTED CELERY}

One ounce for 5,000 plants

LARGI SMOOTH PRAGUE-A turnip-rooted celery which keeps well for winter use. Used largely for flavoring soups. The variety offered here is perhaps the best and most widely known. Produces a smooth and almost round root. Pkt., $5 \mathrm{c} ; 1$ oz., $25 \mathrm{c} ; 1 / 4 \mathrm{lb} ., 75 \mathrm{c}$, postpaid.

\section{CUCUMBERS}

One ounce will plant 50 hills; 2 pounds will plant one acre.

For very early cucumbers plant in paper pots or dirt bands, in hot beds, about the second week in March. Transplant as soon as the weather permits. In the open, plant about the first of April, as soon as the weather becomes settled, in hills 4 feet each way; thin to 3 of the sturdiest plants when they begin to vine. The soil should be a rich, sandy loam. Continue to plant for succession until the middle of July, Cucumbers should be gathered when large enough for use, whether required or not, as ripening destroys their productiveness.

IMPROVED IONG GREEN-A standard variety used for slicing while young. With age it turns to a rich golden yellow, when it can be used for sweet pickles. This cucumber should be in every garden where a general purpose variety is most desired, as the various stages of development of the fruit can be utilized for a large assortment of delicious dishes. Pkt., 5c; 1 oz., $15 \mathrm{c} ; 2$ oz., $25 \mathrm{c}$; $1 / 4$ lb., $40 \mathrm{c} ; 1$ lb., $\$ 1.25 ; 5$ lbs., $\$ 5.25$, postpaid.

IMPROVED FARIY WHITE SPINE-One of the very earliest and best known of the White Spines; a short, square-ended, rather three-cornered type; very productive. Pkt., 5c; 1 oz., $15 \mathrm{c} ; 2$ ozs., $25 \mathrm{c} ; 1 / 4$ lbs., $\$ 5.25$, postpaid. K,TONDYKE-8 inthes long, uniform shape, dark green, slightly striped at ends. The fruit is a good shipper. Pkt., $5 \mathrm{c} ; 1$ oż. $15 \mathrm{c} ; 2$ ozs., $25 \mathrm{c} ; 1 / 4$ lb., $40 \mathrm{c} ; 1$ lb., $\$ 1.25 ; 5$ ibs., $\$ 5.25$. postpaid.

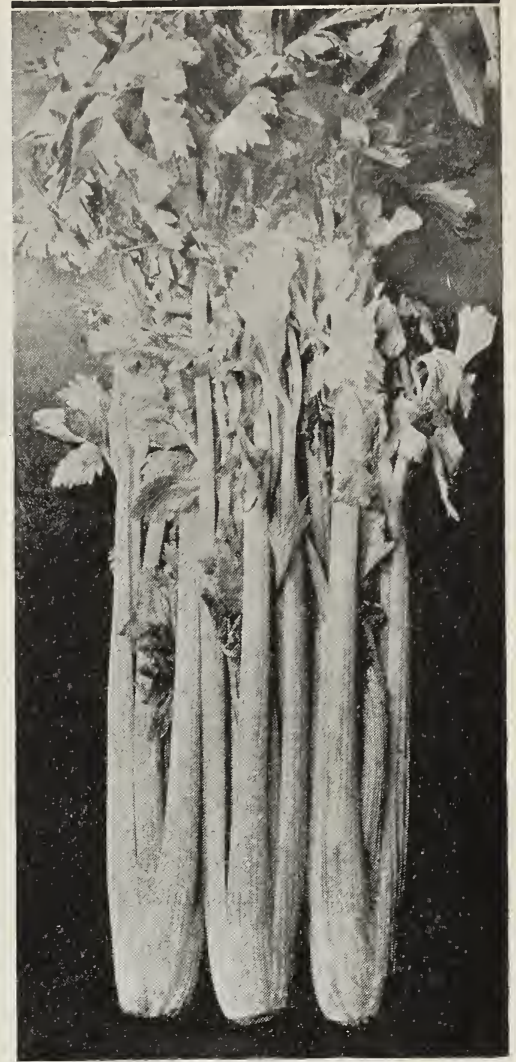

Golden Self Blanching Celery

EARIY CLUSTRR-Vines hardy and vigorous, beariug fruits in clusters of two or three. Fruits soft, thick, bright green, shading lighter at blossom end, crisp and tender. Pkt., 5c; 1 oz., 15c; 2 ozs., $25 \mathrm{c}$; $1 / 4 \mathrm{lb}$., $40 \mathrm{c}$; 1 lb., $\$ 1.25$; 5 lbs., $\$ 5.25$, postpaid.

GHERKIN or BURR-Grown for pickles. Fruit small, covered with pines. Pkt., 10c; 1 oz., $25 \mathrm{c} ; 2$ ozs., $40 \mathrm{c}$; $1 / 4$ lb., 60c; 1 lb., $\$ 2.00$, postpaid.

JAPANESE CIMMBING-Climbing sort; fruits 10 in. long, thick, crisp and dark green. Pkt., 5c; 1 oz., 20c ; 2 ozs., 35c; $1 / 4$ lb., 60c; 1 lb., $\$ 2.00$.

CUMBRRIAND PICKIE - Hardy and rapid grower. Flesh firm, crisp and tender. Pkt., 5c; 1 oz., 15c; 2 oz., 25c; $1 / 4$ lb., $40 \mathrm{c}$; 1 lb., $\$ 1.50$, postpaid. DAVIS PERFECT Long, dark green; flesh crisp, solid, with few seeds. Pkt., 5c; 1 oz., $15 \mathrm{c} ; 2$ oz., $25 \mathrm{c} ; 1 / 4$ lb., $40 \mathrm{c} ; 1$ lb., $\$ 1.25 ; 5$ $40 \mathrm{c} ; 1$ lb., $\$ 1.25 ;$
libs., $\$ 5.25$, postpaid.

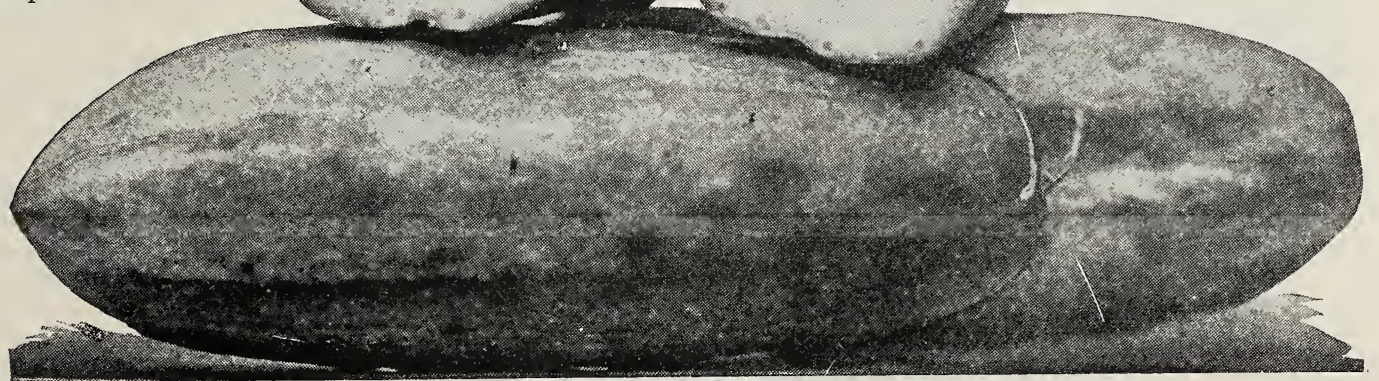




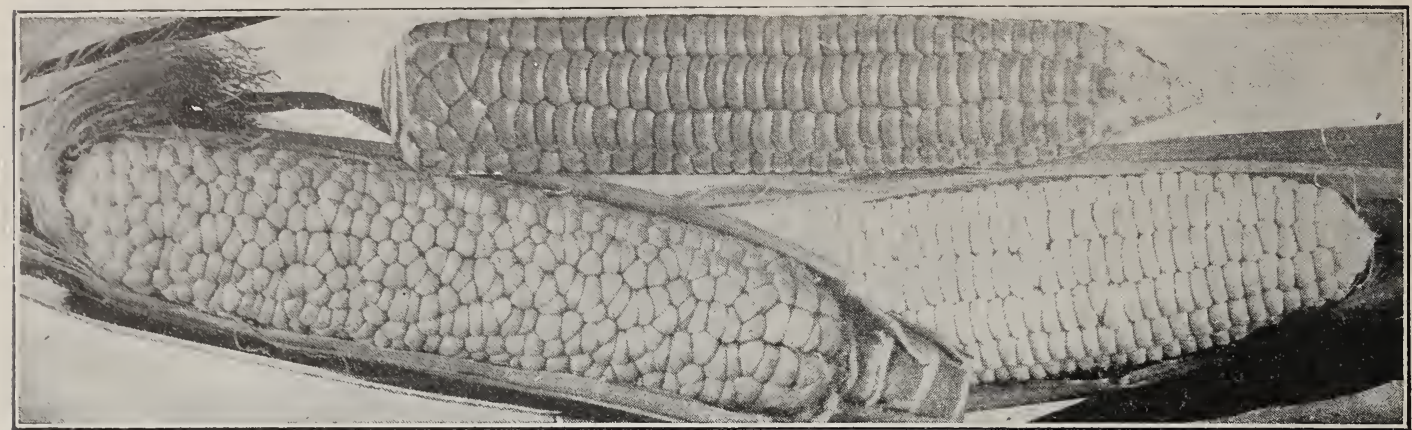

\section{SWEET AND}

One pound will plant 200 hills; 14 pounds will plant one acre.

Sweet Corn varies greatly in hardiness, earliness, size and sweetness. The early sorts grow only 3 to 5 feet high and may be planted when the trees are starting ou in leaf, about the middle of March, in rows 3 feet apart, making the hills about 1 foot apart. The later and sweeter varieties are more tender and should not be planted until the trees are in full leaf or the seed will rot in the ground. Plant garden corn in rows 3 feet apart, making the hills 18 inches apart in the rows.

EXTRA FAREY ADAMS-Hardiest and earliest variety, but not a sweet corn. Brings a good price when first offered on the market. Pkt., 10c; 1 lb., 25c; 2 lbs. $45 \mathrm{c} ; 5$ lbs., $\$ 1.00$, postpaid.

ADAIMS IARGr FARIY-Similar to Adams Early, but two weeks later, and has much larger ears. This and the Adams Extra Early are very hardy and can be plantl stalks and can be pianted close. Pkt. $10 \mathrm{c} ; 1 \mathrm{lb} .25 \mathrm{c} ; 2$ lbs., $45 \mathrm{c} ; 5 \mathrm{lbs}$., $\$ 1.00$ postpaid.

GOEDEN BANTAII-Finest home garden variety, and in a class by itself for quality. Superior in many ways to other Sweet Corn. Very early, sweet and tender. Cobs are well filled with deep cream colored kernels. We cannot recommend this variety too highly for the home garden. It is important that the corn be picked about 3 to 4 days after it has taken on yellow hue. If picked later than this it is apt to be over ripe and cook hard. Pkt: 10c; 1 lb., 35c; 2 lbs., 60c; 5 lbs., $\$ 1.25$ postpaid.

COUNTRY GFNTIIMLIN-A fine mid season variety, sometimes called "Shoe Peg," owing to the shape of the kernels Very sweet and tender. Very prolific and remains ready for use longer than any other kind. Pkt., 10c; 1 lb., 35c; 2 lbs.. 55c 5 lbs., \$1.10, postpaid.

STOWEIL'S EVRRGRIRN -A most popular main crop variety, and splendid for table use, the quality being excellent. The stalks are of strong growth. about 6 feet high; the 12-rowed ears are ahout 8 in. long and keep in table condition a remarkably long time. Our stock has been carefully grown and selected. This is one of the best known of the late sorts. Pkt., 10c; 1 lb., $30 \mathrm{c} ; 2$ lbs., 55c; 5 lbs., $\$ 1.25$, postpaid.

MAMMOTH or I A R G F SUGAR - This tall-growing sugar corn produces the larg-

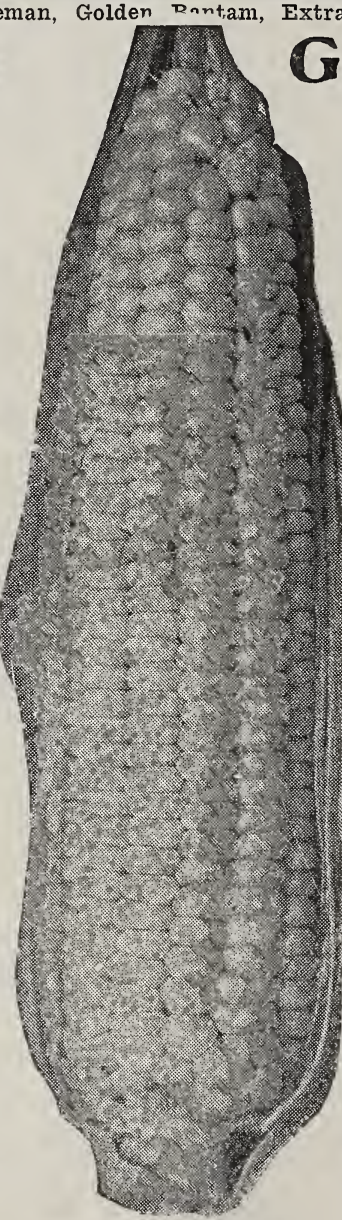

Stowell's Evergreen

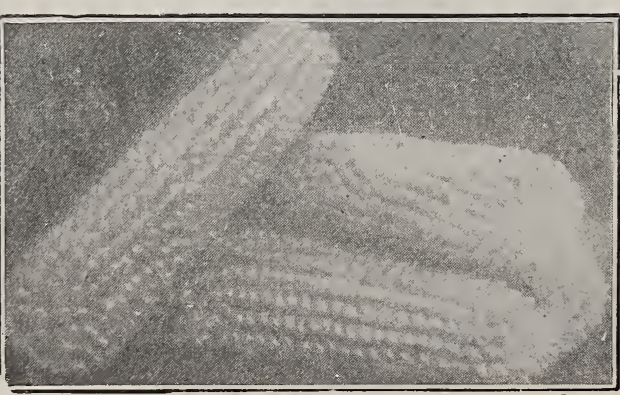

White Rice Popcorn est ears of any sweet corn. The ears are often 12 inches long and are noted for their sweetness and delicious quality. The grain is pure white, and the ears remain long in the green state. The ears are 16 to 18-rowed; an excellent sort for canning and for the late garden. Pkt., 10c; $1 \mathrm{lb}$. $35 \mathrm{c} ; 2$ lbs., $55 \mathrm{c} ; 5$ lbs., $\$ 1.25$, postpaid. COTDFN GIANT SWFFT CORN-As good as Golden Bantam to eat and very much larger-That sentence will describe Golden Giant to you in the best way. You know how tenderly delicious and sweet Golden Bantam is. Pkt., 10c; 1 lb., 40c 2 lbs., $75 \mathrm{c} ; 5$ lbs., $\$ 1.50$, postpaid.

FARIY SURPRISE-A fine garden corn coming in very little later than Adams and with a much larger ear. Pkt., 10c: 1 lb., 25 c; 2 lbs., $45 c$; 5 lbs., $\$ 1.00$. postpaid.

Larger quantity prices, see page 49 .

\section{POP CORN FOR SEED}

Plant 12 lbs. to acre in drills, 5 to 8 lbs. to acre in hills.

Pop Corn is a very profitable crop, vields well even in unfavorable weather and there is always a good market for it. Cultivate the same as field corn.

QUIEN'S GOIDIN-The largest pop corn. The stalk grows 5 to 6 feet high and bears 2 to 3 large ears each. It is yellow, but pops perfectly white.

WEITE RICB-A vert handsome and prolific white variety. The ears are 5 to 7 inches long. The kernels are long, pointed and somewhat resembling rice. This excellent, rather late maturing variety yields heavily and is considered the best pop corn for popping.

WHITE PEARI-This is a small grain variety, being a smaller kernel than the Queen's Golảen or White Rice. It also has a small cob, but is a very prolific variety and seems to do best in the southwest. PRICES, above three kinds: Pkt., $10 \mathrm{c} ; 1$ lb., $30 \mathrm{c} ; 2$ lbs., 55 c; 5 lbs., $\$ 1.10$, postpaid.

\section{CRESS OR PEPPER PLANT}

One ounce will sow about 15 square feet.

A well-known pungent salad. Sow at frequent intervals to keep up a succession, as it soon runs to seed. CURIED or PEP P E GRASS-Pkt., $5 \mathrm{c}$; oz., $20 \mathrm{c}$; 2 oz., 30c; 1/t lb., 50c; 1 lb., $\$ 1.25$, postpaid. 
Early White Vienna Kohl Rabi

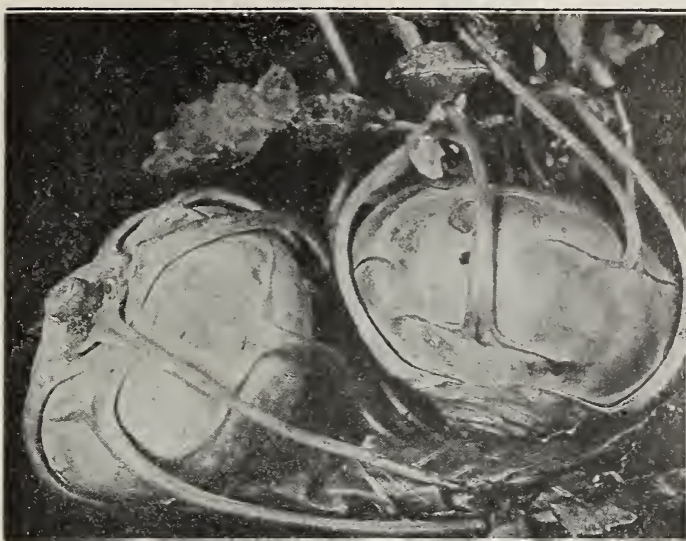

\section{EGG PLANT}

One ounce will produce one to two thousand plants.

Start the seed in hotbed early in March and when all danger from frost is over and the nights are warm transplant to open ground, allowing 3 feet space between the rows and 1 feet space between the plants in the row. The soil for Egg Plants cannot be too rich. Egg Plant seed requires a higher temperature for gernination tlian any other garden vegetable and this temperature should be maintained right along in the hotbed in order to secure strong and healthy plants.

BIACK BEAUTY-Is 12 days earlier than New York; for northern home gardens and truckers it is most de. sirable. In shape it is broad and thick; it is perfectly spineless and smooth; has beautiful, rich purple color and handsome lustre-very attractive and popular. Pkt., $5 \mathrm{c} ; 1 / 2$ oz., $25 \mathrm{c} ; 1$ oz., $40 \mathrm{c} ; 1 / 1$ lb., $\$ 1.25 ; 1$ lb., $\$ 4.50$, postpaid.

NEW YORI PURPLE-An entirely spineless strain of the large purple-fruited, well-known standard, and is a favorite. Our stock is extra selected from best

\section{ENDIVE}

One ounce will sow 300 feet.

Endive is grown in the same way as lettuce, but requires a longer time to develop. It takes about 50 days to grow a crop. Endive should be blanched by tying up the outer leaves like celery when the plants are full grown. Draw up the soil about the plants. GREFN CURIED-Resembling a tuft of moss, and one of the best salads. Foliage finely cut; crisp, tender and fine flavor. Valuable salad plant for fall and winter use. Pkt., 5c; oz., $20 \mathrm{c} ; 2$
ozs., $35 \mathrm{c} ; 1 / 1$ lb., 50c; 1 ib., $\$ 1.50$, postpaid.

BROAD IFAF BATAVIANThis variety has rather smooth leaves, with thick, nearly white mid ribs. Inner leaves form a fair head which blanches cream white. Pkt., 5c; oz., $20 \mathrm{c} ; 2$ ozs., $35 \mathrm{c}$;- $1 / 1 / 1$ lb., $50 \mathrm{c}$; 1 lb., $\$ 1.50$, postpaid.

\section{KOHL RABI}

One ource will sow 200 feet of row.

seed should be sown in light, rich soil, as early in spring as possible, in rows $1 \frac{1 / 2}{2}$ feet apart and when well established thin to 6 inches apart in the row. Plantings at intervals of ten days will give a succession until hot weather, when they fail to growy well. Plantings may be made the latter part of August for fall use. The edible part of Kohl Rabi is the turnip-shaped bulb formed above the ground.

EARIY WHITE VIENNA-This variety is extremely early with distinctly small top. The bulbs are of medium size, very light green or nearly white, and are of best quality for the table if used when about 2 inches in diameter. Pkt., 10c; 1 oz., 30c; 2 ozs, $50 \mathrm{c} ; 1 / 1 \mathrm{lb}, 75 \mathrm{c} ; 1 \mathrm{lb}$, $\$ 2.75$, postpaid.

\section{DANDELION}

One ounce will sow 100 feet of row.

For good, tender greens plant in deep, rich soil. Sow in rows 18 inches apart and thin to 6 to 8 inches in the row. Cultivate and keep clean and plants will be large enough for use the following spring. This crop is handled and used in the same way as Spinach. When roots are desired sow in fall, cultivate well for use the following fall. Roots are used for medicinal purposes.

IMPROVED THCK-IFAVID - Pkt. $10 \mathrm{c} ; 1 / 2$ oz., $35 \mathrm{c} ; 1$ oz., $60 \mathrm{c}$. postpaid. growers in New Jersey. Pkt., $5 \mathrm{c}$; $1 / 2$ oz., $25 \mathrm{c} ; 1$ oz., $40 \mathrm{c}$; $1 / 1 \mathrm{lb}$. EARIY IONG PURPIE-One of the earliest and most productive sorts; fruits club shaped, 6 to 8 inches long; rich purple, fine quality. Pkt., 5c; $1 / 2$ oz., $25 \mathrm{c} ; 1$ oz., $40 \mathrm{c} ; \quad 1 / 4$ lb., $\$ 1.25 ; 1 \mathrm{lb}$. $\$ 4.50$, postpaid.

\section{CHERYIL}

Used for flavoring or garnishing. Sow in early spring in rich soil, and when plants are large ellough, transplant to a foot apart. Price, pkt., $10 \mathrm{c} ;$ oz., $25 \mathrm{c}$; 2 oz., $50 \mathrm{c}$, postpaid.
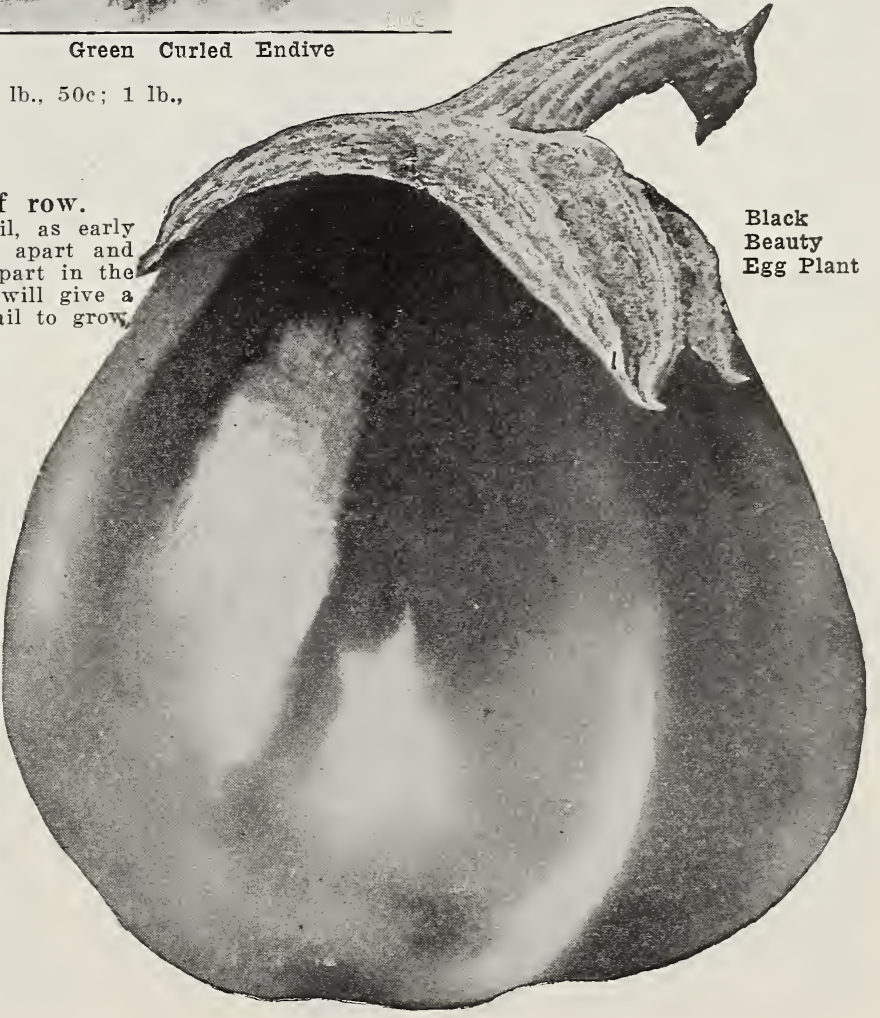


\section{LETTUCE}

One ounce will produce 3,000 plants.

For early use sow under glass in January or early February, and transplant as early as the ground can be put in good shape. Sowings may be made in open sround from April until July and again at the end of August for fall supply. Lettuce should be transplanted in rich, moist ground in rows 2 feet apart and plant 1 foot apart in the row.

SEIECTID BIG EOSTON-Our strain of this very popular variety is unsurpassed. Plants are large and vigorous. Can be sown in the open ground in the spring or fall, or in frames for early spring planting, does particularly well in cold weather, and is especially recommended for fall planting in the South. I rery popular with gardeners and truckers. Pkt., $5 \mathrm{c}$; 1 oz. $25 \mathrm{c} ; 2$ ozs., $40 \mathrm{c}$; $1 / \mathrm{lb} .60 \mathrm{c} ; 1 \mathrm{lb} ., \$ 2.00 ; 5$ lbs $\$ 8.75$, postpaid.

NEW YORI or WONDERFUI-This is the largest of all head lettuce, forming crisp heads often weigh. ing two pounds. It matures slowly, first forming a conical head which becomes globular with maturity. It is of excellent quality, very sweet, and stands the hot weather well. Because of its size it must be given plenty of room between plants. This variety is known in some sections as Los Angeles. Pkt., 5c; oz., 30c; 2 ozs., $50 \mathrm{c} ; 1 / 1 \mathrm{lb} ., 90 \mathrm{c} ; 1 \mathrm{lb} ., \$ 3.00$, postpaid.

ICFBERG-This is of the distinct crisp-head or cabbage-head trpe. It differs from all described above in having mid-ribs which bend in, curving over the center, forming most tightly folded heads. One of the most delicious of the entire crisp-head class, becoming ready for use in from 80 to 85 days after sowing seeds. Pkt., $5 \mathrm{c}$; oz., 25c; 2 ozs., $40 \mathrm{c} ; 1 / \mathrm{lb}$ lb, $75 \mathrm{c} ; 1$ lb., $\$ 2.50$. postpaid PRIZIARAD - Very popular, large, loose heading sort. Leaves finely crum. pled and fringed, outer ones shaded brown. very crisp, sweet and tender, splendid for home garden. Pkt., 5c; oz., 20c; 2 ozs., $30 \mathrm{c}$; $1 / 4 \mathrm{lb}$., $50 \mathrm{c}$; $1 \mathrm{lb}$., $\$ 1.50$, postpaid.

EANSON-The head is crisp and brittle and flavor excellent. Pkt., $5 \mathrm{c}$; oz., $20 \mathrm{c} ; 2$ ozs., $35 \mathrm{c} ; 1 / 1 \mathrm{lb} ., 50 \mathrm{c} ; 1$ lb., $\$ 1.50$, postpaid.

FUBBARD'S MARTET-An excellent heading variety for forcing or open ground; heads globular, very firm and well blanched; leaves broad, fairly blistered and crumpled, thick and stiff; color medium green; quality the best. Pkt., $5 \mathrm{c}$; 1 or.

HARDY WHITE COS-This is distinct from the ordinary lettuce, and is much liked on account of its crisp,

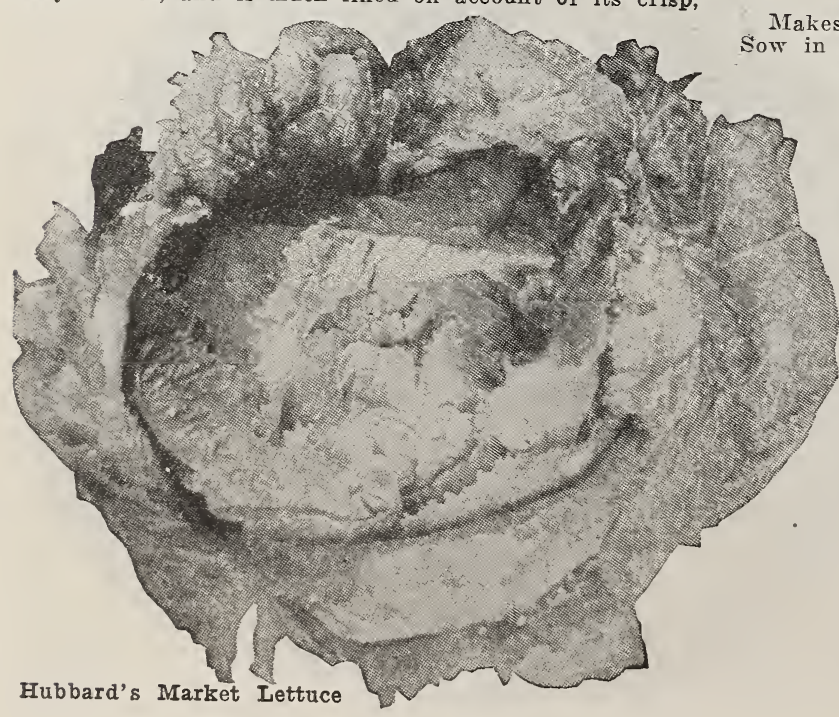

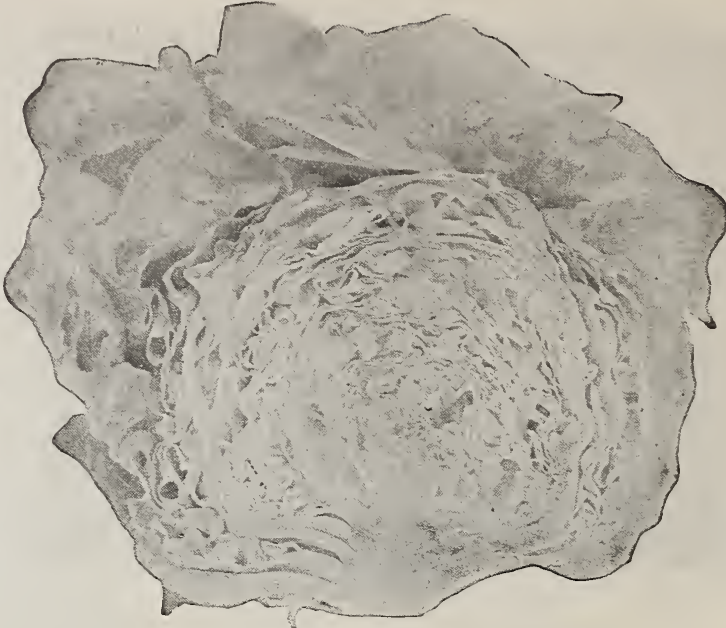

Iceberg Lettuce

tender quality and delicate flavor; grows to very large size, producing long, pointed, compact bunches. Pkt., sc; 1 0z., $20 \mathrm{c} ; 2$ ozs., $35 \mathrm{c}$; 1/1 lb., 60c, postpaid.

FARIY CURIED SIMPSON-This is theold favorite popular loose head variety of dwarf, compact habit and quick growth. The curly leaves are large, zellowish green with finely curled edges. Very crisp and tender. Matures early. quite hardy and withstands heat and drouth. Pkt., 5c; 1 oz., 20c; 2 oz., $35 \mathrm{c}$. 1/4 lb.. 50c: 1 lb.. \$1.50, postpaid.

AII SEASONS-Heads are large, solid and handsome, almost as large as Flat Dutch Cabbage; leaves are gray. This sort is a sure header and slow to run to seed. Pkt., $5 \mathrm{c}$; oz., $20 \mathrm{c} ; 2$ ozs. $35 \mathrm{c}$; $1 / 1$ lb., $65 \mathrm{c} ; 1$ lb., $\$ 2.00$, postpaid.

MIGNONGTTE - Is small and has tightly set leaves which makes a small extremely solid head. Pkt., $5 \mathrm{c}$; oz., $30 \mathrm{c}$ 2 ozs., 50c; $1 / 1 / 1$ lb., $90 \mathrm{c}$, postpaid. CAIIFORIIA CREAII BUTTERFor autumn and winter use. Large head which is very buttery and of a rich golden-yellow inside. Pkt.. $5 c$ : 1 rich 2 oz. $35 \mathrm{c} ; 1 / 1 \mathrm{lb}$., $65 \mathrm{c} ; 1 \mathrm{lb}$. \$1.85. ppd

\section{KALE}

Sow from 2 to 3 pounds to the acre. one ounce to 200 feet of drill.

Makes excellent greens for spring and win. DWARF GREEN CUIED-This is the most popular variety grown, especially in the South. Pkt., 5c; 1 oz., 10c; 2 ozs., 15c; $1 / 1$ lb., 25c; 1 lb., $75 \mathrm{c}$; 5 lbs., $\$ 3.25$, postpaid.

TAII CURIFD SCOTCH-A beautiful curled tall growing variety. Also fine for spring planting. Pkt., $5 \mathrm{c} ;$ oz., $15 \mathrm{c} ; 2$ ozs. $25 \mathrm{c} ; 1 / 4$ lb., $40 \mathrm{c} ; 1$ lb., $\$ 1.25$, postpaid.

\section{LEEK}

One ounce will sow 100 feet of row.

This belongs to the onion family, and is a good fall and winter substitute for green onions. The leaves are flat and the stems are very large, cylindrical and bulbous. Sow early in spring in drills 12 to 15 inches apart, covering $1 / 2$ inch deep, in good rich light soil. Thin plants to 6 inches apart in the row and draw the earth about them when cultivating.

IONDON FIAG-This well known broad. leaved leek is hardy, productive, of good qual. ity and is extensively cultivated in this coun. try and is a favorite sort with the market gardeners and is also extensively used for the home garden. Pkt.., 5c; 1 oz., 25c; 2 ozs., $40 \mathrm{c} ; 1 / 4$ lb., $65 \mathrm{c} ; 1$ lb., $\$ 1.95$, postpaid. 


\section{Cantaloupe or Muskmelon}

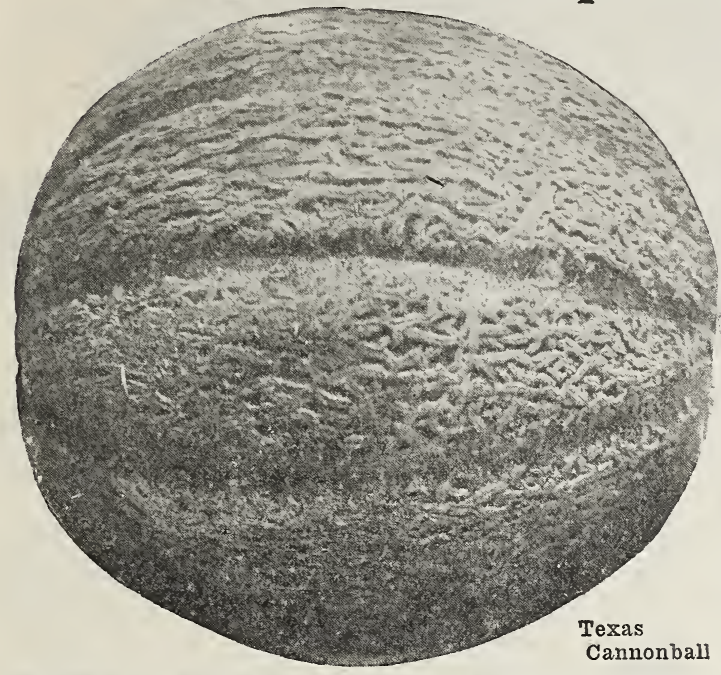

OSAGE or MIUIFR'S CREAIM-A favorite salmonfleshed variety. Large oval, slightly ribbed and netted; skin is very dark green; flesh is very thick and sweet flavored, most delicious to the rind. The whole crop is very even and fruit extra heavy, owing to this thickness of the flesh. A great favorite for both market purposes and the home garden especially. Pkt., 5c; oz., 15c; 2 ozs., $25 \mathrm{c} ; 1 / 4$ lb., $40 \mathrm{c} ; 1$ lb., $\$ 1.25$, postpaid.

NFW MUSRMHION POIIOCK, 10-25 - Salmon tint. The most popular of the Rocky Ford type melons among the western commercial growers. Introduced about two years ago, the stock has been controlled until now by a few ship. pers. Very uniform in highest quality; vigorous and early. Cuts with a golden center shading to a green at the rind. The latest and best Rocky Ford. Pkt., $5 \mathrm{c}$; oz., $15 \mathrm{c} ; 2$ ozs., $25 \mathrm{c} ; 1 / 41 \mathrm{~b}$. , $40 \mathrm{c} ; 1$ lb., $\$ 1.25$, postpaid.

NETIED ROCK-One of the most popular of the newer strains of shipping melons, and also highly esteemed on account of its rust-resisting qualities; is

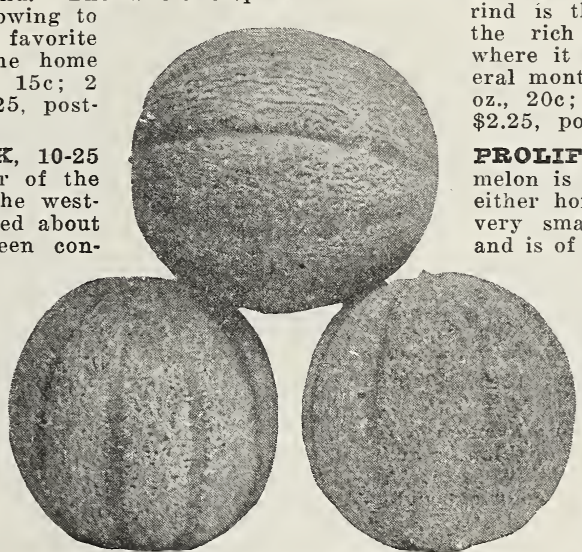
variety, of good size; noticeably ribbed and heavily netted. Pkt., 5c; 1 oz., 15c; 2 ozs. 25c; 1 lb., 35c; 1 lb., $\$ 1.25$, postpaid. rind is thin but tough and se close that he rich flesh is practically sealed up eral months after it is ripe. Pkt., 10c; 20c; 2 ozs.. 35c; 1/1 1b., 60c; 1 lb.

PROIIFIC NITITD NUTMEG-This elon is one of the very best varieties for use or the market. It has a ry uniform shape, average about inches. Pkt., 5c; 1 oz., 15c ozs., 25c; $1 / 4$ lb., 35c; 1 lb. $\$ 1.25$, postpaid.

BANANA - Shaped somewhat as name indicates; grows about $21 / 2$ feet long; flesh deep sal. mon colored and of only fair quality. Pkt., 5c; 1 oz., 20c; 2 zs., $35 \mathrm{c} ; 1 / 4$ lb., $50 \mathrm{c} ; 1 \mathrm{lb}$. $\$ 1.75$, postpaid.

BAITIMORY or ACME - A fine early, oblong, green-fleshed larger than the Rocky Ford, but not quite so early, although 30c; $1 / 4$ lb., 50c; 1 lb., \$1.75, postpaid.

TFXAS CANTONBAII-A perfectly round, green fleshed kind, a little larger than Rocky Ford. It is completely covered with netting and has no trace of ribs. It is early and its most remarkable feature is the thickness of flesh, which is not excelled by any other kind. Pkt., 5c; oz., 15c; 2 ozs., $25 \mathrm{c} ; 1 / 41 \mathrm{~b} ., 35 \mathrm{c} ; 1 \mathrm{lb}$., $\$ 1.25$, postpaid.

\section{MUSTARD}

One ounce will sow about 80 feet of drill.

For early salad sow in February and for general crop at intervals through the spring, in rows 6 inches apart, and rather thick in rows.

FIFPHANT GAR-Good market variety. Leaves are smooth, very large, and always tender and suc culent, makes a large plant. Pkt., 5c; 1 oz., $15 \mathrm{c} ; 2$ ozs., 20c; 1/4 lb.. 30c; 1 lb., $\$ 1.00$.

CHINrSE MAMMOTH-Light green, large leaves. Pkt., 5c; 1 oz., $10 \mathrm{c} ; 2$ ozs., $15 \mathrm{c} ; 1 / 4$ lb., 25c; 1 lb., 85c; 5 lbs., \$3.5 J, postpaid.

SOUTHERN GIANT CURIID-Leaves are large, light green with yellowish tinge, much crimped and frilled at the edges. Very succulent and of sweet flavor. Pkt., 5c; oz., 10c; 2 ozs., 20c; $1 / 4$ lb., 30c; 1 1b., $\$ 1.00 ; 5$ lbs., $\$ 4.00$, postpaid. pounds to the acre.

Melons thrive best in a light, rich soil. Plant late or early in May, when ground has become Previous to sowing seed mix a few shovelfuls of wellrotted manure in each hill, plant in each 12 to 15 most thrifty plants.

ROCKY FORD-This famous melon is known every where, and has been the standard ship type, medium size, oval, very sweet and fine tlavored; very prolific, and continues bearing enormous quanfor us at Rocky Ford, Colo., by an expert poses. The seeds are saved especially for seed pur. ppoul small or crate melons. The vines are vig. ribbed, densely covered with fine netting. Flesh light green, tinged with yellow, very sweet and highly lavored. The fruit is very uniform in shape and qual. 作 FOINEY DEW MTION-The delicious honez-like lavor of this new melon created a sensation wherever used last year. The fruit is of good size, weighing 6 to 8 pounds; light cream colored, smooth skin with thick, rich and sweet flesh of light green color. The

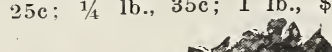




\section{Watermelons}

An ounce will plant 40 hills;

2 to 3 pounds will plant

an acre.

Watermelons delight in a light, sandy soil. Plant when danger from frost is over, in hills 8 to 10 feet apart each way. Put from 10 to 15 seeds in each hill and when well started thin out to the two best plants. In this latitude we plant the seed about the middle of April. The bugs will require careful watching or they will eat up the plants before they get tsarted. Do not make a big "hill"' when sowing the seed; it is much better to have the "hills" level with the surface of the ground.

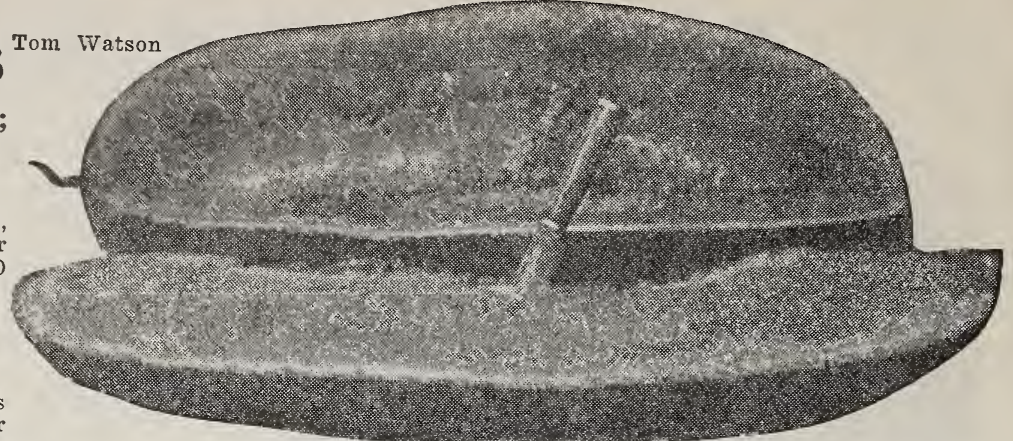

SFIFCTrD TOM WATSON-This is an extra selected stock of this splendid well-known and popular melon. Seed is saved only from specimen made as near uniform as possible. The grower will no doubt appreciate this from the fact that this stock will grow larger and more regular melons than the ordinary strain. We are pleased to offer this special stock this season, as we are sure you will be highly pleased with the results. Pkt., 5c; 1 oz., 15c; 2 ozs., $25 \mathrm{c} ; 1 / 4$ lb., $40 \mathrm{c} ; 1$ lb., $\$ 1.25 ; 5$ lbs., $\$ 5.50$, postpaid.

TOIM WATSON-Shape long, color of rind dark green, which is thin but very firm, making it a fine shipper. Flesh is bright red, firm and very sweet; has taken the lead over all other shipping melons. Pkt., 5c; 1 oz., $10 \mathrm{c} ; 2$ ozs., 15c; $1 / 4$ lb., 30c; 1 lb., 85c; 5 lbs., $\$ 3.00$, postpaid.

"IRISII GREY', WAPIRIIEION-The size of this melon is uniformly large and it closely resembles Kleckley's Sweets except the color, which is a yellowish gray. Flesh is very sweet and firm, without hard center, brilliant sparkling red. Rind almost as tough as a citron, making a grand shipper. Earlier than rom Watson. Irish Gray has instantly met with universal favor. Pkt. $5 \mathrm{c} ;$ oz., 15c; 2 ozs., $25 \mathrm{c} ; 1 / 4$ lb., 35c; 1 lb., $\$ 1.25 ; 5$ lbs., \$5.75, postpaid.

KIECKIEY'S SWEFT-This variety ripens early and is considered by many the sweetest, juiciest and most delicious of all. Specially fine for the home garden. The skin is dark green, faintly striped. Flesh bright red and peculiarly sweet, rich, crisp and of pleasing flavor. Pkt., 5c; oz., 10c; 2 ozs., 15c; 1/4 lb., $30 \mathrm{c} ; 1$ lb., $\$ 1.00 ; 5$ lbs., $\$ 3.75$, postpaid.

FAIBERT HONEY-The melons average eighteen to twenty inches long and are full or bluntly rounded at both ends. The skin is a dark, glossy green. The flesl is a beautiful crimson, the rich coloring and luscious quality extending to the thin rind. Pkt., $5 \mathrm{c} ;$ oz., $15 \mathrm{c}$; 2 ozs., 25c; $1 / 4$ lb., $40 \mathrm{c} ; 1$ lb., $\$ 1.25$, postpaid.

GEORGIA RATTIISNATE-The old standard variety, large, oblong, striped; flesh of fine quality. Pkt., $5 \mathrm{c}$; oz., 10c; 2 ozs., $15 \mathrm{c}$; $1 / 4$ lb., $25 \mathrm{c} ; 1 \mathrm{lb} ., 85 \mathrm{c} ; 5 \mathrm{lbs}$., $\$ 3.00$, postpaid.

BIACK DIAMOND-Immense in size, the common

weight of this melon is from sixty to eighty pounds. The rind hard and firm, which makes it superior for long distance shipping. In shape it is nearly round. Color solid dark green. Flesh deep red and fine quality. Pkt. $5 \mathrm{c} ;$ oz., $10 \mathrm{c} ; 2$ ozs., $15 \mathrm{c} ; 1 / 4$ lb., $25 \mathrm{c} ; 1$ lb., $85 \mathrm{c}$, postpaid.

SWEET IFART-Popular for market. Large heavy fruits of oval or round form; skin very pale green, with distinct netted lines of a slightly darker shade. The melons bear shipping well. The solid flesh is a deep red. Pkt., 5c; 1 oz., 10c; 2 ozs., 15c; $1 / 4$ lb., 25c; 1 lb., $75 \mathrm{c}$, postpaid.

GOIDIN IONEY-Flesh bright golden yellow, skin beautiful green, shaped slightly elongated. No melon is as sweet and delicious. Pkt., 5c; 1 oz., 15c; 2 ozs., 20c; $1 / 4$ lb., 35c; 1 lb., $\$ 1.00$, postpaid.

FARRIS' EARIIEST-Extra early; fruits large, slightly oval, with irregular, mottled, broad stripes of light and dark green; flesh bright red, sweet and tender. Seed black. Pkt., 5c; oz., 10c; 2 ozs., 15c; 1/4 lb., 30c; 1 lb., \$1.00, postpaid.

NFW WONDFRMEION-This new melon resembles the Tom Watson, but it is thicker, more solid and usually grows larger and heavier, growing uniformly large and long, not unusual for the melons to weigh 40 to 50 pounds and nearly all melons grow to a desirable size. The flesh is sparkling red and is sweet to the rind, even in smaller size melons. Rind is a dark glossy green with small crease-like markings on the larger sizes and is very attractive in appearance. Its eatings qualities are unexcelled; the luscious, large, deep red heart is sweet and melting, free of cores or hard centers, while the rind is thin yet it is tough enough that it will ship a reasonable distance with satisfaction. The seeds are pure white and few to the melon. It is a prolific melon and its appearance is a big selling point. It will pay to give this melon a trial. Pkt., 10c; oz., $20 \mathrm{c} ; 2$ ozs., $35 \mathrm{c} ; 1 / 4$ lb., $60 \mathrm{c} ; 1 \mathrm{lb}$., $\$ 2.00$, postpaid.

\section{MUSHROOM SPAWN}

Mushrooms can be grown in cellars, in sheds, in hotbeds, or sometimes in open air. Fermenting horse manure at a temperature of about 70 degrees, mixed with equal weight of fresh sod loam, is made into beds the size required, 8 inches deep. In this bed plant the broken $\mathrm{p}$ i e ces of spawn, 6 in. apart, covering the whole with 2 inches of light soil, a $n$ d protect from cold and rain. Price p e r brick, 40 cents; 5 b r i c ks, $\$ 1.75$, par: cel post paid. B $\mathbf{y}$ freight, per brick, $35 \mathrm{c}$; five b r i c k s $\$ 1.50$.

No other delicacy c a $\mathrm{n}$ compare with th e mushroom for cooking with meats of all kind. Start your bed this year. 


\section{ONION SEED and ONION SETS}

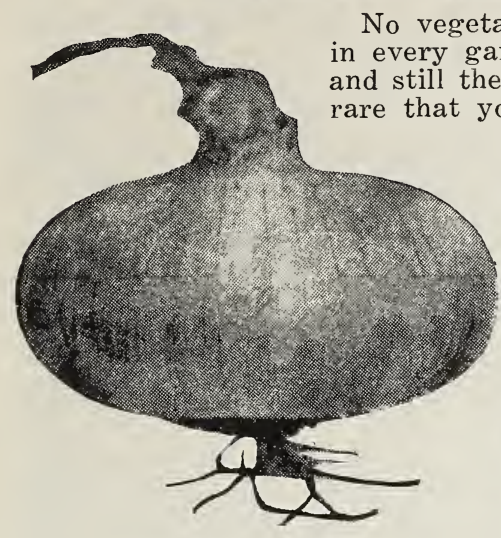

Crystal White Wax

\section{ONION SETS}

Plant the sets four inches af,art in rows about half an inch deep and one
foot between the rows, but do not cover the sets entirely. This applies to all varieties except the Potato Onion, which should be planted in rows 15 inches apart and 9 incehs apart in rows and then cover with about one inch of soil. All varieties can be set out in the fall as well as in the spring. Fall plantings of onions are succeeding very well in the South and should be more generally practiced.

WIITI SIIVIRSKIN1 qt., $25 \mathrm{c} ; 4$ qts., $85 \mathrm{c}$ postpaid.

RFD WPTHERSTIED -1 qt., $25 \mathrm{c} ; 4$ qts., $85 \mathrm{c}$, postpaid.

YEITOW DANVERS 1 qt., 25c ; 4 qts., $85 \mathrm{c}$, postpaid.

TETIOW POTATO - 1 qt., $40 \mathrm{c} ; 4$ qts., $\$ 1.25$, postpaid.

WHITE MULTIPIIFR SETS-1 qt., 40c; 4 qts., $\$ 1.25$, postpaid.

Onion Sets, for Quantity Prices See Page 49.

\section{HERBS SEEDS}

No garden is complete without a few Herbs planted in corners here and there that can can hardly be used for any other purpose. Order a few varieties with y'our garden seeds.

Sow seeds in shallow drill a foot apart, and when up thin out and transplant to a few inches apart.

Packet, parcel
post paid.

BASII SWEET-For flavoring soups_post paid. DILI MAMMOTH-Used for flavoring pickles

IAVENDIR-For oil and distilled water--

MARJORAIM, SWEFT-Used in seasoning meats ROSEMARY-Aromatic leaves ave used for

SAVORY, SUMMER-Used as a culinary herb BROAD IEAVED-A popular flavorSAGE, BROAD IEAVED-A popular flavor
ing plant TFYME-Much used for seasoning-...-..-

.10
.10
.10
.10
.10
.10
.10
widely grown as the onion and it deserves a place deep, rich soil, thoroughly worked is best for this crop. For large, as the weather opens and the sets are the size of a goose quill plant in th 12 inches apart and 4 to 6 inches between the onions. For main SOUTHPORT RED GLOBE-The finest type and most popular of and are excellent keepers; color a deep purplish red. Pkt., $5 \mathrm{c} ; 1$ oz.

IARGE RED WETHERSFIEXI-A fine. large, rather flat sort, of a deep purplish-red color; noted for its productiveness and keeping qual BERIIUDA-In shape and size, also in flavor, exactly like Yellow PRIZETAKre-One of the largest onions grown and the mildest; is productive and a sure cropper; bulbs are globe-shaped and of light straw olor. Pkt., 5c; 1 oz., 25c; 2 oz., $45 \mathrm{c} ; 1 / 4$ lb., $75 \mathrm{c} ; 1$ lb., $\$ 2.50$, YELIOW GIOBE DANVERS-Bulbs me-
dium to large size, uniformly globe shaped; skin rich coppery yellow; flesh creamy white, crisp and mild. Pkt., 5c; oz., 25c; 2 oz., $40 \mathrm{c} ; 1 / 1 \mathrm{lb}$., $75 \mathrm{c} ; 1$ lb., $\$ 2.50$, postpaid.

SOUTHPORT WHITE GIOBEOne of the best of the Globe varieties. Large in size, fine in quality, bringing a ready sale anywhere. Color a silvery white. When sown thick they can be used for green or bunch onions. Our strain of this seed is of a fine quality. Pkt., 5c; 1 oz., 30c; 2 oz. $50 \mathrm{c} ; 1 / 4$ lb., $85 \mathrm{c} ; 1 \mathrm{lb}$. $\$ 2.85$, postpaid.

CRYSTAI WHITE WAX -Earliest of the Bermuda varieties; makes large, flat onions so mild and sweet that they can be eaten like apples. Pkt., 5c; 1 oz. $50 \mathrm{c} ; 2$ ozs., $90 \mathrm{c} ; 1 / 4 \mathrm{lb}$. $\$ 1.75 ; 1$ lb., $\$ 6.50$, post paid.

WHITE SIIVIR SKIN Southport - This is a superior stock. Red Globe Its delicate, mild flavor, stately form, large, handsome size, pure white color make it a most wonderful variety for the table, the most profitable for market and shipping. Plants are of an extremely thin neck and sure to ripen early; should be harvested as soon as ripened and dried in the shade to preserve their silvery white skin. Pkt., $5 \mathrm{c}$; oz., $30 \mathrm{c} ; 2$ oz., $50 \mathrm{c}$; $1 / 4$ lb., $85 \mathrm{c} ; 1$ lb., $\$ 2.85$, postpaid.

\section{FOR OUANTITY FRICES ON ONION SETS SEP PAGE 49 .}

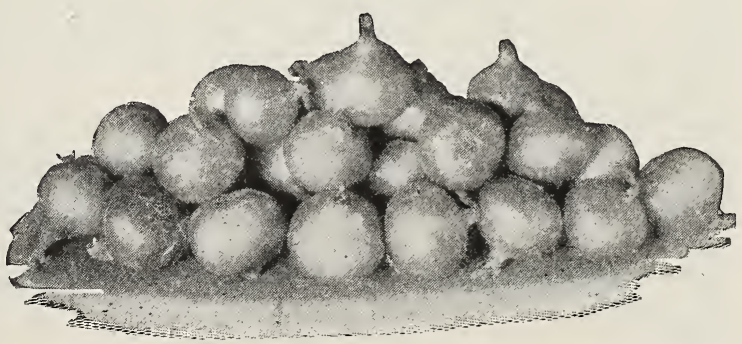

White Silverskin Onion Sets 


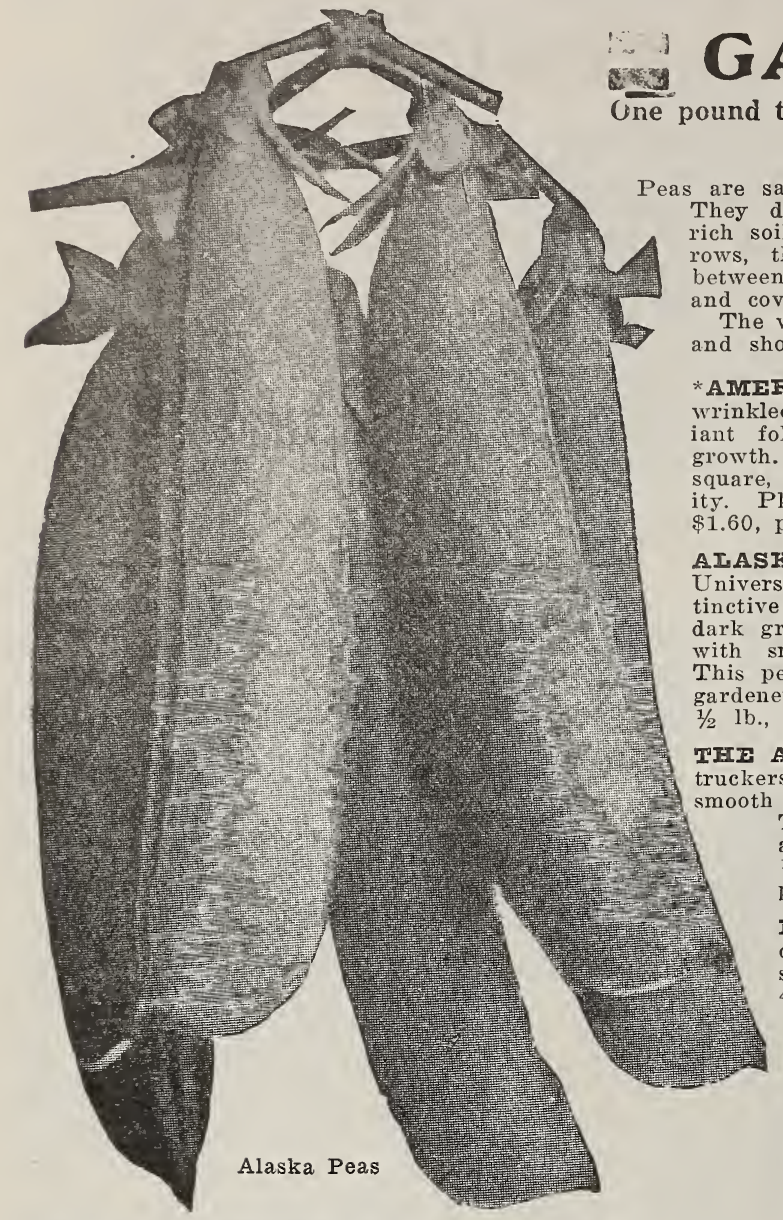

*GRADUS or EROSPERITY (Wrinkled)-This is the earliest large podded pea in cultivation. The peas are tender and sweet, of extra large size pods, averaging 4 to $4 \frac{11}{2}$ inches long and contain from eight to ten peas of enormous size and excellent quality. Pkt., 10c; 1/2 1b., 20c; 1 lb., 40c; 2 lbs., $75 \mathrm{c}$; 5 lbs., $\$ 1.65$, postpaid.

*TrIEPIONE-A large podded pea for general crop. The vines are very strong in growth and average 18 to 20 pods per stalk; the pods are of large size, containing 6 to 7 peas each, which are of a pale green color, closely packed in the pod, and of a most delicious flavor; height $3 \frac{1 / 2}{2}$ feet. Pkt., 10c; $1 / 2 \mathrm{lb}$., 20c; 1 lb., 40c; 2 lbs., 75c; 5 lbs., $\$ 1.65$, postpaid.

*THOIMAS IAXTON PEAS-Popular early market sort. Pods large, deep rich green, filled from end to end with plump peas. Vines grow from 3 to $3 \frac{1}{2}$ feet high. The seed is wrinkled, so don't plant until March. Pkt., 10c; 1/2 lb., 20c; 1 lb., 40c; 2 lbs., 75c; 5 lbs., $\$ 1.65$, postpaid.

MFITING SUGAR (Edible Pods)-We consider this the best of the edible-podded sorts, in which the pods are used when half grown and are cooked in the same way as snap beans. The pods of Melting Sugar are very lirge, 4 to $5 \frac{1 / 2}{2}$ inches long, broad, often curved or twisted, and when young stringless, very tender, finely flavored. The variety we offer, sometimes called Mammoth Melting Sugar, is rather late maturing, very prolific, strong growing, about four to five feet high, with large light colored foliage. Pkt., 15c; $1 / 2$ lb., 25c; 1 lb., 50c; 2 lbs., $90 \mathrm{c}$; 5 lbs., $\$ 2.00$, postpaid.

*IAXTONIAN-Largest podded variety of extra earlies; 18 inches high; quality equaling the Gradus. Pkt., 10c; $1 / 2$ lb., $20 \mathrm{c} ; 1$ lb., $40 \mathrm{c} ; 2$ lbs., 75c; 5 lbs., \$1.65, postpaid.

IARGE WHITE IMAEROWFAT (Not Wrinkled)-Tall, vigorous growing, prolific; pods large, good quality. Pkt., 10c; $1 / 2$ lb., 20c; 1 lb., 35c; 2 lbs., $65 \mathrm{c} ; 5$ lbs., $\$ 1.50$, postpaid.

*CHAMPION OF ENGIAND-Vines 4 to 5 feet high, foliage medium green; pods broad and nearly straight, 3 inches long. Pkt., 10c; $1 / 2$ lb., 20c; 1 lb., 40c; 2 lbs., $70 \mathrm{c} ; 5$ lbs., $\$ 1.60$, postpaid.

Quantity Prices on Peas, See Page 49

\section{EN PEAS}

pounds.

e to sow as early as the ground can be worked. (nelect a light, not too , or they will run to vine too much. Sow double
ese to be 6 inches apart and $2 \frac{1 / 2}{2}$ to $3 \frac{1 / 2}{2}$ feet the double rows,

wrinkled sorts marked $\left({ }^{*}\right)$ are more sensitive to cold

ICAN WONDER-The earliest of the dwarf ; vigorous and productive, with dark, luxurVines dwarf, 12 inches high, of compact ods $2 \frac{1}{2}$ inches long, round, appearing almost and crowded to the end with peas of excellent qual. postpaid$$
\text { ; } 1 / 2 \mathrm{lb} ., 20 \mathrm{c} ; 1 \mathrm{lb} ., 40 \mathrm{c} ; 2 \mathrm{lbs} \text {., } 70 \mathrm{c} ; 5 \mathrm{lbs} \text {. }
$$

his is the earliest of all small podded peas. ally used for first planting; the vines are a dislight green, and from 2 to 3 feet high. Pods are all, smooth blue-green peas of excellent flavor. s. Requires about 60 days to mature. Pkt., 10c;
$20 \mathrm{c} ; 1$ lb., 40c; 2 lbs., $70 \mathrm{c} ; 5$ lbs., $\$ 1.60$, postpaid. AMEER or IARGE AJASKA-Very popular with in certain sections of the South. The peas are The season is early, 2 to 3 days later than Alaska. and the pods are almost twice as large. Pkt., 10c: $1 / 2$ lb., 20c; 1 lb., $40 \mathrm{c}$; 2 lbs., $75 \mathrm{c} ; 5$ lbs., $\$ 1.65$. postpaid.

F"IEST AND BEST-Earliest and most even strain of white, extra early peas; often a single picking will secure entire crop. Pkt., 10c; 1/2 lb., 20c; $1 \mathrm{lb}$., $40 \mathrm{c} ; 2$ lbs., 70c; 5 lbs., $\$ 1.60$, postpaid.

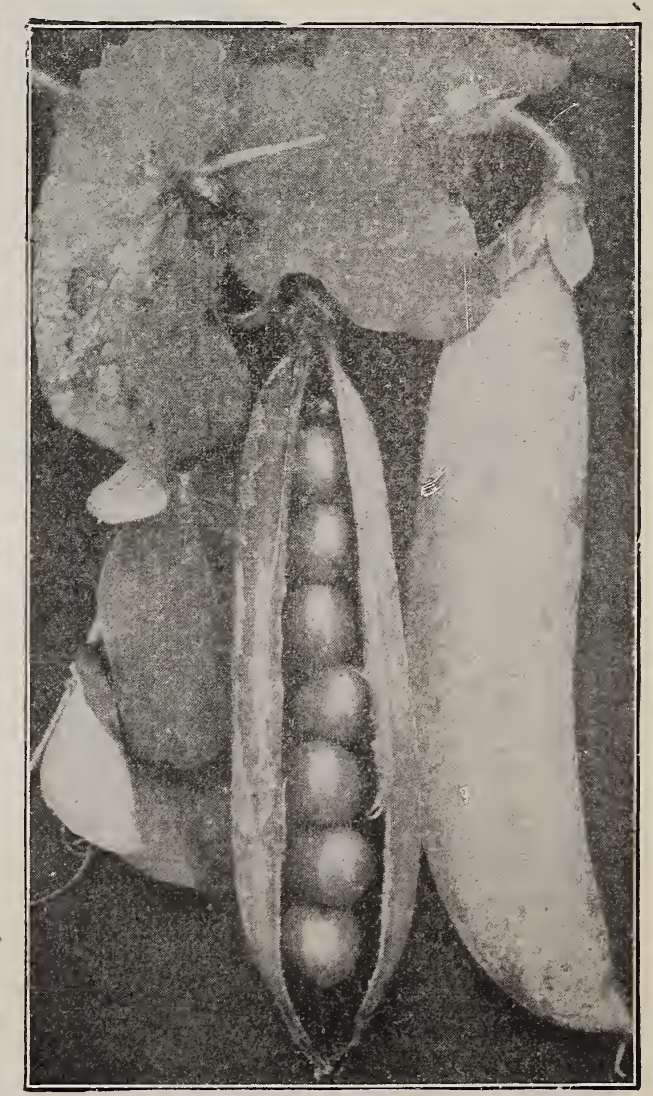

Telephone Peas 


\section{QUALITY PEPPERS One ounce will produce about}

Sow in hotbed in March and transplant to the open ground as soon as the weather is warm and settled. Set in 3-foot rows and about 2 feet apart Cultivate well and keep free from weeds.

CRIMSON GIANI-An early matur ing large sized sweet pepper, similar in shape to Chinese Giant, but much longer and flesh thicker. It is excep tionally mild and very prolific; earlier than the Clinese Giant. Pkt., 5c; 1/ oz $30 \mathrm{c} ; \mathrm{Oz}, 50 \mathrm{c} ; 2$ ozs. $85 \mathrm{c} ; 1 / 1$ lb., $\$ 1.50 ; 1$ lb., $\$ 5.50$, postpaid.

BEIT or BUII NOSF-The plants are vigorous, about two feet high, compact and very productive, ripening their crop uniformly and early. The fruits are large, with thick, mild flesh of excellent quality for use in salads and mangoes or in stuffed peppers. The color is deep green when fruit is young, bright erimson when ripe. Pkt. $5 \mathrm{c} ; 1 / 20 \%, 20 \mathrm{c} ; 1$ oz., 35c; 2 ozs., 50c; 1/4 lb., $\$ 1.00$; 1 lb., $\$ 3.50$, postpaid.

RUEY KING-A large sort, $4 \frac{1}{2}$ to 6 inches long, and $3 \frac{1}{2}$ to 4 inches thick. Color a ruby red at maturity excellent quality. Among the best sorts for pickling. Used for stuffing. Pkt., 5c; $1 / 2$ oz., 20c; 1 oz., $35 \mathrm{c}$; ozs., $50 \mathrm{c} ; 1 / 4$ lb., $90 \mathrm{c} ; 1$ lb. $\$ 3.50$, postpaid.

CHINEST GTANT-Plant dwarf, fruit of mammoth size, very broad but rather short. It is very late and a rather shy yielder. Popular on account of its large size and mild flavor. Pkt., $5 \mathrm{c} ; 1 / 2$ oz., $25 \mathrm{c} ; 1$ oz., $45 \mathrm{c} ; 2$ ozs., $80 \mathrm{c} ; 1 / 4$ lb., $\$ 1.50 ; 1$ lb., $\$ 5.00$, postpaid.

\section{PIMENTO or PEREFCTION}

-This is the sweetest pepper grown, as it does not contain the slightest trace of fieryness. The plants are extremely productive, and peppers are medium in size and of a shape which is desirable for filling, and when prepared in this manner they are delicious. It may be used in preparing salads and for flavoring. in which case it will add a fresh and delightful flavor. The flesh is quite thick and the pepper may be scalded for peeling the skin off. When fully ripe the peppers are of a brilliant red color and very attractive. Pkt. $5 \mathrm{c} ; 1 / 2$ oz., $15 \mathrm{c} ; 1$ oz., $25 \mathrm{c} ; 2$ ozs., $40 \mathrm{c} ; 1 / 4$ 1b., $75 \mathrm{c}$ 1 lb., $\$ 2.50$, postpaid.

IONG RED CAYENNE-The well-known favorite hot pepper; fruits conical-shaped 3 to 4 inches long of bright red color, and are borne in great profusion. Very pro lific for so large a pepper. Matures in about 125 days. Pkt., 5c; $1 / 2$ oz., $25 \mathrm{c} ; 1$ oz., $35 \mathrm{c} ; 2$ ozs., $60 \mathrm{c} ; 1 / 41 \mathrm{~b}$. $\$ 1.00 ; 1$ lb. $\$ 3.50$, postpaid.

BIRD'S EYI or CREOIE-Very hot; used for pepper vinegar. Pkt., 10c; oz., 50c; 2 ozs., 90c; $1 / 41 \mathrm{~b}$., $\$ 1.75$, postpaid.

TABASCO-Very ungent and strong. Pkt., 10c; oz., $50 \mathrm{c} ; 2$ ozs., $90 \mathrm{c} ; 1 / 1 \mathrm{lb}$., $\$ 1.75$, postpaid.

RID CIIII-Small and very pungent, used for chili sauces. Plkt., $10 \mathrm{c} ; 1 / 2$ oz., $35 \mathrm{c} ; 1$ oz. $50 \mathrm{c} ; 2$ ozs., $90 \mathrm{c}$; $1 / 4$ 1b., $\$ 1.75$, postpaid.

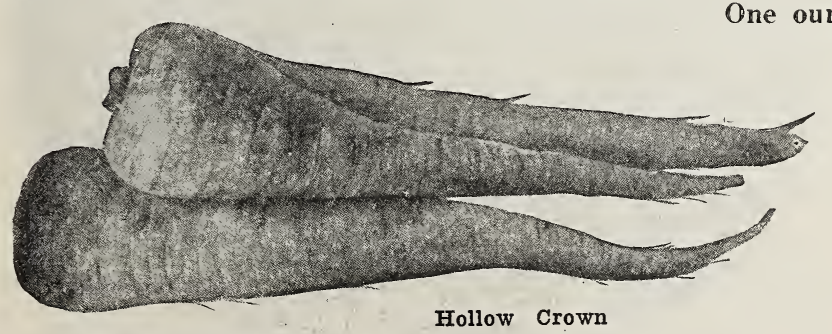

Hollow Crown

1 ounce to 100 foot row; about 8 pounds to acre.

Extensively grown in the South, and should be better known, as it is a delicious vegetable. The young green pods make a healthful and delicious soup and, when picked, are a fine salad. Sow after the weather has become warm in rows 3 feet apart, 2 feet apart in the rows. Will succeed in any good garden soil.

WITVE? VIIVET-Bears round. white, smooth pods, unlike other varieties, which are ridged or square-edged. Pods are large and are produced in great abundance. The market gardeners' favorite. Pkt. 5c: 1 oz. $10 \mathrm{c} ; 2$ ozs., $15 \mathrm{c} ; 1 / 1 \mathrm{lb} ., 25 \mathrm{c} ; 1 \mathrm{lb}, 65 \mathrm{c} ; 5$ lbs., $\$ 2.85$, postpaid.

PRRIIN'S IM A IMI IL T H IONG POD-This variety is about three feet high, very early and productive. Pods deep green, very long, slender, slightly corrugated, very ten. der and of good quality. Pkt. c. $0 \mathrm{z}, 10 \mathrm{c} ; 2$ ozs, $15 \mathrm{c} ; 1$ lb., $65 \mathrm{c} ; 5$ lbs., $\$ 2.85$. postpaid. FARIY DWARE GREENOf. dwarf growth but im.

Laige Doubla

Curled Parsley mensely productive. ity, and are borne throughout the season Plest $5 \mathrm{c}$ oz, 10c; 2 ozs, $15 \mathrm{c} ; 1 / \mathrm{l}$ lb, 25c; 1 lb, 65c; 5 lbs. $\$ 2.85$, postpaid.

\section{PARSLEY}

One ounce will sow 150 feet of drill.

IARGE DOUBLE CURLED-This is an excellent variety, dwarf in habit; grows very compactly and stands the winter better than the plain. Leaves crimped or curled and used principally as a garnish for the table. Pkt., 5c; oz. $10 \mathrm{c} ; 2$ ozs., $15 \mathrm{c} ; 1 / 4$ lb., $25 \mathrm{c} ; 1$ lb., $75 \mathrm{c}$ 5 lbs., $\$ 3.50$, postpaid.

PIAIN or SINGIE-Dark color; very hardy; much used for flavoring. The leaves are plain or smooth. Pkt.

$5 \mathrm{c} ; 0 z ., 10 \mathrm{c} ; 2$ ozs., $15 \mathrm{c} ; 1 / \mathrm{l}$ lb., 30c; 1 lb., 90c, postpaid.

\section{PARSNIPS}

One ounce will sow 200 feet of drill; 5 pounds required for one acre.

Like all root crops, they do best on deep, rich, sandy soil, but will make good roots on any soil that is deep and mellow. In drills 2 to $2 \frac{1 / 2}{2}$ feet apart; cover with $1 / 2$ inch soil and press the seed down firmly. Thin the plants to 5 or 6 to the foot; cultivate frequently during the summer to insure rapid growth. In fall the roots may be taken up and stored in root cellars or pits for winter use.

SUGAR or HOILOW CROWN-Pkt. $5 \mathrm{c} ;$ oz., $15 \mathrm{c} ; 2$ ozs., $25 \mathrm{c} ; 1 / 4$ lb., $30 \mathrm{c} ; 1$ lb., \$1.00, postpaid. 


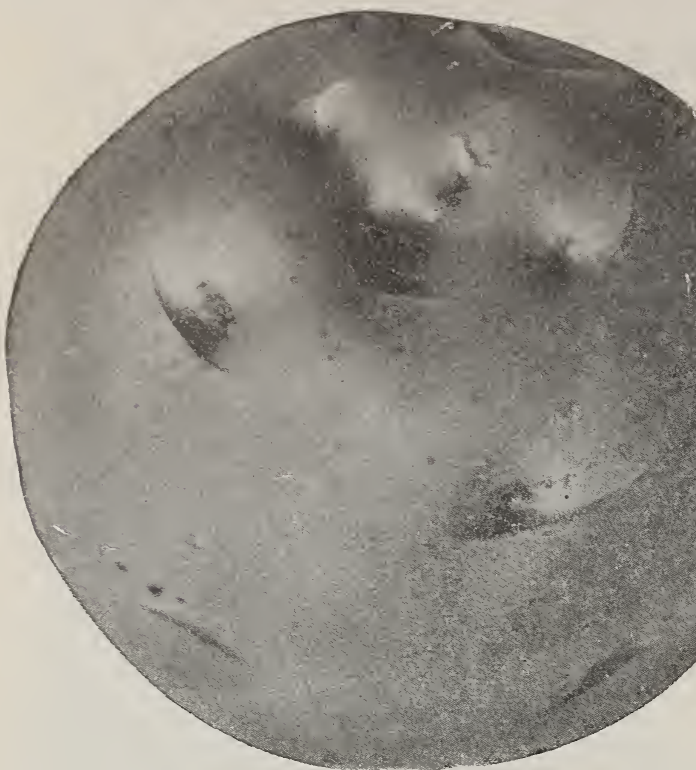

Lookout Iountain Potaio

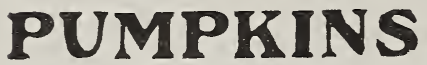

One ounce will plant about 25 hills, 5 pounds to the acre.

The pumpkin under good care bears abundantly, and furnishes a great amount of palatable food for cows, pigs, etc. Several of the finest flesh varieties are also used for culinary purposes. They may be grown as a field crop. Plant in hills 8 feet apart each way, and any time after the first of May. Avoid planting near other vine crops, as they will hybridize, and damage that crop.

KMNTUCKY FIEID-A very popular Southern sort large and flattened. A wonderful keeper. A good stock variety; also a valuable eating and pie sort. Pkt., 5c; oz., 10c; 2 ozs., 15c; 1/t 1b., 20c; 1 lb., $50 \mathrm{c}: 5$ ibs., $\$ 2.00$, postpaid.

STRIPED CUSHAW-This pumpkin is of the crookneck type with mottled green and white stripes. The neck is rather small. Fruit often attains a weight of 15 pounds; flesh is yellow, very solid and fine-grained. An excellent variety for culinary purposes. Pkt., 5c; 1 oz., 15c; 2 ozs., $25 \mathrm{c} ; 1 / 4 \mathrm{lb} ., 40 \mathrm{c}$ 1 lb., $\$ 1.25$, postpaid.

KING OF MAIMMOTH-Giant among pumpkins; specimens have keen grown to weigh 250 pounds and reaching 2 feet or more in diameter. Fruits are almost round, skin orange-colored and slightly rough. Flesh deep and yellow quality excellent. A fine variety to plant where only a few hills are wanted. Pkt., 5c; 1 oz., 15c; 2 ozs., 25e; $1 / 4$ lb., 50c: 1 lb., $\$ 1.50$, postpaid.

TENNESSEE SWEET POTATO-Of medium size, creamy white, with light green stripes and fine grained brittle flesh. Pkt., $5 \mathrm{c} ;$ oz., $15 \mathrm{c} ; 2$ ozs., $25 \mathrm{c} ; 1 / 4$ lb., $35 \mathrm{c} ; 1 \mathrm{lb}$. $\$ 1.25$, parcel post paid.

JAPANESE PIE-Shaped somewhat like the Cushaws and grows to a large size; skin deep green with dark stripes and rough ridges on the neck; flesh deep wellow and of the highest quality; seeds sculptured like Chinese letters. This is one of the best varieties to plant for home use. Pkt., 5c; 1 oz, 15c; ozs., $25 \mathrm{c} ; 1 / 4$ lb., $40 \mathrm{c}$; 1 lb., $\$ 1.25$, postpaid.

For Quantity Prices on All Vegetable and Field Seeds, See Colored Insert.

\section{SEED POTATOES}

One peck will plant 125 feet of row; 8 to 10 bushels will plant 1 acre.

The land should be gotten into fine mellow condition. Mark it off into rows 3 feet apart and run a furrower along so as to make a furrow about four inches deep. Apply Truck Fertilizer along this furrow with a distributor or by hand. The furrower should be run along $2 \frac{1}{2}$ inches deep, after the fertilizer is applied, to mix it with the soil. Drop the seed 15 inches apart and cover with a cultivator ar ranged to throw the earth back into the fur row. Cultivate frequently after the potatoes come up, and do not "hill up" more than just enough to cover the potatoes which form near the surface. If there is danger of frost soon after the potatoes come up, they may be covered with earth without injuring them at all.

FARLY RED TRIUIMPH-Extremely prolific and extra early, the color a beautiful light red; medium size. Growth very uniform, nearly round. Flesh white; mealy when cooked. Eyes slightly depressed, skin smooth. Its beauty, quality, extreme earliness and great productiveness make it very profitable.

IRISF COBBIFR-This is one of the most reliable and is fast becoming one of the most popular of the early varieties for a white skin potato in the South. It is of a handsome cream-white color and of excellent quality, making it most desirable for the best trade. It is a vigorous grower, ripens uniformly and is a good keeper. In fact it is one of the best all-around early potatoes now on the market.

EARIY OHIO-This is one of the standard varieties, and is credited with being the very earliest potato on the market. It matures a week earlier than the Early Rose. The tubers average large in size, are oval, oblong and round at seed end. A fine yielder, but does best for planting in loamy or stiff soils. Irish Cobbler seems to do best in light or sandy soils.

IOOKOUT MOUNTAIN-Very prolific, late; long keeping variety, for planting in June and July; grows large tubers, pure white; smooth, of good quality. No other variety stands our hot climate as well. We book orders now for shipment in June. Prices on application.

For prices on Irish Potatoes see Prices, Page 49

\section{SEED SWEET POTATOES}

All Sweet Potatoes will be shipped about the middle of March The weather before that time is entirely too cold to ship. We ship in good condition, and do all in our power to get them to you in good order. Sweet Potatoes are poor shippers. Our responsibility ceases upon our delivery to the railroad company. We will not be responsible ior delars or damaged conditions on arrival. NANCY HAII-Skin yellow; meat, which is clear amLer color, is as sweet as honey.

PORTO RICO YAIM-Skin golden; meat deep orange yellow; tu.

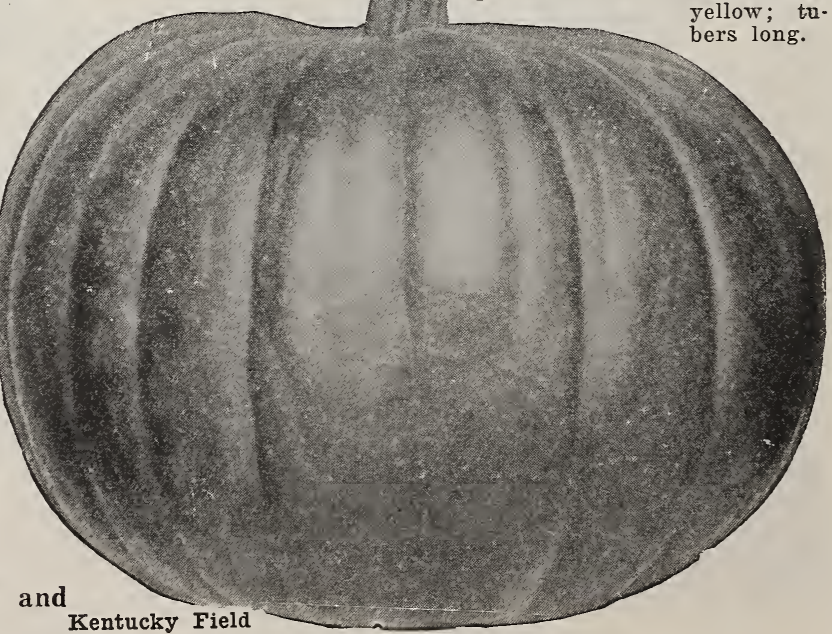




\section{RADISHES}

One ounce of seed will sow 100 feet of drill, 10 or 12 pounds to the acre.

Sow in January or February in hotbeds, and they must have plenty of ventilation and moisture. Out of doors, sow from March to September. Radishes must be grown quickly to be tender and crisp, and quick growth requires rich soil and plenty of moisture.

EARIY SCARIET TURNIP-A round, red, turnip shaped radish with small tops of very quick growth, deserving general cultivation on account of its rich, scarlet-red color, almost crimson, and its white, crisp, tender flesh; the roots often grow one inch long by one and oneeighth inches in diameter before coming pithy Pkt., 5c; oz., 10c; 2 ozs., 20c; 1/t lb., 30c; lb., $90 \mathrm{c} ; 5$ lbs., $\$ 4.00$, postpaid.

\section{FRENCF BREAKEAST-A quick} growing, small, olive-shaped radish, about three and one-half inches long by five-eighths to three-fourths of an inch in diameter when fully grown. The color is a beautiful deep rosescarlet except a little clear white about the tip. Pkt., $5 \mathrm{c}$; oz., $10 \mathrm{c} ; 2$ ozs., $20 \mathrm{c}$; $1 / 4$ lb., 30c; 1 lb., 90c; 5 lbs., $\$ 4.00$, postpaid.

EARIY SCARIET T UR NIP, WHITE TIPPED-One of the handsomest of the turnip radishes, and a great favorite. Color very deep scarlet with a distinct white tip; flesh white. Pkt., 5c; 1 oz., $10 \mathrm{c} ; 2$ ozs., $15 \mathrm{c} ; 1 / 1$ lb., 25c; 1 lb., 80c; 5 lbs., $\$ 3.50$, postpaid.

CHINA ROSE WINTER-One of the very best for fall and winter use, bright rose color, flesh white and firm, superior quality. Pkt., $5 \mathrm{c}$; oz., $10 \mathrm{c} ; 2$ ozs., $20 \mathrm{c}$; 1/t/ lb., 30c; 1 lb., 90c, postpaid.

ROUND BIACK SPANISH WINTER-Large, black-skinned radish. Pkt., 5c; oz., 10c; 2 ozs., $20 \mathrm{c} ; 1 / 4 \mathrm{lb}$., $30 \mathrm{c} ; 1 \mathrm{lb} ., 90 \mathrm{c}$, postpaid.

\section{IONG BIACK SPANISH WINTER} -Like the above, but the roots are longer and somewhat milder in flavor. Pkt., 5c; oz., 10c; 2 ozs., 20c; $1 / \mathrm{l} \mathrm{lb}$. 30c; 1 lb., 90c, postpaid.

WHITE ICICIE-One of the best early long, white sorts, suitable either for forcing or growing outside. Roots somewhat shorter and tops smaller than White Vienna. Very crisp and tender and of a beautiful waxy white color. Pkt., 5c; 1 oz., $10 \mathrm{c} ; 2$ ozs., 20c; $1 /$ lb., 30c; 1 lb., 90c, postpaid.
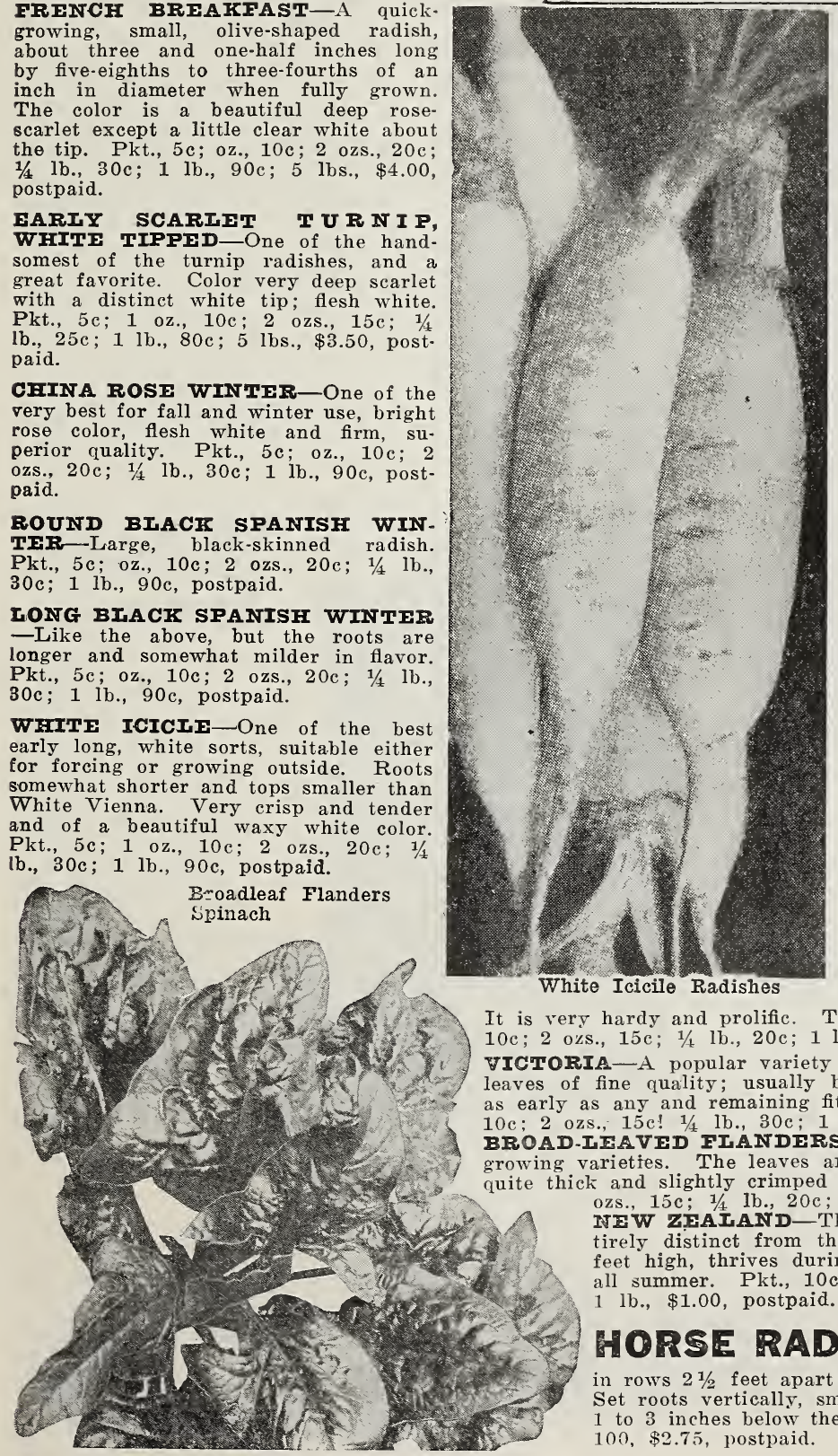

French Breakfast Radishes

TONG SCARIET SHORT TOPThe best of the long red radishes. It is very early, of good size, fine quality; most largely planted of all long red radishes. Pkt., 5c; 1 oz. $10 \mathrm{c} ; 2$ ozs, 20c: 1/1 lb, 30c: $1 \mathrm{lb}$. $90 \mathrm{c} ; 5$ lbs., $\$ 3.75$, postpaid.

COOPER'S SPARILER, WHITE TIPPIDD-A comparatively new variety. Globular in shape, rosy carmine, with white tip. Solid and crisp; very short top. This is a splendid variety and very popular on many markets. Pkt., 5c; 1 oz., $10 \mathrm{c}$ 2 ozs., $20 \mathrm{c} ; 1 / 4$ lb., 30c; 1 lb., 90c; 5 lbs., $\$ 4.00$, postpaid.

FARIY WHITE TURNIP-A turnip-shaped white radish. Its color is pure white, almost crystal, so clear and transparent. Its quality is excellent. It is of a turnip shape, has a short top, is very rapid growing Pkt., 5c; 1 oz., 10c; 2 ozs., 20c $1 / 4$ lb., 30c; 1 ib., 90c, postpaid.

\section{SPINACH}

One ounce to $100 \mathrm{ft}$. row; 10 to 12 pounds per acre.

Requires a very rich, loose, moist soil. Spade or plow undert frell rotted manure in the fall. For spring culture the rows should be 12 to 18 inches apart and thin to about six inches between plants. Spinach can be sown in the fall for early spring use. Cover seed-bed with straw, leaves, etc.

BIOOMSDAIE SAVOY IEAVED -A valuable variety with wrinkled leaves, resembling the Savoy Cabbage. ver. hardy and prolific The most popular sort. Pkt., 5c: $1 \mathrm{oz}$., 作 fine quality; usually blunt or rounded at the ends. About . $15 \mathrm{c} ! 1 / 4$ lb., 30c; $1 \mathrm{lb}, 60 \mathrm{c}$, postpaid.

Thest vigorous and strong round, uniformly deep green ozs., 15c; 1/4 lb., 20c; 1 lb., 50c, postpaid. NEW ZWAAND-This is a plant of a different genus; en. tirely distinct from the common Spinach. It grows 4 to 5 feet high, thrives during the hot weather; can be cut nearly all summer. Pkt., $10 \mathrm{c} ; 1$ oz., $20 \mathrm{c} ; 2$ ozs., $30 \mathrm{c} ; 1 / 1 \mathrm{tb}$., $40 \mathrm{c}$; 1 lb., $\$ 1.00$, postpaid.

HORSE RADISH Grown from pieces of the in rows $2 \frac{1}{2}$ feet apart and about 18 inches apart in the row. Set roots vertically, small end down, and the top of the root 1 to 3 inches below the surface of the ground. Doz., $50 \mathrm{c}$; per $100, \$ 2.75$, postpaid. By express, doz., $40 \mathrm{c} ; 100$ for $\$ 2.50$. 


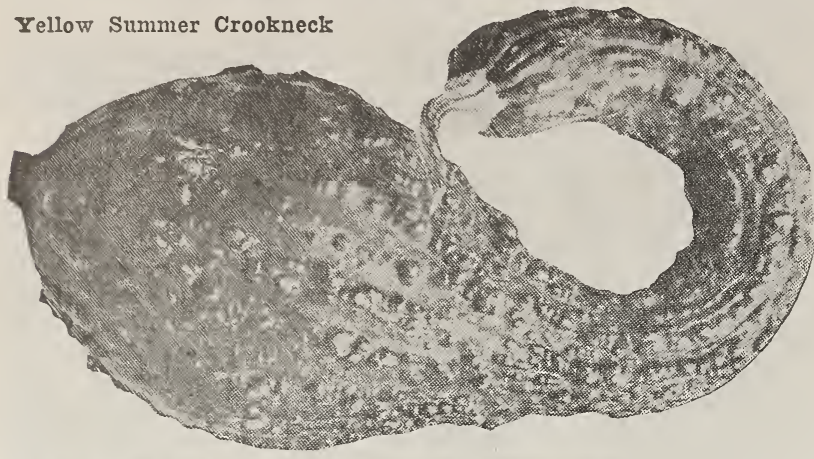

\section{SQUASH}

One ounce for 50 hills. About 4 pounds to an acre.

Squash does best in a good, rich soil. Sow in hills 4 to 5 feet apart for summer squash. Sow 8 to 10 seeds in a hill, thinning to the five strongest plants. Winter varieties need 6 to 8 feet between hills.

IFARIY WIITIE BUSII-An early round, flat squash; color clear white; handsomely scalloped; sometimes called "Patty-Pan." Is one of the best early summer squashes. Pkt., $5 \mathrm{c}$; 1 oz., 15c; 2 ozs., $25 \mathrm{c}$; $1 / 4$ lb., $40 \mathrm{c} ; 1$ lb., $\$ 1.25$; 5 lbs., $\$ 5.50$, postpaid.

BOSTON MARROW-A very productive fall or winter variety of medium size, oval shape and thin skin, used largely for canning and for pies. Fruits are bright orange color with a

SWISS CHARD OR SPINACM BEET

One ounce to 100 feet row.

Swiss Chard requires a rich soil and should be planted early. Sow in rows 18 inches apart, about 1 inch deep and thin the plants to 4 to 6 inches in the row. Swiss Chard does not produce an edible root like the regular garden beet, but is highly esteemed for the broad, white leaf stalks and midribs, which are cooked and served in the same manner as asparagus, making a most delicious vegetable. The leaves are also cooked like Spinach and considered equally palatable. Two d is $\mathrm{t}$ i $\mathrm{n}$ ct dishes may thus be grown from one plant at the same time. Should be in every home garden.

IUCUIIUS-A new variety, stalks as thick and broad as rhubarb and leaves light green, much crumpled and curled. Pkt., 5c; 1 oz., 10c; 2 ozs., 20c; $1 / \frac{1}{5}$ lb., 30c; 1 lb., \$1.00; lbs., $\$ 4.50$, postpaid.

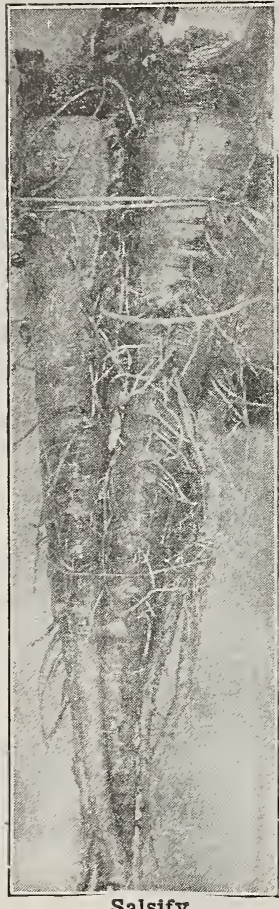

Salsify

\section{SORREL}

A hardy plant-grown for its leaves, which are used as boiling "greens" or salad, also for making soup. Seed should be sown thinly, in drills, early in spring. When well started, thin to stand 4 to 6 inches apart in the row. The leaves can be gathered for use at any time after the plants are well started in growth, and the roots will continue to produce a further supply. LARGP IEAVED FRENCH-Pkt., 10c; 1 oz., $35 \mathrm{c} ; 2$ ozs., $60 \mathrm{c}$

\section{RHUBAR}

Rhubarb roots for setting out can be easily grown from seed in a single season. The seed should be sown in shallow drill or seed bed in the spring, using 1 ounce to 125 feet of drill. When well started, thin to stand 10 to 12 inches apart. Cultivate well. The stalks should not be cut before the third vear. For immediate use order roots which come into use at once.

VICTORIA SEED-The most popular va riety. Pkt., $5 \mathrm{c} ; 1$ oz., $30 \mathrm{c}$, postpaid.

RHUBARB ROOTS-We can supply fine roots of above variety. 1-year roots each $20 \mathrm{c}$ doz., $\$ 1.75$. 2-year roots each $40 \mathrm{c}$; dozen $\$ 3.00$, postpaid. Not prepaid, 1-year roots each $15 \mathrm{c}$; doz. $\$ 1.25$; 2-vear roots, each $35 \mathrm{c}$; dozen, $\$ 2.50$. light shading of eream. Pkt., $5 \mathrm{c} ; 1$ oz., $15 \mathrm{c} ; 2$ ozs., $25 \mathrm{c}$; $1 / 1$ lb., 40c; 1 lb., $\$ 1.25$, postpaid.

FUBBARI-An old favorite; shell a very dark green smooth and exceedingly hard. Flesh deep orange color and very thick; splendid for baking or pies. Pkt., $5 \mathrm{c} ; 1 \mathrm{oz}$. $15 \mathrm{c} ; 2$ ozs., $25 \mathrm{c} ; 1 / 4$ lb., $40 \mathrm{c} ; 1$ lb., $\$ 1.25$, postpaid.

ITAIIAN VEGETABIF IVARROW-An English variety for summer and fall use. Produces large oblong fruit, dark green at first, but becomes marbled with yellow as it matures Grows about 9 inches long; the flesh is white and the shell pale yellow. Pkt, 5c; 1 oz., 20c; 2 ozs., 30c: $1 / 4$ lb., 50c; 1 lb., $\$ 1.50$, postpaid.

YRT.TW SUMMMFR CROOKNFCK-A standard, early and productive summer sort; skin bright yellow, much warted; fruit about 1 foot long. Pkt., $5 \mathrm{c} ; 1 \mathrm{oz} ., 15 \mathrm{c}$; 2 ozs., 25c; $1 / 4$ lb., 40c; 1 lb., $\$ 1.25 ; 5$ lbs., $\$ 5.50$, postpaid GOTDEN CUSTARD-This is a flattened, scalloped bush clesh is pale yellow and of very fine flavor. Except for color, this squash is identical with the Mammoth White Bush. This is a splendid yellow variety to plant. Pkt., 5c; 1 oz., $15 \mathrm{c} ; 2$ ozs., $25 \mathrm{c} ; 1 / 1 \mathrm{lb}$. $40 \mathrm{c} ; 1$ lb., $\$ 1.25$, postpaid.

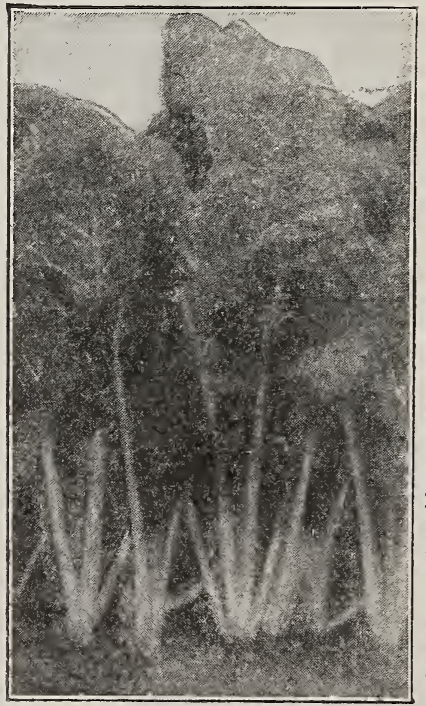

SALSIFY OR VEGETABLE OYSTER

One ounce to 100 feet row; 8 pounds to acre.

Requires a long season and a deep, rich soil. Sow in rows $2 \frac{1}{2}$ feet apart and thin to 6 inches between plants in row. Cover seed three-fourths inch. Salsify is hardy and will stand severe freezing without in jury. Prepared and han dled the same as parsnip.

MAMIMOTH SANDWICE ISTAND-This variety is large and strong, growing with long, smooth, white tapering roots and is less liable to branch than other sorts. Fine for the home garden. Pkt., 5c; 1 oz., $20 \mathrm{c} ; 2$ ozs., $35 \mathrm{c} ; 1 / 4 \mathrm{lb}$. $65 \mathrm{c} ; 1$ lb., $\$ 2.25$, post-

Swiss Chard or Spinach Beet paid.

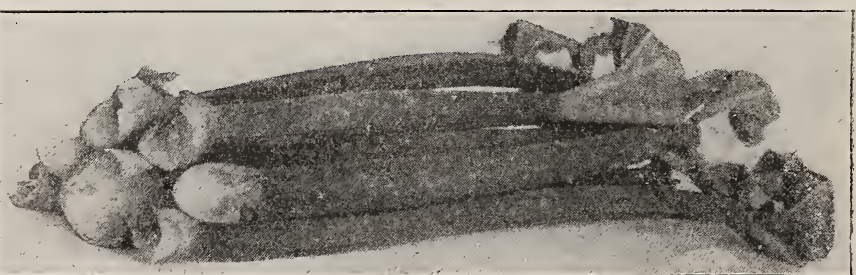

Rhubarb 


\section{TOMATOES}

One ounce for about 2,000 plants.

Sow inside in boxes or in hotbeds where the temperature is about 65 degrees. Transplant when 3 in. high to $3 \times 3$ in. each way. Transplanting will make an abundance of fibrous roots and also stocky plants. Plant outdoors when all danger frost is past in rows 4 feet apart and 3 feet apart in row. Sunny exposure and fairly rich soil is best. Trim off part of foliage to expose tomatoes to the sun.

GUIF STATE IMARKTT-Gulf State Market is earlier than any other purple tomato; the vines are exceptionally robust. This makes it less susceptible to blight than other varieties, with the probability of a perfect stand and perfect yield when weather conditions are favorable. Our tests this past season were very satisfactory in this respect. How.

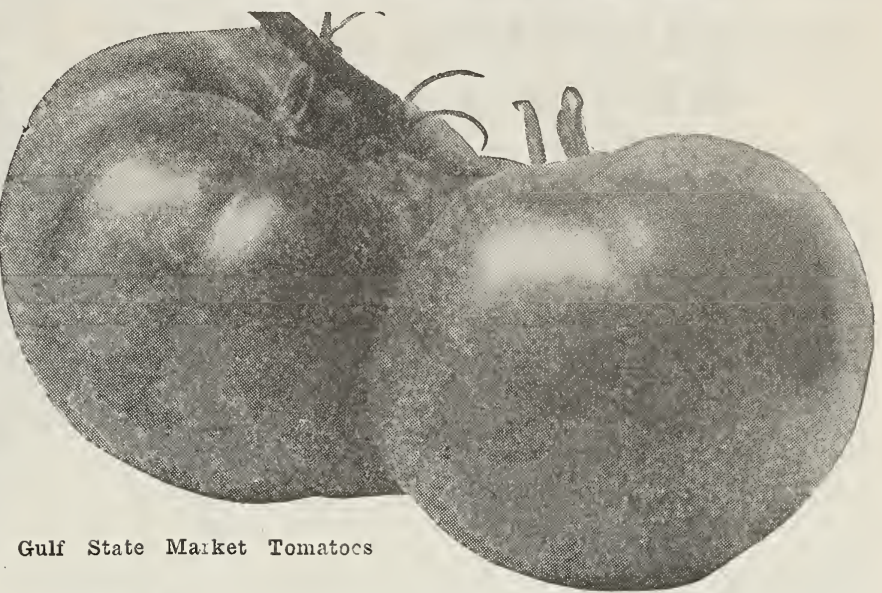
ever, in some sections, in extreme drouth it showed a little wilt, but in our opinion, Gulf State Market is about 75 per cent wilt resistant. It grows low and close together, permitting the tops to be trimmed to advantage. fruit is almost true globe shape, entirely free from cracks, blemishes about the blossom end; fruit on the same cluster ripens uniformly, making it an economical variety to pick. Pkt., $10 \mathrm{c} ; 1 / 2$ oz., $25 \mathrm{c} ; 1$ oz., $45 \mathrm{c} ; 2$ ozs., $80 \mathrm{c} ; 1 / \frac{1}{\mathrm{t}} \mathrm{lb} ., \$ 1.50 ; 1 \mathrm{lb} ., \$ 5.00$, postpaid.

IIVINGSION'S GIOBI (Pink) -A variety of al. most perfect shape. Medium size and purplish-pink color. Used very largely for greenhouse planting; also grown extensively in the South for shipping to Northern markets. It is early, productive, of very fine fiavor. and firm and solid. Pkt., 5c; oz., 35c; 2 ozs., $60 \mathrm{c} ; 1 / 4$ lb., $\$ 1.25 ; 1$ lb., $\$ 4.00$, postpaid.

JUNE FINK-In habit of growth, productiveness and size of fruit, identical with Earliana, differing only in having purple fruit; the best extra early purple or pink fruited variety. Pkt., $5 \mathrm{c} ; 1$ oz., $35 \mathrm{c} ; 2$ ozs., $65 \mathrm{c} ; 1 / 1$ lb., $\$ 1.25 ; 1$ lb., $\$ 4.00$, postpaid.

EARIIANA (Bright Scarlet)-The earliest and test of the very early tomatoes; very productive for an early sort; fruits are of fair size, round, very smooth and solid, and produced in clusters in center of the plant; color bright scarlet. Pkt., $5 \mathrm{c} ; 1$ oz., $25 \mathrm{c} ; 2$ ozs., $45 \mathrm{c}$; $1 / 4$ lb., $85 \mathrm{c} ; 1$ lb., $\$ 2.75$, postpaid.

MATCIIESS (Red)-A main crop sort of superior merit. The fruits are very large, smooth and symmetrical, ripening well to the stem. The flesh is rich. bright red in color, and of fine quality. Pkt., $5 \mathrm{c} ; 1$ oz., 30c; 2 ozs., 50c; 1/ 1b., 90c; 1 lb., $\$ 3.00$.

FARIY DETROIT (Purple)-This splendid variety is the largest and best of the early purplish pink tomatoes. The fruits are very smooth, uniform in size nearly globe shaped,

firm and of excellent quality. Early Detroit is most valuable as a shipping variety, as well as for home or market use. Pkt., $5 \mathrm{c} ; 1$ oz., $40 \mathrm{c} ; 2$ ozs., $60 \mathrm{c}$; 1/4 lb., 90c; 1 lb., $\$ 3.00$, postpaid.

\section{JOF $\mathbf{B} \mathbf{A} \mathbf{A}$} (Red) - This variety produces largest fruit of the extra early sorts. Fruits are large, ne a rly

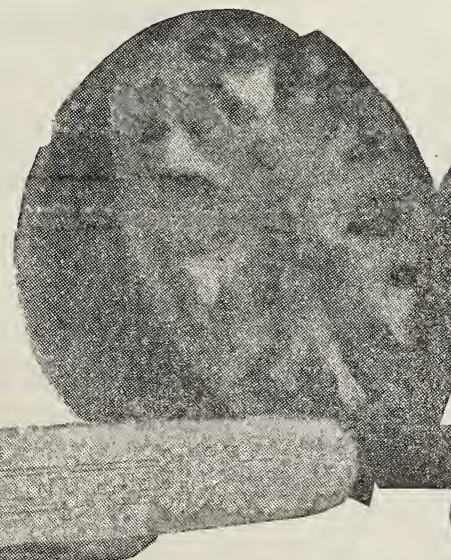

round, smooth, firm, of excellent quality; color bright red. Pkt., 5c; 1 oz., $35 \mathrm{c} ; 2$ ozs., 60c; 16 lb., $\$ 1.25$; 1 lb., $\$ 3.75$, postpaid.

ACMD (Pink) - A well known, harly, early and pro ductive sort; fruit of fair size, round and smooth; color purplish pink. Acme is solid and of excellent flavor. Pkt., 5c; 1 oz., 25c; 2 ozs., $40 \mathrm{c} ; 1 / 1$ lb., $75 \mathrm{c} ; 1$ lb. $\$ 2.50$, postpaid

PONDRROSA (Purple)-An exceptionally large, purple-fruited tomato, and for the home use of the best; fruits very solid, with few seeds. We have a very much improved stock of this variety which lacks con. siderable of the roughness and tendency to split which it formerly possessed. Pkt., 5c; 1 oz., 40c; 2 ozs., $75 \mathrm{c} ; 1 / 4$ lb., $\$ 1.25 ; 1$ lb., $\$ 4.50$, postpaid.

NEW STONg (Deep Red) -The standard and general favorite with truckers and canners; always dependable, very vigorous and productive; fruits round, large, solid, smooth and deep red in color. The most popular of the late or main crop sorts. Pkt., 5c; 1 oz., 25c ; 2 ozs., $40 \mathrm{c} ; 1 / 1$ lb., $75 \mathrm{c} ; 1$ lb., $\$ 2.50$, postpaid.

NORTON (Wilt-Resistant) - This variety was selected from the famous Stone, producing a heavy yield of large, smooth, solid, red fruit which ripens medium early. It is somewhat larger than the Stone, and is highly recommended because of its wilt-resistant features. The havoc wrought by wilt in tomatoes is serious, and if you have been disappointed in growing tomatoes because of this disease, you will be interested in this hardy, wilt-resistant sort. Pkt., $10 \mathrm{c} ; 0 \mathrm{z}, 50 \mathrm{c} ; 1 / 4 \mathrm{lb}$. $\$ 1.50$; lb., $\$ 5.50$, postpaid.

REDEIFID BFAUTY-The fruits grown in clusters of three to five and are as regular in shape and size as it is possible to produce. The color is its leading attribute, being a glossy red. Skin tough, flesh solid Plkt., 10c; oz., 25e; 1/4 lb., 90c; lb., \$3.00.

DWARE STONE (Deep Scarlet)-Pkt., 10c; 1 oz. $40 \mathrm{c} ; 2$ ozs., $75 \mathrm{c} ; 1 / 4$ lb., $\$ 1.25$, postpaid.

D W A R PON.

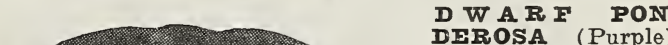
-Pkt, $10 \mathrm{c} ; 1$ oz Pkt., 10c; 1 0z.; lb., $\$ 1.50$, postpaid. YIIIOW PEAR -Pkt. 10c: 1 oz 50c, postpaid.

RED PEAR-Pkt. $10 \mathrm{c} ; 1$ oz., $50 \mathrm{c}$, post paid.

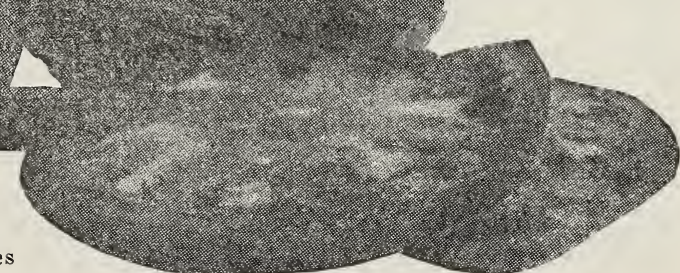




\section{TURNIPS and RUTABAGAS}

One ounce will sow 200 feet of drill; 2 pounds for an acre.

For early use, sow seed of flat varieties in open ground in spring, in drills 1 foot or more apart, using seed sparingly. Thin to 3 or 4 inches apart. For sucsparingly. Thin to 3 or 4 inches apart. For sucfall and winter sow in August and September. A good crop may often be grown by scattering seed thinly in the cornfield at the last cultivation.

\section{AMERICAN RED TOP WHITE GIOBF-A} large globular variety, very even in shape and of handsome appearance. The crown is purplish red and the remaining portion clear white. The flesh is white, of excellent quality and desirable for table use. The variety is a good keeper and a fine market sort. Pkt., $5 \mathrm{c} ; 1$ oz., 10c; 2 ozs., $15 \mathrm{c} ; 1 / 4$ lb., 25c; 1 lb., $75 \mathrm{c} ; 5$ lbs., \$3.50, postpaid.

\section{MAMMOTH PURPIE TOP WHITE GIOBE}

- The popular variety for general planting. One of the handsomest and most saleable turnips. For home or market it is unsur. passed. It is a large, rapid growing sort, being ready for the table or market in about 65 days, with globular shaped roots. Flesh pure white, and the best flavored of all turnips, raw or cooked. The skin is white, with a purple top. The most desirable sort. Pkt., 5c; oz., 10c; 2 ozs., 15c; 1/4 lb., 25c 1 lb., $65 \mathrm{c} ; 5$ lbs., $\$ 2.60$, postpaid

RED or PURPIE TOP STRAPIFAFFlat, white, with purple top. Fine grained and tender. Used for early market and table. Pkt., 5c; oz., 10c; 2 ozs., 15c; 1/1 lb., 25s; 1 lb., $65 \mathrm{c} ; 5$ lbs., $\$ 2.60$, postpaid.

\section{FXTRA FARIY PURPIE TOP MIIAN} -A white variety, purple top and strapleaf. This, with the White Milan, is the earliest of all turnips. Pkt., $5 \mathrm{c} ;$ oz., 15c; 2 ozs., 25 c; $1 / 4$ lb., 40 c; 1 lb., $\$ 1.25 ; 5$ lbs., $\$ 5.00$, postpaid.

IARGP WHITE GIOBS-Of perfect globe shape; skin white and smooth; leaves large and dark green. One of the best varieties of turnip on the market today. Pkt. $5 \mathrm{c} ; 1$ oz., 10c; 2 ozs., 15c; $1 / 4$ lb., $25 \mathrm{c}$ 1 lb., 60c; 5 lbs. $\$ 2.60$, postpaid.
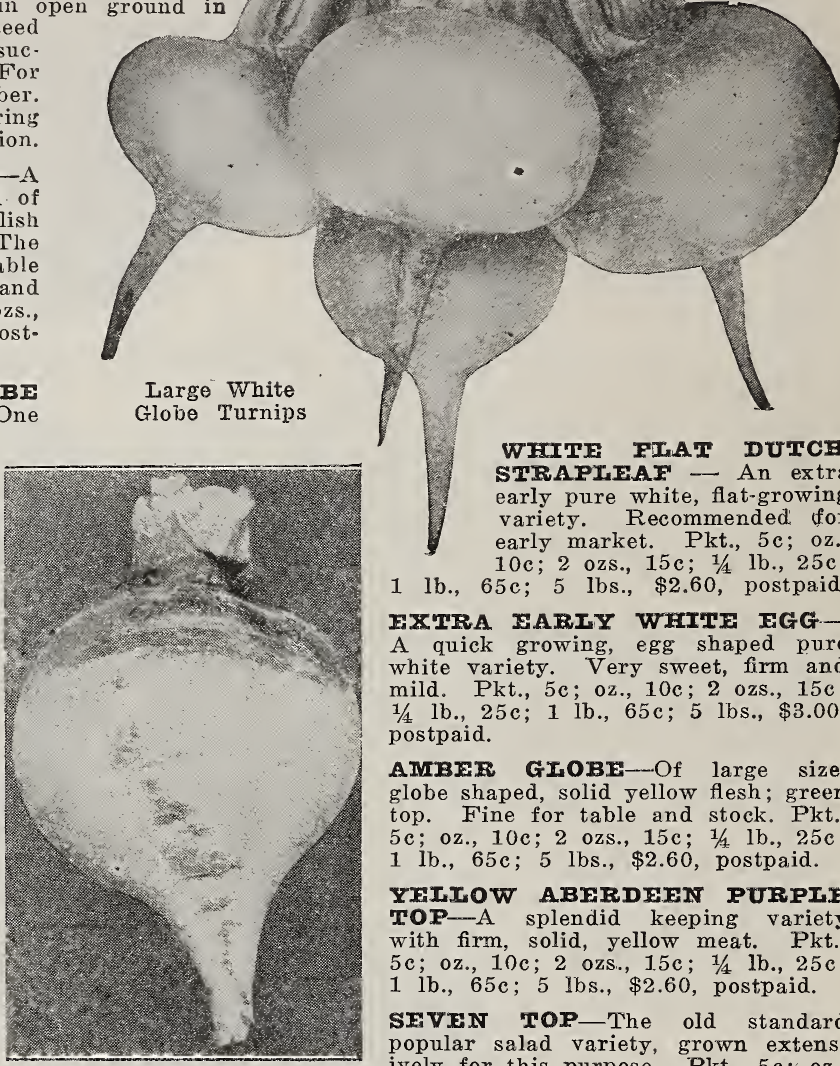

WHITE PLAT DUTCE STRAPIFAF — An extra early pure white, flat-growing variety. Recommended for early market. Pkt., $5 \mathrm{c}$; oz., $10 \mathrm{c} ; 2$ ozs., 15c; 1/4 lb., 25c: 1 lb., 65c; 5 lbs., $\$ 2.60$, postpaid. FXTRA BAIRIY WHITI EGGA quick growing, egg shaped pure white variety. Very sweet, firm and mild. Pkt., 5c; 0z., 10c; 2 ozs., 15c; $1 / 4$ lb., 25c; 1 lb., $65 \mathrm{c} ; 5$ lbs., $\$ 3.00$, postpaid.

AMBIR GIOBF-Of large size, globe shaped, solid yellow flesh; green top. Fine for table and stock. Pkt., $5 \mathrm{c} ;$ oz., 10c; 2 ozs., 15c; 1/1 lb., 25c; 1 lb., $65 \mathrm{c}$; 5 lbs., $\$ 2.60$, postpaid.

YETLOW ABERDEEN PURPIE TOP-A splendid keeping variety with firm, solid, yellow meat. Pkt., $5 \mathrm{c} ;$ oz., 10c; 2 ozs., $15 \mathrm{c} ; 1 / 4$ 1b., $25 \mathrm{c}$; 1 lb., 65c; 5 lbs., $\$ 2.60$, postpaid.

SEVHN TOP-The old standard popular salad variety, grown extensively for this purpose. Pkt., 5c: oz., $10 \mathrm{c}$; 2 ozs., 15c; $1 / 4$ lb., $25 \mathrm{c} ; 1$ lb.,

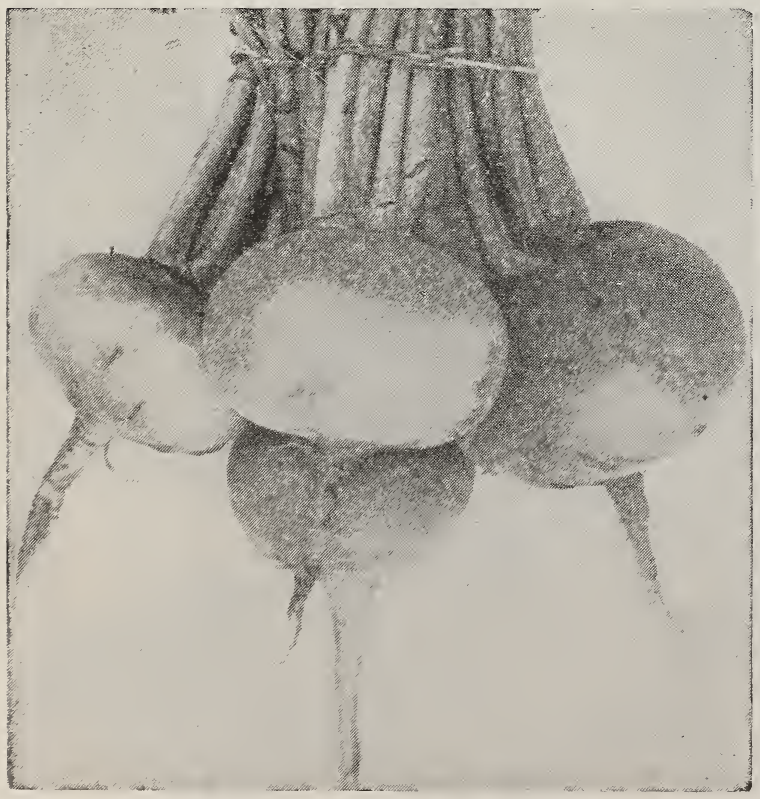
$75 \mathrm{c} ; 5$ lbs., $\$ 3.50$, postpaid.

IONG WHITE COWHORN-Roots are often 12 to 15 inches long and 3 inches in diameter, round, carrot-like in form and slightly crooked; clear white in color except a shade of green at the top; quality good. Pkt., 5c; 1 oz., 10c; 2 ozs., $15 \mathrm{c} ; 1 / 4$ lb., $25 \mathrm{c}$; 1 lb., $75 \mathrm{c} ; 5$ lbs., $\$ 3.25$, postpaid.

\section{RUTABAGAS}

Sow in drills or broadcast in June, July and August.

IIMPROVED PURPIE TOP IUUTABAGA-An improved strain of the finest yellow-fleshed rutabaga grown. Hardy, sweet and a good keeper. Pkt., 5c; oz., 10c; 2 ozs., 15c; $1 / 4$ 1b., 25c; 1 lb., $75 \mathrm{c} ; 5$ lbs., $\$ 3.25$, postpaid.

WHITE SWEDE or RUSSIAN-Roots very large, nearly globe-shaped, with a small neck; color white with a green shade at the neck; flesh white, firm and sweet. Pkt., 5c; 1 oz., 10c; 2 oz., 15c; $1 / 1 \mathrm{lb}$., $25 \mathrm{c} ; 1$ lb., $75 \mathrm{c} ; 5$ lbs., $\$ 3.50$, postpaid.

\section{TOBACCO}

The seeds are sown in the spring. When these plants are almost 6 inches high, set out, 2 feet apart, in drills, with rows 3 feet apart. One ounce of seed will make enough plants to set out three acres.

FAVANA-Grown largely for wrappers of cigars. Pkt., $10 \mathrm{c}$; oz., $50 \mathrm{c}$, postpaid

CONNECTICUT SEDD IFAF-An early variety for smoking and chewing. Pkt., 10c; oz., 50c, postpaid. IMPROVID WHITE BURIEY-Fine for both chewing and smoking. Pkt., 10c; oz., 50c, postpaid. 


\section{OUR SUPERB SPENCER SWEET PEAS}

Sow in January, February, March or April. Cover seed 2 to 4 inches, according to depth of your trench. The soil for Sweet Peas should be rich and deep, with plenty of well rotted manure in it. Wizard Brand Sheep Manure is especially fine. Heavy soils must be well worked and fertilized some time before sowing the seed. On high and dry' soils they may be sown in drills from 4 to 6 inches deep, covered with an inch or two of soil pressed firmly, and the furrow filled in as the plants grow. When the seed is well above the ground, the little plants should be thinned out so as to be at least from 2 to 4 inches apart. It is a mistake to sow too thick, but it is well to allow for seeds which may rot in the ground or be destroyed by cutworms. In low, damp soils the seed should only be planted an inch and a half or two inches deep, or they will rot during the process of germinating.

Price, any of the following varieties: Pkt., 10c; oz., 30c;

$$
2 \text { ozs., 50c; } 1 / 4 \text { lb., 90c; } 1 \text { lb., } \$ 3.00 \text {, postpaid. }
$$

\section{APPLE BIOSSOM SPENCER - Bright rose standard, with wings of very light p r im ro se flushed or tinted rose-carmine. A}

Apple Blossom Spencers very large Spencer form. A free flowering sort and a very reliable bicolored sweet pea of robust growth.

ASTA OHN SPENCER-Suffused lavender or tinted mauve sometimes with pinkish tinge. Spencer form, large and wavy. The best of the lavender sweet peas. BIU⿴ PICOTIE SPENCER-White, edged with violet blue.

COUNTESS SPENCFR-Bright clear pink, sometimes darker towards the edges; very large, open form, long stems. The first variety introduced of the Spencer type and still the best deep pink sweet pea.
DOBBIFS CREAM SPFNCER-This is the best of the deep cream or primrose colored peas.

KING EDWARD SPENCER-Brilliant crimson-scarlet; very large size and open form; best of the pure red or crimson Spencers.

KING WHITE SPRNCER-The form, size, vigor, waviness and purity of color give pre-eminence to its claim as the best Spencer yet introduced.

MASTERPIFCE SPENCFR-Clear lavender slightly flushed rose on standard.

OTHELIO SPFNCFR-A beautiful, deep, pure maroon of very large Spencer type. The most reliable of the maroon shades of Spencers.

ROYAI PURPIE SPENCER-The color is a rich warm purple, the younger flowers having a slightly softer zolor tone.

\section{COLLECTION OF ABOVE 10 VARIETIES, ONE PACKET EACH, 75c POSTPAID.}

\section{SUPERB EARLY FLOWERING SPENCERS}

\section{FARIY SNOW FIAKE-An early flowering white va-} riety of distinctive merit. The blossoms are large, of the best Spencer form and are borne in profusion on long stemis. The most desirable Early Flowering White Sweet Pea. Pkt., 15c; oz., 60c.

YARRAWA-One of the most desirable of the Early Flowering Spencers. Color a bright rose pink with a clear creamy base, the wings being slightly lighter in color. Flowers large, beautifully waved and many of them duplex or double. Pkt., 15c; oz., 60c.

FARIY HARMONY-This is the best Early Flowering Spencer, of clear lavender color. Pkt., 15c; oz., 60c.

\section{SWEET PEAS IN MIXTURES} SPENCER SPECIAL MIXTURE

This mixture from all the named sorts of the ruffled or Spencer varieties produces a gorgeous display of wonderful blossoms. Pkt., 5c; oz., 20c; 2 ozs., 35c; 1/1 lb., 60c; 1 lb., \$2.00, postpaid.

\section{GRANDIFLORA MIXTURE SWEET PEAS}

This mixture is composed of all of the largest flowering varieties of Grandiflora Peas. Pkt., 5c; oz., 15c; 2 ozs. $25 \mathrm{c} ; 1 / 4$ lb., $40 \mathrm{c} ; 1$ lb., $\$ 1.25$, postpaid.

\section{PERENNIAL MIXED SWEET PEAS}

Perfectly hardy, and vers handsome free-blooming climbers. They come up year after year. Pkt., 10c; oz., $75 \mathrm{c}$.

CUPID, DWARF OR BEDDING, MIXED

These form a line of emerald-green foliage, a little over a foot wide and 6 inches high, and from June until late summer are literally a sheet of blooms; the mixture contains all the colors. Pkt., $5 \mathrm{c}$; oz., $25 \mathrm{c} ; 2$ ozs., $45 \mathrm{c} ; 1 / 1$ lb., 75c, postpaid.

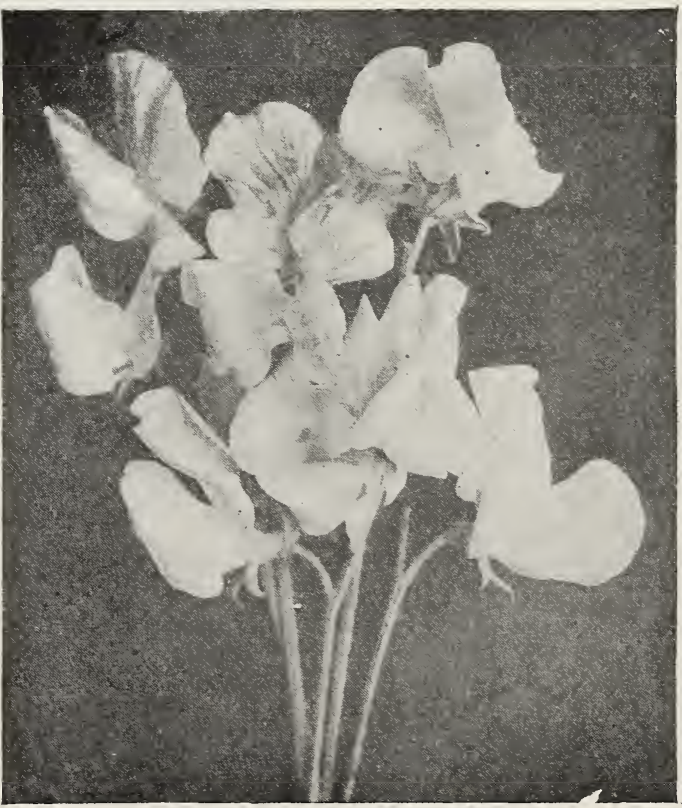

Countess Spencer Sweet Peas 


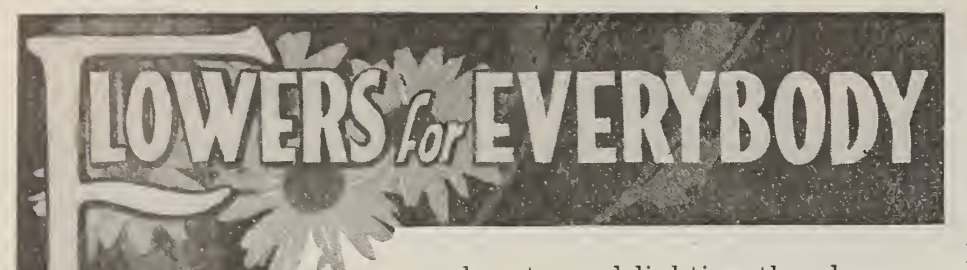

Flowers are so inexpensive, and so easy to have, that they are not generally appreciated in proportion to what they do to make a place comfortable and beautiful. Even one or two sorts near a house, the small ones in beds and the larger plants standing alone, will do wonders toward lighting the place up and making it more homelike and habitable. And a larger collection properly' grouped and arranged over a lawn or garden will make of almost any place a beautiful home and at the same time increase the commercial value of the property.

GENFRAL CULTURAL DIRECTIONS - The well-known annual flowers, such as Sweet Alyssum, Calliopsis, Calendula, Marigold, Mignonette, Nasturtiums, etc., sow where they are intended to flower, either in lines or beds, covering not over four times their size, and firming the soil over them. For those which should be started indoors, such as Heliotrope, Celosia, Lobelia, Salvia, Vinca, Verbena, etc., the best plan is to sow in boxes, covering about one-eighth of an inch and pressing firmly; cover with a pane of glass and keep in a temperature between 60 and 70 degrees. Water carefully as needed. Transplant into boxes, an inch apart each way, or put into small pots until time to plant out. They should have an abundance of air.

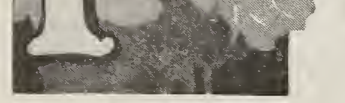

ANTIRREINUTM (Snapdragon)-Well known showy and flowers of great variety of bril. liant and handsome colors; height from 2 to 3 feet. Pkt., $10 \mathrm{c}$; oz., $\$ 1.00$.

AGERATUIM - Profuse blooming plants, bearing clusters of feathery flowers the whole sum. mer. Excellent for cut flowers and fine for large beds in summer and pot plants for winter. Height, 2 feet. Pkt., $5 \mathrm{c} ; 1 \mathrm{oz}$., $40 \mathrm{c}$.

AIMARANTHUS - Fine ornamental plant, many are grown exclusively for their handsome foliage, also have beautiful clusters of brilliant colored flowers, which are very effective for autumn decoration. Pkt., 10c; 1 oz., $75 \mathrm{c}$.

AIYSSUIM, SWEIT-One of the sweetest and most useful of summer flowers for edging, borders, rock work, etc., continuous in bloom the entire season. Flowers white, 1 foot; hardy annual. Pkt., 5c; oz., 40c. AIYSSUM, IITTIE GEMI-A sweet Alyssum with pure white blossoms, very dwarf and dense growth. It is, perhaps, the finest sort for geometrical flower beds and borders; hardy annual. Pkt., $5 \mathrm{c} ;$ oz., $50 \mathrm{c}$.

ASTER, VICTORIA-Magnificent flowers, double clear to the center; massive and showy, with regular over-lapping petals. The flowers measure 4 to 5 inches across, and the color's include many extremely delicate and some gorgeous shades. The plants are about 18 inches high. Pkt., $10 \mathrm{c} ; 1$ oz., $\$ 1.25$.

ASTERS, CRINA-Very effective in beds or borders. Mixed colors. Pkt., $5 \mathrm{c}$; oz., $75 \mathrm{c}$.

ASTER, GIANT CONET-In this class of asters the petals are very long and recurved and twisted near the center. Plants branching about two feet high, more vigorous and taller growing than the ordinary Comet; flowers larger and equal in form. Known as Ostrich Plume. Price, any of the following varieties, packet 10c; oz., \$1.50: Pure White, Light Blue, Clear Rose, Scarlet; Comet Asters, all colors mixed.

BACHEIOR'S EUTTON-It has been so perfected that fully 80 per cent of the flowers are double and semi-double; are also increased in size and present many colors and distinct markings: mixed; hardy annual. Pkt., $5 \mathrm{c}$; oz., $35 \mathrm{c}$.

BAISAM, DOUBIE IMIXED-Magnificent for outdoor planting, producing in gorgeous profusion varied color flowers; tender annual. Pkt., 5c; oz., 60c.

BAISAMI APPII VINE (Balsamina)-Curious fruits; fine climber; annual. Pkt., $5 \mathrm{c}$; oz., $30 \mathrm{c}$.

BAIIOON VINE-A free flowering vine reaching 10 to 15 feet bearing clusters of bloom and numbers of large, round miniature balloons. Pkt., 5c; oz., $30 \mathrm{c}$.
CANARY BIRD VINE- A dainty vine with beautiful cut leaves and delicate flowers of a clear yellow, somewhat resembling a canary with expanded wings. Pkt., 5c; oz., $40 \mathrm{c}$.

CAIIIOPSIS - Quick growing annuals with brilliant flowers and fern-like leaves. Sow them where they are to bloom and thin out to six inches apart. For a solid, compact border they may be planted closer. If cut occasionally they will bloom all spring. Pkt., 5c: 1 oz., 30c.

CANDYTUFT - The Candytuft is a popular flower for cutting. Seed sown in the autumn produces flowers early in the spring. Seed sown in April will produce flow. ers in June. Successive plantings may be made and thus furnish"cut flowers during the entire summer. They are easily cultivated and look best in beds or masses. Mix. ture of all varieties and colors. Pkt., $5 \mathrm{c}$; 1 oz., $30 \mathrm{c}$.

CARNATION (Marguerite) Finest double mixed. Beautiful ed and of a large size. If given a slight protection they will live through the winter and begin blossoming early in the spring. Mixed colors. Pkt., $15 \mathrm{c} ; 1$ oz., $\$ 1.50$.

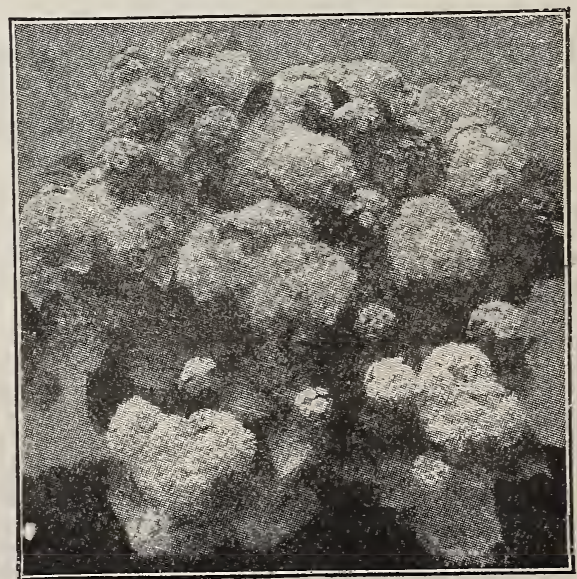

Ageratum 
COBEA SCANDENS (Cup and Saucers Vine)-A climber of rapid growth; valuable for covering trellises, arbors, trunks of trees, etc.; large, bell-shaped purple flowers; half hardy perennial. Pkt., 10c. CYPRESS VINI-A slender climber of quick growth, having small finely divided dark green foliage. It has a profusion of scarlet or white star shaped blossoms and is very desirable for ornamental trellises or wire supports. Pkt., 5c; 1 oz., $45 \mathrm{c}$.

COREOPSIS-Fine for cutting; graceful flowers; hardy perennial. Pkt., 5c; 1 oz., $40 \mathrm{c}$.

CARDINAI CIIMBER-A new and brilliant colored climber. Flowers scarlet, $1 \frac{1 / 2}{2}$ inches in diameter, the tube being $1 \frac{1}{4}$ inches in length. Vines branch freely, attaining a height of from 20 to 30 feet. Start seed indoors in March and transplant. Plkt., 10c.

Cosmos-One of the notable fall flowers. A strong, tall-growing annual, with bold flowers of exquisite daintiness and airiness heightened in effect by their foliage of feathery green. It is most effective when planted in broad masses, or long background borders against evergreens or fences. We offer only the choice, large-flowered strains. To make sure of flowering early, Cosmos should be started indoors and transplanted into dry, sandy, or poor soil, in sunny location Giant Crimson, pkt., 10c; oz., 50c. Giant White, pkt., $10 \mathrm{c} ;$ oz., 50c. Giant Pink, pkt. 10c; oz., 50c. Giant Mixed, pkt., $10 \mathrm{c}$; oz., 50c. Klcndyke Yelow, pkt., 10c; oz., $50 \mathrm{c}$.

CORN FIOWER-The well known hardy annual, noted for its old-fashioned flowers. Mixed, all colors, hardy annual. Pkt., 5c; $1 \mathrm{oz} ., 30 \mathrm{c}$.

COIEUS-The most popular of all foliage plants. Easily grown from seed, but must be started in a box in the house or hotbed, as the seed is very fine and when sown is scarcely covered, yet must be kept moist. Tender perennial. Mixed colors. Pkt., $20 \mathrm{c}$.

CANNA, MIZED-Flowers of large size and brilliant colors. Our mixture contains all the tall varieties and all colors. Pkt., 5c; $0 \mathrm{z} ., 40 \mathrm{c}$.

COCKSCOMB, CII OFIA-The finest type of the feathered cocks. comb. Huge plumes of crimson flowers. Pkt., 10c; oz., $60 \mathrm{c}$.

DAHIIAS-It is not generally realized that most beautiful Dahlias may be grown and flowered in late summer and autumn from spring sown seed. Many of them, different fro many of the named varieties on the market, and some from seed are equally beautiful the production of novel forms and combinations of colorings being most interesting.

- Single Giant Perfection - This variety produces flowers of immense size of the most bewildering variety of colors Pkt., 5c; oz. $75 \mathrm{c}$.

-Double Flowering-Double show

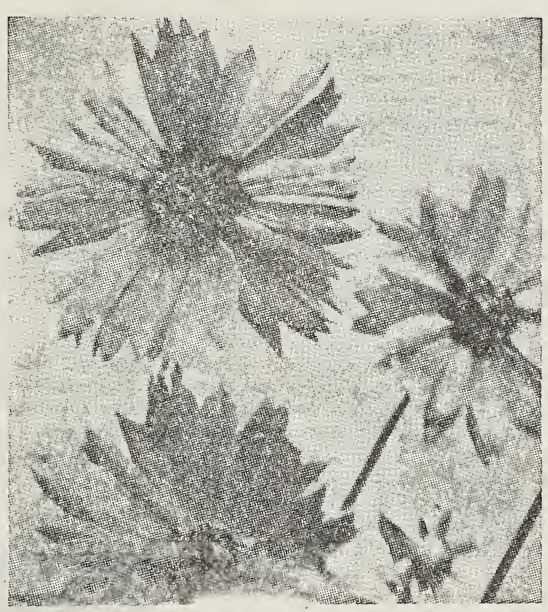

Coreopsis

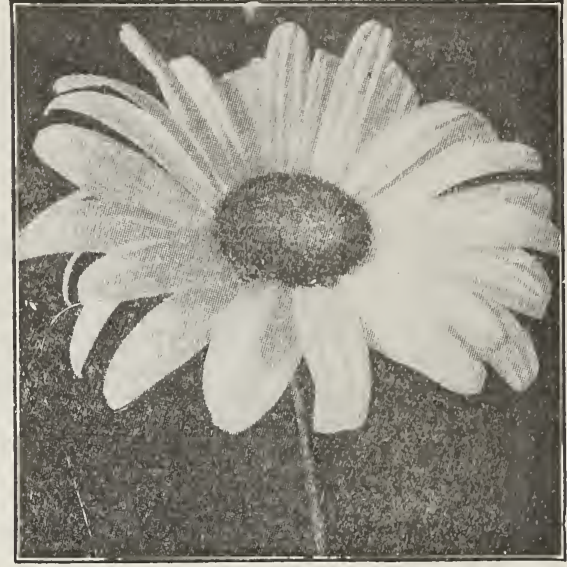

Shasta Daisy

DAISY, SHASTA-Hardy perennial, producing flower's of a pure white, often measuring 5 inches across. Long stemmed. Excellent as a cut flower. They make a showy hedge as they are covered with flowers from early fall until hard frost. Pkt., $10 \mathrm{c}$. $1 / 4$ oz., 50c.

DAISY, DOUBII-A favorite perennial plant, which will stand the winter if given the protection of a few leaves or litter; in bloom from early spring until well on in the summer. Easily raised from seed; usually sown in August, but can be sown in spring. Pkt., $10 \mathrm{c}$; $\mathrm{oz}, \$ 1.50$.

PSCHSCHTOTZIA (California Poppy)-Brilliant flowers in the shades of crimson, pink, and or. ange scarlet. The plants are about a foot high. Has finely cut leaves of a grayish green color. Blos soms from July until frost. As they are not easily transplanted, sow rather thickly. Pkt., $5 \mathrm{c} ; \mathrm{oz}$, $40 \mathrm{c}$

FORGET-ME-NOT-A pretty lit tle old-fashioned perennial, producing its flowers in early summer. Quite hardy once it is established. Pkt., 10c; oz., 75c

and fancy sorts. Pkt., 10c; oz., \$1.50.

-Double Cactus Flowered Mixed-Many colors,

twisted and curled petals. Pkt., 20c; oz, $\$ 3.00$.

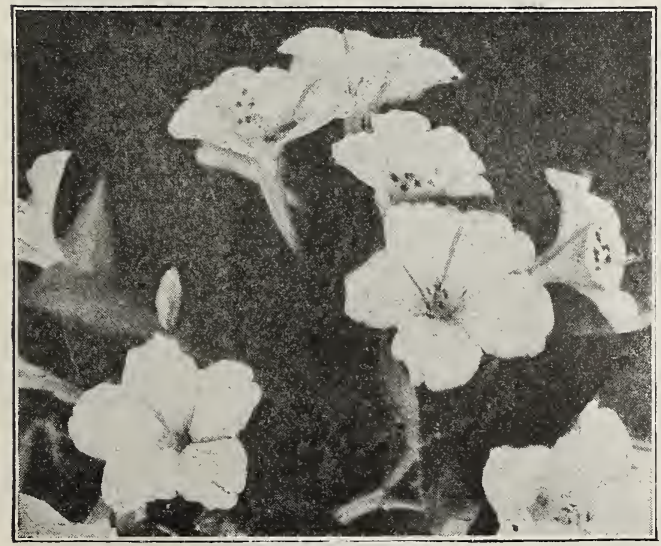

Four O vlock
FOUR O'CIOCK (Marvel of Peru) - A handsome, free flowering plant. They open their blossoms about 4 ' clock in the afternoon, hence their name. Hardy annuals; mixed varieties, Pkt., 5c; oz., 20c.

FOXGIrOVF (Digitalis)-Grows to the height of 3 or 4 feet, with dense spikes of brilliantly colored flowers which are terminal and half as long as height of plant. Colors, white, lavender and rose. A valuable flower in every perennial garden; does not usually blossom until the second year. Mixed colors. Pkt., 10c; $1 \mathrm{oz}, 45 \mathrm{c}$.

GOURDS-A tribe of climbers with curiously shaped and colored fruit. Being of rapid growth they are fine to cover old fences, trellises, stumps, etc. Tender annual; 10 to 20 feet high. Pkt., 5c. Dipper Gourd, pkt., 5c. Dish Rag or Luffa, pkt., 5c. Calabash Pipe Gourd pkt., 5c. Nest Egg Gouard, pkt., 5c. Gourds, small, ornamental sorts, mixed. pkt., $5 \mathrm{c}$.

GAITIARDTA (Blanket Flower)-They grow about $1 \frac{1}{2}$ feet tall and from early spring until late fall produce a continuous profusion of brilliantly colored flowers, red and yellow. Pkt., 10c; oz., 50c.

GOIMPFIRNA (Globe Amaranth)-Hardy annual; 2 feet. Red clover-shaped flowers. Cut them in full bloom and dried, they retain their color. Mixed. Pkt., 5c; oz., 40c.

HFIIOTROPF-Flowering during the whole season, and its delightful perfume makes it a most desirable bouquet flower. Pkt., 15c; $1 / 4$ oz., 60 e. 


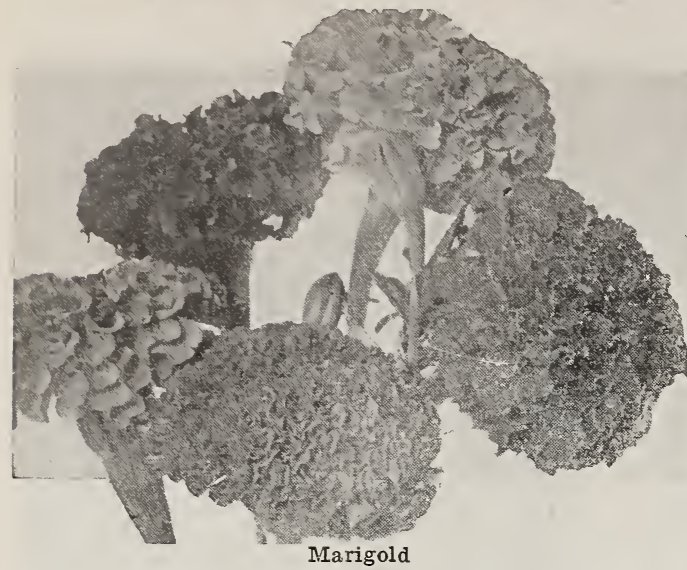

HEICARYSUM (Straw Flower)-Of all everlastings the straw flower is the best known. The plants grow 2 to 3 feet high and are covered with large flowers of white, pink, yellow or scarlet. Flowers intended for drying should be gathered when partially unfolded and suspended with their heads downward in a cool place. Pkt., 10c; oz., 50c.

HOIIXHOCK (Superb Double)-This king of flow ers growing from six to eight feet tall, cannot be exlided from the old-fashioned garden. It forms a splen did background for other hardy perennials and shrubbery. Seeds sown in the spring will produce blossoming plants the next summer.

-Hollyhock, Double Mixed-Pkt., 10c; oz., $\$ 1.50$.

- Hollyhock, Double White-Pkt., 10c; oz. $\$ 2.00$

-Hollyhock, Double Red-Pkt., 10c; oz., \$2.00.

IUMUIUS JAPONICUS (Japanese Hop)-Ornamental and rapid climber. The foliage is lovely green; splendid for covering verandas, trellises, etc. Tender annual. Pkt., 5c; oz., 50c.

IIYACINTI BEAN-A rapid growing annual, flowers freely in erect racemes, followed by ornamental seed pods. Sweet scented. Pkt., 5c; oz., 20c.

ICE PIANT-A handsome and curious plant for hanging baskets, rockwork and vases. The leaves and stems appear as though covered with ice crystals. The whole plant is peculiarly brilliant in sunshine. The flower is white and pink. Pkt., 10c; oz., 50c.

KUDzU VIN⿴ (Jack and the Bean Stalk)-It is a rapid growing vine very hardy. Its foliage is very luxuriant and its rose-colored fragrant flowers are produced in large clusters. There is no climber can equal it. Pkt., 10c; oz., $40 \mathrm{c}$.

KOCEIA (Summer Cypress)-Makes a pyramidal-shaped cypresslike bush with feathery light green foliage, deepening until it becomes a lovely crimson hue about September. Excellent for hedges along garden walks. Grows 2 to 3 feet. Pkt., $10 \mathrm{c} ; 1$ oz., $45 \mathrm{c}$.

IARKSPUR-Hard annual. These Larkspurs grow about $1 \frac{1}{2}$ to 2 feet high. A great variety of bright colors; of easiest culture, doing well in any soil; all colors, mixed. Pkt., 5c; oz., $45 \mathrm{c}$.

FARDY IARKSPURS or DETPFINIUM-Few plants are so handsome in the garden as the perennial Larkspurs. There are many species in cultivation, but the most important are the tall hybrids, of which there are many varieties with a wonderful range of color. They are valuable for their great variety in height, varying from 1 to 6 feet, for their great variety in shades of color, varying from the palest lavender through every conceivable shade of blue to deen indigo. They thrive in almost any situation or soil and are easily increased, being perfectly hardy. A good, deep, rich soil will repay with larger and better flowers. Stately plants with wonderful flow. ers produced on long spikes in various shades of white and blue. Remove the flower before the seed pods form and they will flower later in season again. All colors. Mixed. Pkt., 15c; 1 oz., \$1.25.

MARIGOID (Tall Mixed)-Large, compact flowers in the different shades of yellow and gold. Plant grows to a good height and forms a bush about 18 inches across. Begins to blossom the latter part of the summer and continues blooming until frost. Pkt., $5 \mathrm{c} ; 0 \mathrm{z} ., 45 \mathrm{c}$. MIGNONETTE-A very popular flower for cutting. Sowings may be made in April and again in Julv which will furnish cut flowers for the entire season until frost. They may also be grown in pots for winter flowering. Choice mixed. Pkt., $5 \mathrm{c} ; 0 \mathrm{z} ., 30 \mathrm{c}$.

MORNING GLORIES, JAPANESE IMPERIAT-A revelation in the size and beauty of their flower. Pkt., 5c; oz., $25 \mathrm{c}$.

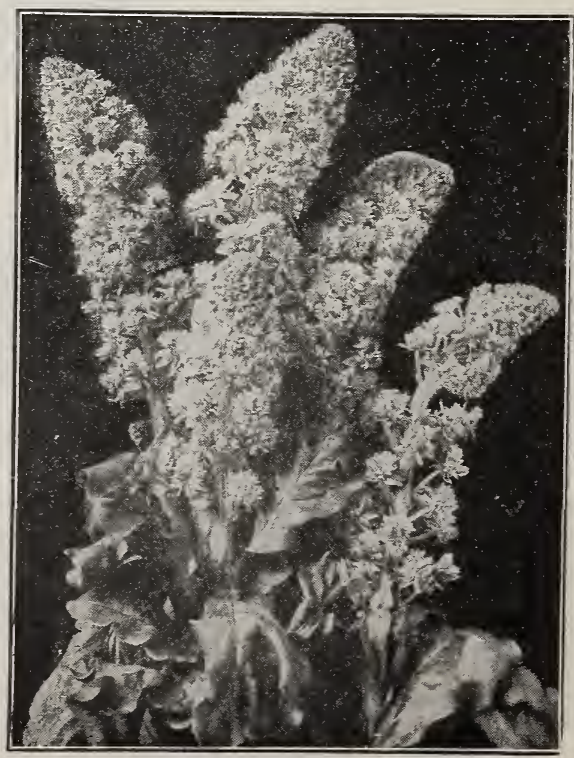

Mignonette 
PANSY-Sow seed in the fall so they will be able to make a good growth before cold weather and produce a mass of early blossoms the next year. Also sown in the spring but will not blossom as early. They thrive best in low temperature, but will do well in any location where the sun is not too hot nor the weather very dry.

-Pansy, Choice Iixed-A splendid mixture of many very fine varieties. Pkt., 10c; oz., $\$ 1.00$.

-Pansy, Extra Large Flowering Mixed-A special mix ture of all the Giant Pansies; very fine colorings; contains an almost endless variety of shades. Pkt., 10c; oz., \$1.75. -Pansy, Giant Timardeau-A beautiful class; compact growers, with enormous flowers; finest mixed. Pkt., 15c; oz., $\$ 2.50$.

PHCOX DRUMMONDI-The Phloxes are the showiest and most easily raised of all annuals. We know of noth. ing which produces such a continuous supply of the most attractive flowers in a most wonderful range of colors. All the tints of the rainbow are represented with all possible variations of stripes, veins and eyes of contrasting shades. Seed should be sown in the ground as soon as danger of frost is over and in a few weeks the beds are a blaze of glory.

-Phlox, Drummondii, Mixed-A splendid mixture of all colors; hardy annual. Pkt., $5 \mathrm{c}$; oz., $60 \mathrm{c}$.

-Phlox, Mammoth Large Flowering-The largest flowering kinds are a decided improvement on the Drummondii, producing large flowers twice the size of the latter; mixed; hardy annual. Pkt., 10c; oz., \$1.00.

-Phlox, Fireball, Scarlet-Superb when in full bloom; hardy annual. Pkt., 10c.

-Phlox, Snowball-Purest white flowers; hardy annual. Pkt., 10c.

-Phlox, Hardy Perennial-Large and showy; mixed colors; 3 feet. Fkt., 15c.

POPPIrs-Are noted for their satiny flowers of silklike texture, in many brilliant color combinations. The foliage is delicate and the blossoms are airily poised on slender stems. If the flowers are gathered early in the morning when the dew is on them, they will remain fresh in water all day. Plant the seed in succession two weeks apart for a continuous bloom all summer. Mix seed with sand before sowing so as to distribute the seed thinly and evenly.

-Poppy, Double Peony Flowered - Annual variety! mixed; large, full, double fringed flowers. Pkt., 5c oz., $20 \mathrm{c}$.

-Poppy, Shirley-These handsome flowers are single, beautiful in color, from pure white to deep crimson. Pkt., 5c; oz., $30 \mathrm{c}$.

-Poppy, Double Carnation Flowered-Extra large and double. Pkt., 5c; oz., 25c.

-Poppy, Double, Fine Mixed-A combination of all varieties, single and double flowers. Pkt., 5c; oz., 25c. -Poppy, Perennial-Hardy perennial variety, of easy culture; in bright, glowing colors. Pkt., 10c.

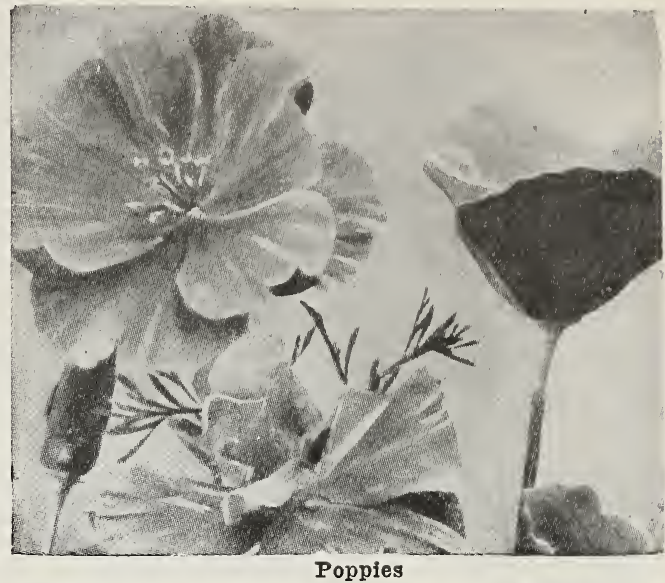

PORTUIACA (Rose Moss) - This plant will grow and bloom profusely in dry, hot situation, where almost any other plant would soon die Easily transplanted. In sowing mix the seed with dry sand to insure an even distribution. Sow in May when the ground is thoroughly warmed through, and very soon one of the loveliest of floral carpets will appear.

- Portulaca Fine Single Mixed-A great variety, mixed tender annual. Pkt., 5c; oz., $40 \mathrm{c}$.

-Portulaca, Double Mixed-A large proportion will come very double; tender annual. Pkt., 10c; oz., \$2.25.

RUDBFCKIA (Cone Flower-Bicolor Superba)-Grows about 2 feet high, forming a many-branched dense bush and producing its long-stemmed flowers in greatest abundance. Disk brown; florets yellow with brown spots at the base; 2 feet; annual. Pkt., $10 \mathrm{c} ; 1 \mathrm{oz} ., \$ 1.00$

RICINUS (Castor Oil Plant)-Rapid growing plants with palm-like foliage and showy fruits. Used with decorative effect, planted singly on the lawn or in the center of a Canna or Caladium bed. 6 to 15 feet. Mixed, all the plain and fancy sorts; tender annual. Pkt. $5 \mathrm{c} ; 1$ oz., $35 \mathrm{c}$.

SAIPIGIOSSIS-Annual, about 18 inches high, bear ing throughout the season large flowers of many beautiful colors, all exquisitely veined and laced; mixed. Pkt., 10c.

SWIET WIIIIAM (Dianthus Barbatus)-This per ennial makes a good showing in the hardy border and also splendid for cut flower purposes. Is easily grown but delights in rich soil. Plants 18 to 24 inches high. - Sweet William Single-Handsome colored flowers mixed; hardy perennial. Pkt., 5c; oz., $50 \mathrm{c}$.

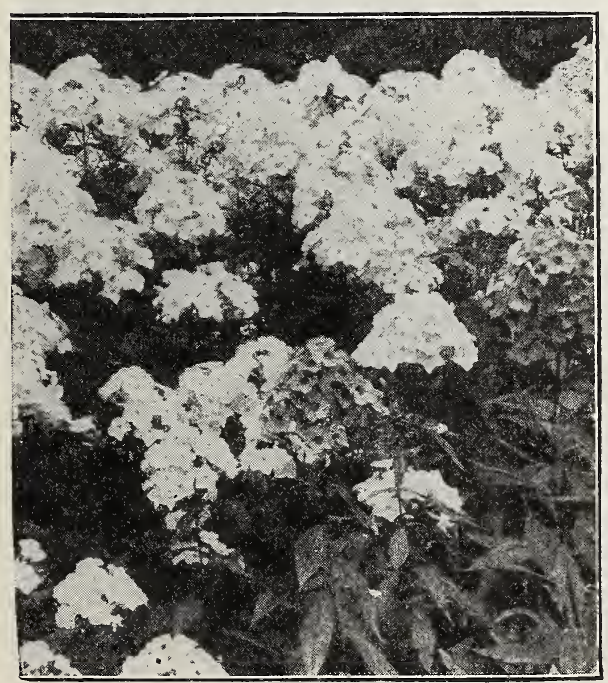

Phlox Drummondil
-Sweet William, Double-Finest double flowers; hardy per ennial. Pkt., $10 \mathrm{c} ; 1$ oz., $85 \mathrm{c}$.

SAIVIA (Searlet Sage)-The largest flowering variety of Scarlet Sage. Will reach a height of 3 to 4 feet and measure 4 feet across. To have early flowers they should be sown in March in boxes and when the young plants are well started they should be planted 3 feet apart in the flower bed. Is popular as a hedge or border plant, for brilliant color effect. Pkt., 10c 1 oz., $\$ 2.50$

SAIVIA (Clara Bedmans or Bonfire)-Flowers of a most bril liant, dazzling scarlet; one of the finest. Pkt., 15c; oz., $\$ 3.00$. SCHIZAITITUS (Finest Mixed)-A very popular border plant producing butterfly-like blooms ranging in color from pure white to the deepest crimson. They are easily grown and blossom a few weeks after sowing. They make excellent pot plants for the winter or early spring. Pkt., $10 \mathrm{c}$

SCARIRT RUNNFR-A great favorite as an ornamental climber. Bright scarlet sprays of pea-shaped blossoms. Pkt., $5 c ; 1$ oz., $20 c$.

SENSITIVE PIANT-One of the most remarkable and interesting plants in cultivation; the leaves, when touched, instantly fold up. Pkt., 10c.

SWFFT ROCKFT-Grows 2 to 3 feet high, bears spikes of showy, fragrant flowers, all colors, mixed; hardy perennial. Pkt., $5 \mathrm{c}$.

STOCKS (Gilliflower)-Stocks are hardy annuals, indispensable in every garden. There are both summer and winter bloom. ing varieties. For either bedding or pot culture they are desir-

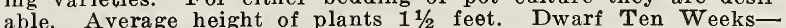
Mixed. Pkt., 10c. 


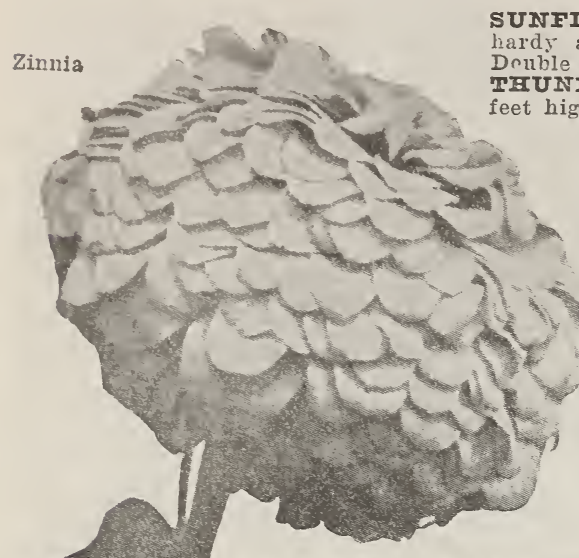

WIID CUCUMBER VINF-Ornamental climbing cucumber with curious fruit; remarkable for its luxuriance and rapidity of growth. Pkt., 5c; oz., $25 \mathrm{c}$.

NEW DAHLIA-FUOWERID ZINNIAS-In this fine new type of Zinnias the flower petals stand well apart. This characteristic adds to the texture of the flowers and lends a graceful and airy appearance. The flowers have a close resemblance to Decorative Dahlias. Many fine colors. Pkt., $15 \mathrm{c} ; 1 / 1$ oz., $50 \mathrm{c} ;$ oz., $\$ 1.50$

\section{BULBS FOR SUMMER FLOWERING}

\section{GLADIOLUS}

SCFIABFI-Clear canary-yellow, shading to soft sulphur. Largest flower stalk and leaves of all. Planted 7 to 8 inches apart in rich soil produces wonderful blooms. Dozen, $85 \mathrm{c} ; 100$ for $\$ 5.75$, postpaid. Not postpaid, doz., $75 \mathrm{c} ; 100$ for $\$ 5.50$.

CEICAGO WHITE-White, lavender markings in throat. Doz., $75 \mathrm{c} ; 100$ for $\$ 5.00$, postpaid. Not postpaid, doz., 65e; 100 for $\$ 4.75$.

AMERICA-Delicate lavender-pink flowers, of large size, borne on stron tems, and well placed; splendid habit; still very popular as a cut flower variety. Doz., $60 \mathrm{c} ; 100$ for $\$ 3.75$, postpaid. Not postpaid, doz., 50c; 100 for $\$ 3.50$ MRS. FRANCIS RING-Brilliant vermilion-scarlet. Most popular and effective variety for all occasions. Large size. Doz., 60c; 100 for $\$ 3.75$, postpaid. Not postpaid, doz., $50 \mathrm{c} ; 100$ for $\$ 3.50$.

BARON J. EUIOT-The leading purple variety, Doz, $\$ 1.10 ; 100$ for $\$ 6.75$, postpaid. Not postpaid, doz., $\$ 1.00 ; 100$ for $\$ 6.50$.

NIAGARA-A delicate cream shade, blending to canary-yellow, splashed with carmine. Doz., 75c; 100 for $\$ 5.00$, postpaid. Not postpaid, doz., 65c; $100, \$ 4.75$. HAIIIY-The predominating color of, these flowers is delicate salmon pink with a slight roseate tinge, though the lower petals bear a creamy blotch with a 作 Doz., 75c; 100, $\$ 5.00$, postpaid. Not postpaid, doz., $65 \mathrm{c} ; 100$ for $\$ 4.75$

MIXID GIADIOIUS CIIIDSII-Superb; large flowered; mixed colors. Per doz., 50c; per $100, \$ 3.25$, parcel post paid. By express, doz., 40c; $100, \$ 3$.

\section{CANNAS}

They do well in all sections of the country: succeeding in any kind of soil. HUNGARIA-The new pink canna with green foliage, a beautiful shade of rose pink, 4 feet. Each, 20c; doz. $\$ 2.00$, postpaid. Not prepaid, each, $15 \mathrm{c}$; doz., $\$ 1.75$

FUREA-Best white canna. large flowers; green foliage; 4 feet. Each, $25 \mathrm{c}$ : doz., $\$ 2.25$, postpaid. Not prepaid, each, 20c; doz., $\$ 2.00$.

THF PRISIDFNT - Greatest red canna. The immense flowers are of glowing orange red color with the edge and throat turning to gold. Green foliage. Each 20c; doz., $\$ 2.00$, postpaid. Not prepaid, each, $15 \mathrm{c}$; doz. \$1.75 G HUMBRT-Orange scarlet, bronze foliage, $4 \mathrm{ft}$. Each, $2 n_{c}$; doz. $\$ 2.00$, postpaid. $15 \mathrm{c}$; doz., $\$ 1.75$.

\section{PEONIES}

RED, PIN K, WHITE-Each, $50 \mathrm{c}$ postpaid. Not prepaid, each, $40 \mathrm{c}$; doz. $\$ 3.50$

\section{CHOHCE DAHLP:3S IN COLORS}

Plant bulbs in March and April, 3 feet apart. The dahlia is one of the prettiest of our summer flowers.

Double Pink, Double White, Double, Salmon, Double Purple, Double Scarlet, Double Orange, Double Yellow, Double Striped. Each, $20 \mathrm{c}$; doz., $\$ 1.75$, postpaid. Not prepaid, each, 15c; doz. $\$ 1.50$

\section{TUBEROSFS}

\section{ARIISTROITG'S EV고-BLOOMING} TUBEROSE-A single sweet-scented early blooming variety; blooms longer than the double. Doz., 60c; 100 for $\$ 4.00$, postpaid. Not prepaid, doz., $50 \mathrm{c}$ 100 for $\$ 3.75$.

NOUBIE PFARI-Doz., 70c, postpaid. $\$ 4.00$.

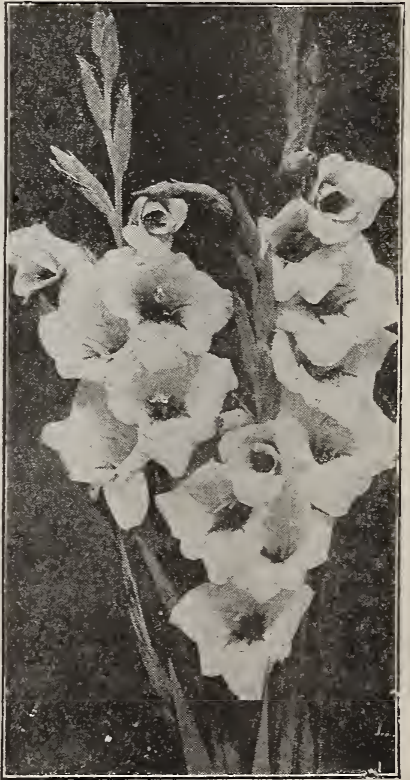

Gladiolus

\section{CALADIUMS} or for planting out upon the lawn cess, each, $10 \mathrm{c} ;$ doz., $\$ 1.00$ each, $20 \mathrm{c} ;$ doz., $\$ 2.00$

ch, 50c; dozen, $\$ 4.25$, postpaid 


\section{SELECTED SEED CORN}

TAIT'S FARIY WHITE DENT (90 days)-The stalk is short and inlck. 'lise ears grow long on the stalk, from 7 to 9 inches in length, almost parallel throughout, of medium size, averaging 14 rows of grains. The grains are pure white, compact and heavy. The cob small. Qt., 30c; 4 qts., 75c, postpaid.

IOWA SIIVER MINI (100 days)-The stalks grow to a height of 7 to 8 feet and set the ears about $3 \frac{1}{2}$ to 4 feet from the ground. The ears measure from 10 to 12 inches in length. They are very uniform in size and shape, 16 to 20 straight rows of deep, pure white kernels on a small cob. It is the heaviest yielder we know. having yielded over 100 bushels to the acre. Seventy pounds of ears will make 62 pounds of corn. It is entirely distinct and will give satisfaction. Qt., 25c; gal., 70c, rnstpaid.

MOSBY'S PROTIFIC (120 days) - The most prolific corn in existence; the stalks are tall, bearing 3 to 5 fine ears. The grains are long, set close to a small cob, very uniform in shape, well filled. It has good roots and will withstand storms better than any other prolific sort. Another important feature of this fine corn is its abundant foliage, which renders it superior to most sorts for ensilage purposes. This is a Southern corn, and is recommended for general crop. It is purely white, small cob, deep full grain, neither too hard no too soft, and stands crowding in the drill as close again as any other kind. Ears of medium size. Quart, 30c; 4 qts., 75c, postpaid.

ST. CIARIFS WFITE, FED COB (100 days)-A large medium late, tall-growing variety, producing an abundance of fodder. The ears are very large, both in length and circumference. The grains are long, broad. deep and firmly set in a medium large red cob. Qt., $25 \mathrm{c} ; 4$ qts., $70 \mathrm{c}$, postpaid.

NEAI'S PAYMASPER-This corn was originated in Williamson County, Tennessee. The grains are pure white, deep, broad and set very solid on a red cob of medium size. The stalks grow from 8 to 10 feet high. The ears are very uniform in size and shape, running from 9 to 12 inches in length, containing 16 to 20 rows, and averaging in weight from 1 pound to $1 \frac{1 / 4}{4}$ pounds. This is a highly bred corn, containing a high percentage of protein. Maturing about medium, it is well filled at both butts and tip. Every stalk bears two welldeveloped ears. Qt., $30 \mathrm{c} ; 4$ qts., $75 \mathrm{c}$, postpaid.

MEXICAN JUNE-This is a valuable addition to our large and selected list of field corn, best adapted for the South, has been thoroughly tested in the past and has proven all that was claimed for it. It is a strong, robust grower, sending the roots deep into the soil. Stands heat and drouth well. Ears large, small grain and well covered with shucks. Should be planted in succession from middle of April to end of July. Qt., $25 \mathrm{c} ; 4$ qts., $70 \mathrm{c}$, postpaid.

THNNESEE RED COB, WHITE-A large, white, red cob corn. Ears are medium size, 16 to 18 rowed; grains are very large, deep, wide and thick. Matures in 100 to 110 days. This corn makes fine meal. Qt. $30 \mathrm{c} ; 4$ qts., $75 \mathrm{c}$, postpaid.

HICKORY XING (100 days) - The cob is so sinall and the grain is so large that when an ear is broken in half

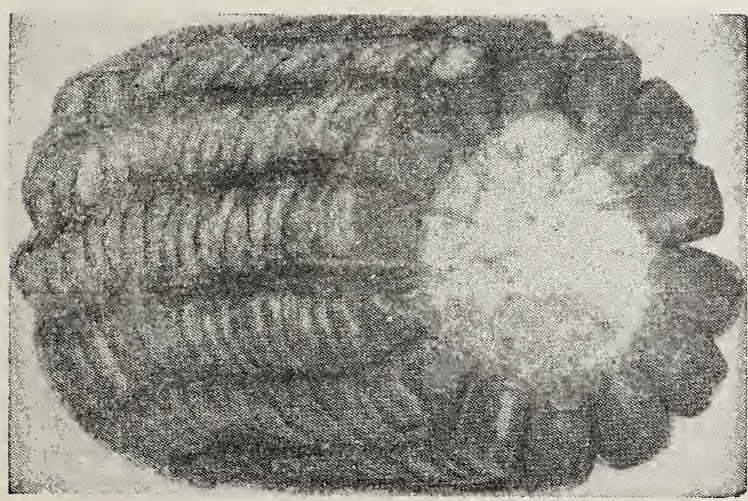

one grain will cover the entire end of the cob. Nearly all of the stalks bear two ears, and we consider it one of the best white corns grown. Does well on thin land. Qt., 25c; 4 qts., $70 \mathrm{c}$, postpaid.

CHAMPION WIITE PEARI-A highly bred, pure white 90-day corn, large ear and a heavy yielder. Ears about 12 inches long and average 1 pound in weight. Uniform in weight, size and color. Qt., 25c; 4 qts. 70c, postpaid.

\section{YELLON MARIETIES}

NINETY-DAY EARIY YIIIOW-This is a stand ard variety; matures quick and yields good crop. Is used extensively by truckers and market gardeners. Qt. $25 \mathrm{c} ; 4$ qts., $70 \mathrm{c}$, postpaid.

YEIIOW IZAIIING-A very early growing corn matures in about 90 days; always dries out quickly, therefore a desirable variety for early crop. Qt., 25c: 4 qts., $70 \mathrm{c}$, postpaid.

TENNESEE MAMMOTE YEILOW-Ears are of a perfect shape, long, and filled out to the end of the cob. The grains are not of a flinty type, neither are they so soft. A Southern grown large-eared yellow corn, sure to give satisfaction. Quart, $30 \mathrm{c} ; 4$ quarts, $75 \mathrm{c}$, postpaid.

MORTGAGL IIFTER-A large-eared variety of yel low corn. Matures medium early, about 90 days; a big yielder. The ears are well filled with bright yellow grains of fair size. Quart, 25c; 4 qts., 70c, postpaid.

REID'S 토ARIY YEIIOW DENT-This is a leading standard yellow variety, originated in Illinois many vears ago, and is a type that experts have failed to change for the better. In our opinion this is the most popular variety of yellow corn grown in the United States. We offer fine stock of this leading standard variety. which is among the best all around purpose Yellow Dent Corn grown. Color deep yellow, with lighter cap. Grain very deep, closely packed; butts and tips almost entirely covered over. The leaves and stalks of Reid's Yellow Dent make fine ensilage and fodder. Well adapted for our Southern country. Matures in 90 days. Quart, 25c; 4 quarts, 70c, postpaid.

IOWA GOID MIND-This is a very early variety. ripening in 90 days. The ears are large and the cob small; the grain is deep and a bright golden yel. low. Quart, 25c; 4 quarts, $70 \mathrm{c}$, postpaid.

FURIKA WIITE FNSIIAGF-The best known silage maker. Grows tall with an abundance of fodder and averages two good ears on good ground. If you have a silo to fill, don't try common seed on poor soil. Plant a small acreage of Eureka and make it rich. Seed for this season limited. Place your order early; can be planted in June or after

Tennessee Mammoth Yellnw oats. Quart, 30c; 4 quarts, 75c, postpaid.

SEE PAGES 49 AND 50 FOR QUANTITY PRICES ON CORN 


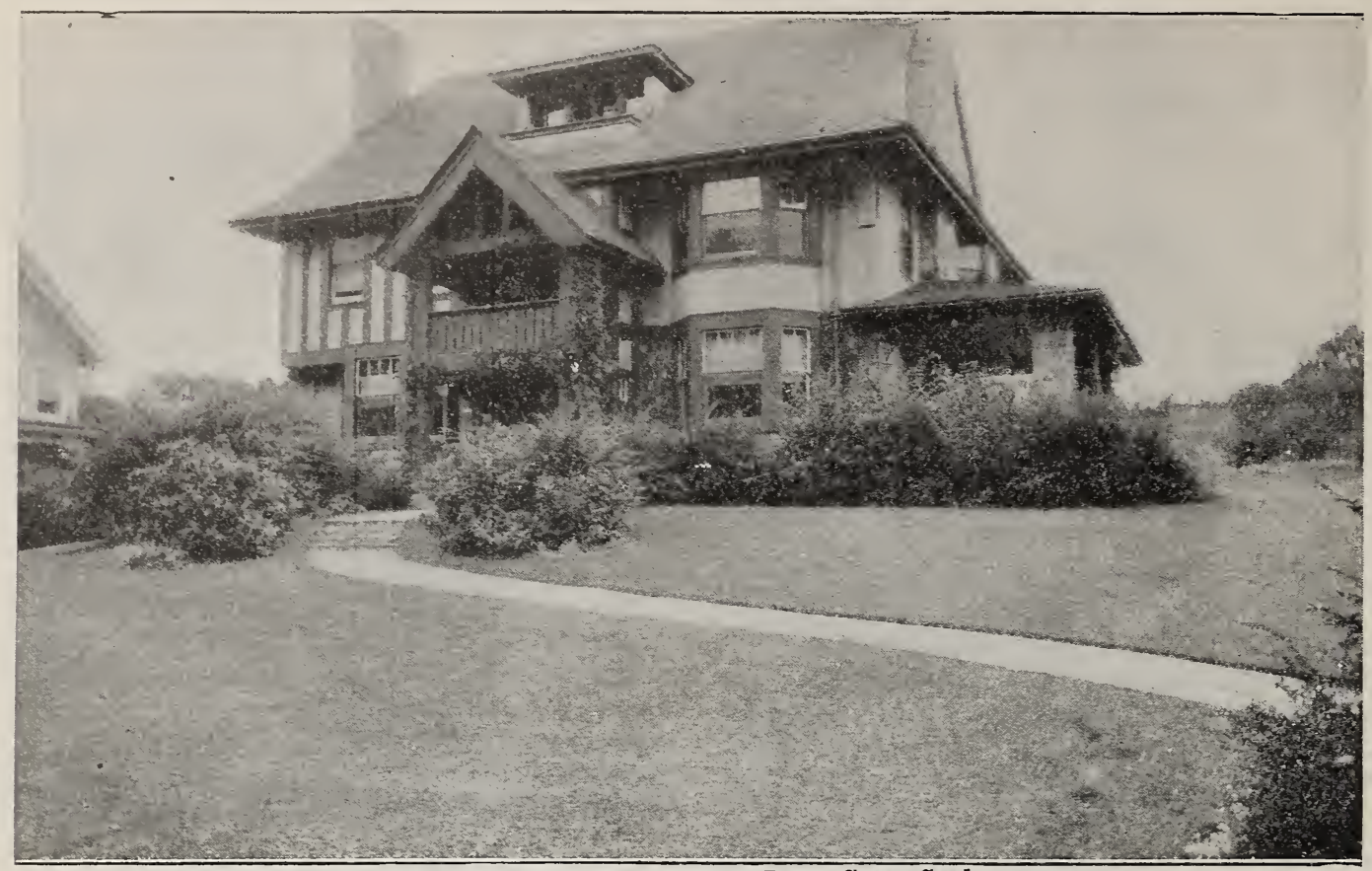

Grown from Our Sunny Sonth Jar'n Grass Seed

\section{The Best of Grasses}

For those desiring a permanent lawn we are listing below only those mixtures that are beyond question the best obtainable. With these high grade seeds you can either thicken the present lawn or plant an entirely new one. The pasture grasses are well known and do not need a lengthy introduction, being selected with great care for their vitality and thrifty growing qualities.

IAWN SBgD-It is often difficult to get a good lawn because it has been found that no one grass will give satisfactory results at all seasons and on all soils. Experiments have proven the value of combining various grasses that will produce an evergreen lawn, giving permanency and beauty of sward. Sow one pound to evers 225 square feet, on well enriched, deeply prepared seed bed. An application of bone meal three or four times a year will keep the lawn rich in color. A top dressing of sheep manure will keep the lawn healthy and vigorous.

SUNNY SOUTH IAWN GRASS-1 lb. sows 225 square feet; 40 to 50 lbs. sows 1 acre. It is composed of robust-growing grasses and is a satisfactory mixture for parks or large places where lawn and grazing are to be combined, or where special care cannot be given. This mixture will stand dry, hot weather better than the finer lawn grasses. 1 lb., $60 \mathrm{c}$; parcel post paid.

SHADY SPOT IAWN GRASS-A special mixture of grasses adapted to growing under trees and in shady places where it is difficult to get other grasses to grow. 1 lb., 60c, parcel post paid.

\section{PERMANENT PASTURE GRASS MIXTURE-} Furnishes pasture all the season from early Spring through the Winter. Sow in early Spring or Fall, using $1 \frac{1}{2}$ bushels to the acre. Lb., $35 \mathrm{c}$, parcel post paid.

PERIMANENT MEADOW GRASS MIXTURE-A special mixture for a lasting hay crop. Sow in spring or fall, using $1 \frac{1}{2}$ bushels to the acre. Lb., $35 \mathrm{c}$; parcel postpaid.

ITAIIAN RYE-Recommended principally for fall planting, but can also be sown early in the spring. A very quick growing grass. It is an annual and requires seeding each vear. It should be cut when in bloom for hay. Splendid for pasture and lawn mixtures with other grasses. Sow at the rate of two to three bushels to the acre. 1 lb., $30 \mathrm{c}$, postpaid.
KFNTUCKY BIUE GRASS-This famous grass is well known in all sections and, where the land is suitable, is one of the most profitable of all for pasture. It grows well on any stiff or loamy soils in central and northern states where rich, moist, though moderately well drained, and succeeds fairly well in some sections of the South, where lime is present in the soil, being largely used with Bermuda Grass. Kentucky Blue Grass is at its best in the spring and fall months, but being rather sensitive to heat, does not grow luxuriantly during the summer months. It takes a considerable tim $\theta$ to get a good stand of this, as it grows very slowly at the start; when once established forms a close, compact turf, making a fine pasture; also fine for lawns. 1 lb., 50c, postpaid.

CARPFT GRASS-Excellent for lawns or pasture purposes on coast and all sandy lands. Grows equally as well on uplands. It stays green all year. Stools heavily from one parent stalk and spreads rapidly. Blades are wide and give fine forage, and, when well set, forms thick, green carpet that cannot be uprooted by any amount of grazing. Sow 7 to 10 pounds to acre broadcast. 1 lb., $75 \mathrm{c}$, postpaid.

FigGISI BUUI GRASS (Meadow Fescue or Ran. dall Grass) - A splendid grass for permanent pastures, starting early and also furnishing excellent pasture very late in the season. It also makes good hay, growing on almost any soil, thriving best in that which is moist. Per lb., 45c, postpaid.

PFRMANENT HOG PASTURE GRASS MIXTURE - A combination of mixed clover and best grass suitable for hog pasture. Sow in early Spring or Fall at rate of 1 bushel to the acre. Lb., $40 \mathrm{c}$, parcel post paid.

TIMOTHY AND AISIKa MIXED-Suitable mixture for wet lands, furnishing good pasture and hay. Sow in early Spring and Fall, 15 pounds of the mixed seed per acre. Lb., $35 \mathrm{c}$, parcel post paid. 
THE BEST GRASS SEEDS-(Continued)

FNGIISF RYE-Very valuable variety for permanent pasture, also for lawn purposes. It makes a very heavy leaf growth for pasture or hay. Withstands drouth to a remarkable degree. Used extensively throughout our section for lawns. Use it in Bermuda sod to keep the lawn green during the fall, winter and early spring, when the Bermuda is dormant. Sow from September until March at the rate of two to three bushels to the acre. 1 lb., $30 \mathrm{c}$, postpaid.

JOHNSON GRASS-A most prolific perennial hay and pasture grass, eminently suitable to hot, dry climate and soils. It makes excellent hay and furnishes an enormous amount of grazing. No drouth, methods of culture or application of chemicals to eradicate it will destroy it when once sown, therefore, we do not recommend it to be sown on any land which is intended in future years for other crops. The best time for cutting is before the heads appear, as, if allowed to ripen, it becomes unfit for stock. Sow in March or April, 1 to $1 \frac{1}{2}$ bushels per acre. 1 lb. $35 \mathrm{c}$, postpaid.

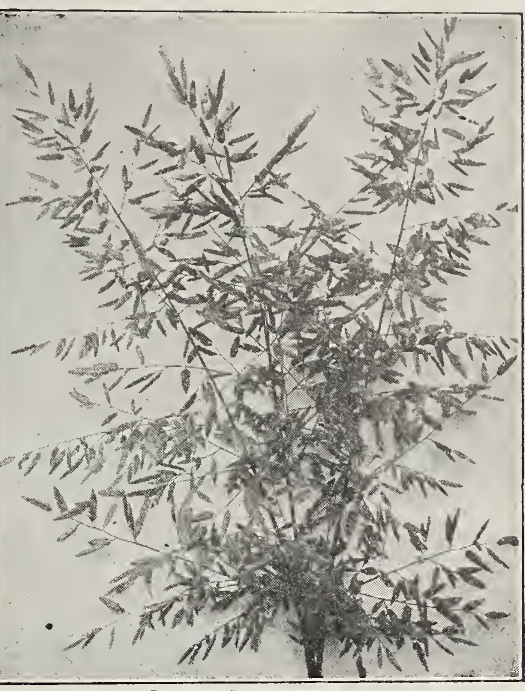

RIIODES GRASS-It is a perennial, growing from three to four feet high, with large numbers of very long, narrow and tender leaves, and with rather a few branching seed spikes or slender branching stems. It is a species that does not spread by under ground root-stalks, but produces running branches which root at the joints or nodes, thereby producing new plants. The runners are not so abundant when the grass is growing thickly, and, therefore, does not materially interfere with the machinery at the time of harvesting the hay crop. Per lb., 75c, postpaid.

PASPATUM DITATATUM or DAIIAS GRASS-Sow eight to ten pounds to the acre. Has given splendid results in the South. It is an ideal grass for dairy farmers, as it produces enormous quan. tities of fresh, green, juicy feed during the hottest weather. It also keeps green during the winter. Germinates slowly and requires from three to four weeks of warm, moist weather to sprout. Plant from November to March, 3 pounds per acre. Lb., 60c, ppd.

ORCIARD GRASS-This is one of the very best grasses for upland, loamy or moderately stiff soils, affording a large amount of pasturage as well as making excellent hay if cut when in bloom. It grows about 3 feet high and matures much earlier than Timothy, does not exhaust the soil and will produce 2 to 3 tons per acre of fine hay. Having a tendency to grow in clumps, it does better if sown thickly. $1 \frac{1 / 2}{20} 2$ bushels being the amount usually sown. It does especially well if used with other grasses. 1 lb., $30 \mathrm{c}$, postpaid.

BFRMUDA GRASS-Very popular and a great boon in the South for pasture; when once established, no amount of drouth or hot weather will kill it out. It succeeds on nearly all soils, furnishing a constant growth of grass during the Summer, but becomes brown and bare in the Fall and Winter. It cannot be recommended too highly for pasture and general culture in the South, and it is also excellent for Summer lawns. Its strong, creeping roots will absoltuely prevent wash. Per lb. $65 \mathrm{c}$, postpaid.

TAII IMEADOW OAT GRASS-A tall growing grass with fiat leaves. It has proven very hardy and may te sown either in the fall or spring. It will do well on woodland pastures where it is possible to prepare the soil thoroughly. Ready to cut for hay as soon as it blooms. A good stand can be cut two or three times a season; 30 lbs. of seed to the acre. $1 \mathrm{lb}, 45 \mathrm{c}$, postpaid. lb., $30 \mathrm{c}$, postpaid.

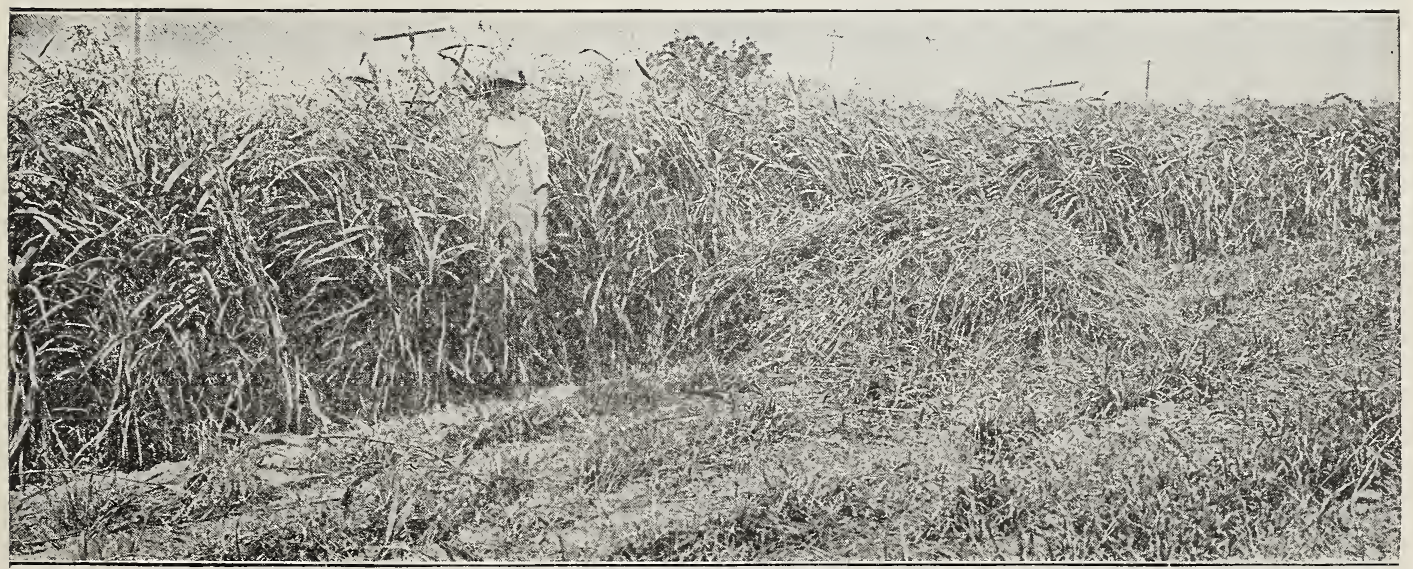

Field of Sudan Grass Ready for Cutting

TIMOTHY-No grass is better known than this, nor more generally grown, as it produces the best hay of all grasses, but is of little value for pasture. It produces good hay on almost any class of land, but in this section is best suited to bottom lands or good, well. drained soil. Yields about $1 \frac{1 / 2}{2}$ to 2 tons hay to acre. 1 lb., 20c, postpaid.

SUDAN GRASS-A forage crop of immense value. Sudan is an annual, therefore it is necessary to sow small and tender, stools wonderfully; makes fine hay and much relished by stock. Yields 2 to 4 tons per acre. Sow in April, in drills or broadcast, using 3 pounds to the acre, having drills 3 feet apart, and cultivate. If sown broadcast, 14 to 20 pounds will plant an acre. Sudan can be cut two or three times during the season. 1 lb., $25 \mathrm{c}$, postpaid.

RED TOP OR HFRDS GRASS-Succeeds better on more soils than any other grass and in all sections of the United States. Grows slowly but becomes very vigorous later and spreads rapidly into a compact sod. Suitable to stiff soils and in low situations subject to overflow, producing luxuriant growth, attaining a height of 3 to $31 \%$ feet. For the bes quility it should be cut when in bloom: ripens about the same as Timothy. 1 


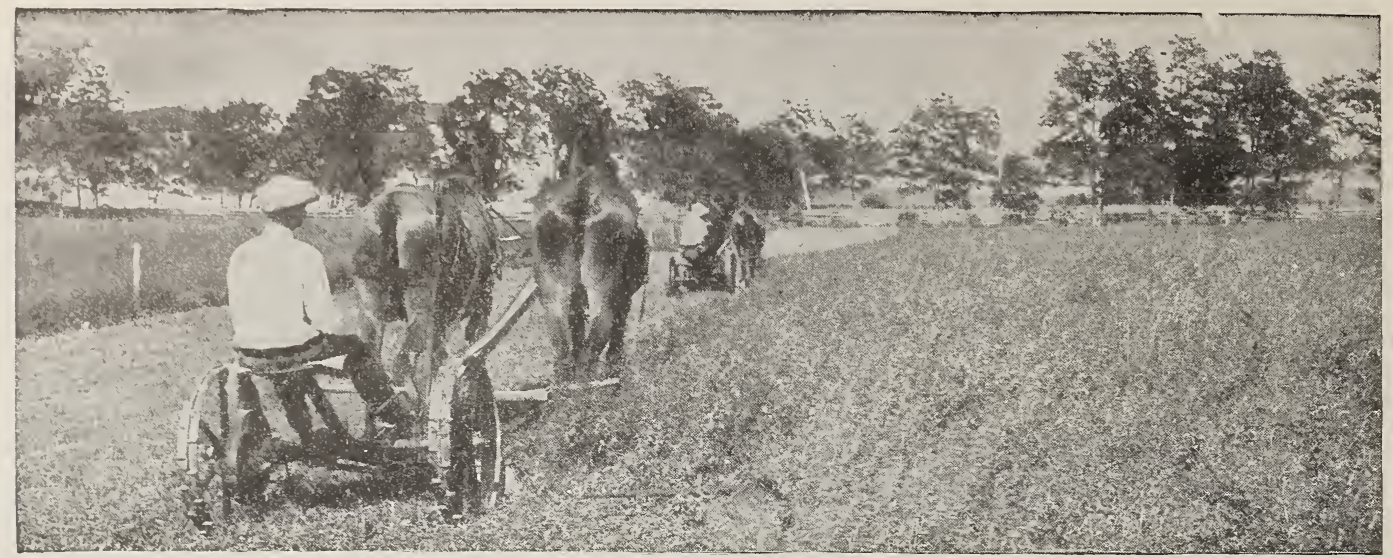

\section{High Grade Clover}

AIFATFA CIOVER This Clover is being more largely planted in the South every year. When thoroughly established can be cut three or four times a year, yielding heavily each cutting. Soil must be thoroughly prepared by deep plowing and harrowing until it is in fine condition. Sow 20 to $25 \mathrm{lbs}$. per acre. Spring seedings may be made during March and April, and in the fall during September and October on any good soil if properly drained.

FANCY IRANSAS AIFAIFA-This represents our idea of a real quality and genuine worth in Alfalfasomething to meet all requirements of our most discriminating customers. Lb., 40c, parcel post paid.

DAIOTA NO. 12 AIFATFA-This variety is the result of years of careful breeding and represents the highest type of Alfalfa. Dakota produces exceptionally hardy Alfalfa, practically immune to Winter killing. Stands drouth and heat as well. Highly recommended by Mississippi Experiment Station at Stoneville. Our seed is the genuine Dakota No. 12 stock. Lb., 50c, parcel post paid.

VER A valuable farm crop, largely used for pasturage and soil improvement. Yields two to three cuttings per year. First crop makes rich feed and is most valuable for hay. Clover draws nitroge nfrom the air largely and is one of the best soil renovating crops. Clover, intelligently used, is the farmer's best friend.

Should be used as a rotation crop. Sow in fall or spring. 10 to $12 \mathrm{lbs}$, per acre. Lb., 60c, postpaid. ILAMMOTII SAPIING CIOVIR-Very much like the common Red Clover, but larger, heavier and later. Recommended for thin soils. Sow 10 to 12 pounds to the acre. L,b., $60 \mathrm{c}$, postpaid.

JAPAN CTOVBR (Lespedeza Striata) - To obtain a good stand, disc-harrow your land, then scatter the seed on top, roll the field; this will cover them enough. Sow in March or April. Seeds weigh 25 pounds per bushel. Sow 20 to 25 pounds per acre. Grows anywhere; is tenacious in any soil. lasts always; well known in the South. It may be classed among the most valuable hay and pasture plants in the South. 1 lb., $40 \mathrm{c}$, postpaid.

AISIFE CIOVIR-Thrives well on damp soils or in situations where it is impossible to secure a catch of Red Clover. Because seed goes so much further than Red Clover, and because of its comparatively reasonable price this year, many farmers are giving Alsike the preference. It is also largely sown with Timothy. Sow 6 to 8 pounds to the acre in the spring. $1 \mathrm{lb} ., 40 \mathrm{c}$, postpaid.

INEIIOTUS or SWIEI CIOVER-A variety of clover which, when young, resembles alfalfa, but on mature development grows from 4 to 6 feet in height. It is extremely vigorous and especially adapted to waste lands, though by many prominent farmers and stock

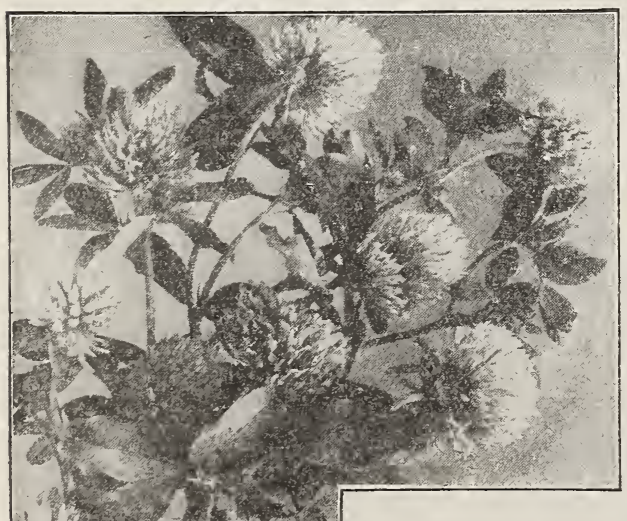
raisers is used on good land for a crop forage. It is very vigorous in growth, standing frost and drouth remarkably well, the tap root penetrating the soil very deeply, and occasionally used as a drainage plant for wet soils. It will grow on almost any barren hillside, in bottoms, and is equally adapted to all good farming lands. Sweet Clover is one of the most valuable crops for bees, being the main honey plant in many sections. We handle only the white blossom variety, which we consider the best. Sow 15 lbs, per acre. Hulled seed, 1 lb., 35c, postpaid.

YEITOW BIOSSOM SWEFT CIOVFR (Mellilotus Indica) -This is a variety of Sweet Clover, sometimes called Sour Clover, growing from 15 to 20 inches high, which is being used by many for quick results. It comes earlier, makes a full crop the first season. You can sow the seed in the fall or early spring. $1 \mathrm{lb}$., $25 \mathrm{c}$, postpaid.

BURS CIOVER-An annual variety which is sown in August and September. Makes superior pasturage, fair hay, and if turned under the following spring, acts as a splendid fertilizer. Grows on any thin land. Sow 10 pounds fancy sulled seed or 20 ponnds in the burr, to the acre. Hulled, 1 ib.s $40 \mathrm{c}$; in burr, 1 lb.. 25c, postpaid.

WIITE CIOVER-This variety is extremely valuable for permanent grass mixtures or those prepared for grazing land. It will stand more grazing than any other clover. As the growth is short it has
no value in a hay crop. Iuch is used in laws. Sow in spring, 4 to 6 pounds per 5.71 . 15 acre. $1 \mathrm{lb}, 75 \mathrm{c}$, postpaid.

CRIMSON CIOVER-Makes excellent green foliage, or if cut when in bloom will make good hay. Especially valuable for improving the soil, making a quick, heavy and very valuable crop for plowing under. Sow 15 pounds to the acre from July to November. Lb., $25 \mathrm{c}$, postpaid.

HUBAN CERTIFIFD SWEIT CIOVER-The new annual Sweet Clover of the White Blossom type. It is excellent for land improvement and also for hay. It makes a luxurious pasture and is relished by all kinds of stock. Owing to its earliness and profusion of fragrant blooms it is very valuable for bee raisers. $1 \mathrm{lb}$., $60 \mathrm{c}$, postpaid. 


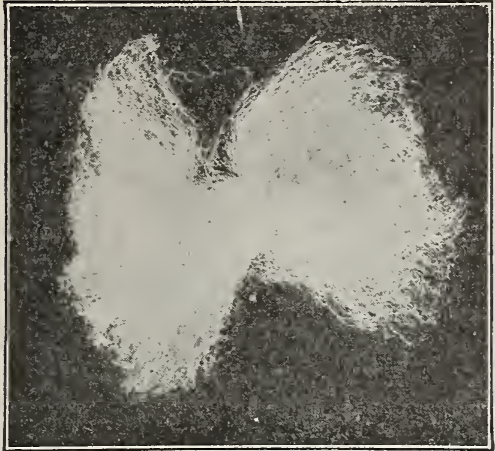

KING'S FARIY IMPROVID-A very early, small seeded variety, matures two weeks earlier than any other sort and nearly always thirds itself. On account of its extreme earliness it is largely planted in the boll weevil infested sections, as it matures most of its crop before the weevil makes its appearance.

HAIF AND IAIF-We recommend Half and Half the most valuable sort staple cotton ever developed to planters who prefer a short staple, or have the boll weevil to contend with. It is earlier than King's, and stands drouth better than the average varieties. On fertile land, with good seasons, its lint will run as high as 50 per cent. The staple is about 1 inch. We feel sure that anyone who plants Half and Half the coming season will be more than pleased.

SIMIXINS FARIY PROIIFIC-Originated also in Jarolina by W. A. Simpkins, and like King's Improved, from the old Sugar Loaf; in fact, King's and Simpkins are very similar in many ways-about the same shape and size plants, same size boll; extra early maturity and very prolific-hence its name. When you are looking for an extra early heavy yielding, short cotton, try this variety.

WANIAMAKER CIEVIIAND-Especially recommended for sections where the boll weevil is present. Plant is vigorous, thrifty, with low close-jointed basal fruit limbs; large bolls, easily picked, medium-sized seeds, grayish to greenish. The lint runs 34 to 38 per cent, is fine and strong, 1 to 1-16 inches long.

DEIFOS COTTON SFED-We have a wonderful offer for our patrons in the two types of Delfos Cotton Seed which was raised on the plantation of $\mathrm{Mr}$. $\mathrm{H}$. V. Phelps and his well known manager, Mr. W. M. Lang, has devoted a great deal of his time in an effort to produce a superior quality of seed. The seed was ginned at the private gin operated by Mr. H. V. Phelps and extreme care has been taken to keep it absolutely pure. If you are interested in pure Delfos Cotton Seed, selected types of 6102 or 631 , we advise you to book your order early as the supply is limited and we have started selling early this year. Delta Station, Miss., produced the wonderful Delfos 6102 after constant breeding for over a period of ten years and they truly produced one of the best types yet produced. Delfos produces a plant not over four feet high and it has held that standard of height on the strongest Delta. lands. It sets its fruit early on numerous lateral branches, beginning close to the ground. As it is very close jointed it will invariably produce a bowl to each joint. The foliage of Delfos Cotton is very light, resembling the willow leaf butter bean. The staple of type is practically speaking $33-16$ to $1 \frac{1}{1}$ full. Delfos Cotton will mature in about 100 days and its estimated lint is from 31 to $331-3$ per cent. The respective differences in the two types as we find them to be are as follows: 6102-Bowls upright, better for strong lands; 631-Bowls turned down, better for poor lands.

ACAIA No. 5 COTTON-Has given the most satisfactory results. It has proven to be a large boll variety and very early. The plant is of medium height with strong main stalk. The bolls large size ovate-oblong with short blunt point. The lint will puli strong $11-8$ inch and the percentage of lint will average $331-3$. It is considered one of the most desirable sorts to plant in sections infested by the boll weevil.

MEBANE EARIY TRIUMPF-For several years there has been an increasing demand for a tough-fibrecotton of medium staple; something between the ordi. nary short varieties and long staples. Mebane Triumph is ideal in this respect; pulls from $11-16$ to $11-8$ inches, has a strong, tough fibre, storm-proof and makes a gond "bender"' cutton, bringing good premium in price. Extra large boll, easy to pick, drouth resistant, lint out-turn at gin 37 to 39 per cent

EXRRRSS 350 -Express 350 is the best variety to use now, under weevil conditions, that is available in commercial quantities. Under favorable conditions it will mature in 90 to 100 days, being the best early staple cotton available. It pulls a full 1 3-16 inch staple of very even length, and will gin out 29 to 30 per cent lint.

SAISBURY FPDIGREED-This cotton is a cross between Wannamaker Cleveland and Express. The strong points of Salsbury cotton are these: It has the best staple of any short cotton grown and brings a premium; it is very early; it is disease resistant; has medium foliage; it is fast blooming and sets bolls early; it is very prolific; easy to pick and has large bolls; makes on our upland sandy lands a staple above one inch, in the Delta $11-8$ to $13-16$; has good ginning percentage; a magnificent quality of lint; high spinning value; the strongest lint ever produced.

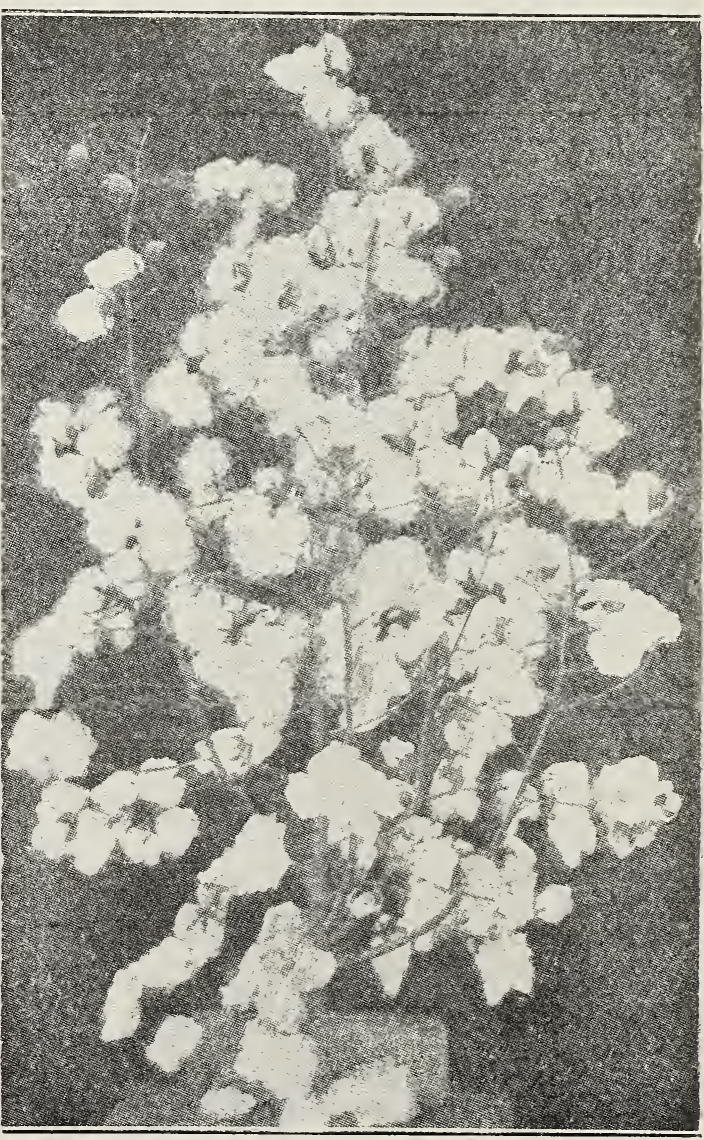

ifos Cotton 


\section{SOY OR SOJA BEANS}

The soy Bean is a legume, and in nutritive value is equal to Red Clover. As a soil improver, it is excellent. This plant will grow on a wide variety of soils, but the richer the soil the liarger the yield of forage.

The land should be prepared as for cow peas, and the seed planted in drills at a sufficient distance to permit one or two cultivations. One bushel of seed will plant two or three acres, the amount depending on the distance between the rows. The planting should be shallow, never more than one inch, or many of the seed will decay. This is a very important point to remember. Inoculation with soil from any old soy bean field is not usually necessary. If wanted for hay the crop should be cut when the upper leaves begin to turn yellow, but if wanted for seed the gathering should be delayed until nearly all the leaves have fallen. The hay is easily cured and is nearly as nutritious as Alfalfa hay. The seed planted in drills at a sufficient distance to permit cultivation, using $1 / 2$ bushel of seed per acre. It is also sown broadcast at the rate of one bushel to the acre. Soy Beans may follow a crop of rye or barley. Sowing thickly will prevent the stalks from growing too coarse, and will enable them to be harvested and cured to better advantage. Drill in corn rows. One peck to the acre will help MAMEMOTH YELLOW SOY BEAIS-The largest growing and most popular of Soja Beans for forage purposes. A little later in maturity than other kinds, but makes larger yields, both of forage and seed. Qt., 30c, parcel post paid.

OOTOOTAN SOY BEANS-This is the most remarkable and most valuable addition to Southern agriculture for many years. A Hawaian bean. It is a beautiful fast growing plant growing from 4 to 5 feet high, having fine stems and delicate leaves. It cares quickly and makes a hay of fine texture and splendid quality. For hay and grain combined the Ootootan is in a class by itself. The bean itself is quite small and jet black. One-half peck plants an acre. Can be planted any time from April 1st to August 1st. Qt., 50c, parcel post paid.

BIIOXI SOY BEANS-This bean is different from all other Soys, being larger in type and usually over 6 feet high, wide branching with much foliage. This extra foliage is of great advantage for the silo, for soil renew. ing, etc. Stems are large, but hollow and cure easily. Pods scatter seed very little; two weeks later than the Mammoth Yellow. A rank grower and fine for fall pas. turing, seed production and planting in corn for silage. One bushel usually plants 4 to 5 acres, three-fourths of a bushel broadcast. Price, $40 \mathrm{c}$ per qt., postpaid. LAREDO SOY BEANS-The new Laredo Soy Bean, after a thorough test, has proven to be the best all around Soy Bean and practically immune to root knot. The Laredo is different from any other variety. Plants get up a few inches high and stool out like oats and each individual plant sends up six to fifteen very fine branches making it one of the very best hay beans. Similar in some respects to O-Too-Tan in regard to seed, however, are a little smaller, black and flat. Very early. One bushel will plant about twelve acres in $2 \frac{1 / 2}{2}$ toot rows, 3 to 4 seeds to the foot in drills so the cost per acre is not so high in comparison to the other Soys. 1 quart, $75 \mathrm{c}$, postpaid.

\section{VELVET BEANS}

Velvet Beans make an enormous growth of vines; greater, in fact, than any other known forage plant, in

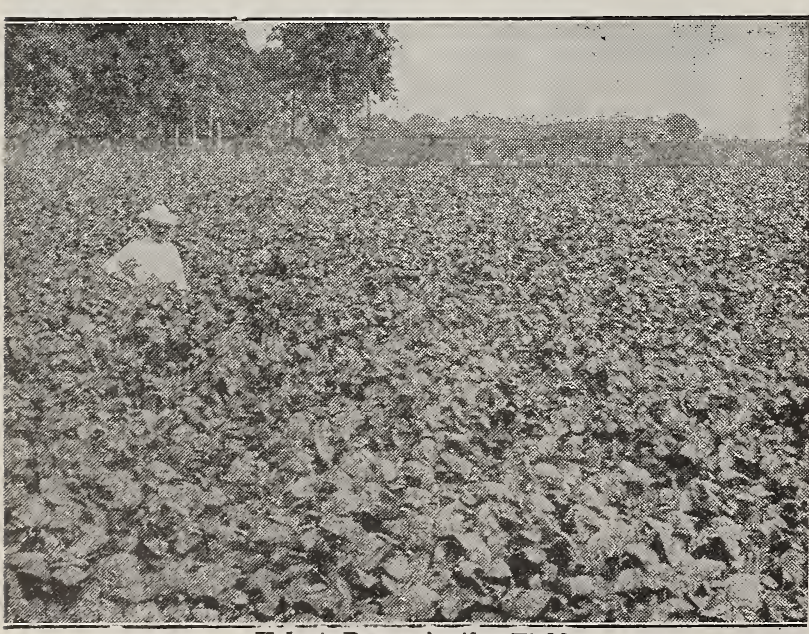

Velvet Beans in the Field

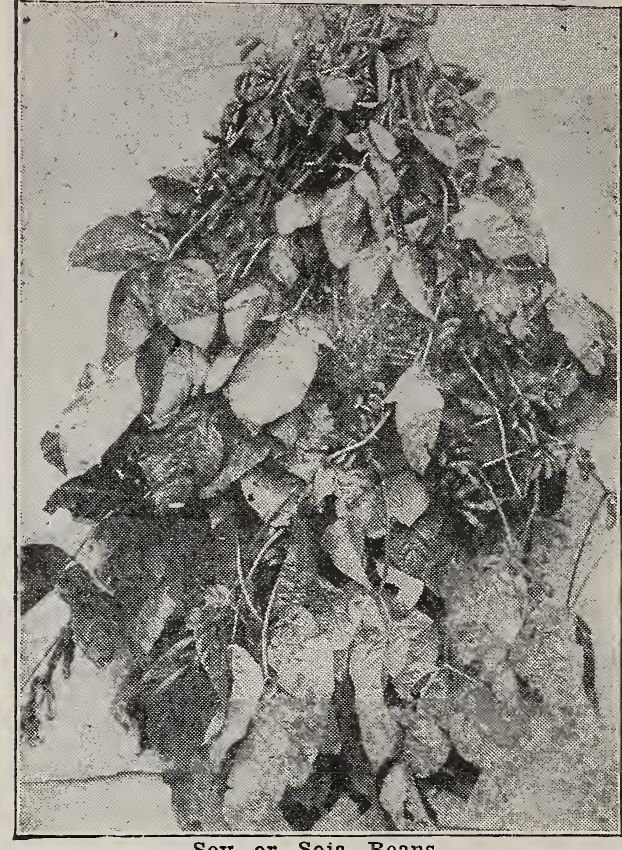

Soy or Soja Beans

the same length of time, far surpassing the cow pea in yield. Velvet Beans are usually planted in rows 4 to 5 feet apart, at the rate of about half a bushel per acre. As a soil improver they are considered superior to cow peas, as they make so much larger growth and so much heavier amount of foliage. The proportion of nitrogen contained in the vines is about the same as in cow peas, and as the yield is so much greater, the total amounts of nitrogen and humus added to the soil are correspondingly larger. A crop of three tons will add as much nitrogen to the soil as will a ton of cotton-seed meal. while the amount of humus will be three times as great. EARIY BIRD SPECrIID-This early speckled Velvet Bean is a variety that matures in 90 to 100 days, and can be grown in almost any part of the South. The Early Bird Bean may be planted in April or May, in the drill with corn, or in rows close to the corn, preferably after a rain, and cover shallow. The cultivation of the corn does the rest. The beans will begin to mature in July and will about have finished maturing October 1st, or before frost in any section of the Southern states. 1 quart, $30 \mathrm{c}$, postpaid.

OSCEOLA-This new velvet bean has several advan. tages over the early speckled varieties. It is free from the stinging fuzz or velvet on the pods, which makes the other varieties unpleasant to handle Large beans and pods make them less expensive to gather, and is also much earlier than most of the other beans. It is two weeks earlier than the other beans. It is two weeks earlier than the 100-day. Commences to get ripe about September 1st, and largely ripened by September 15 th; all ripe last September. Will make 25 per cent more beans than the 100-day. Blooms mostly purple. I qt., $35 \mathrm{c}$, postpaid.

GFORGIA BUSH VIIVIT BEANS-Grows up and stands sturdily as a bush, distinct entirely from the twining variety. The upright bush grows $3 \frac{1 / 2}{2}$ feet high with limbs branching from the bottom. Planted in the middle of 5foot corn rows, it fills the whole middle and does not interfere or strangle the corn. Can be grown for hay and the seed sown broadcast up to June 1 makes three times as much hay as cow peas. Also fine for winter grazing. Stock like it better than the vining varieties. The seed is a lit tle smaller and darker than the seed of the 100 day Speckled Velvet Bean. The pods are a little shorter and they have no sting whatever, very desirable feature. For hay, sow one bushel broadcast per acre in May or June. In the corn plant about April 15. After the corn is up, in the middles about one-half peck per acre. Price, it., $50 \mathrm{c}$, postpaid.

See pages 49 and 50 for Quantity Prices 


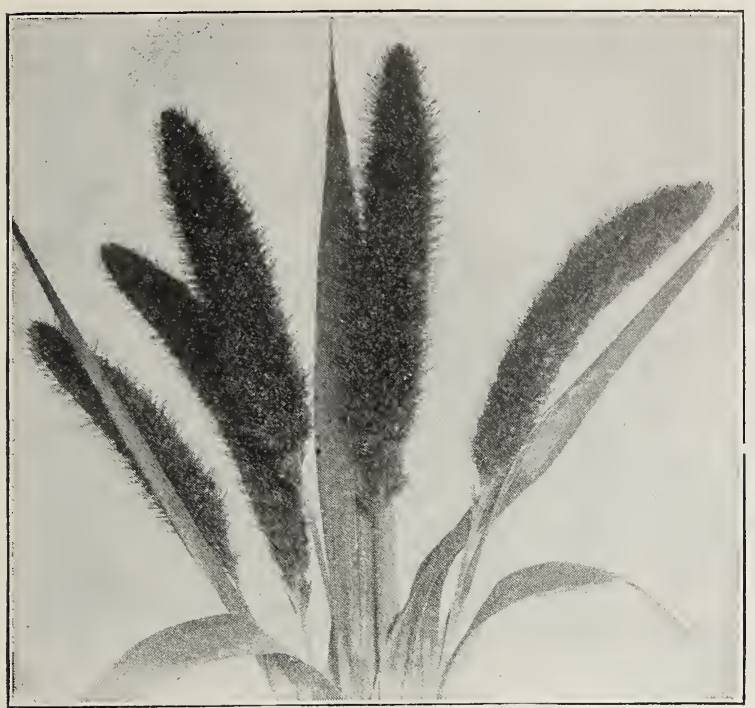

mennessee Golden IVillet

\section{解 RLLET}

Millet makes a large-yielding and most nutritious hay crop, quick growing and easily cured. It, however, requires to be seeded thickly - not less than 1 bushel per acre and the crop should always be cut while in bloom, before seed hardens in the head. If the seed is allowed to form the stalks get hard and it does not make nearly as good hay, and at the same time is more exhaustible to the land. Can be sown any time from the middle of April to the end of July. Do not sow too early.

TENNFSSF GOIDEN-Our Southern grown millet makes much better growth than the Western grown seed. This true Tennessee grown, a type that produces better quality, grows taller and gives a larger yield of very nutritious hay, is a quick grower. It should be cut for hay when it begins to show the heads. Plant from Apri] to August. The sowing of Southern Millet with cowpeas for a hay crop is increasing in favor each year. When this is done, use an early variety, such as Whip. poor-will or New Era, sowing about 3-4 to a bushel of millet with one bushel of Peas to an acre. Lb., 20e, postpaid.

WESTERN GOIDEN-This variety is very similar to the Tennessee Golden; however, it does not produce quite as much hay, and the heads are not quite so large. Lb. $20 \mathrm{c}$, postpaid.

PEARI or CAT-TAII-Is largely used for dairymen. Furnishing them green food throughout the summer. Should not be planted before May in warm soils, as it is a tropical plant, when it has reached the height of three to four feet, it will stool out enormously and make a rapid growth. In this way 3 or 4 cuttings a season can be obtained. It can be fed either green or cured as dried forage, making a most nutritious feed which is relished by all kinds of stock. Sow 5 pounds per acre in drills 3 feet apart or broadcast at the rate of 20 to 30 pounds per acre. Lb., 35c, parcel post paid.

JAPANESI or BARNYARD MIIIFT-This is a forage plant of great value, growing in most any soil. It has been known to produce 3 to 5 tons of fodder if planted early. After second cutting it will afford a pasturage all the fall. It is relished by all stock, and is sometimes called the Billion Dollar Grass. $1 \mathrm{lb}$., $30 \mathrm{c}$, postpaid.

\section{MAFFIR CORN, MILO MAIZE}

\section{WHITE KAFFIR-Grows 4 to 5 feet high. The stems} are very leafy and keep green and brittle, unlike other sorghums, which barden. Makes excellent fodder, eithey green or dried. For fodder, sow from $1 / 2$ to 1 bushel, either broadcast or in drills. Lb., $25 \mathrm{c}$, postpaid.

RED KAFIIR-Grows taller than the white; stalks slender, juicy and very leafy. Ripens earlier than that of the white and yields much heavier. Lb., 25c, parcel post paid.

YEIIOW MIIO MAIZE-A non-saccharine sorghpm of high value. It is a vigorous grower, of deep green color, attaining a height of 8 to 10 feet. Plant in April, May or June, 6 to 8 pounds of seed to an acre in drills. Lb., 20c, parcel post paid.

EGYPTIAN WHEAT or SHALLU-A valuable new grain, entirely different from wheat. The heads are large and heavy. All stock love it, and do well. It makes heus lay better than any poultry food. It will stand more wet or dry weather than maize or cane. Plant in drills 3 feet apart, using ten pounds of seed per acre, or broadcast, using from 2 to 4 bushels. Lb., 35c, parcel post paid.

FETERITA-This wonderful new non-saccharine sorghum is somewhat similar to Kaffir Corn, with the exception that the grains are somewhat larger and softer than Kaffir Corn, and it is preferred by many on this account for feed in the head. It is about three or four weeks earlier than Kaffir Corn. It is undoubtedly the most drouth-resisting of any of the sorghum family. Sow in April or May in drills, 5 pounds to the acre. Lb., $25 \mathrm{c}$, parcel post paid.

\section{SORGHUM OR CAR ER E}

TEXAS SEIDID RIBBON-This cane gets its name from being a variety that closely resembles the true Ribbon Cane, raised from cuttings. It inakes the finest kind of syrup. Lb., 25c, parcel post paid. JAPANESP HONEY - This variety of cane is with out a doubt the best all-around cane for the Southern farmers. It is the very best syrup producer of all of the varieties and is also a splendid forage crop for green feeding, making excellent hay if sown in drills very thick, and may be planted any time between April and August. It grows 10 to 12 feet high and is very prolific, sometimes producing five to seven stalks from one seed. Matures about the middle of August to October, owing to time of planting, but will keep green and stand, if desired, until killed by frost, allowing the farmer to take his own time to harvest for syrup. As a syrup producer it has no equal, being exceedingly juicy and sweet, making from 200 to 400 gallons per acre, highly flavored. Lb., $25 \mathrm{c}$, parcel post paid.

EARIY ORANGE-A variety well adapted for the South. It is from 8 to 10 days later than the Early Amber. Largely used for hay and fodder. Lb., 20c, parcel post paid.

F!ARIY AMBIR-Farmers and stockmen say that the carly Amber is the most valuable fodder plant in existence. It is profitably grown from Manitoba to Mexico on any good corn ground, and it is but little affected by drouth. Lb., $20 \mathrm{c}$, parcel post paid.

RED TOP SORGHUM- Frown extensively in Middle Tennessee. Very sweet and one of the best for hay. Lb., $20 \mathrm{c}$, parcel post paid.

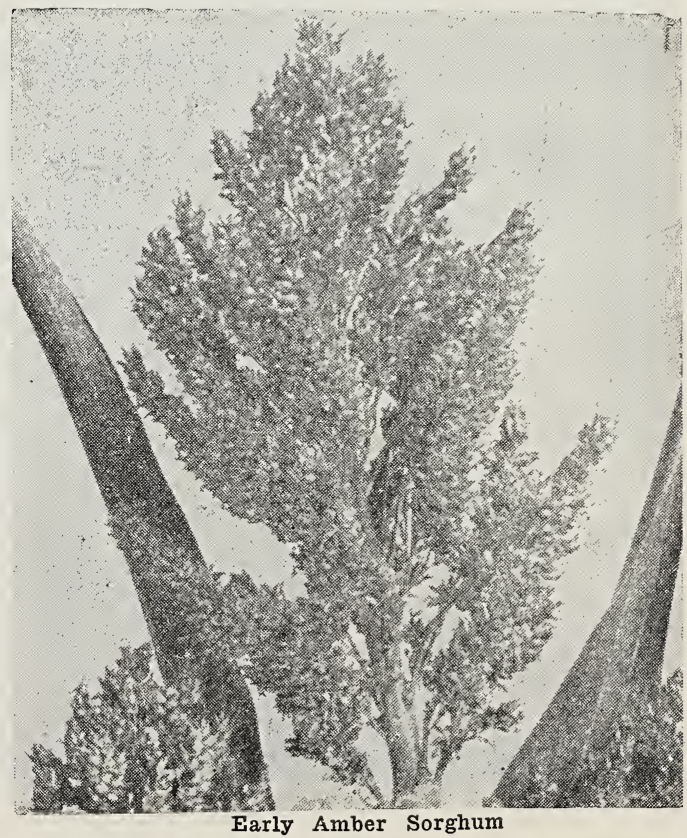

ABOVE 


\section{PEANUTS}

Prepare the ground well, laying it off in rows with a shovel plow; the rows should be $3 \frac{1}{2}$ feet apart, and put two kernels to the hill, which are about one foot apart. Cultivate thoroughly and keep the land as level as possible. One and one-half bushels of unshelled nuts will seed an acre.

SPANISH-In addition to their value for growing for nuts these are very largely used in the South as a forage and fattening crop for hogs and other stock. They are early to mature very productive, and in the far South, where they can be planted during March and April, two crops can be made in one rear, the second crop being planted early in July, the tops making a has crop and the nuts a grain crop. They grow more compact than the Virginia Peanuts, making it possible to grow then closer, making the cultivation easier also. This variety frequently rields sixty bushels of marketable peanuts and two tons of hay per acre. Lb., 25c, postpaid.

TENNESSEE RED-The finest variety grown. Especially adapted to the black, waxy land as well as the sandy soil. The nuts contain three large kernels in each and are enormously productive. Lb., $30 \mathrm{c}$, parcel post paid.

MAIIMOTH WHITE VIRGINIA-Largest size; white variety. Lb., $30 \mathrm{c}$, postpaid.

\section{COW PEAS}

Sow in May, June and July, at the rate of one-half bushel to the acre. The value of cow peas as a soil enricher is now well known. As fast as farmers understand the advantages of this plant as an agency through which the value of their land may be greatly increased, there will be more successful farmers and more profitable farms. It adds nitrogen to the soil at less cost than any other method. Cow peas make excellent hay.

Prices on cow peas given on application Let us know how many you will need.

WHIPPOORWIII-A favorite early bunch-growing variety. Seed is reddish brown speckled. A great favorite on account of its early maturity.

NNW ERA-An early, upright-growing variety. The seed is smaller. It is not inclined to run. Matures in sixty to seventy-five days.

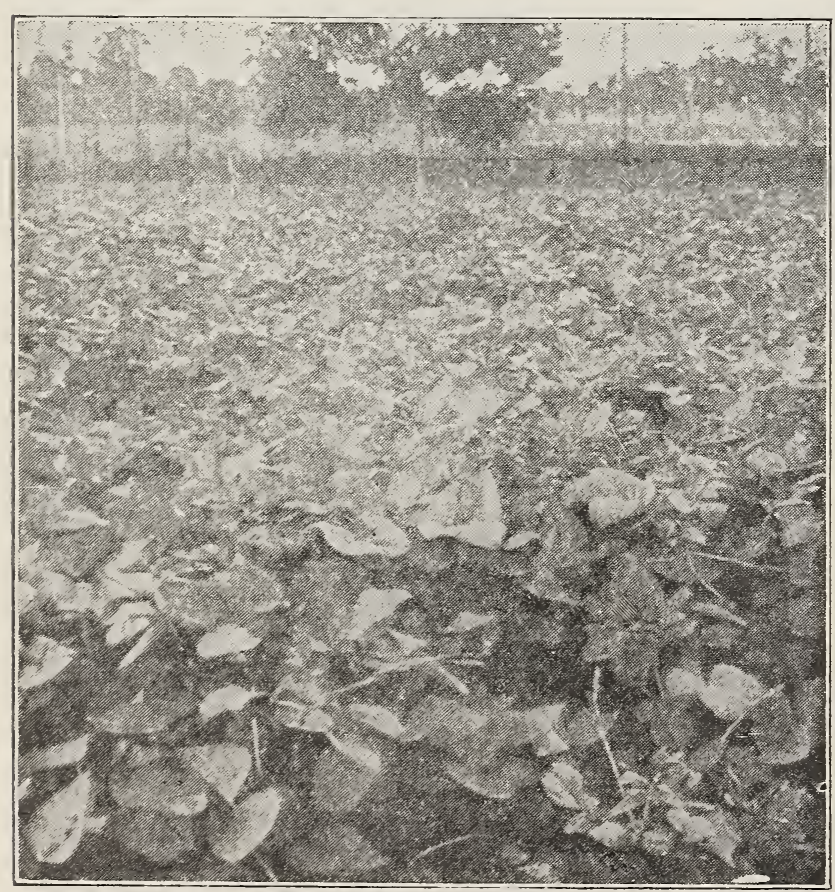

Whippoorwill Cow Peas

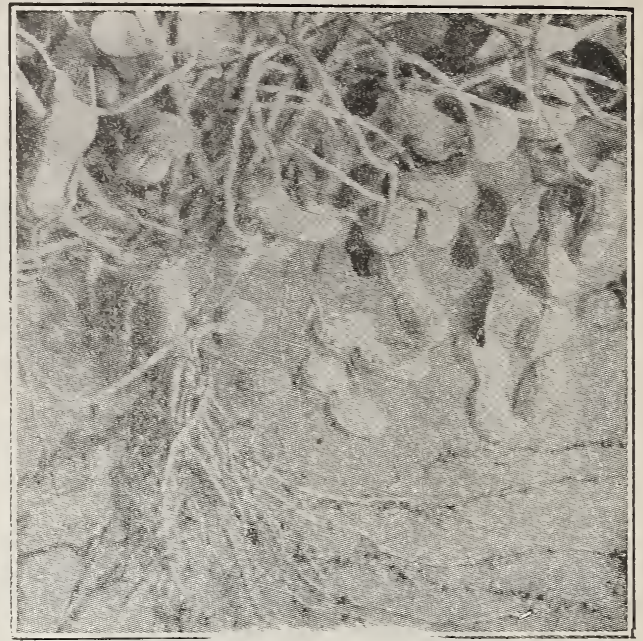

Spanish Peanuts

EIACK STOCK-This is a large, late-vining variety. The vines grow very long. Best for thin land.

CIAX-Very similar to the Unknown but earlier; vig. orous growth; very popular.

RED RIPPERS-One of the most prolific varieties of cow peas. Vines grow long; make an abundance of hay MIXID-Preferred by many farmers where the crop is intended for soil improving; they will grow thicker than separate varieties, producing better crop of vines: and forage.

\section{WHITE TABLE PEAS}

CAIIFORNIA IARGE WEITR BIACKRYF-Very large, kidney-shaped peas, maturing the earliest of all fine for early market. Qt., 40c, postpaid.

WIITE BROWN-EYRD-A desirable table pea. Pru lific. Qt., $35 \mathrm{c}$, postpaid.

WHITE IADY PEAS-Very small seeded but strong growing and prolific pea for table use. Peas are creamy white and of the finest quality. Qt., 50c, postpaid.

CROWDER PFAS-Exceptionally fine for table use. Prolific and very sweet. Qt., 60c. postpaid.

\section{FIELD BEANS}

IIUNG BEAI-Wonderful new bean for forage. Heavy seeder, grows well on light or clay soils, produces tremendous quantity of nitrogen nodules on its roots. Beans are excellent for table use. Matures in 90 to 100 days, a little earlier than speckled pea, but can be planted at any time and the same way as cow peas. Plant grows upright like soja hean, making it easy to cut with blade or machine. Leaves stay on stalk well while being handled. 1 lb., $50 \mathrm{c}$, postpaid.

CASTOR BEANS (Ricinus or Castor Oil Bean)-Plant like corn. in March and April; use $1 / 2$ peck of seed to the acre in rows 4 feet apart; thin plants to 24 inches. The plant prefers a rich, well drained sandy or clay loam. Qt., 55c, postpaid.

\section{FIELD PEAS}

CANADA FIFID PEAS-Every year there is more inquiry for field peas. As a fertilizer they come next to clover, to be plowed under when they commence to blossom. They will grow on land that will not produce clover. Sow $1 \frac{1 / 2}{2}$ to 2 bushels to the acre: or, if with oats, sow 1 bushel of each. Qt., $40 \mathrm{c}$, postpaid. 


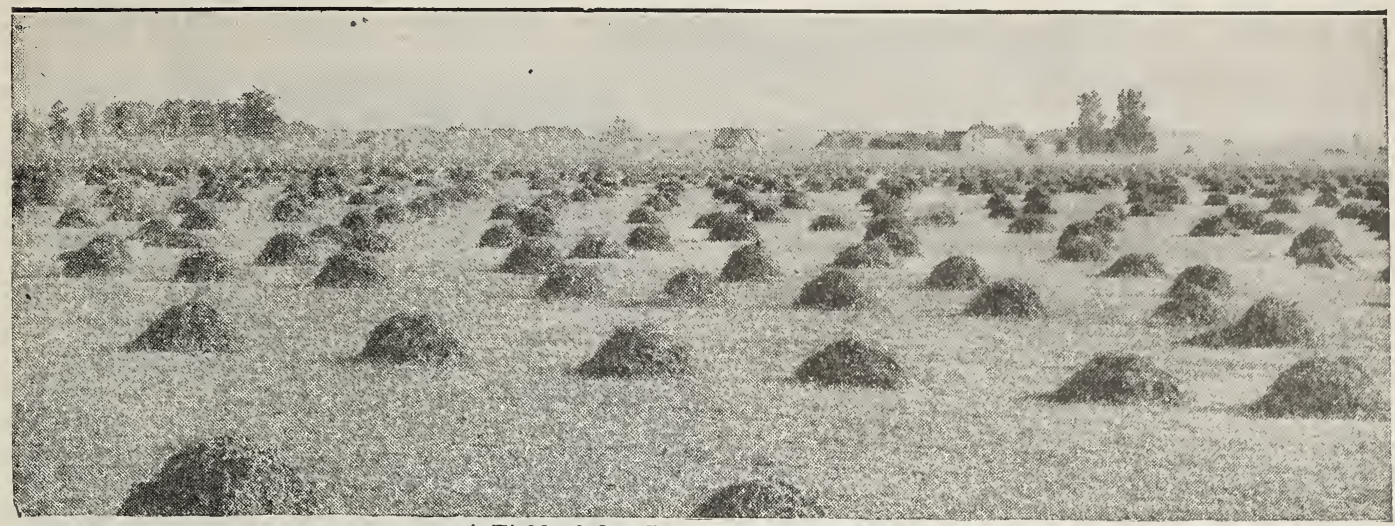

A Field of Our Red Rust Proof Oats

\section{Miscellaneous Farm Seeds}

We have grouped together for the convenience of our customers all the various farm seeds. If larger quantities are wanted than prices quoted call for, we will be pleased to quote further upon request.

FARIY BURT OATS-The quickest growing, most prolific and surest cropping of Spring Oats. Good for thin land. Sow 2 bushels to acre.

RED RUST PROOF OATS-These oats are very popular throughout the South. They do well on any good land and are very productive. They are sown both in the spring and fall at rate of 2 bushels to acre.

APPIER OATS-A very hardy variety, rust proof and a heavy yielder. Matures ten days earlier than native rust proof and about a week later than Burt. WINTER TURF OATS-This oat is unsuited for spring planting. They are best planted in the fall and will furnish excellent winter and spring pasture.

IMP. EVERGRIFN BROOM CORN-A favorite in all sections. Grows to a good length and, if cut at the proper time, retains a good color.

Six pounds of seed are required for an acre when drilled in rows feet apart. $1 \mathrm{lb} ., 25 \mathrm{c}$, postpaid.

DWARF OKLAFOMA BROOM CORN-This variety grows only 3 or 4 feet high, and is much easier handled than the tall growing sorts. The bush is straight, smooth and of good quality. $1 \mathrm{lb}, 25 \mathrm{c}$, postpaid. SPRING VETCF - Better for spring sowing than the Winter Vetch. A nutritious and valuable forage and soil-improving crop. Large and quick growth. Sow 50 lbs. to the acre. $1 \mathrm{lb} ., 30 \mathrm{c}$, postpaid.

SAND Or FAIRY VFTCH-SOW from July to November, preferably with grain, which will hold vetch off the ground. Sow $50 \mathrm{lbs}$. to the acre. With grain, 1 peck to the acre. 1 lb., 30c, postpaid.

JAPE, DWARF ESSEX-This is an ideal sheep feed, easily grown; perfectly hardy and possesses remarkable fattening properties. Any corn soil will grow rape. Sow the seed any time in March and by the end of June, and the crop can be ready to feed at a season when it is most needed. It does well sown with oats. After oats are cut the Rape grows rapidly. If the soil is rich and clean, sow broadcast; if not so clean, sow in drills and cultivate as for corn. When sown broadcast use 6 pounds, and if in drills, 2 lbs. to the acre. 1 lb., $25 \mathrm{c}$, 10 lbs., $\$ 1.50$, postpaid.

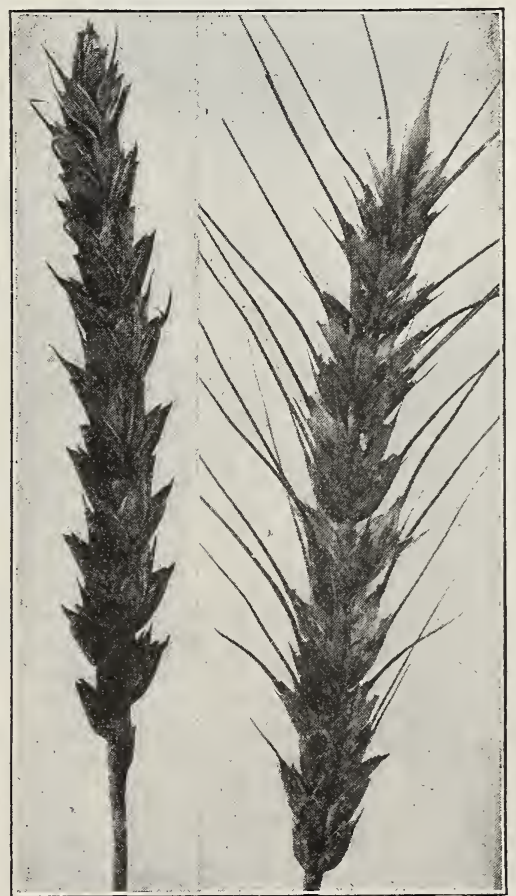

Ba-ley
SERD RYF-Makes excellent pasture for all classes of stock. Sown mostly in the fall, beginning about September and sowing up to December. We handle three varieties-Missouri, Abruzzi and Rosen. Prices quoted on application; also any other information.

CHUrAS-Much used to fatten hogs. Plant in April, 12 inches apart, in 3-foot rows. Should be soaked before planting. One peck of seed per acre. Lb., 50c, parcel post paid.

JAPANESE BUCKWHEAT-Sow in April, May or June 1 bushel broadcast to the acre $1 \mathrm{lb}, 25 \mathrm{c}$, postpaid.

SIIVIR FUII BUCKWHAAT-Splendid for bees, also makes best grain. Sow in June, 1 bushel, broad. cast, to the acre. $1 \mathrm{lb} ., 25 \mathrm{c}$, postpaid.

SPEITZ or FMMIER-Matures as early as Barley and grows as tall as Rye, but is of better feeding value than either. It is tough and hardy and stands drouth better than any other grain. Sow in March, 1 bushel to the acre, broadcast. 1 lb., $25 \mathrm{c}$, postpaid.

BRARDIESS B A R I $\mathbf{Y}$ - It makes a quick growing crop of most excellent and nutritious feed, either to use green or to cure as hay. Sow $1 \frac{1}{2}$ to 2 bushels per acre. $1 \mathrm{lb}, 20 \mathrm{c}$, postpaid.

RUSSIAN SUNFIOWRR-Plant in March, April and May, 6 pounds of seed to the acre, making rows $3 \frac{1 / 2}{2}$ feet apart, dropping 2 seeds every 18 inches: cultivate like corn. 1 lb., 25c, postpaid.

TFOSINTr-A valuable continuous cutting forage plant for Southern and Southwestern States, furnishing a most nutritious food, green or dry for horses and cattle. It resembles Indian Corn, the leaves heing larger and the sap sweeter. Sow in May or June, in drills, $3 \frac{1}{2}$ to 4 feet; 2 to 3 lbs. per acre $1 / 1$ lb., 35c; 1 lb., 85c; 5 lbs. $\$ 3.70$, postpaid. Not prepaid, $1 \mathrm{lb}$., $75 \mathrm{c} ; 5$ lbs., $\$ 3.50$.

\section{SPICIAI NOTICE}

For quantity prices on all varieties of seed listed on this page see page 50 . We will be glad to furnish our customers any information desired regarding seeds. 


\section{Fruit Trees, Berries, Grape Vines and Shrubs} sent one of the largest and most reliable nurseries in the South.

Terms are strictly cash, F. O. B. growing station. No trees shipped C. O. D.

Set out small trees. They are more certain to grow and will bear fruit just as early as any large or older tree. It is a mistake to reset any trees older than two years.

\section{APPLES}

2-year-old Trees______-_._Each, 70c; 10 for $\$ 6.00$ SUMIMER VARIETIES

Duchess of Oldenburg-Yellow, striped red. July.

Early Harvest-Fine yellow; ripens in June.

Horse-Large, yellow, fine for cooking; ripens in August. May Pippin-Is greenish yellow; ripens in May and June. Red Astrachan-Greenish, covered crimson; ripens in June.

Red June-Dark crimson, fine grain, moderately juicy. FALI VARIETIES

Bell Flower-Oblong, fine rich yellow, juicy, acid.

Fall Pippin-Large, yellow; ripens in September.

Rome Beauty-Large, red, white flesh. A fine apple.

Yates' Mammoth-Richly striped; ripens in November.

\section{WINTER VARIETIES}

Arkansas Beauty - Large, bright red; succeeds well.

Arkansas Black-Large, dark crimson; flesh jellow.

Ben Davis-Large, greenish yellow, striped with red.

Grimes Golden - Golden yellow, crisp, tender and juicy.

Jonathan-Large size; rich color, handsome variety.

Winesap-Rich, dark red, flesh fine, creamy yellow.

Staymen Winesap-Similar to Winesap, better quality.

Delicious-Very large, oblong, rich crimson, shaded to Jellow.

\section{CRAB APPESS}

Each _-

Ten -

Golden Beauty, Red Siberian and Yellow Siberian.

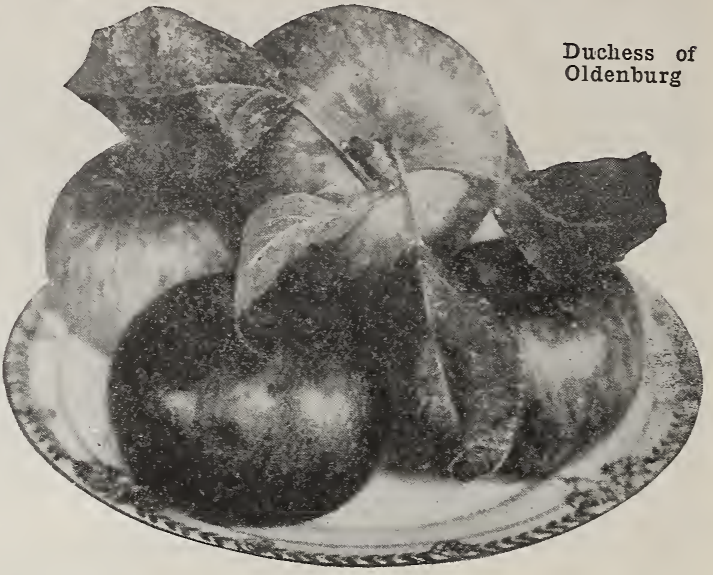

CHERRIES

2-year-old Trees_-_-_-_-_Each $\$ 1.00 ; 10$ for $\$ 8.50$ Black Tartarian-Black, juicy; ripens last of June. Early Richmond-Fine, very early; ripens in May.

Governor Wood-Vers large; ripens last of May.

Late Duke-Light red; ripens last of June.

May Duke-Large, dark red; ripens in May.

\section{JAPANESE PERSIMMONS}

The Japanese Persimmon is thoroughly adapted to the Cotton Belt. The fruit varies in color and shape. We offer two of the best kinds, well adapted to this latitude, in four distinct sorts. Price, 2 to 4 feet, each $\$ 1.00$; ten for $\$ 9.00$.

\section{NECTARINES}

Early Richmond Cherries
Strong 2-year-old trees, each, $75 \mathrm{c} ; 10$ for $\$ 7.00$.

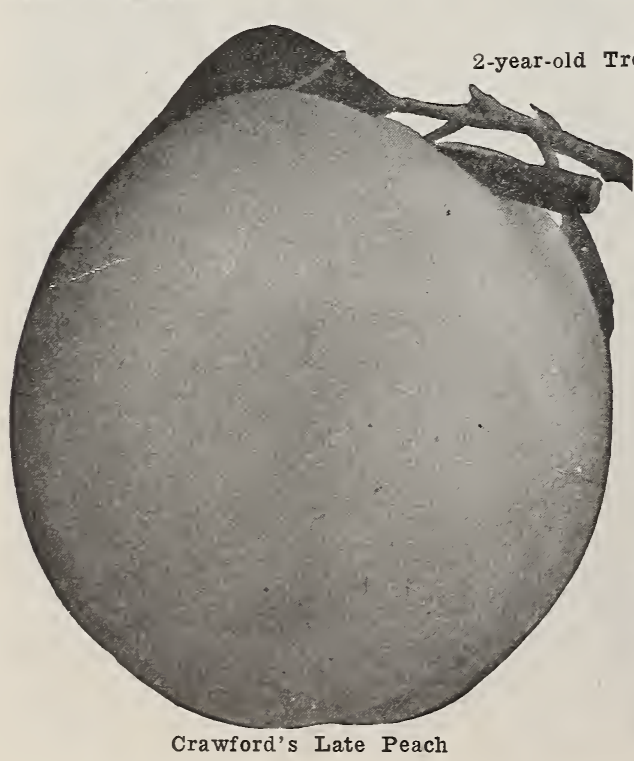

\section{PEACHES}

\section{CLINGSTONES}

Chinese Cling-Delicious creamy white; ripens about July 15 Fitzhugh Lee-Creamy white with crimson blush. Ripen July. Feath Cling-Pale rellow; fine grain; ripens in September. Indian Blood-Very large, dark crimson color; ripens August. Lemon Cling-A deep sellow peach that ripens end of July. Levy's Late-A fine, large late variety that ripens in October. Morris October-One of the best; ripens about October 1 . Old Mixon Cling-Yellowish white; ripens in August.

\section{FREESTONES}

Admiral Dewey--Orange yellow with crimson cheek. June 15. Belle of Georgia - Large white peach ripening July 20. Carmen-Large freestone of delicious flavor; ripens in June. Crawford's Early-Yellow, juicy, sweet; ripens August. Crawford's Late-Finest quality peach; ripens August 20. Elberta-Flesh yellow, juicy and sweet; ripens August 1. Greensboro-Early variety, large white; ripens June 15. Heath Free-Very tender, juicy and melting; ripens September. old Mixon Free-Yellowish white; juicy; ripns about August 15. Piquet's Late-Flesh yellow, sweet; ripens September. Yellow St. John-Golden yellow; ripens June 20. 


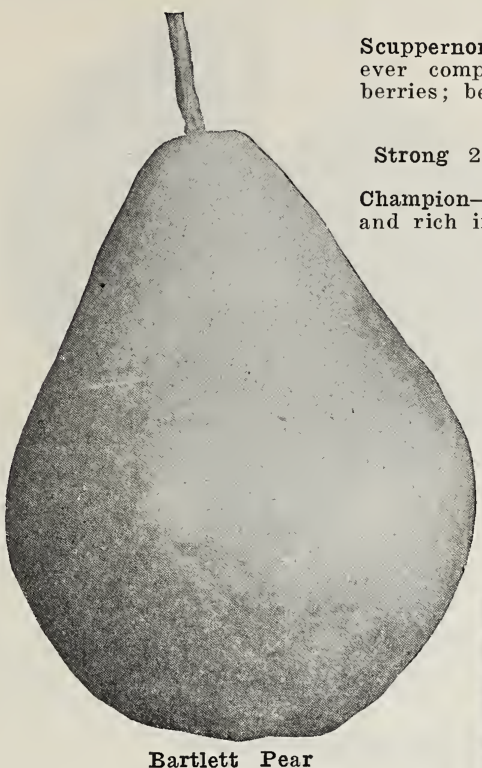

APRICOTS

Strong 2-year-old Trees, each, $\$ 1.00$; fo: $\$ 7.50$.

Early Golden-Small, pale orange, juicy and sweet.

Moorepark-Medium size, good keeper. Russian-Of best quality, ripens early very productive.

\section{PLUNS}

2-year-old Trees, each, 80c; 10 for $\$ 8.50$.

Abundance-Large, sweet, juicy; very early, bright red.

Burbank-Large, clear, cherry red, very sweet.

Damson-Bluish purple, fine for cooking; ripens in August.

Red June-Purplish red, flesh yellow, solid, juicy.

Wild Goose--Very large and fine; ripens in June.

\section{FIG BUSHES}

\section{SCUPPERNONG GRAPES}

Grapes-Bunches seldom when full ripe; vine is free from all diseases and attacks of insects. 2-year, each $\$ 1.00 ; 10$ for $\$ 9.00$.

\section{QUINCES}

10 for $\$ 9.00$.
year-old Trees, each, $\$ 1.00$; Orange-Large, round, golden yellow:
very fine. 10 for $\$ 9.00$

Rea's Mammoth-An improvement upon the Orange; much larger.

\section{GRAFTED OR BUDDED PECANS}

The budded or grafted pecan will bear at six years of age, while the seedlings seldom commence to give fruit under ten years after planting. Price, 2 to 3 feet, $\$ 1.50$ each, ten for $\$ 12.50 ; 3$ to 4 feet $\$ 2.00$ each, ten for $\$ 17.50$.

Bradley Pecan-Its good points are large size, thin shell, well filled and very prolific.

Frotscher Paper Shell Pecan-One of the best; large, thin shells; prolific bearing.

Pride of the Coast-Nuts frequently 2 inches in length; shell moderately thin; nuts will run from 24 to 32 to the pound.

\section{STRAWBERRIES}

Plant in February, March. April and November, on good ground, deeply

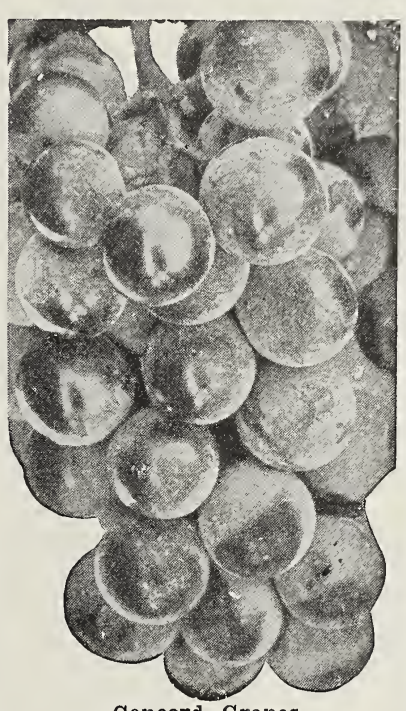

Concord Grapes worked and well manured. Set in rows $3 \frac{1}{2}$ feet apart, 15 inches in rows, for field culture; 15 inches each way for garden. Cultivate clean, mulch late in the fall and uncover early in the spring. Remove mulch after fruiting and spade in a light dressing of manure.

Any of the following varieties: 50 for $60 \mathrm{c}, 100$ for $90 \mathrm{c}, 500$ for $\$ 2.75,1,000$ for $\$ 4.85$, parcel postpaid. Not prepaid: $100,75 \mathrm{c} ; 500, \$ 2.50 ; 1,000, \$ 4.50 ; 2,000$, $\$ 8.00 ; \quad 5,000, \quad \$ 17.50$. Special prices quoted on larger quantities.

Aroma-Large size dark red; one of the best of the late sorts.

Exicelsior-Extra early; high color; vig orous grower; drouth resister.

Brandywine-Large, highly productive.

Lady Thompson-Very popular.

Klondyke-Dark red berry of uniform size and one of the best shippers.

Lady Corneille-New Strawberry from Louisiana; ripens with Klondyke, but bears longer; berries large, rich, glossy red, slightly long; rich, juicy, sweet.

Gandy-Last to ripen; large, firm.

Progressive Everbearing-Best of the Everbearing sorts. Price: 25 for $75 \mathrm{c}$; $50, \$ 1.25 ; 100, \$ 2.25 ; 500, \$ 6.50$, parcel post paid. Not prepaid: $25,60 \mathrm{c} ; 50$ $\$ 1.10 ; 100, \$ 2.00 ; 500, \$ 6.00 ; 1,000$, $\$ 10.00$.

Price either variety, 1-yr.-old trees, each $\$ 1 ; 10$ for $\$ 8.50$ Brown Turkey-Medium size, very sweet, prolific, hardy. Celestial-Very large, violet, good and productive.

Lemon-A beautiful lemon-colored fig, very sweet.

\section{STANDARD PEARS}

2-year-old Trees_________..._Each, 80c; 10 for $\$ 7.50$ Bartlett-Yellow, faint blush; ripens in August.

Clapp's Favorite-Resembles the Bartlett; ripens in August. Duchess D'Angouleme-Very large; ripens in October. Garber-Larger than Keiffer; a beautiful yellow pear. Koonce-Of large size and good form and color.

Keiffer-Golden yellow, tinged with red on one side, remarkably free from blight; ripens in September.

\section{GRAPES}

Strong 2-year-old vines; price, by express, each $40 \mathrm{c}$; 10 for $\$ 3.50$.

Brighton-Large, coppery red color; best of quality. Delaware-Bunches small and compact; light red; juicy. Moore's Early-Large, black, earlier than Concord; fine. Niagara-Berries are large, sweet and greenish white. Worden-Concord type; very large in bunch and berry. Concord-Large, black, juicy berries; sweet when ripe. Lutie-Very early, large red; free from rot.

Campbell's Early-Large, compact, back berry.

Early Ohio-The earliest black grape; bunches large.

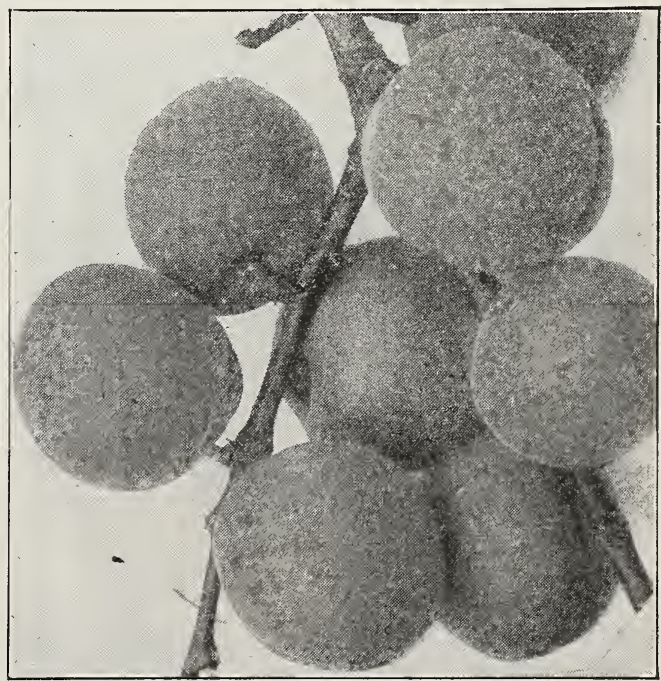

Abundance Plums 


\section{RASPBERRIES}

Plant in rows 5 to 6 feet apart, 2 to 4 feet in the row. Cut the tops off within few inches of the ground when planted. Ifter the fruit season, cut out all the old wood which bore the last crop of fruit. Pinch the vigorous young shoots several times during the summer. They will then grow stout enough to stand without staking.

Cumberland-The largest black raspberry grown; immensely productive: quality fine; ripens very early. Price, by express, 10 for $\$ 1.00 ; 100$ for $\$ 9.00$.

St. Regis Everbearing Raspberry-One of the greatest raspberries ever introduced. Plants of the St. Regis put out in the fall or early April gave ripe berries on the 20 th of June. For four weeks thereafter the yield was heavy and the canes continued to produce ripe fruit without intermission until late October. The berries were lirge and beautiful, firm and full flavored, to the very last. The St. Regis is the only raspberry, as far as known, that is practically sure to produce a crop of fruit the season planted. Price, by express, each, 20c; 10 for $\$ 1.50 ; 100$ for $\$ 10.00$.

Cuthbert-Fruit large, red, of excellent quality, yield very prolific; ripens middle of May, and continues for several weeks. Price, by express, 10 for $\$ 1.00 ; 100$ for $\$ 9.00$.

Gregg-Blackcap; very productive, large size, firm, black. Price, by express, 10 for $\$ 1.00 ; 100$ for $\$ 9.00$.

\section{BLACKBERRIES}

Plant in good soil, in rows 5 to 6 feet apart, and 3 to 4 feet apart in the row. After the fruiting season, or in early spring, cut out all the dead wood. Black: berries should be planted early, before the buds start. A good top dressing of stable manure, applied annually, will be conducive to large crops. Keep the ground clean. Himalaya Giant-A mammoth late blackberry, coming after the other berries are gone, ripens over a period of several weeks, making it especially desirable for family use. Fruit large, fine quality. Price, by express, 10 for $\$ 1.25 ; 100$ for $\$ 10.00$.

Eldorado-Fruit large, roundish conical, rich glossy black; firm, juicy, sweet and excellent. Price, by express, 10 for $\$ 1.25 ; 100$ for $\$ 10.00$.

Early Harvest-The earliest good blackberry, fruits well, of excellent quality. Price, by express, 10 for $\$ 1.25$; 100 for $\$ 10.00$.

\section{MEDGE PLANTS}

Amoor River Privet-The test of the Privets for planting in the South. This type retains its bright green foliage almost all winter here.

Price, by express only-

12 to 15 inches 18 to 24 inches 30 to 36 inches California Privet-The great hedging plant. Remarkable for the beauty of its evergreen foliage and strong, reg. ular, symmetrical growth. The foliage is dark green, very glossy and wax-like; hardy everywhere. Remove the unsightly fence and increase the value of your property by planting a California Privet Hedge. Does well in all situations and under all conditions.

Price, by express only-

12 to 15 inches 18 to 24 inches_._. 30 to 36 inches

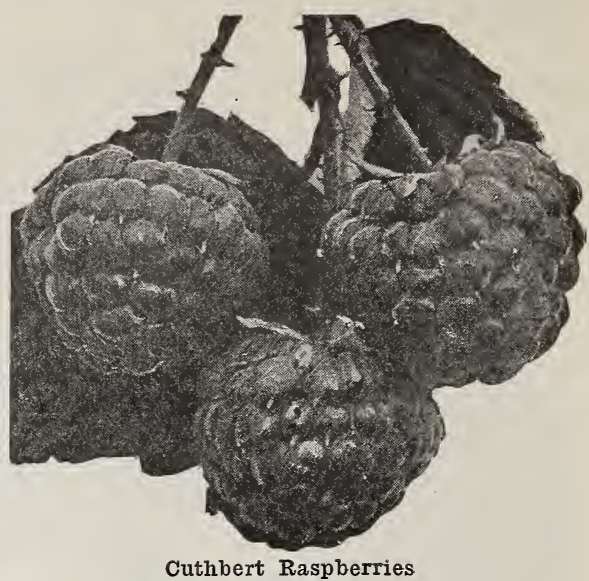

DEWBERRIES

Lucretia Dewberry-The berries are far larger and incomparably better than any blackberry, and of unequaled excellence; soft, sweet and luscious throughout; of brightest glossy black color. Price, by express, 10 for $\$ 1.00$; 100 for $\$ 9.00$

\section{GOOSERERRIES}

Downing-Large, pale green berries. Price, by express, each 50 c; 10 for $\$ 4.00$.

\section{MULBERRIES}

Price, each, $\$ 1.00 ; 10$ for $\$ 9.00$.

Hick's Everbearing-Produces immense crops; splendid for poultry and hogs.

\section{ORNAMENTAL TREES, SHRUBS}

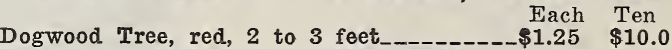

Persian Purple Ieaf Plum, 5 to 6 feet....- $1.50 \quad \begin{aligned} & \$ 10.00 \\ & \text { Plum }\end{aligned}$

Becktel's Ornamental Flowering Crab,

3 to 4 feet._.

Butterfly Bush or Buddleia.

Blue Spirea

Hydrangea, Hill of Snow

Hydrangea, Paniculata, Grandifiora_...- $\quad .50 \quad 4.00$

Honeysuckle Bush _-

White Kerria -

Vitex Agnus Castus or Hemp Tree..... $\quad .75 \quad 6.00$

Exochoida Grandiflora, Pearl Bush

Althea, in 10 colors, each, Rose or Sharon $.50 \quad 4.00$

Calycanthus, sweet shrub, clove or allspice $\quad .50 \quad 4.00$

Crepe IMyrtle, crimson, pink, white_...- $.75 \quad 6.00$

Deutzia, assorted colors___..._____-... $.75 \quad 6.00$

Forsythia, Golden Bell

Japan Quince -

Lilac, purple, pink and white_._-

Philadelphia Syringa

Snowball Shrub _.... 75.600

Spirea, assorted

Weigela, assorted

\section{SHADE TREES}

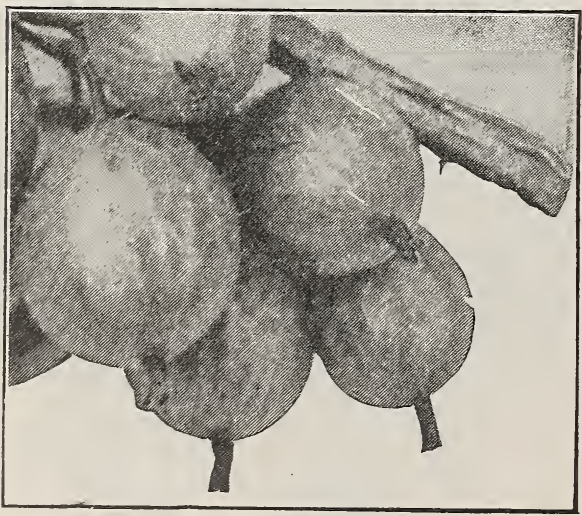

Downing Gooseberries
Price, Trees 4 to 6 feet, $75 \mathrm{c} ; 8$ to 10 feet, $\$ 1.00$ : each Silver Leaf Maple White Ash Red Elm Lombardy Poplar Black Walnut Weeping Willow Carolina Poplar Elm, Am. White Sugar or Rock Maple

\section{EVERGREENS}

Sold only balled and baled, so will transplant safely. Ligustrum, Lucidum. Japonica, Napolense and Quihoi-Among the best of broad-leaved evergreens. Priced $\$ 1.50$ to $\$ 4.00$, according to specimen.

Chinese Arbor Vitae, 2 to $3 \mathrm{ft} \quad \ldots 1.75$

Abelia Grandiflora

Arizona Cypress, 2 to $3 \mathrm{ft}$

Boxwood, green and golden, $1 \mathrm{ft}$

Holly-leaved Ashberry, 1 to $2 \mathrm{ft}$

Mahonia Japonica, 1 to $2 \mathrm{ft}$

Cape Jessamine, 2 to $3 \mathrm{ft}$

Magnolia Grandiflora Specimen. : to 4 ft........ $\$ 1.50$ to 2.00

Red Cedar _-

Hemlock .........

Norway spruce

Irish Juniper, small

Enonymus Japonica and Variegated... 


\section{Dependable Insecticides}

Spraying has now become to be an established part of the work of all farming-cotton growing, truck gardening, fruit growing, vegetable gardening and flower gardening.

Spray! Spray! Spray!-spray for insects and for fungus diseases. I believe in spraying, for I have tried and proven it. It is just as much a necessity as fertilizing and good cultivation.

Success is dependent upon the exercise or proper judgment in making applications. Know the enemy to be destroyed; know the remedies that are most effective, and finally apply them at the proper season. Be prompt, thorough and persistent.

Direction for applying the different preparations are printed on the package.

Poisonous insecticides and liquids of any kind are not permitted in the mails, so all packages of poisons, no matter how small, must be sent by express or freight at purchaser's expense.

DRY ARSENATE OF LEAD-Does not burn the foliage, absolutely safe to use, kills every -insect that eats it, superior in every way to Paris Green, as it does not burn or scald the foliage; can be used dry as a powder or as a solution in water. Price, $1 / 2$ lb., $30 \mathrm{c} ; 1 \mathrm{lb} ., 50 \mathrm{c} ; 5$ lbs., $\$ 2.25 ; 10$ lbs., $\$ 4.00 ; 25$ lbs., $\$ 8.50$. Cannot be mailed.

CALCIUM ARSENATE (Powdered)-This is proper and most effective powder for dusting on cotton for eradicating the boll weevil. It is the poison used by the U. S. Department of Agriculture in experiments which proved that the boll weevil could be killed out at a profitable cost. 1 lb., 50c; 5 lbs., $\$ 2.00 ; 10$ lbs., $\$ 3.50 ; 25$ lbs., \$7.25. Cannot be mailed.

POWDERED OR DRY BORDO-The perfect dry Bordeaux mixture, all ready to be mixed, as you need it, with water; kept dry will last for years; full directions on every package how to use it $1 \mathrm{lb} ., 45 \mathrm{c} ; 5 \mathrm{lbs} ., \$ 1.75 ; 10 \mathrm{lbs} ., \$ 3.00$; 25 lbs., $\$ 6.25 ; 50$ lbs., $\$ 10.50 ; 100$ lbs.. $\$ 20.00$. Cannot be mailed.

PARIS GREEN-Has been on the market for many years, and is known for its effectiveness It must be used with care; one teaspoonful to one gallon of water will be safe. $1 / 4 \mathrm{lbs}$., 20c; $1 / 2$ lb., 30c; 1 lbs., 50c; 5 lbs., $\$ 2.25 ; 100$ lbs., $\$ 36.00$. Not mailable.

PYROX-Destroys insects and prevents blight all at one spraying; a combination of Bordeaux, Paris Green and Arsenate of Lead. Especially recommended for tomato blight, etc. Lb. jar, 50c; 5 lbs., \$1.75; 10 lbs., \$2.75. Not mailable.

SCALECIDE (Pratt's)-Cures and prevents San Jose scale. One of the best dormant sprays; easy to apply, not poison. By freight only. Qt., 60 c; gal., $\$ 1.50$; 5 gals., $\$ 6.50$. Not mailable.

SULFOCIDE (Pratt's)-A sure preparation for the second spraying. Prevents wormy fruit; does not burn and easy to use. Directions on each can. Pt., 45c; qt., 80c; gal., \$2.25. Not mailable.

PARADICHLOROBENZENE-Peach tree borer control. Discovered at last, a sure cure for peach tree borer. Time of application, Sept. 25 to Oct. 31. Method of application, applied to the soil around the tree, making a little trench and then covering. The fumes descend killing all the borers and other insects around the roots. Paradichlorobenzene must not be used on any trees under 5 years old, as it is very powerful and will harm young trees. No danger in handling this wonderful discovery as it is non-poisonous to man. Price, per pound, which is enough for 16 trees, $75 \mathrm{c} ; 5 \mathrm{lbs} ., \$ 3.00 ; 10 \mathrm{lbs}$., $\$ 5.00$. By parcel post; 1 lb., 85c; 5 lbs., $\$ 3.15$; 10 lbs., $\$ 5.20$.
DRY OR POWDERED LIME SULPHUR-This new preparation is taking the place of the liquid formula. Besides, it doesn't spoil. You can use as you want same, and then you also don't have to pay freight on water. Fourteen pounds Powdered Lime Sulphur will make 50 gállons of spray material. Full directions come with every package. Price, 1-lb. pkg., 35c; 5-lb. pkg., $\$ 1.50 ; 10$-lb., $\$ 2.50 ; 25-1 b ., \$ 4.50$. By parcel post, 1-llb. pkg., 50c; 5-lb. pkg., \$1.75.

SULPHO TOBACCO SOAP_Kills all insects on plants; simple and effective. By freight: $3-o z$. cake, 15c; 8-oz., 35c. Parcel post: 3-oz. cake, $20 \mathrm{c} ; 8-0 z ., 40 \mathrm{c}$.

TOBACCO DUST $\rightarrow$ For lice and other insects on all vegetable and flower plants. 1 lb., 25c: 5 lbs., $\$ 1.00$; 25 lbs., $\$ 2.00$. Post paid, 1 lb., 35c; 5 lbs., $\$ 1.15$.

BLACK LEAF 40 -A nicotine solution for destroying aphis, lice, etc., on both garden and flowering plants. A teaspoonful makes 1 quart of solution. This is one of the most effective preparations for general suckling insect. Ozbottles, 35c; 1/2-lb. tin, $\$ 1.25 ; 2-1 b$. tin, $\$ 2.50$.

BUG DEATH-Very safe, being non-poisonous; effective on all garden insects. Price, by freight Lb., 20c; 3 lbs., 45c; 5 lbs., 65c; $12 \frac{1}{2}$ lbs., $\$ 1.35$; 100 lbs., $\$ 8.50$. Parcel post: Lb., 30c; 3 lbs., $60 \mathrm{c} ; 5$ lbs., 85c; $12 \frac{1}{2}$ lbs., $\$ 1.90$.

SLUG SHOT, HAMMOND'S-Non poisonous; a splendid powder for general use. 1 lb., 20c: 5 lbs., 65c; 10 lbs., $\$ 1.25 ; 25$ lbs., $\$ 2.50 ; 100$ lbs., $\$ 9.00$. Post paid, 1 lb., 30c; 5 lbs., $80 \mathrm{c} ; 10 \mathrm{lb}$ s., $\$ 1.50$.

FISH OR WHALE OIL SOAP-Prevents and cures aphis and other troubles on plants and trees. No. 4: $1 \mathrm{lb} ., 40 \mathrm{c} ; 5 \mathrm{lbs} ., \$ 1.50$. By parcel post, 1 lb., 50c; 5 lbs., \$1.65. No. 7: With Tobacco; 1 lb., 50c. By parcel post, 1 lb., 60c.

KAYSO-Prepared casein, a spreader and adhesive for use in connection with Lime Sulphur, Bordeaux and Arsenate of Lead. Simplifies spraying; makes possible the perfect coating of every part of the tree and leaves. Remember that Kayso is not only a spreader and binder; it makes the poison stick and resistant to washing effect of rains; also saves material. Don't fail to use it with your spraying work. It is inexpensive and effective. Ask for circulars. $2-1 b$. can is sufficient for 200 gallons of spray. Price: 2 lbs., 65c; 10 lbs., $\$ 2.50 ; 50$ lbs., $\$ 10.50$; By parcel post: 2 lbs., 75c; 10-lb. bag, $\$ 2.75$.

HAMMOND'S GRAPE DUST-Keep off blight and fungus disease. $1 \mathrm{lb}$. carton, 30c; $5 \mathrm{lib}$. $\$ 1.00$. Post paid, 1 lb., 35c; 5 lbs., $\$ 1.20$. 


\section{Spray Pumps for Every Need}
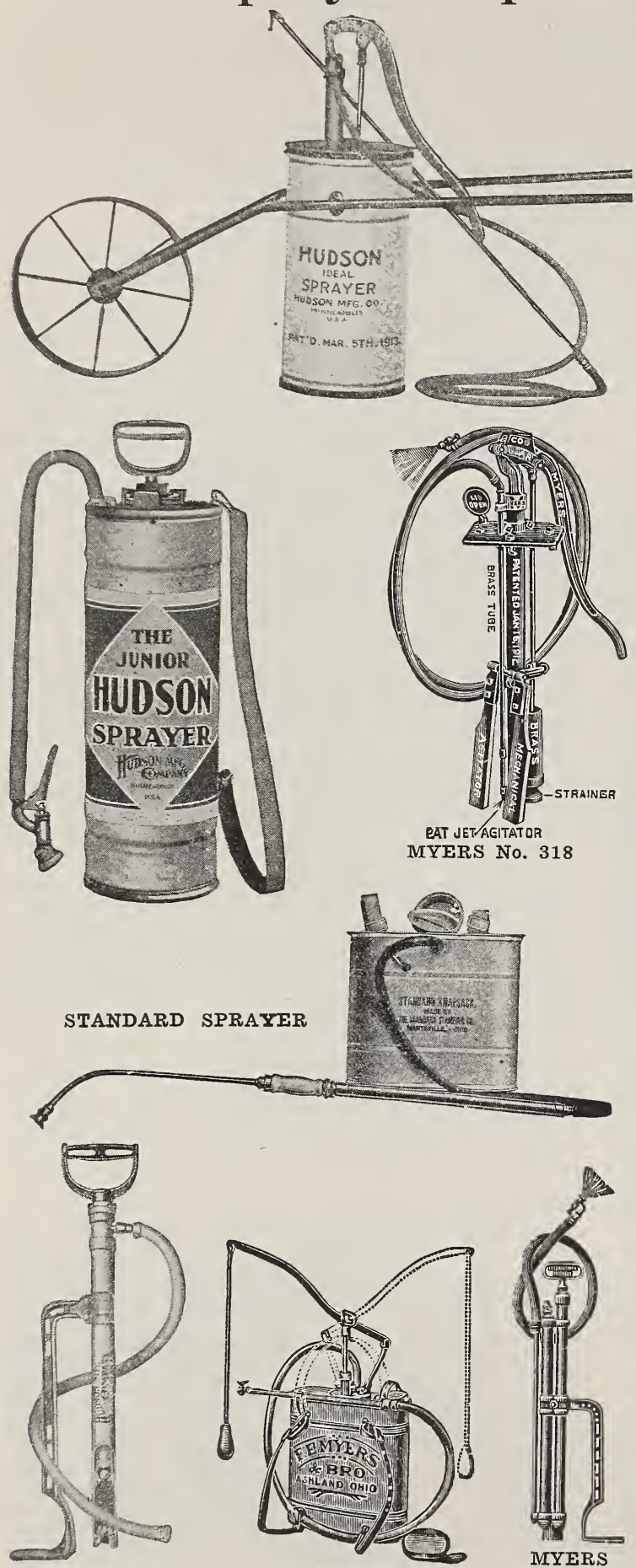

MIODOC

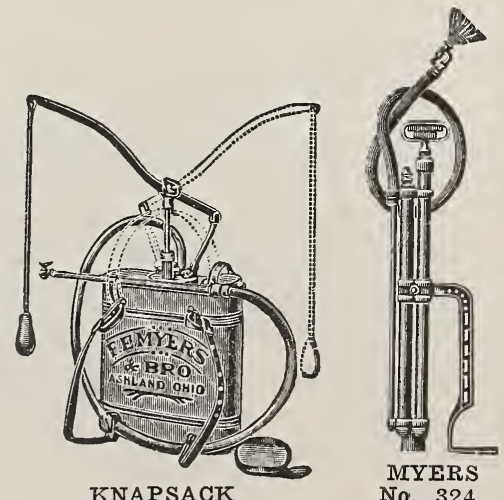

No. 324

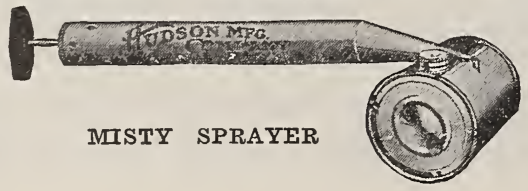

\section{IDEAL PORTABLE SPRAYER}

Equipment: Tank 15 gallons, portable, attached to an iron wheelbarrow frame with wheel; 10 feet $3 / 8$-in. pressure hose; 10 feet 2-piece pipe extension; $1 \mathrm{~T}$ shut-off cock; 1 Brandt nozzle. Weight, 65 pounds. Price, $\$ 25.00$, f. o. b. Vicksburg.

\section{MYERS No. 318 BARREL PUMP}

Has malleable iron base, fits any regular size barrel. Cylinder valves and valve seats all brass; has $15 \mathrm{ft}$. of 1/2-inch 5-ply discharge hose; mechanical agitator and Vermorel nozzle. Price complete, excepting barrel, $\$ 15.00$; with barrel, complete, $\$ 25.00$, f. o. b. Vicksburg.

\section{HUDSON PERFECTION SPRAYER}

Same sprayer as the Hudson Junior only larger, same holding four gallons of liquid. No. $110 \mathrm{G}$, galvanized tank, $\$ 6.50$; postpaid, $\$ 7.00$. No $110 \mathrm{~B}$, brass tank, $\$ 9.50$; postpaid, $\$ 10.00$.

\section{HUDSON JUNIOR}

The Hudson Junior Sprayer is made for the man who needs a high pressure compressed air sprayer smaller than the Perfection 110 . It will do any work the larger models can, for it differs from them only in capacity. Tank is galvanized and holds about $2 \frac{1}{2}$ gallons. Price $\$ 5.00$; postpaid, $\$ 5.25$.

\section{STANDARD SPRAYER}

A pump gun style spray'er, made entirely of brass, with different nozzles; you can spray large or small orchards, potatoes or garden crops and poultry houses, and will also spray whitewash satisfactory. Price, Sprayer, \$6.00; postpaid, \$6.25. Price, Sprayer with Knapsack Tank, $\$ 9.50$; postpaid, $\$ 10.00$.

\section{MODOC BUCKET PUMP}

This pump is used for a bucket spray and force pump, as well as for whitewashing. It will throw a stream 35 feet high. All solid brass, double action, bronze ball valve. Will whitewash and spray with same nozzle by simply turning the disc. Equipped with 5 -ply pressure hose. Price, $\$ 5.00$; postpaid, $\$ 5.25$.

MYERS' No. 324 BUCKET PUMP

Furnished with lever handle, which gives additional force to the stream. This is a perfect double-acting pump, easy to operate. Complete with hose and graduating vermorel nozzle. Price, $\$ 6.50$. Post paid, $\$ 7$. Eight-foot extension pipe, $\$ 1.00$ extra, f. o. b., Vicksburg.

\section{MYERS' KNAPSACK SPRAYER}

You can note from illustration that this is one of the most practical of the Knapsack sprayers. Galvanized tank. Price, $\$ 12.50$, f. o. b. Vicksburg.

\section{NEW MISTY SPRAYER}

Capacity 1 qt. One of the best sprayers made. Throws a spray as fine as mist, rendering the use of strong solutions safe on tender foliage plants, or in poultry houses. Tin, 50c; postpaid, 70c.

\section{MIDGET SPRAYER}

Same as New Misty, only smaller, holding only one pint of liquid. Tin, price, 35c; postpaid ,50c.

\section{FEENY DUST GUN}

The most practical dry powder sprayer on the market today. Each, $\$ 1.25$; postpaid, $\$ 1.40$. 


\section{Best Bacteria for Bigger Crops, Better Soil}

Every time you plant any kind of field or garden beans, peas, clover, peanuts, vetch or alfalfa, inoculate the seed with these cultures of nitrogen. Unless your soil is unfavorable, having the proper bacteria on your seed often makes an increase of 50 to 100 per cent in the crop yield, an even stand, and great numbers of nodules on roots which deposit in your soil nitrogen fertilizer (nitrates) worth $\$ 20$ to $\$ 30$ an ac

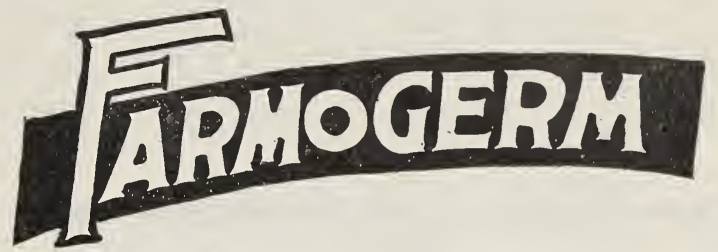
other crops grown on the land afterwards.

\section{TWO KINDS-INEXPENSIVE-EASY TO USE}

\section{HUVOGERM}

Not only is it important that you inoculate your seed, but it is just as important that you use a thoroughly reliable inoculant. Cultures are put up in two forms-either on jelly in bottles, or on soil in cans, and of the several brands on the market we handle the best of each kind, both reasonably priced and prepared for us in laboratories that specialize on preparing the biggest result-producing bacteria. You can absolutely depend upon them. Pour on the seed and plant in usual way-directions on each container.

When you order, please state variety of seed you wish to treat. We have always fresh stock for: Alfalfa, Crimson, Sweet, White, Alsike, Hubam, Bur, Lespedeza, Japan and other clovers; Soy, Velvet, Lima and all beans; Cow Peas, Sweet Peas, Beggarweed, Sesbania, Peanuts, Vetch, etc.

FARMOGERM, in bottles, patented ventilating stopper, pure bacteria for each variety of seed. Prices, postpaid: 12 -acre size, $\$ 9.00 ; 3-\mathrm{A}, \$ 2.50 ; 1-\mathrm{A}, \$ 1.00$. A special garden (1/4 acre) size that will inoculate $15 \mathrm{lbs}$., peas, beans, or sweet peas, 50c.

HUMOGERM, on finely pulverized humus, in cans, sold on bushel basis. Prices, postpaid: $21 / 2$ bu. size, $\$ 2.25 ; 1$ bu., $\$ 1.00 ; 1 / 2$ bu., $60 \mathrm{c} ; 1 / 4$ bu., 35c. Special garden size that will inoculate 15 lbs. peas, beans or sweet peas, $25 \mathrm{c}$.

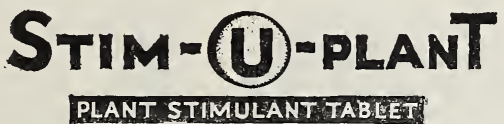

Use it and you will have the largest crops of fruit and vegetables, and an abundance of the largest and sweetest-scented flowers of intense and vivid colors. It is rich in plant food, containing 11 per cent Nitrogen, 12 per cent Phosphoric Acid and 15 per cent Potash, odorless and clean. Compare this analysis with that of other fertilizers.

Not to be thrown broadcast, but put at feeder roots of individual plants, trees, shrubs, etc.; there is no waste, you feed the plants that need it. Increases production, heightens color, improves quality. Simply insert a tablet in the soil near each plant ( $1 \mathrm{ft}$. apart if in rows) once or twice during season. Or, dissolving four tablets per gallon of water is less trouble and gives better results than the objectionable manure water. A proven success with rose growers, nurserymen, landscape gardeners, strawberry growers and gardeners. Complete directions with every package. Price, postpaid: 30 tablets, $25 \mathrm{c} ; 100$ size, $75 \mathrm{c} ; 1,000$ tablets, in bucket, $\$ 3.50$.

ACID PHOSPHATE - Available phosphoric acid, 16 per cent. It gives excellent results on nearly all crops, but is especially recommended for use on grains and grasses. Apply at the rate of 400 to 600 pounds to the acre, either in drills or broadcast. If broadcasted, it should be harrowed in at the time of applying so as to incorporate it well with the soil. $100 \mathrm{lbs}$., $\$ 2.25$, f. o. b. Vicksburg.

TRUCK GUANO-For all garden crops, beans, peas, cabbage, tomatoes, etc. Analysis: Phosphoric acid, 8 per cent; nitrogen, 4 per cent; potash, 3 per cent. 25 lbs., $\$ 1.25 ; 50 \mathrm{lbs}$., $\$ 2.00$; 100 lbs., $\$ 3.50$, f. o. b., Vicksburg

\section{SHEEP MANURE}

The Best and Safest Fertilizer for everything that grows. A weedless, concentrated manure that puts life a n d fertility into your soil. N'o mattier wh a t plants

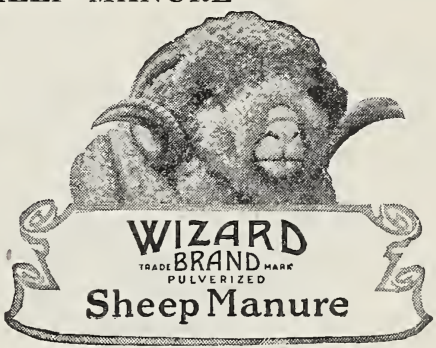
you grow, you need manure to secure the best results. Wizard is far superior to chemical stimulants and stable manure. It is a real plant food that has a lasting beneficial effect on the soil. Promotes thick velvety green lawns, a wealth of vivid colored flowers in your garden and vigorous growing shrubbery. In the vegetable garden it produces early crops of crisp tender vegetables. A highly profitable fertilizer for the florist, vegetable grower and home gardener. Prices: 5 lbs., 25c; 25 lbs., $\$ 1.00 ; 100$ lbs., $\$ 2.50$, f. o. b., Vicksburg.

PURE BONE MEAL-Invaluable for top dressing lawns. Nothing is better for fertilizing young fruit trees, grape vines, roses, etc. 4 lbs., 25c; 25 lbs., $\$ 1.25 ; 50$ lbs., $\$ 2.25$; 100 lbs., $\$ 4.00$, f. o. b., Vicksburg

NITRATE OF SODA-Nitrate of Soda is power. It can be used on all field and garden crops, either mixed with the soil or applied aftercrops are up and growing. It requires about $150 \mathrm{lbs}$. of Nitrate of Soda to the acre. Application of Nitrate of Soda not only increases the yield, but also makes crops mature earlier, and in case of drought the plants will stand the dry spell wonderfully good. 4 lbs., $25 \mathrm{c} ; 25$ lbs., $\$ 1.25$; 100 lbs., $\$ 4.50$, f. o. b., Vicksburg 


\section{Seed Sowers, Garden Plows, Hanging Baskets}

For those who desire to do their gardening and farming in the modern and most economical way, we suggest that they avail themselves or some of the latest approved equipment that we are offering at such reasonable prices. The farmer or gardener today who does not advance with the times will experience the misfortune of having his profits cut by continuing to use the oldfashioned and out-of-date machinery.

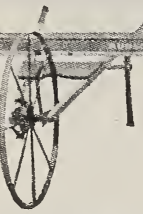

\section{THOMPSON'S WHEELBARROW SEED SOWER}

The Thompson Wheelbarrow Seeder gives a perfect uniformity and eveness of putting down the seed, more so than any other style we know of. We handle only the No. 2 Seeder, which is superior to the No. 1, from the fact that it sows in addition to the heavier seeds, like Timothy, Alfalfa and Clover Seeds, all Grass seeds and Lespadeza. Price: No. 2, 14-ft. Thompson Wheelbarrow Seeder, each, $\$ 12.50$, F. O. B. Vicksburg.

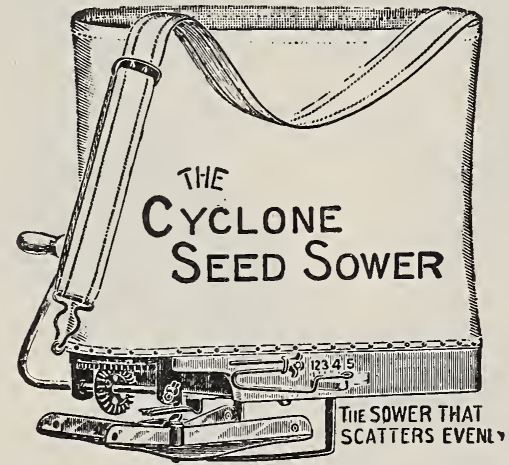

CYCLONE SEED SOWER

Will sow timothy, clover, oats, rye, wheat, millet, grass seeds, peas, sorghum, etc. Distributes evenly, works perfectly; has an agitator feed plate, which insures a uniform flow of seed. Price, each, $\$ 2.25$; postpaid, $\$ 2.40$.

\section{THE LIGHTNING HORN SEEDER}

A splendid little tool, simple and easy to operate. Will sow any fine grain like clover, lespedza, timothy, alfalfa and grasses. Holding the tube downward wind won't blow seed away. We know this seeder to be good. Price, $\$ 1.00$; postpaid, $\$ 1.10$.

\section{WIRE HANGING BASKETS}

8-inch, each...\$0.25 12-inch, each.....\$0.40 10-inch, each.... .35 Postpaid, 20cents extra

\section{GREEN SHEET MOSS}

For wire flower baskets. Lb., 60c; by parcel post, 70c.

\section{REDDICK MOLE TRAP}

The Reddick Mole Trap is the best and easiest handled of all traps of this kind on the market. Price, each, $\$ 1.25$; postpaid, $\$ 1.40$.

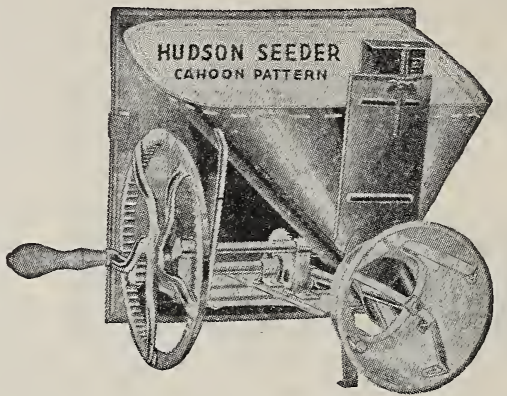

\section{CAHOON BROADCAST SEEDER}

One of the best seeders manufactured, and sows all kinds of grain, clover seeds, etc., rapidly and evenly. Price, each, $\$ 4.50$; postpaid, $\$ 4.75$.

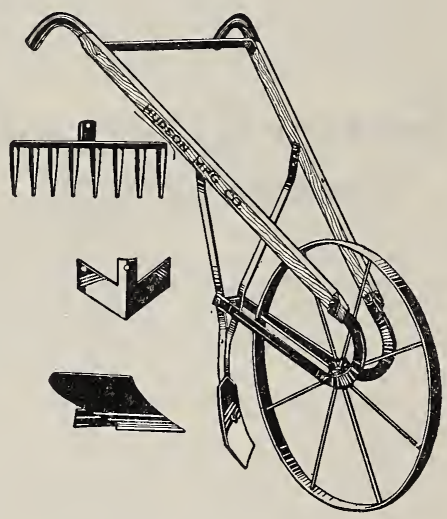

HAND GARDEN PLOWS

The most inexperienced and ignorant laborer on earth can handle this tool with entire success. All kinds of work can be done with this plow and combination of tools; plowing and breaking of the ground in spring and harrowing cultivating. Price, each, $\$ 3.75$, f. o. b., Vicksburg.

\section{SAVO FLOWER AND PLANT BOX All Year Round}

Self-watering and self-irrigating. For winter and summer use. Fill with water only once a week. Cannot overwater plants. Air goes direct to the roots. Prices, f. o. b. Vicksburg: Model

Price A- 8 in. high, $91 / 2$ in wide, 23 in long $\$ 3.50$ B- 8 in. high, $91 / 2$ in. wide, 29 in long 4.00 C- 8 in. high, $91 / 2$ in. wide, 35 in. long 4.50 $\mathrm{D}-8 \mathrm{in}$. high, $91 / 2$ in. wide, $41 \mathrm{in}$. long 5.00

\section{SEGEMENT HAND CORN PLANTER}

This is the best one-hand corn planter on the market and very satisfactory. $\$ 2.00$ each. Postpaid, each $\$ 2.25$. 


\section{CANARY BIRDS, CAGES, GOLD FISH and SUPPLIES}

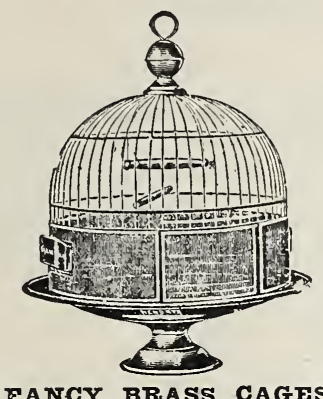

FANCY BRASS CAGES

These are all handsome fancy style, every one an ornament.

No. 8000 Brass Bungalow Square Cage, each---_\$14.00 No. 8020 Brass Bungalow Square Cage, each_-_- 14.00

No. 274 Brass Round Cage, each__-____-_-- 5.50

No. 275 Brass Round Cage, each

No. 276 Brass Round Cage, each

If wanted by parcel post, add 35c each for packing and postage.

\section{OBTONG BRASS CANARY CAGFS}

No. 5004 Brass Cage, $95 \frac{8}{8} \times 6 \frac{1}{2}$-in., each-------- $\$ 3.70$ No. 5006 Brass Cage, $103 / 8 \times 7 \frac{1}{8}$-in., each-------- 4.45 No. 5008 Brass Cage, $103 \% 4 \times 7 \%$-in., each-------- 5.30
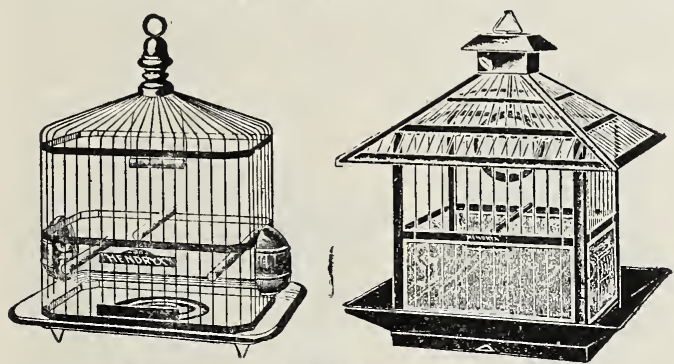

JAPANNFD CANARY BIRD CAGES

No. $165-$ New Style Japanned Cage, $9 \frac{1}{2} \times 6 \frac{1}{2}$ inches, each -

No. 165 DB-New Style Japanned Cage, $91 / 2 \times 6 \frac{1 / 2}{2}$

inches, each _. 3.00

No. 166--New Style Japanned Cage, 10x7 inches, each $16 \overline{6}$ DB-New Style Japanned Cage, $10 \times 7$ inches, each

No. 167. DB-New Style Japanned Cage, $11 \times 7 \frac{1}{2}$

inches, each 4.00

No. 167--New Style Japanned Cage, $12 \times 8$ inches,

No. $168-\mathrm{New}$ Style Japanned Cage, $18 \times 8$ inches, 3.60

each -

No. 168 DB-New Style Japanned Cage, $12 \times \overline{8}$

inches, each _-

No. 6-Round, 10-in. diameter, $16 \%$ in. high

No. $61 / 2$-Round, 11 in. diameter, $17 \frac{1}{2}$ in. high -5.50

No. $7-$ Round, 12-in. diameter, 18 in. high

If cages are wanted by parcel post, add $35 \mathrm{c}$ each for packing and postage.

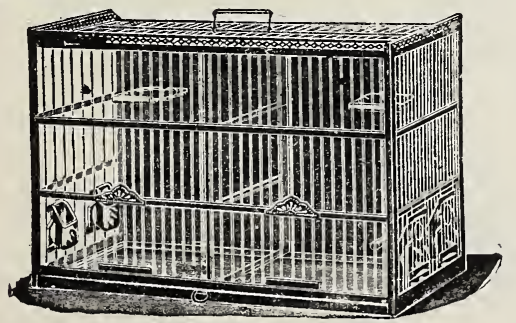

BREIDING CAGFS

No, $86 \mathrm{~S}$-Metal Breeding Cage, $17 \times 8 \times 13$ in.--- $\$ 5.80$

No. 86 - Metal Breeding Cage, $20 \times 10 \times 14$ in.--- 7.40

$\begin{array}{lll}\text { No. } 86 & \text { - Metal Breeding Cage, } 20 \times 10 \times 14 \text { in.---- } 7.40 \\ \text { No. } 87 \text { - Metal Breeding Cage, } 22 \times 11 \times 15 \text { in.--- } 8.10\end{array}$

No. 88 -Metal Breeding Cage, $24 \times 12 \times 16$ in.--- 10.00

If wanted by parcel post, add $35 \mathrm{c}$ for packing and postage.
Our birds are the genuine Hartz Mountain strain. Each one is thoroughly tested before shipping to be sure it is a No. 1 guaranteed singer. Price $\$ 10.00$ each

St. Andreasburg Rollers, highly trained. Price $\$ 10.00$ each

Female canaries for breeding, $\$ 2.50$ each, f. o. b. Vicksburg.

\section{MISCEIIANEOUS BIRD SUPPIIES}

Bird Cage Seed Cups, opal or glass, 20c; postpaid $\$ .25$

Bird Cage Bath Cups, each-------20c; postpaid .30

Bird Cage Brackets, 12-in., each--- 35c; postpaid .45

Bird Cage Brass Springs, each---_20c; postpaid .25

Bird Cage Chain with springs, each $30 \mathrm{c}$; postpaid .35

Bird Cage Nests, wire, each-_.-- 10c; postpaid $\mathbf{. 1 5}$

\section{BIRD FOODS, ETC}

Phil. Bird Manna, each_-_-__-15c; postpaid $\$ .20$

Phil. Mixed Canary Seed, pt. box -20c; postpaid .30

Phil. Silver Gravel, pt. box

Phil. Red Gravel, pt. box---- $-15 \mathrm{c}$; postpaid .25

Phil. Bird Bitters, bottle

Phil. Bird Mite Exterminator, box $-25 \mathrm{c}$; postpaid .30

Phil. Bird Moulting Pepper, box_---25c; postpaid .30

Phil. Bird Nestling Food, box_----25c; postpaid .30

Phil. Bird Nestling Hair, box----10c; postpaid .15

Canary Seed, plain, $1 \mathrm{lb}$

Canary Seed, mixed, 1 lb.-------15c; postpaid .25

Hemp Seed, 1 lb...-

Millet Seed, 1 lb.-- 20

Rape Seed, 1 lb.- 30

Sunflower Seed, 1 lb..-.

Cuttle Fish Bone, each

Cuttle Fish Bone, with holder, each_15c; postpaid .20

\section{GOID FISH}

Anerican Gold Fish-The well known bright scarlet and gold color. Small, each $15 \mathrm{c}$; medium, each $25 \mathrm{c}$ large, each 50c; tin bucket for shipping, extra, $35 \mathrm{c}$ each.

\section{GOID IISH BOWLS}

Glass Bowls-Made of clear glass, in following sizes: 2-quart, each - 4-quart, each 2-gallon, each 3 -gallon, each -

These cannot be sent by parcel post, they must go by freight or express, at buyer's expense.

\section{FISH FOOD}

Wafer Fish Food, pkg., postpaid

\section{AOUARIUM CASTIES}

Assorted styles priced from $35 \mathrm{c}$ to $75 \mathrm{c}$ each.

\section{GIOVER'S IMPERIAI DOG MEDICINIS}

Glover's Mange Medicine, per bottle-_-_-_-_-_-_\$ .65

Glover's Distemper Medicine, per bottle-_-_-- 1.25

Glover's Vermifuge, for expelling worms in dogs.

per bottle

$\begin{array}{ll}\text { per bottle } & .65 \\ \text { Glover's Worm Capsules, per box }\end{array}$

Glover's Tape Worm Capsules, per box-_-_-_-_. .65

Glover's Condition Pills, per box_-_-_-_-_-_.-. 65

Glover's Canker Wash, per bottle__._-_._-_-_. .65

Glover's Eye Lotion, per bottle_-_-_-_-_-_-_. .65

Glover's Blood Purifier, per bottle_-_- .65

Glover's Diarrhoea-Medicine, per bottle_______-_ .65

Glover's Fit Medicine, per bottle___-_-_-_-_.- .65

Glover's Tonic, per bottle_____-___-_-_-_- .65

Glover's Cough Mixture, per bottle_-_-_-_-_-_-- .65

Glover's Sore Foot Medicine, per bottle_-_-_-_-_- .65

Glover's Black Tongue Medicine, per bottle__-_- .65

Glover's Compound Sulphur Tablets, per box_--- .65

Glover's Digestive Pills, per box_-_-_-_-_-_-- .65

Glover's Liniment, for rheumatism, per bottle-_-- .65

Glover's Liver Pills, per box_-_-_-_-_-_-_- .65

Glover's Kennel and Stable Soap, per cake_._-_. .30

If wanted by parcel post add 10 cents.

BFNNETT'S MILK BONE DOG BISCUIT

A superior preparation. Keeps dogs in good condition. Ask for circulars. Per box 40c; postpaid, 50c.

BENNETT'S MIIK BONE PUPPY BISCUIT

Especially prepared for puppies. They thrive and grow fat on M. B. Biscnits. Per box, $40 \mathrm{c}$; postpaid $50 \mathrm{e}$. 


\section{POULTRY REMEDIES}

\section{CONKEY'S POULTRY REMEDIES}

Conkey's Gape Remedy _-_-_-\$.25; postpaid_.-\$.30

Conkey's Gape Remedy ------ .50; postpaid__- .55

Conkey's Head Lice Ointment_- .10; postpaid_-- .15

Conkey's Head Lice Ointment_- .25; postpaid_-- .30

Conkey's Scaly Leg Remedy_-- .25; postpaid_-- .30

Conkey's Poultry Worm Powder .25; postpaid_-- .30

Conkey's Poultry Laxative_-_- .25; postpaid_-- .30

Conkey's Lice Fix Salve_----- .50; postpaid_-- .55

Conker's Laying Tonic, small_- .25; postpaid_-- .30

Conkey's Laying Tonic, large_- .50; postpaid_-- .60

Conkey's Lice Power_--_----- .35; postpaid__- .45

Conkey's Lice Power _-_-_-- .75; postpaid_-- .85

Conkey's Canker Special____ . .50; postpaid_-- $.55 \mathrm{c}$

Conkey's Noxicide, 1-qt._._-_. .50 ; cannot be mailed

Conkey's Noxicide, 1-qt._-_- .80; cannot be mailed

Conkey's Noxicide, 1-gal._-_--_ 2.00; cannot be mailed

Conkey's Roup Powder, small_- .30; postpaid_-- .35

Conkey's Roup Powder, medium .60; postpaid_-- .65

Conkey's Cholera Cure, small_- .25; postpaid_-- .30

Conkey's Cholera Cure, large_- .50; postpaid_-- .55

Conkey's White Diarrhea Cure,

Conkey's White Diarrhea Cure,

large

Conkey's Chicken Pox Rem., lge.
.30 postpaid

$.60 ;$ postpaid .25 ; postpaid $.50 ;$ postpaid
Conker's Limber Neck Remedy .50; postpaid_-- .55

Conkey's Noxicide, 2-qt_-_---- 1.30; cannot be mailed

Conkey's Roup Powder, large_- 1.20; postpaid_-- 1.25

Conkey's Chicken Pox Red, small

\section{PIPENE}

One application cures the worst case of Roupe. Pipene is injected in the nostrils from inside the mouth and one treatment effects a sure cure. Price, $60 \mathrm{c}$; parcel post, $65 \mathrm{c}$.

\section{DIARRENE}

Prevents and cures White Diarrhoea in baby chicks; is absolutely a sure and safe remedy. Price, 60c; by parcel post, $65 \mathrm{c}$.

\section{COLDENE}

For colds in chickens; put up in tablet form, abso. lutely guaranteed. Price, $60 \mathrm{c}$ a box. By parcel post. 65 cents.

\section{LICENE}

Licene will destroy every louse and "nit", on your chickens, usually keeping them free from lice for six months. Per tube, 60c; by parcel post, 5c extra.

\section{LEE'S POULTRY REMEDIES}

Not past $3 r d$ zone

Lee's Egg Maker, 2-1b. box _- $\$ .40$; postpaid_-- $\$ .50$

Lee's Egg Maker, 5-lb. box-- .90; postpaid_-- 1.00

Lee's Lice Powder, small size_- .25; postpaid_-- .35

Lee's Lice Powder, large size_- .50; postpaid_-- .60

Lee's Liquid Lice Killer, 1-qt.- .60; cannot be mailed

Lee's Liquid Lice Killer, 2-qt. 90; cannot be mailed

Lee's Liquid Lice Killer, 1 gal 1.50; cannot be mailed

Lee's Egg-O-Hatch _- -

Lee's Egg-O-Latum

\section{LEE'S GERMOZONE}

Don-Sung (Chinese for egg laying) is given in the feed and doesn't force or burst the hen in any way, in fact, it makes her healthier. It is a new scientific discovery for hens, that merely stimulates the egg organs, making them strong and vigorous and as a result they lay regularly in any season. Try a box, we guarantee it. Ask for circulars. Price per box ,50c; large size, $\$ 1.00 ;$ postage $5 \mathrm{c}$ extra.

\section{AVICOL}

A safe and effective remedy in tablet form for White Diarrhea, Cholera, etc., in small and large grown fowls. Avicol is now being used by thousands of successful poultry raisers the world over. Write for circulars. Price, 25c, 50c and $\$ 1.00$ per plig. Postage 5c extra.

\section{TALCIMIZED SODIUM FLOURIDE} Kills Poultry Lice

Talcimized Sodium Flouride is made especially for poultry and carries the Government's directions for ap. plying. It is safe, easy to use, inexpensive and absolutely does the work quickly and effectively. Price, 35c (enough to treat 50 chickens). Postpaid, 40c.

\section{CARBOLA}

The disinfectant that paints. Carbola is infinitely superior to lime, which loses what slight disinfectant qualities it ever had by slacking when exposed to the air. It may be used on either stone, brick, wood, metal or cement, and can be put on over a whitewashed or painted surface. Can be applied with either sprayer or brush. Price, 5-lb. package, 75c; postpaid, 90c; 10-1b. pkg., $\$ 1.25$; postpaid, $\$ 1.50$; postpaid not past 3rd zone.

\section{ZENOLEUM}

A scientific compound preparation. The various kinds are used for live stock and poultry to prevent lice and mites as well as general use about the farm, barn and the house. Zenoleum is used and recommended by fifty agricultural colleges and experiment stations. Zenoleum Dip and Disinfectant, 8-oz. can, $35 \mathrm{c} ; 1$ qt. $75 \mathrm{c} ; 2$ rts., $\$ 1.25 ; 1$ gal., $\$ 2.00$. Cannot be mailed.

\section{COW EASE}

Cow Ease keeps off flies; gives cows a chance to feed in peace; repellant to lice; good for barn or cattle itch. does not gum the hair; increases the flow of milk; good for spraying hogs-in fact, Cow Ease is one of the best preparations of its kind on the market. Qt., $60 \mathrm{c} ; 1 / 2$ zal., $90 \mathrm{e}$; gal., $\$ 1.25$.
Liquid, 4-oz. bottle, $40 \mathrm{c}$; $12-\mathrm{oz}$. bottle, $75 \mathrm{c}$, not mailable. Tablets, small size, $65 \mathrm{c}$; large size, $\$ 1.25$ per box. Postpaid, $70 \mathrm{c}$ and $\$ 1.30$.

\section{SAL VET}

Sal Vet-Destroys worms in Hogs. Sheep, Horses and Cattle. Simply put Sal Vet in the animals' troughs, or give it to them in their feed. Send for circulars.

$5-1 b$. package _-_______ \$.60; postpaid__-\$.75

15-1b. package _-_-_-_-_-- 1.50; postpaid_-- 1.85

50-1b. package 100-1b. package _..... 6.75 ; cannot be mailed

\section{B-K BACILI KIL}

\section{Disinfectant, Deodorant, Cleanser}

Note these remarkable qualities:

POWERFUL-By Government method of test B-K has over ten times greater germ-killing strength than carbolic acid. Much stronger than coal tar disinfectants -much safer.

SAFE-B-K contains no poison, acid nor oil.

CLEAN-B-K is colorless, leaves no stain on floors, walls or utensils. Does not soil animal's hair.

DEODORANT-B-K destroys foul odors-leaves no odor of itself.

CHEAP TO USE-B-K is so strong that much water is used in diluting. One gal. B-K makes 200 to 500 gals. of dilution ready for use according to the pur. pose.

\section{EVERY USE OF B-K SAVES WORK USE FOR}

Contagious Abortion
Retained After-birth
Barrenness
Calf Scours-Bloat
Poultry Diseases
Little Pig Diseases
Barn Disinfecting

Sterilizing
Milk Cans, Bottles
Separators
Milking Machines
Deodorizing
Cleaning Show Animals
Home Sanitation

Foul Brood in Bees

Price 1 qt. bottle, $\$ 1.25 ; 1$ gal. jug, $\$ 3.00 ; 5$ gals., $\$ 12.50$, f. o. b. Vicksburg. 


\section{Poultry Feeders and Founts}

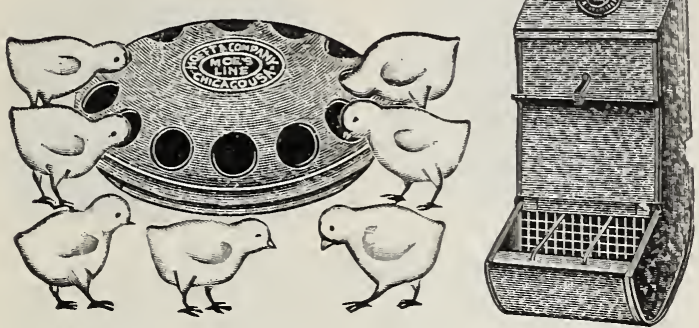

MOE'S ROUND BABY CHICK FEEDER

The most convenient feeder on the market. Can also be used for water. Two sizes. No. 11, 6 inches with 6 boles, and No. 12, 81/ inches with 12 holes. Price: No. 11, 20c; by express; $30 \mathrm{c}$, by parcel post. No. 12, $30 \mathrm{c}$, by express; 40c, by parcel post.

\section{MOE'S DRY MASH HOPPERS}

A strictly high quality hopper, properly designed. The curved bottom keeps the feed in easy reach, and the taper shape of the hopper prevents the feed from clog. ging. Height 19 inches. No. 35, width $81 / 2$ inches, each $\$ 1.50$; postpaid, $\$ 1.75$. No. 36 , width 12 inches, each $\$ 2.00$; postpaid, $\$ 2.35$. No. 13 , width 18 inches, each $\$ 2.40$; postpaid $\$ 2.80$.
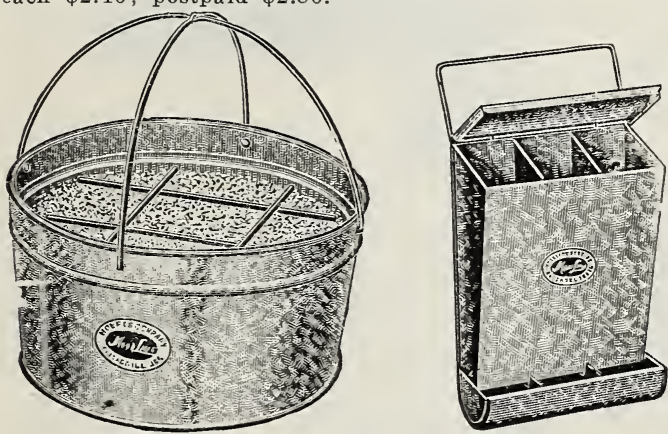

MOE'S ROUND MASH HOPPFR

A good, economical Dry Mash Feeder, made of heavy galvanized iron with a capacity of 8 quarts. Can ve fastened with a cord or wire to the ceiling of the poultry house and thus hung up out of the litter at any height desired. Has a rolled-in edge, and wire grid which rests on the feed and prevents the birds from wasting it. The top wire bales also prevent the chickens from getting in the hopper. Price, each $75 \mathrm{c}$; postpaid, $95 \mathrm{c}$.

\section{GRIT AND SHELL BOXES}

Grit, shell and charcoal have now become a recog. nized sontial part of the diet, insuring healthr fowls, and it cannot be more economically supplied than in one of these triple compartment boxes.

No. $45-2$ compts., for chicks.$--\$ .40$; postpaid $\$ .50$ No. $9-3$ compats., for hens No. $90-4$ compartments______- 1.25 ; postpaid 1.45

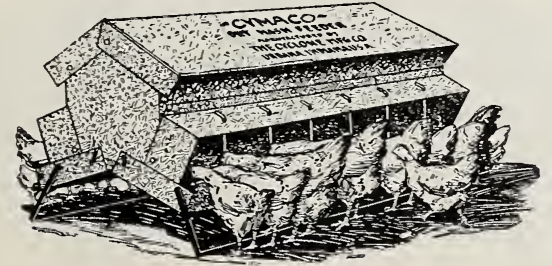

CYMACO DRY MASF FELDER

This is a new Mash Feeder, and one with number of special features, as follows: Stands on legs, san be placed in center of pen, feeds on both sides, flow adjustable, troughs shedded, equipped with agitators. Made in two sizes. No. 12, 12 inches long, $\$ 2.25$; No. 24, 24 inches long, $\$ 3.75$ each, f. o. b. Vicksburg.

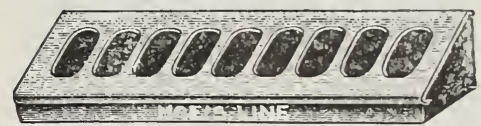

MOE'S SINGLE FEEDING TROUGH

For chicks and growing stock. Accurately stamped with dies. No rough edges, and can be hung on the wall. Sliding top. No. 55, length 12 inches, each $35 \mathrm{c}$; No. 56, length 18 inches, each $40 \mathrm{c}$; No. 57, length 24 inches, each 55c. Postpaid, add 10c each.

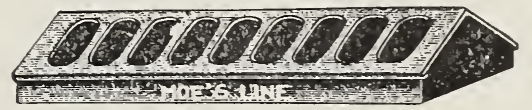

\section{MOE'S DOUBLE FEEDING TROUGH}

Double trough with sliding top, easily filled and cleaned. Accurately stamped with dies. No rough edges. No. 58, length 12 inches, each $45 \mathrm{c}$; No. 59, length 18 inches, each $60 \mathrm{c}$; No. 60, length 24 inches, each $70 \mathrm{c}$. Postpaid, add $10 \mathrm{c}$ each.

\section{MOE'S TOP FILL FOUNTAIN}

Fills from the top. Dead air space keeps water cool in summer and from freezing in winter. Now made with square pan, which does away with spilling when hung up. Can be used for two pens at the same time. Manufactured in 3 sizes.

Yo. 1-1-gallon capacity - $-\$ 1.75$

No. 2-2-gallon capacity No. 4-4-gallon capacity _-

By parcel post, 25c each extra.
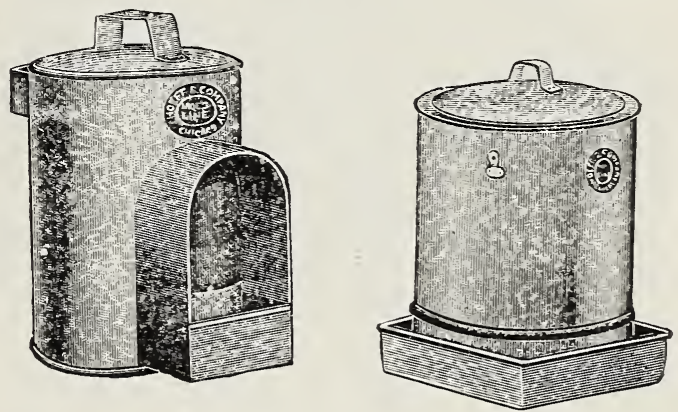

WALL OR HUB FOUNTAIN

The covered outlet keeps out dust and dirt, and s removable plate prevents any floating rubbish from being drawn into the reservoir.

To, $97-2$-qt. capacity, each_-__ $\$ .90$; postpaid $\$ 1.05$ No. 98-1-gal. capacity, each---- 1.10 ; postpaid 1.25 No. 99-2-gal. capacity, each---- 1.40 ; postpaid 1.60
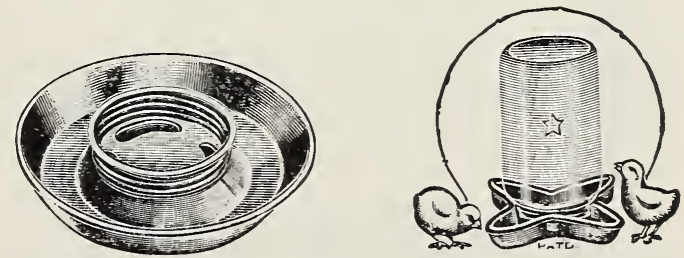

\section{ECONOMY FOUNT OR FEEDER}

No parts to come unsoldered. Leaking impossible. IVill fit pint, quart or half-gallon Mason jar. Convenient, cheap and sanitary. One size only. Price of holder without jar; each, 30c. By parcel post, each, $40 \mathrm{c}$.

\section{STAR JAR FOUNTAIN AND FEEDER}

No parts to come unsoldered. Leaking impossible. Will fit pint, quart or half-gallon Mason jar. Convenient, cheap and sanitary. One size only. No. 32, each, $15 \mathrm{c} ; 6$ for $75 \mathrm{c}$. Postpaid, each, $20 \mathrm{c} ; 6$ for $90 \mathrm{c}$. 


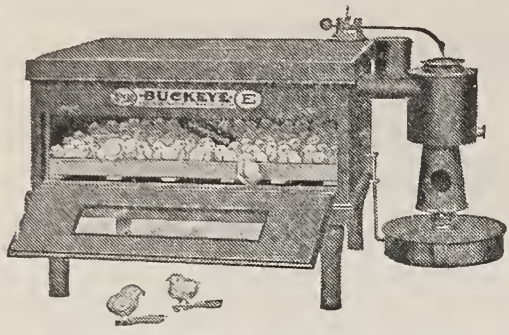

BUCKEYE INCUBATORS

Buckeye No. 14, Style E, 65-egg Incubator-_-_ $\$ 16.50$ Buckeye No. 16, Style E, 110-egg Incubator---- 27.50 Buckeye No. 17, Style E, 210-egg Incubator Buckeye No. 1, Standard 110-egg Incubator Buckeye No. 2, Standard 175-egg Incubator Buckeye No. 3, Standard 250-egg Incubator-_-- 57.75 Buckeye No. 4, Standard 350-egg Incubator_._- 68.00

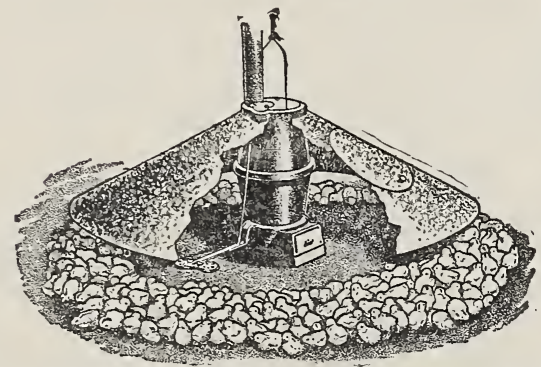

\section{BUCKEYE STANDARD COLONY STOVE} BROODER

The most remarkable coal-burning brooder ever inrented. It is self-feeding, self-regulating, simple, safe and everlasting. Cuts the cost of equipment and cost of operation to less than half. Reduces the time and labor to less than a fourth. Simple as a kitchen range. Broods from 100 to 1000 chicks. Write for special circulars. No. 18 - Capacity 500 chicks, price_-_No. 19 -Capacity 1000 chicks, price-_-

\section{BUCKEYE BLUE FLAME BROODER}

In the construction of this Brooder valves of every character have been eliminated. Experience proved them to be dangerous and impractical. The lighting process is exactly like lighting an ordinary house lamp. No priming needed and no special education required to operate it. Produces greater volume of heat with smaller consumption of oil. Will not use more than gallon of oil in 24 hours. Large channels guard against stopping oil supply and assure continuous heat. In three sizes :

No. 27-Capacity up to 200 chicks, diam. 34 in.-- $\$ 17.50$ No. 28-Capacity up to 350 chicks, diam. 42 in.-- 20.00 No. 29-Capacity up to 500 chicks, diam. 52 in.-- 22.50 All above prices on incubators and brooders, F. O. B. Vickshurg.
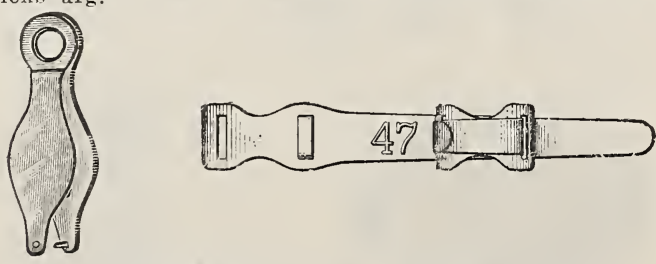

\section{CHAMPION LEG BANDS}

This aluminum band is made in one riece, adjustable to fit any fowl. Held by double lock; it is impossible for them to lose off. Numbered from 1 to 400 . Price, doz., $15 \mathrm{c}$; 25 for $25 \mathrm{c}$; 100 for $75 \mathrm{c}$, postpaid.

\section{COLORED SPIRAL LEG BANDS}

Made in many different colors-red, green, blue, yellow, pink, white, etc. Slip on just like a key ring; no tools required. Will not come off; fowls cannot lose or remove them. Made in all sizes. State for what breed you want the bands. 12 for $20 \mathrm{c}$; postpaid, $25 \mathrm{c} ; 25$ for $35 \mathrm{c}$; postpaid, $40 \mathrm{c} ; 50$ for $65 \mathrm{c}$; postpaid, $70 \mathrm{c} ; 100$ for $\$ 1.25$; postpaid, $\$ 1.35$.

COMPLETE BUCKEYE INCUBATOR AND BRC
POULTRY PUNCHES

Pettey Poultry Punch-Cuts clean hole with oase. Price, 30c, postpaid.
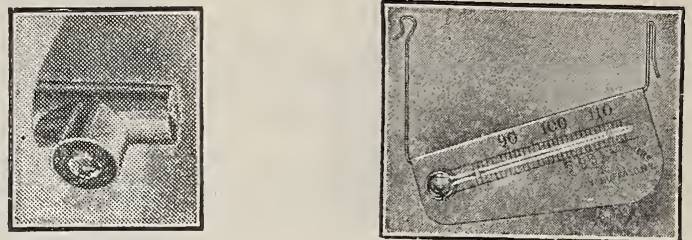

X-RAY EGG TESTER

Designed for use on an ordinary hand lamp and fits over any style burner with a diameter approximately that of the tester. Each, $30 \mathrm{c}$; postpaid, $40 \mathrm{c}$.

\section{BUCKEYE INCUBATOR AND BROODER EXTRAS}

Buckeye Inc. Thermometers, each, $\$ 1.00$; postpaid $\$ 1.10$ Buckeye Inc. Lamp Bowls, each_-- 1.00 ; postpaid 1.15 Buckeye Inc. Lamp Burners, $75 \mathrm{c}$ and 1.00 ; postage extra Buckeye Inc. Lamp Chimney, each .50; postpaid 60 Buckeye Inc. Ad. Rod \& Set Screws .50; postpaid .60 Buckeye Egg Testers, each__-_. .50 ; postpaid .60 Buckeye Brooder Thermometer, ea. 1.25 ; postpaid 1.35 Buckeye Brooder Wafers, each_-_ .50; postpaid .55

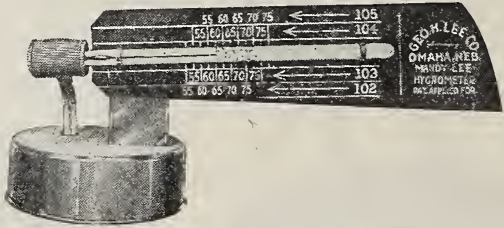

MANDY LEE HYGROMETER

Registers accurately the percentage of moisture in the egr chamber, and directions that go with it show absolutely what percentage of moisture is needed dur. ing each day of incubation and how the desired amount may be maintained, regardless of the humidity of the outer air. Can be used in any incubator. Price of the Mandy Lee Hygrometer, \$2.00; postpaid, \$2.10. Extra wicks, $10 \mathrm{c}$ each; 3 for $25 \mathrm{c}$.

IMPROVED AUTOMATIC CHICK GREASER

Saves the chicks from vermin. The chicken its own doctor. Will grease 100 chicks in a few minutes. Kills mites, fleas, lice and red bugs. The chicken, while eating out of the pan, rubs against the wick, greasing itself; you don't catch them. Put melted lard in the tank and feed in the pan, set pan in the yard among the chicks and see how quick it works, the chicken and wick come together and the vermin are killed. No. 1 machine, for 50 chicks, $\$ 1.25$. Postpaid, $\$ 1.35$.

\section{INCUBATOR AND BROODER}

\section{THERMOMETERS}

For use with any make incubator.

Tycos 5774 , standing kind, each_-_-_-_-_ 75 c postpaid Tycos 5770 , hanging kind, each-Tycos 5792, brooder thermometer, each---60c postpaid Cotton Lamp Wicks, all sizes, each 5c; doz., 50c. postpaid.

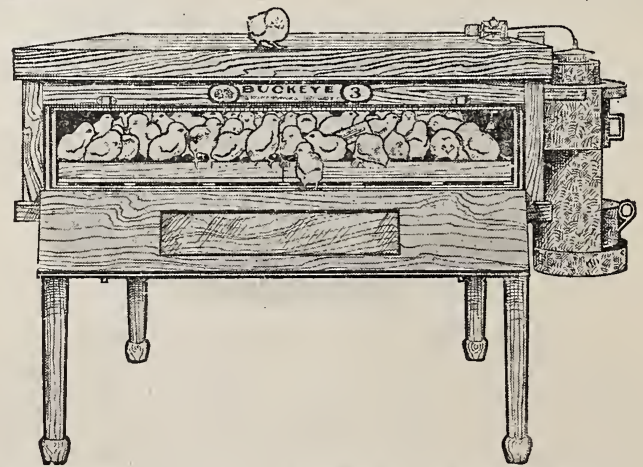



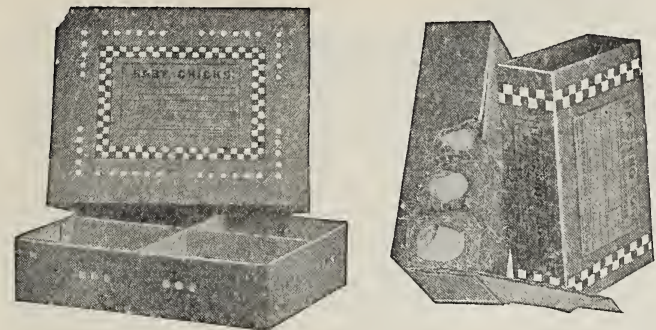

LIVE CHICK SHIPPING BOX

Made especially for shipping day-old chicks. Folded flat for shipping, but easily set up and made ready for use.

\begin{tabular}{rrrrrrr} 
& & \multicolumn{4}{c}{ Not past 3rd zone } \\
& & \multicolumn{3}{c}{ Express } & Parcel & post \\
& & \multicolumn{2}{c}{ Each.. } & Doz. & Each & Doz. \\
25-chick & size & $\ldots . . .$. & $\$ .20$ & $\$ 2.00$ & $\$ .30$ & $\$ 2.25$ \\
50 -chick & size &...... & .25 & 2.75 & .35 & 3.25 \\
100 -chick & size....... & .40 & 3.50 & .50 & 4.00
\end{tabular}

\section{EYRIE SHIPPING COOPS}

Light in weight, but strong and durable. Ends and sides heavy corrugated cardboard. Top and bottom wood.

No. B, 21x12x22 inches deep, each $\$ .90$

No. C, $21 \times 18 \times 22$ inches deep, each No. D, 21x24x22 inches deep, each
Prices f. o. b. Vicksburg.

1.10

ANDERSON HATCH-AN-EGG BOXES

This is the best shipping box on the market today for transporting value eg's for hatching.

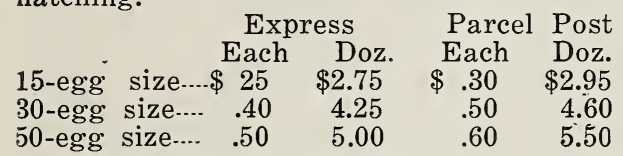

HUMPTY DUMPTY EGG CARRIER

One of the handiest egg carriers on the market. This carrier will hold 12 doz. egrs. Can be folded flat for shipment and is made of strong but light wooden slats fastened with strong steel wires. Very han.

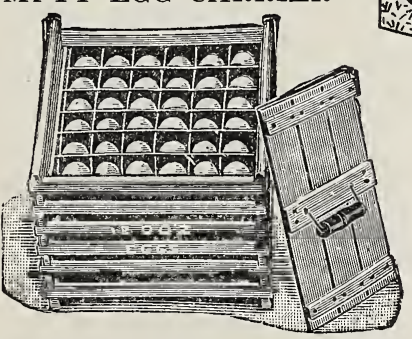
dy and something every poultryman should have. 3-doz. size, 60c; postpaid, 75c. 6-doz. size 70c; postpaid, 85c; 9-doz. size, 80c; postpaid, $\$ 1.00 ; 12$ doz. size, 90c; postpaid, $\$ 1.10$.

\section{THE "BABIE" CHICK FEEDER}

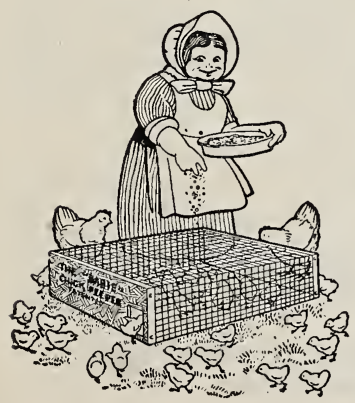

This simple wire feeder protects the little chicks and insures them plenty of feed, and will pay for itself many times over in economy of feed. It can be used to prevent mother hens from straying with their broods and also in connection with the Lawn Park Brood Coops. Price, $\$ 1.50$; postpaid, $\$ 1.70$.
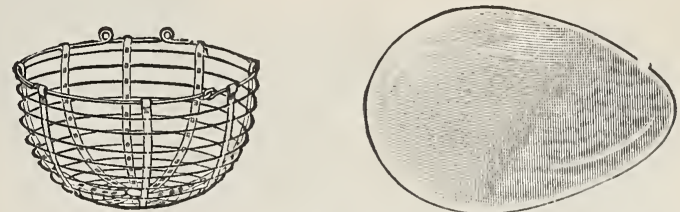

NEST EGGS

Knox Lice Medicate Nest Eggs-These eggs are a perfect imitation of the hen's egre, containing a powerful disinfectant, which keeps all lice, mites, etc., out of the nest and off the hen. Each, 8c; doz., 75c; postpaid: each, 15c; doz., 90c.

Lime Nest Eggs-Nonbreakable, Antiseptic. A perfect shape, making it a splendid and lasting accessory. Doz., 40c; postpaid, doz., 50c.

Porcelain-These are made of first class glass. They will not break easily and will last a lifetime. Doz., 40c; postpaid, doz., 55c.

\section{WIRE HEN'S NEST}

These nests are intended to be fastened with screws or screw hooks-if wanted removable. They afford no place for vermin and allow the air to circulate freely, advantages not obtained when wooden boxes are used. They are intended to be filled with straw, which can 'be readily removed. Each, 25c; doz., \$2.80. Postpaid, each, $40 \mathrm{c} ; 12$ for $\$ 3.10$, not past 3rd zone.

\section{IT TELESCOPES}

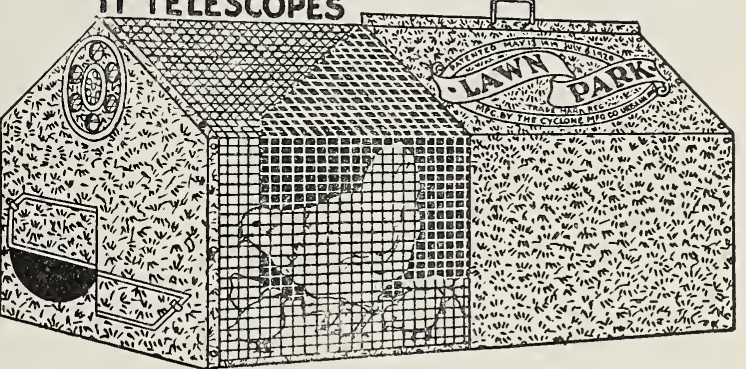

\section{THE LAWN PARK COOP}

Gives the chicks sunshine, fresh air, grass made to telescope, therefore affords chicks roving space, yet they are safe. Has removable bottom, makes cleaning easy; sanitary; keeps out lice and mites, and gives ample ventilation. Size coop, closed $18 \times 24$ inches. When open with park extended, $18 \times 48$ inches. Price, each, $\$ 4.00$, f. o. b., Vicksburg.

\section{RAX IS NOT A POISON}

While it is absolutely

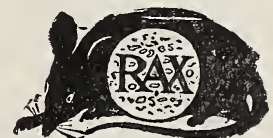
deadly to rats and mice, it is harmless to human bengs, domestic animals, poultry and birds. It may be used anywhere with complete safety.

\section{RATS TFAVP BFFORF TrFY DIF}

Within a few days after eating bait prepared with Rax. rats and mice become feverish and seek the open air where they die-outdoors.

\section{HOW TO USE RAX}

Add water to the bottle and shake contents until water is cloudy. Then moisten bait (bread, crackers or cheese) with the mixture and place it near the holes. Rax does not affect the taste of the bait.

Directions are furnished with each package. One bot tle is enough for an ordinary house; allow one bottle to each 500 feet of floor space in large barns, mills, etc. Price, 75 c per bottle, postpaid. 


\section{Poultry Feeds}

\section{RED COMB POULTRY FEEDS}

The extra quality feed contains no shell or grit to make weight; try it, and you will use no other. Composed of choice grains, seeds and charcoal. A clean, bright, balanced ration for general use. As a scratch feed it is unequaled. Made without grit or shells. 6 lbs., 25c; postpaid, 6 lbs., 40c.

\section{RED COMB COARSE CHICK FEED}

A developing food, composed of cracked grains and seed of the highest quality and especially adapted to the growing period, and when used insures a strong and rapid growth. This feed also contains charcoal. 5 lbs., 25c; postpaid, 5 lbs., 40c.

\section{RED COMB FINE CHICK FEED}

Composed of cracked grains, seeds and charcoal. Highly nutritious, easily digested and especially suited to the tender digestive organs of the little chicks. Made without grit. 5 lbs., 25 c; postpaid, 5 lbs., 40 c.

\section{RED COMB BABY CHICK MILK MASH}

A milk substitute. Made with the utmost care from dried milk, barley' meal, locust bean meal, bone meal, rice polish, flax seed meal, and a dozen other needful grains and herbs ground to the proper consistency. Red Comb Brand Poultry and Chick Feeds are always dependable. Don't fail to use the new Milk Mash on your chicks this spring. $1 \mathrm{lb}, 10 \mathrm{c} ; 4 \mathrm{lbs} ., 25 \mathrm{c}$; Postpaid, 1 lb., 20c; 4 lbs., $40 \mathrm{c}$.

\section{RED COMB GROWING MASH}

The best balanced feed for feeding growing chicks to produce growth. This is a new Red Comb product and is well worth a trial. 5 lbs., 25c; postpaid, 5 lbs., 40c.

\section{RED COMB MASH, WITH DRIED BUTTER- MILK}

This is the great egg producer. A mash feed prepared expressly for egg production, being very rich in egg-making elements. This mash is unsurpassed as a winter egg maker. It is the most wonderful feed in the world for making hens lay in cold weather. 5 lbs., 25c; postpaid, 5 lbs., 40c.

\section{CONKEY'S BUTTERMILK STARTING FOOD}

The history of poultry keeping records no triumph such as this wonderful chick food has had. The rich, pure, buttermilk is mixed with a combination of clean, wholesome grains, balanced just right for the sensative organs of the little chicks. The lactic acid keeps down yourself. By freight, 21/2 lbs., 25c; 5 lbs., 40c; 10 lbs., 70c; postpaid, 21/2 lbs., 35c; 5 lbs., 55c; 10 lbs., $95 \mathrm{c}$.

\section{O. K. POULTRY LITTER}

A perfect scratching material. Superior to straw, alfalfa meal, etc. A deodorizer, absorbent, disinfectant and labor-saving litter. It absorbs all the moisture from droppings. Will last for several months in your brooder or poultry house. Lice will not live in it, and therefore makes a splendid material for nests, being soft and pliable and keeps out all insects. Try $\mathrm{O}$. $\mathrm{K}$. Litter once and you will never be without it. Price, 18 lbs., $\$ 1.00 ; 50$ lbs., $\$ 2.00$; bale, about 160 lbs., $\$ 5.50$, f. o. b. Vicksburg.
GRANULATED BONE

Granulated Bone is made from fresh, green bone, from which the moisture and grease have been taken, leaving nothing but the phosphates, lime and nitrogenous matter. These are the only food properties of bone, green or dry, so when you buy granulated bone you will get it without paying freight on moisture or grease. This preparation will keep in any climate, in any dry place. It is especially valuable as an eggshell producer. Promotes strong, healthy growth of the bones in young chickens. Prevents leg weakness. Mix a little in soft feed. Coarse for hens, 3 lbs., 25c; 25 lbs., \$1.50; 100 lbs., $\$ 5.00$. Fine, for chicks, 3 lbs., 25c; 25 lbs., $\$ 1.50$; 100 lbs., \$5.00; postpaid, 3 lbs., 35c.

CHAMBERLAIN'S PERFECT CHICK FEED

The original dry feed for baby chicks, made without any corn, avoids bowel trouble and many other diseases caused by improper feed. Contains all the meat, bone, charcoal, grit, oat meal, etc., necessary for the successful raising of baby chicks, thus making it unnecessary to feed them anything else. 5 lbs., 25c; postpaid, 5 lbs., 40c.

\section{CHARCOAL}

If you want healthy chickens, rugged-growing stock with bright healthy plumage, birds that will fatten easily and well, and entire freedom from sour crops and indigestion with laying stock, feed Charcoal. This is an easy hint to take, and the coal is low in price. The per hen cost is so low as to be almost ridiculous, and yet it is one of the simplest and best helps to success. Keep it before them all the time, and also feed it in the mixed grain. Nothing equals it as a disease preventative. Made in 3 sizescoarse for hens; medium for pigeons; fine for baby chicks. Price, 2 lbs., 15c; 25 lbs., $\$ 1.25$; $50 \mathrm{lbs}$., $\$ 2.25 ; 100 \mathrm{lbs}$., $\$ 4.00$, postpaid, $2 \mathrm{lbs} ., 25 \mathrm{c}$.

\section{GROUND OYSTER SHELLS}

Every poultryman realizes the importance of crushed oyster shells as an egg-shell maker, and promoter of good health. Every pound of oyster shells offered by us is especially prepared for feeding poultry. They are crushed and ground to the size which expert poultrymen agree to be the best. Use oyster shell freely. It is good for chickens, old or young. Coarse, for hens, $10 \mathrm{lbs}$., $25 \mathrm{c}$; 50 lbs., 75c; 100 lbs., $\$ 1.25$. Fine, for chicks, 10 lbs., 25c; 50 lbs., 75c; 100 lbs., \$1.25. Postpaid, 10 lbs., $50 \mathrm{c}$, not past 3 rd zone.

\section{GRIT FOR POULTRY}

Grit is as essential for poultry as food, as without it they cannot digest the food. Poultry will starve to death with full crop for no other reason than they have no teeth with which o grind the food into proper consistency. Grit should be fed in hoppers or boxes. Hen size, 10 lbs., $25 \mathrm{c} ; 50$ lbs., $\$ 1.00 ; 100$ lbs., $\$ 1.75$. Chick size, $10 \mathrm{lbs}$., 25c; $50 \mathrm{lbs}_{*} \$ 1.00 ; 100 \mathrm{lbs}$., $\$ 1.75$. Postpaid, 10 lbs., $50 \mathrm{c}$, not past $3 \mathrm{rd}$ zone.

\section{ALFALFA CLOVER MEAL}

It is an acknowledged fact that green food is one of the most important foods necessary to heavy egg production. Among those who are unable to obtain a plentiful supply of green stuff, Alfalfa Meal should fill a longfelt want, it being an excellent substitution and a very nutritious food, which, when mixed with the mash, also affords bulk to concentrated foods. $50 \mathrm{lbs}$., $\$ 1.50 ; 100$ lbs., $\$ 2.50$.

\section{DARLING'S MEAT SCRAPS}

For success with poultry it is absolutely necessary to give them plenty of animal food in the winter, to take the place of insects, etc., which they get during the summer. Feed mixed with meal or bran, at the rate of $1 / 4 \mathrm{lb}$. beef scraps per day to a dozen hens. $3 \mathrm{lbs}$., 25c; 25 lbs., $\$ 1.50$; 50 lbs., $\$ 2.85 ; 100$ lbs., $\$ 5.50$. Postpaid, 3 lbs., $35 \mathrm{c}$.

All Prices Subject to Change Without Notice and F. O. B. Vicksburg except as noted. See Page 50 for Prices on Redcomb Feeds in Large Quantities. 


\section{ORDER SHEET \\ VICKSBURG SEED CO. VICKSBURG, MISS.}

Date.

Enclosed find

State whether check, draft, money-order or stamps.

for $\$$ in payment or order written below.

\section{Name}

Post Office

R. F. D.

County

State.

\section{Shipping Point if different}

Forward By

State on this line whether we are to send by Express, Freight or Parcel Post.
Please Do Not Write In These Spaces

We do not warrant in any way, express or implied, the contents, or the description, purity, productiveness, or any other matter of any seeds. buibs or plants, sold by us, and we will not be in any way responsible for the crop. If the purchaser does not accept those goods on the above terms, no sale is made thereof, and he must return them at once, and money will be refunded. Subject to the above conditions we make this sale at the moderate prices we charge.

\begin{tabular}{l|c|c|c|c|}
\hline \hline QUANTITY & NAME OF ARTICLE WANTED & \multicolumn{2}{|c|}{ PRICE } \\
\hline \hline & & & & \\
\hline & & & & \\
\hline
\end{tabular}




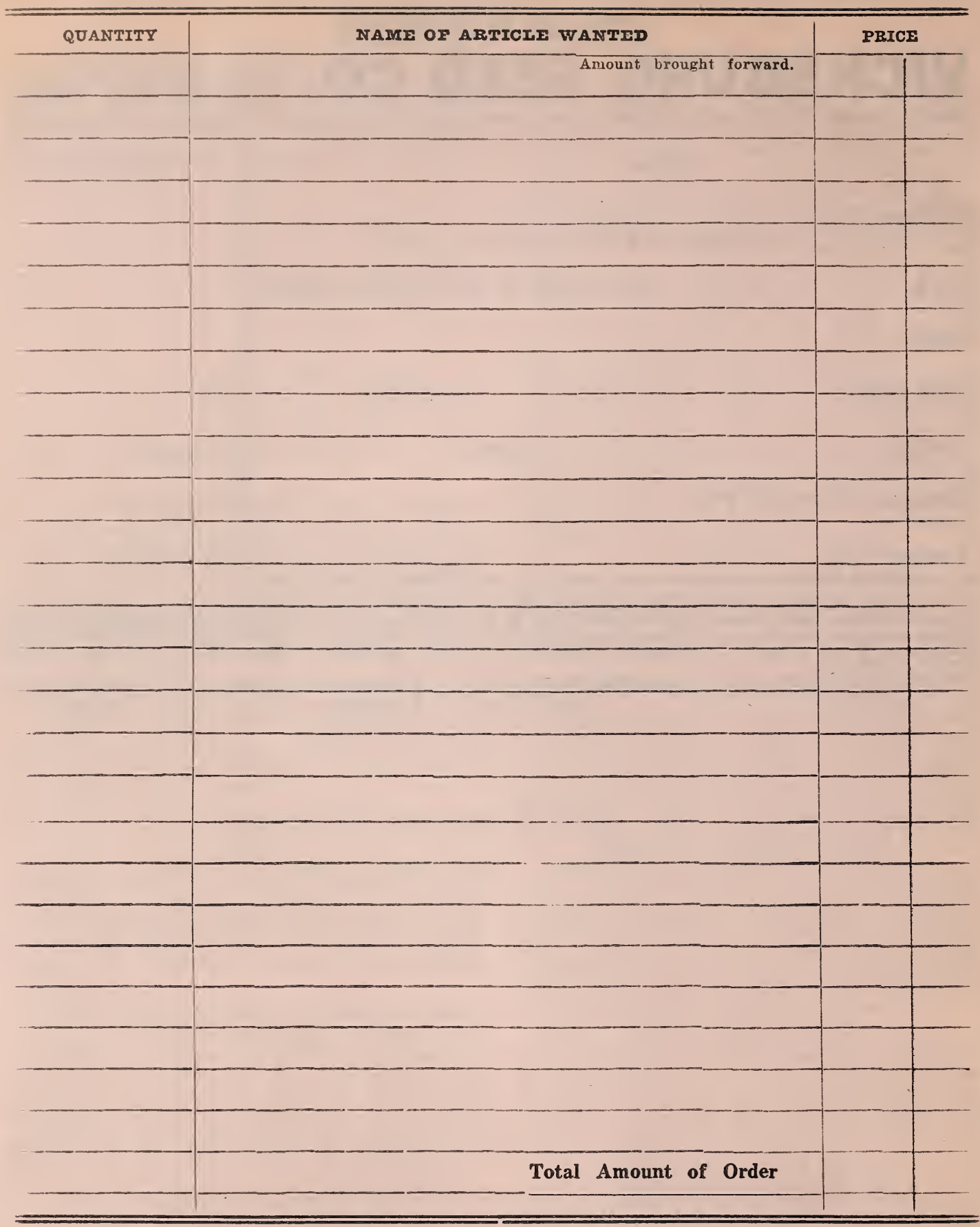

HAVE YOU FRIENDS OR NEIGHBORS INTERESTED IN BETTER FIELD, VEGETABLE AND FLOWER SEEDS? If so, please write their names below and we will include with your order for seeds FREE FLOWER SEEDS.

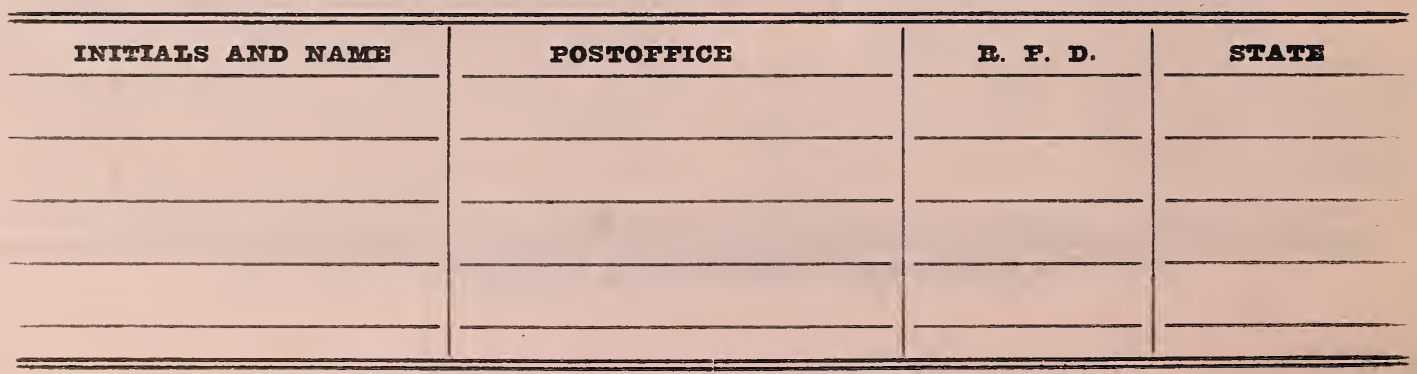




\section{FROST-PROOF CABBAGE PLANTS}

There are a number of islands on the Coast of Louisiana where the soil and climate conditions are just suited for growing tough, hardy cabbage plants during tlie Winter and early Spring. The plants make a slow but steady growth, uint at eight. to ten weeks of age they are very tough and hardy, the buds are purple and the outer leaves a reddish brown. When in this condition they can be shipped to territory further north and be planted ir the open ground a month to six week sooner than the home-grown hotbed or colc frame plants.

Plants usually withstand the cold winter, say at least six winters out oi 8 in Texas, Louisiana, Mississippi and Alabama, In other territories, February and bama. In other months to plant. The word March are best months to plant. The word, "frost-proof" does not mean "freeze-proof." amount of freezing weather the plants will temperature of 20 degrees above zero with sleet and snow seldom hurts them.

The top of the plant does not grow until your regular Spring weather opens up, but the roots grow from the time they are planted, and just as soon as Spring the time they arts, the established root growth assimilates weather starts, the established root growth assimilates maturing headed cabbage two to three weeks sooner than you can mature them from hotbed and cold frame plants.

r'o get the advantage of these frost-proof cabbage , laits they must be planted a month or six weeks earlier than you would plant home-grown plants. We fill orders from January 15 th to May 1 st.

The plants when received will be somewhat wilted and have a hard stunted appearance, which will be dispppointing to persons who have never used the plants bepointing to persons who have never used the plants becrop results.

Will have the following varieties:

Early Jersey Wakefield. Early Flat Dutcl

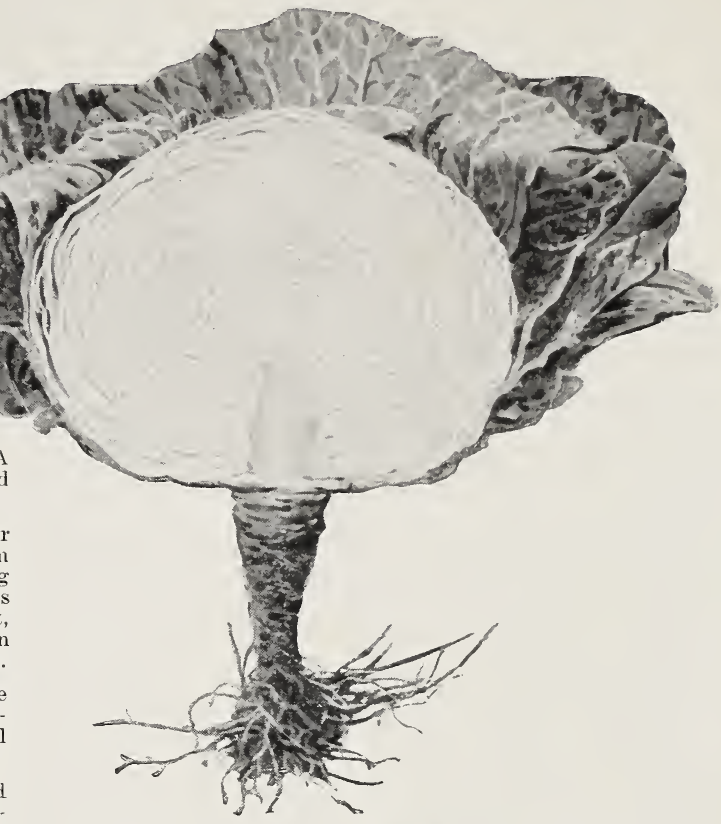

Charleston or Large Wakefield and Succession.

Prices, by parcel post, $100^{\circ}$ for $50 \mathrm{c}$; 500 fir $\$ 1.75$. 1000 for $\$ 3.00$. No orders filled for less the n 100 plents of a variety. By express. not prepaid, 100 ior $40 \mathrm{c}$; 500 for $\$ 1.25 ; 1000$ for $\$ 2.25$.

\section{VEGETABLE PLANTS}

\section{HOME-GROWN CABBAGE PLANTS}

These are ready about the first part of March; they should not be set out earlier, being tender they are no as hardy as the frost-proof kind.

We can furnish the following varieties: Jersey Wakefield, Early Flat Dutch, Charleston Wakefield, Succession.

Prices: Parcel post paid-100, 50c; 500, \$1 75 ; $1,000, \$ 3.00$. By Express, not prepaid-100, $40 \mathrm{c}$; $500, \$ 1.50 ; 1,000, \$ 2.75$.

\section{BEET PLANTS}

Ready about March 1st.

Varieties-Crosby's Egyptian and Crimson Globe.

Prices: Parcel post paid-100, 55c; 500, $\$ 200 ; 1000$ $\$ 3.35$. By Express, not prepaid-160, 40c; 500, $\$ 1.75$; $1,000, \$ 3.00$.

\section{CAULIFLOWER PLANTS}

Ready March 1st.

Varieties-Early Snowball and Dry Weather.

Prices: By parcel post-Doz., 25c; 50, 90c; 100 $\$ 1.50$. By Express, not prepaic-Doz., 20c; $50,75 \mathrm{c}$ $100, \$ 1.25$.

\section{CELERY PLANTS}

Ready April 1st.

Varieties-Golden Self-Blanching and Henderson's White Plume.

Prices: By parcel post-Doz., 25c; 50. 45c; 100 75 c. By Express, not prepaid-Doz., 20c; 50, 35c; 100 $60 \mathrm{c} ; 500, \$ 2.00$

\section{EGG PLANTS}

These are ready about Avril 20 th.

Varieties-Black Deauty, N. Y. Improved Purple.

Prices: Prrcel post paid-no 3.5c; 50. 90 : 100 $\$ 1.50$. By Express, not prepaid-5oz., 25c; 50, 75c ino. $\$ 1.25$

\section{LETTUCE PLANTS}

Ready March 1 st.

Varieties-Big Boston, New York or Wonderful.

Prices: Parcel post paid-50, 35c; $100,55 \mathrm{c} ; 500$ $\$ 2.00$. By Express, not prepaid-50, 25c; $100,45 \mathrm{c}$ $500, \$ 1.75 ; 1,000, \$ 3.00$.

\section{PEPPER PLANTS}

Ready April 15th.

Varieties-Chinese Giant, Ruby King, Long Cayenne. Prices: Parrel Post pair-Doz, 35c; 50 0uc: 100 $\$ 1.50$. By Express, not prepaid-Doz., 25e; 50, 75 $100, \$ 1.25$

\section{TOMATO PLANTS}

These are ready about the 20 th of March. Our stock is raised from the very best quality of seed and will rive perfect satisfacticn.

Varietics-Gulf State Market, Ponderosa, Norton Wilt Resistant, Early Detroit, Globe, Stone.

Prices Hot Bed or Seedling Stock: Parcel Post paid -Doz., 25c; 100,75c; 500, \$3.50. By express, not pre paid-Doz., $15 \mathrm{c} ; 100,60 \mathrm{c} ; 500, \$ 2.00$.

Prices Transplanted Stock: Parcel Post paid-Doz $35 \mathrm{c} ; 50,90 \mathrm{c} ; 100, \$ 1.50$. By Express, not prepaidDoz., 25c; $50,75 \mathrm{c} ; 100, \$ 1.25 ; 1,000, \$ 10.00$.

\section{SWEET POTA'TO SLIPS}

Varieties-Certified Nancy Hall and Porto Rico.

Prices Certified Slips: 500, $\$ 2.00 ; 1,000, \$ 3.75 . \% \mathrm{No}$ orders filled for less than 500 certified plants. All shipments will be made from our nearest growers. By, express only in state of Mississippi. Into other states if wanted by parcel post, prices: 100 for $50 \mathrm{c} ; 500$ for $\$ 2.25$; 1,000 for $\$ 4.00$, postpaid.

Prices on potato slips subject to change without notice. 
